Fraukadams

The Bancroft Library

University of California - Berkeley 
Digitized by the Internet Archive in 2007 with funding from Microsoft Corporation 


\title{
THE CITIZEN'S LIBRARY
}

\section{OF \\ ECONOMICS, POLITICS, AND SOCIOLOGY}

\author{
EDITED BY \\ RICHARD T. ELY, Ph.D., LL.D. \\ DIRECTOR OF THE SCHOOL OF ECONOMICS AND \\ POLITICAL SCIENCE, UNIVERSITY OF \\ WISCONSIN
}

IRRIGATION INSTITUTIONS 


\section{THE CITIZEN'S LIBRARY OF ECONOMICS, POLITICS, AND SOCIOLOGY. \\ I 2mo. Half leather. \$1.25 net each.}

MONOPOLIES AND TRUSTS.

By Richard T. Ely, Ph.D., LL.D.

THE ECONOMICS OF DISTRIBUTION.

By JoHN A. HoBson.

WORLD POLITICS.

By Paul S. Reinsch, Ph.D., LL.B.

ECONOMIC CRISES.

By Edward D. Jones, Ph.D.

OUTLINE OF ECONOMICS.

By Richard T. Ely.

GOVERNMENT IN SWITZERLAND.

By John Martin Vincent, Ph.D.

ESSAYS IN THE MONETARY HISTORY OF THE UNITED STATES.

By Charles J. Bullock, Ph.D.

SOCIAL CONTROL.

By Edward A. Ross, Ph.D.

HISTORY OF POLITICAL PARTIES IN THE UNITED STATES.

By Jesse Macy, LL.D.

MUNICIPAL ENGINEERING AND SANITATION.

By M. N. Baker, Ph.B.

DEMOCRACY AND SOCIAL ETHICS.

By JaNe Addams.

COLONIAL GOVERNMENT.

By Paul S. Reinsch, Ph.D., LL.B.

MUNICIPAL SOCIOLOGY.

By Charles Zueblin.

IN PREPARATION.

CUSTOM AND COMPETITION.

By Richard T. Ely, Ph.D., LL.D.

THE MACMILLAN COMPANY, 66 Fifth Avenue. 


\section{Irrigation Institutions}

A DISCUSSION OF THE ECONOMIC AND LEGAL QUESTIONS CREATED BY THE GROWTH OF IRRIGATED AGRICULTURE IN THE WEST

BY

ELWOOD MEAD, C.E., M.S.

Chief of Irrigation Investigations, United States Department of Agriculture; Professor of Institutions and Practice of Irrigation in the

University of California; and Special Lecturer on Irrigation Engineering in Harvard University

\section{Xrew 想ark \\ THE MACMILLAN COMPANY \\ LONDON : MACMILLAN \& CO., LTD. 1903}

All rigbts reserved 
Copyright, Ig03,

By THE MACMILLAN COMPANY.

Set up and electrotyped January, 1903.

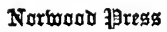

J. 8. Cushing \& Co. - Berwick \& Smith Norwood Mass. U.S.A. 


\section{PREFACE}

THIs work is based on twenty years' experience in the development of irrigated agriculture in the arid West. Fifteen years of this time were devoted to the study and administration of irrigation laws as assistant State engineer of one commonwealth and territorial and State engineer of another. The duties of these positions brought the writer into personal and official relations with all classes of men to whom the problems of irrigation were of vital interest. These included not only farmers, ditch builders, and investors in irrigation securities, but also legislators and jurists who were shaping the legal principles which are to control the distribution and use of Western water-supplies, and the social and economic fabric under which unnumbered millions of people must dwell.

All phases of the subject had to be dealt with. The plans for canals to carry water far over the thirsty plains had to be passed upon; advice had to be given regarding the best methods of applying water to the land and the amounts required to bring crops to maturity: The problems of cooperation and organization, inseparably connected with irrigated agriculture, had to be studied. Head-gates had to be closed in times of scarcity, 


\section{PREFACE}

in order that other users of water should receive their just share of the common supply.

The lesson of these years is that the vital agricultural problem of the arid West is to establish just and stable titles to water and provide for their efficient protection in times of need. Every farmer in this region comes to understand the overshadowing importance of water. Their farms extend along many rivers for scores and even hundreds of miles. Every irrigator from a stream is bound to his fellow-irrigators by their common tie of dependence upon it. The amount diverted by one ditch is a matter of concern to all other ditches below, because it affects the volume remaining for their use. The independent life of the farmer in humid lands is impossible $\lambda$ Irrigated agriculture is an organized industry, and the prosperity and happiness of those engaged in it are largely determined by the character of its institutions.

The changes wrought by irrigation in the last half century have been little less than marvellous. The highest-priced farming lands on this continent are found in areas once regarded as desert and worthless, and great cities have been reared in regions it was once believed would always be dreary solitudes. In some sections material development has outrun the creation of institutions needed to insure enduring success. Irrigation laws are so ambiguous or contradictory that the finite intellect is not able to interpret their meaning. The water rights which govern the value of 


\section{P REFACE}

farms have many forms and are acquired by many methods. In one respect, however, they are all aliké ; no matter whether acquired by compliance with a statute or by purchase from a ditch company, they are a source of more perplexity at the outset and of more anxious thoughts afterward than are all the other questions of irrigation combined. The irrigator whose water right does not furnish grounds for either an inquiry or a grievance is a rare exception.

Nor are irrigators alone in finding the issues created by the use of streams hard to define. Lawmakers and courts have found them equally perplexing. They involve the determination of the kind of ownership which shall be recognized in the rains and snows which are gathered together in rivers, in order that each user shall receive his proper share and monopolies in water be prevented.

Although the field for the study of the engineering and agricultural problems of irrigation is a broad and inviting one, its problems are not so urgent as those which relate to the ownership and distribution of the water-supply. Neither is there any other issue about which irrigators are so greatly concerned.

The problems of irrigation are not, however, of water alone, but of land and water. In many parts of the arid West ability to control the use of contiguous grazing lands is absolutely necessary to the success of irrigation, since farming can only be carried on with profit in connection with growing live stock. Among farmers so situated, range 
rights are almost as important as water rights, but under existing laws no such rights on the public domain can be maintained except by force.

The opening years of the twentieth century have brought a larger and truer conception of the value of the arid West and of the part it is to play in the industrial life of this nation. It is now realized that its valleys are in time to be the homes of many millions of people, and that under just and wise policies it is possible to create homes which will represent a higher average of human comfort and better social and industrial conditions than can be found elsewhere save in few places on the globe. The interest of the nation has been awakened to the opportunities here presented, and the civic pride of Western communities has been aroused to secure the creation of irrigation codes which will be worthy of a self-governing people. As an aid to local effort, the general government is engaged in gathering facts on which future developments should be based. The Department of the Interior is measuring the water-supply, and finding out where it can be used to the best advantage and with the largest return. The Department of Agriculture is studying the methods of distributing and using water in order to promote its more skilful and effective use, and is inquiring into the social and legal questions created by the use of streams in irrigation, both in this country and in other lands. From its beginning the writer has been in charge of the latter investigation. It is hoped that what is here written will be an influ- 


\section{P REFACE}

ence for good. The convictions expressed have been more largely shaped by what has been seen than by what has been read. They are the result of careful study, having at its foundation an abiding faith in the future importance of the arid West, a pride in the success already won, a belief in the future greatness of the regions most concerned, and a profound sympathy for the pioneers in the development of these regions, in the perplexities and uncertainties which have beset them.

This work was originally prepared for a course of lectures on the Institutions and Practice of Irrigation in the University of California. In their preparation, the irrigation bulletins of the Office of Experiment Stations were freely drawn upon. Dr. A. C. True, director, and Mr. R. P. Teele, Editorial assistant, have rendered valuable assistance in this connection, which is here gratefully acknowledged. The writings of Colonel E. S. Nettleton and Mr. William E. Smythe have been full of suggestions, and Mr. C. T. Johnston, Professor J. M. Wilson, Hon. J. E. Field, Mr. W. H. Code, Hon. D. W. Ross, Professor S. Fortier, Mr. Frank Adams, Hon. J. S. Greene, and Hon. Adna Dobson are among those to whom the writer is indebted for information. 



\section{CONTENTS}

PAGE

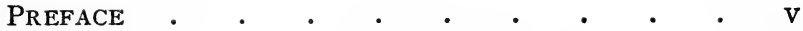

CHAPTER

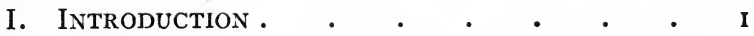

II. Land Laws of the ARID Region • • I3

III. The Beginnings of IRRigation • • • $4 \mathrm{I}$

IV. THE DOCTRINe OF APPROPRIATION • . 60

V. Contract Water Rights • • • 88

Vi. Measurement of Water . • • . 100

VII. The Duty of Water • • • • • I 6

VIII. IRRIGATION IN COLORADO • • • • 143

IX. IRrigation in California • • • • I80

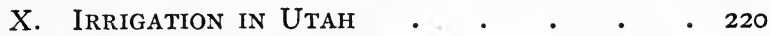

XI. IRrigation IN Wyoming • • • • 247

XII. Irrigation in the Other Arid and Semi-

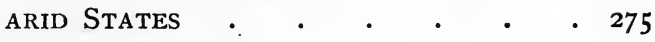

XIII. Riparian aND INTERstate Rights • • 319

XIV. Methods AND Measures NeEded FOR FUTURE DEVElopment • • • • • • 344 



\section{IRRIGATION INSTITUTIONS}

\section{CHAPTER I \\ INTRODUCTION}

ThE arid region of the United States is destined in the near future to have a large place in national affairs. This is due in part to the value of its unused resources and in part to the need of their development.

Our population has been doubling with each quarter of a century, and, while there will hardly be so rapid an increase in the future, the prediction seems safe that by the end of another fifty years we shall have in this country over $200,000,000$ people to feed and clothe. We have a significant warning of what is before us in the present shortage and resulting high price of beef. Statistics show that there are now $10,000,000$ fewer cattle in the United States than there were ten years ago, and in that time the number of people to be fed has increased 10,000,000.

Up to the present, the vacant fertile districts of the humid States have been chiefly relied upon to meet the demands of the nation's growth. They have supplied homes for our increasing agricultural 
population, and replaced lands rendered unproductive by erosion and impoverished by wasteful methods of culture. We have now, however, reached the limits of such expansion. More cultivated land must be provided, or better use made of that now occupied. In both directions the uninhabited and mismanaged areas of the arid region are full of opportunities.

A realization of the possibilities of this region and of what man can accomplish by a right use of its resources has been of slow growth. To the early fur traders and explorers the arid region was a dreary, worthless waste. To neither Bonneville, Fremont, nor any of the multitude who crossed its vast expanse to reach the golden rivers of California was there given any prophetic vision of the magic to be wrought by irrigation. Nor is this surprising. It is difficult to imagine anything less attractive than the stretches of barren sand broken only by the isolated yuccas of the Mojave Desert, or anything more dreary than the crucifixion thorn of Arizona. Only in localities where the work of reclamation has been in progress long enough to permit the growth of trees, flowers, and shrubs can the possibilities of the soil and climate be appreciated. No greater contrast can be found anywhere than is afforded by a comparison of the desert above ditches and the cultivated fields below them. Perhaps one of the most striking illustrations of this is to be found in the Salt River Valley, Arizona. Here, after a long and tiresome journey 
through a desolate and apparently worthless region, the traveller suddenly finds himself confronted by homes rivalling in taste and convenience those of the Eastern States, and surrounded by orchards and gardens which resemble the century-old creations of France and Italy more than the development of the past twenty years.

The arid West is the nation's farm. It contains all that is left of the public domain, and is the chief hope of those who dream of enjoying landed independence, but who have little beside industry and self-denial with which to secure it. As it is now, this land has little value. This is not because the land lacks fertility, but because it lacks moisture. Where rivers have been turned from their courses the products which have resulted equal in excellence and amount those of the most favored district of ample rainfall.

After this brief statement of the economic importance and possibilities of American irrigation, it is interesting to consider the physical conditions which are to govern its development and see amid what surroundings so large a future population must dwell, and what are the resources upon which it will rear its economic edifice.

The climate of the western half of the United States finds its chief characteristic in its aridity or dryness. The heat of the Southern summers and the cold of the Northern winters are alike tempered and mitigated by this aridity. The arid region knows neither the humid heat which prostrates 
nor the humid cold which penetrates. Its mountain valleys are recognized natural sanitaria to which thousands of persons must go each year in order to live.

The dominant feature of its topography is the mountains. On every hand a rugged horizon meets the view. From north to south - from Canada to Mexico - the Rocky Mountain range forms the backbone of the continent. Far to the west and parallel with the Rocky Mountains the Sierra Nevada and Cascade ranges lift their barriers to intercept the passing moisture from the Pacific Ocean and condense it into snow. Between these principal chains are many connecting ranges and outlying spurs which make of that region a succession of mountains and valleys, of forests and deserts. Down these mountains course raging torrents which unite to form the sinuous rivers that wind across the lonesome plains finally to sink into the sands or make their difficult way to the distant ocean.

West of the Rocky Mountain range the lands capable of cultivation lie in the valleys, rising with gradual slope on either side of the streams to meet the foothills. Some of these valleys are narrow, and the tillable lands will accommodate only hundreds. Along other streams the areas are more extensive and will support thousands or tens of thousands, and along a few, like the Snake, the Yellowstone, and the Sacramento, millions may dwell. East of the Rocky Mountains there is, in 


\section{INTRODUCTION}

addition to the slopes toward the streams, a general slope extending for hundreds of miles from the base of the range toward the Missouri and Mississippi rivers. All of this land is fertile, the greater part of it adapted to the distribution of water, and the area which can be reclaimed is limited only by the water-supply.

If every drop of water which falls on the mountain summits could be utilized, it is not likely that more than ten per cent of the total area of the arid West could be irrigated, and it is certain that, because of physical obstacles, it will never be possible to get water to even this small percentage. As an illustration of what is meant by this it may be stated that the Columbia River is from three hundred to fifteen hundred feet below the surface of the bordering arid table-land in northeastern Washington. It would be impracticable to raise its water to the lands requiring irrigation. Throughout a large part of its course in Montana and the Dakotas, the Missouri River flows in a deep channel, and as it falls only two or three feet per mile, the elevation of its water to the level of the land which might be irrigated is at present practically impossible, because the work necessary for such utilization will cost more than the land and the water are worth.

Back of the irrigated lands are millions of acres of exceptionally fertile land which can neither be irrigated nor cultivated without irrigation. Some of it cannot be irrigated because the surface is too 


\section{IRRIGATION INSTITUTIONS}

broken for the distribution of water. The bad lands of Dakota and Montana, the lands overflowed with lava in Idaho, and the broken ridges which border the Snake and the Columbia in Washington are illustrations. On the other hand, there are millions and millions of acres with slopes so gentle and uniform that nature seems to have designed the land for the furrows and fields of the irrigated farm. It will never be farmed, however, because water is lacking. Many whose enthusiasm outruns their judgment are inclined to believe that these attractive possibilities will in time be realized in some now unknown way. The benefits which would come from this have given rise to theories of rivers flowing beneath the surface where science is unable to find a source for such a water-supply. Any one who considers the matter carefully realizes that the domain of irrigation is restricted within narrow limits, and that only calamity can come from trying to extend the limits of settlement beyond the possibilities of the known and assured water-supply. Only a small portion of the lands of the West suited to irrigation can be watered, but must always remain grazing lands, having less agricultural value than they possess to-day unless measures are taken for their proper management.

The scanty but nutritious grasses which the dry climate of the arid West causes to cure perfectly furnish, winter and summer, all the food required by millions of live stock, and this pasturage has been a dominant factor in the settlement of many 
of the arid commonwealths. The grazing lands have, therefore, in the aggregate great productive value, and this, joined to the fact that they are many times the area of the lands which can be irrigated, renders their management an important factor in irrigation development.

The lowest lands irrigated are in the Salton Desert, near the mouth of the Colorado River, I 50 feet below sea-level. On the head of this river in Wyoming grain ripens a mile and a half above sea-level. The mountain barriers and differences in elevation have, in many cases, counteracted the influence of latitude and given a diversity to production, which must be taken into account in forecasting the agricultural future of this region and in providing for its development. On the Pacific coast the Sierras, acting with the Japan current, temper the climate of California so that oranges ripen at Oroville, nearly 200 miles north of San Francisco, as surely as at San Diego, 500 miles south. Black Hamburg grapes are grown in the open air in Washington less than 200 miles south of the Canadian border. On the other hand, in the high plateaus bordering the Rocky Mountains, there are many irrigable valleys subject to frost every month in the year, where nothing can be grown but native hay and a few of the hardier grains and vegetables. The value of water in irrigation depends upon what can be grown with it, as does the amount of money which can profitably be expended in building ditches and reser- 


\section{IRRIGATION INSTITUTIONS}

voirs. Where an acre-foot of water produces a crop worth over $\$ 100$, as was the case last year in California, irrigators can afford to make a large outlay for a water-supply. In some sections of the arid region a right to an inch of water sells for $\$ 1000$; in other sections, for $\$ 5$. In Southern California an orange grove of twenty acres constitutes an estate. It brings a larger return than is derived from the products of a section of irrigated land in less-favored localities.

Another factor which influences the area which can be reclaimed is the fluctuation in the flow of streams. In the North their flow, as a rule, is perennial, the discharge being well maintained throughout the irrigation period. Here irrigators give most thought to the construction of canals and ditches. In the southern half of the arid region, streams are torrential in character. They carry the bulk of their discharge in sudden floods. The days when the channels are filled to overflowing are followed by weeks when they are empty or nearly so. To meet the needs of irrigation, the flow of these streams has to be equalized. For this, reservoirs are a necessity, and the problems of storage are of vital importance. The Wichita, the Pecos, the Rio Grande, and the streams of Southern California are illustrations of valleys where storage is the dominant factor in agricultural development.

In some sections these reservoirs must be built in the channels of running streams which carry 


\section{INTRODUCTION}

large quantities of sediment, many samples taken carrying from five to twenty per cent of solid matter. A doubt exists as to whether they may not fill so rapidly as to end their usefulness within a brief period. No reservoir filled with water so heavily laden with sediment can be perpetually maintained without some means of sluicing out the silt deposited. It will not do to establish homes and create communities under reservoirs which will in time become simply deposits of mud. This danger does not menace storage works in the northern part of the arid region. The waters of Snake River have emptied into Jackson Lake for centuries without filling it up; Yellowstone Lake is a natural reservoir of the Yellowstone River, and has been for untold ages, yet the sediment deposited has not materially diminished its size, and hundreds of similar illustrations might be added.

The importance of irrigation in the arid region is not to be measured solely by the value of the crops grown, but as well by the influence a home-grown food-supply will exert on the growth and prosperity of other industries. It must be kept in mind that, while many of the irrigated areas are small, they are the nuclei around which cluster the industries of vast outlying districts. They furnish the hay, grain, and vegetables for the mining camp, and are an insurance against destructive losses of range live stock in winter. Without irrigation, the region which separates the humid sections of the Atlantic and Pacific coasts would be a far more disagreeable 
and effective barrier to trade and commerce than it is to-day.

To the mines of this region must be added the forests which clothe the mountain sides, especially those of the North and Northwest. There the mountains are to a large extent made up of ground that is still virgin, trodden only by the hunter or the adventurous explorer.

The mountain streams furnish rare opportunities for the development of water-power. The Shoshone Falls in Idaho are but little inferior to those of Niagara, and the hundreds of streams which fall from the 10,000-foot level of the Rocky Mountain range to the 4,000-foot or 5,000-foot level of the plains at their base, are destined to turn more wheels of industry than have yet been harnessed east or west of the Mississippi River.

In order to estimate rightly the value of the irrigated farms of the arid West, we must take into consideration their environment. They have back of them the mine, the furnace, and the factory. They are surrounded and supplemented by valuable grazing areas. Western America is not only the country's storehouse of gold and silver, but it also contains immense deposits of copper, coal, oil, and iron, and cannot fail to have a prosperous and varied industrial life. Here there can be no onesided development, no community exclusively devoted to the production of corn, wheat, or cotton, to manufacturing, or to commerce. The farm, the stock ranch, the lumber camp, the mine, the factory, 


\section{INTRODUCTION}

and the store are destined to grow up and to flourish side by side, each drawing support from and furnishing sustenance to the others.

The importance of irrigation is now realized in the West as never before, and the best elements of citizenship are endeavoring to remove the obstacles which have heretofore hampered both public and private enterprise. The East, as a whole, is beginning to realize the great part which the West is to have in the events of the twentieth century. Worldwide forces are working to hasten the day of its complete development, and of the utilization of all of its rich resources.

The essence of the problem to be met at the outset is the control and distribution of the watersupply, since not only the enduring prosperity but the very existence of the homes created will be conditioned upon the ability to use the rivers of the region for irrigation. The diverse interests of individuals and communities, and even of different states, will all depend on streams flowing from a common source. To reclaim all the land possible will involve the spreading of water over a surface as large as New England with New York added. Standing now near the beginning of things and looking down the vista of the future, we can see in the courses of these rivers the dim outline of a mighty civilization, blessed with peace and crowned with a remarkable degree of prosperity, in case wise laws and just policies shall prevail in the years of the immediate future, while institutions are forming. 


\section{IRRIGATION INSTITUTIONS}

But if it be otherwise, - if greed and ignorance are allowed to govern, and we ignore the experience of older countries than ours, - there will remain to us only a gloomy forecast of legal, economic, and, possibly, civic strife. 


\section{CHAPTER II}

\section{Land Laws of the ARID Region}

ThE United States has been the largest landowner on earth. The General Land Office has administered the greatest domain ever drawn together under one control. Exclusive of Alaska and the recently acquired insular possessions, the public lands, sold and unsold, amount to about I,44I,436, I60 acres. Of this, over $100,000,000$ acres were given away in the form of bounties for military services; nearly 65,000,000 acres passed into private ownership under the swamp land law ; over $140,000,000$ acres were donated to railroads; over $105,000,000$ acres were given to the States for educational and other purposes. There remain unsold 546, I I 3,468 acres, practically all of which is in the arid region. The remainder has passed directly from the general government into private ownership, either under some of the agricultural land laws or under the different mineral, timber, or stone acts.

In the early days of the nation the public lands were valued chiefly for what they would bring. They were an asset to be sold in whatever way would bring the quickest and largest returns. No one could buy less than 640 acres; but the only 
maximum limit was his ability to pay. The first plan for the disposal of the public lands was prepared by Alexander Hamilton in 1790 . He recommended the selling of large tracts to men of wealth and associations, and the setting aside of tracts, not to exceed 100 acres each, for actual settlers. In I 800320 acres was made the unit of segregation in the eastern part of the domain and 640 acres farther west. Fourteen years later Albert Gallatin, in describing the public land system, says all public lands not otherwise provided for were offered for sale in I60-acre tracts. A law passed in 1820 cut this in two by permitting sales of 80 acres.

Early in the nineteenth century it began to be realized that the public domain was worth more as a means of providing homes than for its contributions to the running expenses of the government, and changes were made which would favor its disposal in tracts suited in size to the needs of a settler and his family. The Preëmption Law, which took its final form in I84I, fixed this area at 160 acres, and this was followed when the Homestead Law was passed in I862. This unit worked well in the disposal of the fertile domain of the Northwest and the Mississippi Valley; but when the wave of settlement which peopled this region had reached the arid slopes which border the eastern base of the Rocky Mountains, it was found to be a misfit. Here crops could not be grown by the aid of rainfall alone, and only a small fraction of the 


\section{LAND LAWS OF THE ARID REGION}

land could be irrigated. One hundred and sixty acres as a farm unit was an economic success in the settlement of Iowa; but it was ridiculous in Arizona, because a whole township would not support a settler if compelled to cultivate it in its natural state. A land unit not in harmony with climatic conditions placed an obstacle in the way of natural development, and a majority of the pioneers gave up trying to own or improve the land they used. They found it more profitable to become range stockmen and to leave the land in the possession of the government, while they pastured it without rental or restriction.

The experience of the United States in extending humid land laws to an arid region had its counterpart in the attempt of Texas to apply an arid land law to a humid region. When Texas became' a republic, it inherited its land system from Mexico, an arid country. This law made a homestead 4470 acres, or nearly 28 times the homestead of the Ohio Valley. It is an interesting fact that the productive capacity of one acre of land in Ohio or Iowa is about as many times that of an acre of grazing land in western Texas, where it requires from 20 to 30 acres to support a single steer. This law, when applied to the region for which it was framed, worked well; but when it was extended to the fertile valley of the Brazos, in eastern Texas, it had to be repealed because no individual could cultivate or make beneficial use of 4470 acres of agricultural land. 


\section{IRRIGATION INSTITUTIONS}

Land laws to succeed must be in accord with climatic requirements. A sealskin coat is an excellent garment in Greenland, but a useless one in Cuba. The Homestead Law served a beneficent purpose throughout large sections of the republic ; but it is not adapted to the settlement of a region where practically nothing can be grown except by artificial application of water. This fact has been learned at last through many years of hardship and disappointment, at the cost of many millions of dollars.

The Preëmption Law, passed in I84I, provided for acquirement of 160 acres of land from the public domain, by settlement and payment of $\$ 1.25$ per acre. The Homestead Law of 1862 provided for the acquirement of a like area by settlement alone, cultivation not being required. To the Preemption and Homestead laws there was added in I 873 the Timber Culture Act. This gave I60 acres to any one who would plant and cultivate trees on one-fourth of the area. The purpose of this law was good; but since trees will not grow on the arid plains of the West without irrigation, and there were easier ways of acquiring irrigated land than through this act, comparatively few filings were ever carried out in good faith. Out of nearly 250,000 entries less than 60,000 were proved upon, and but few of these complied with the spirit of the law where they fulfilled its letter.

In 1877 Congress passed what is known as the Desert Land Act, which gave 640 acres to any one 


\section{LAND LAWS OF THE ARID REGION}

who would irrigate it and pay to the government $\$ 1.25$ per acre. Residence on the desert lands was not required. Under these successive acts the area which an individual could acquire grew, as shown below, from I60 acres to I I 20.

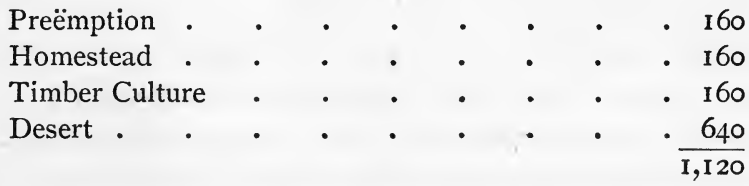

Eleven hundred and twenty acres is more land than any individual of moderate means can successfully cultivate. Especially is this true in the arid region. Whoever has the means to build the ditches and prepare this much land for cultivation does not need a present of land from the government. Even where these laws were honestly observed, the generosity exhibited was an economic mistake. The land which one individual could acquire should have been kept at a lower limit, in order that the public domain might serve the needs of a larger' number of people. Giving so large an area to a single individual encouraged speculation in land and the transfer of the more valuable portion of many irrigable valleys to men who acquired them, not to use but to sell. The inroads made on the public domain caused the country to become alarmed. In I 890 Congress began to restrict the amount of land which one individual could acquire. Filings under the Desert Act were reduced to 320 acres, and 


\section{IRRIGATION INSTITUTIONS}

both the Preëmption and Timber Culture acts were repealed.

In order to understand what is involved in the reclamation of the arid region, one must be informed of the intimate relation which exists between irrigation and the practical operation of the public land laws. It needs no argument to prove that good laws will promote development, and unwise ones retard it, but it has not been understood that from the beginning of Western settlement, the laws in force have been a potent factor in causing the financial failure of canals built to reclaim public land, and have thwarted instead of aided the efforts of the actual settler. In "The Conquest of the Arid Region" William E. Smythe characterizes these laws as "a system which cheats settlers, hampers enterprise, destroys investments, and lays broad and deep the foundation of economic wrong in the arid region." These evils are not due to a deliberate purpose, but to the inability of legislators to understand conditions they have never seen. The nation has suffered because Congress, in dealing with this question, has been adjusting things at long range.

The first step in the change from sage-brush deserts to fields of grain is the construction of the ditch or canal. Settlement before water for irrigation has been provided causes needless hardship. There is encountered at the outset a difference between agriculture by irrigation and agriculture by rainfall, which is radical in its 


\section{LAND LAWS OF THE ARID REGION}

nature. We have been accustomed to regard agriculture as a non-capitalized industry, and much loose talk has been indulged in about farmers creating homes in the arid West by their unaided efforts as they formerly did on the prairies of Illinois and Iowa. Those who attempt this find scenery and mountain air a poor support while building flumes and digging ditches.

This misconception of the preliminary outlay required has caused much serious hardship to individuals, and has stood in the way of enacting proper laws. Every one recognizes the need of capital and organization in the building of railways. There is no one who does not appreciate the necessity for money in starting a factory, and who would not recognize the absurdity of a hodcarrier trying, without aid, to erect a six-story block; yet many insist that the equally costly and more difficult construction which must precede the watering of arid lands, can be carried to completion by home-seekers, without either money, organization, or technical acquaintance with the problems to be solved.

To reclaim these lands there must be some security for the money expended. There must be settlers to use the ditches and till the soil if this money is to be repaid, and there must be such measure of State or national supervision as will protect investments in canals from confiscation and prevent canal companies from oppressing their patrons. 


\section{IRRIGATION INSTITUTIONS}

When the building of canals to water public lands began, investors in these properties believed they were masters of the situation. Experience often proved them to be its victims. The building of a canal changed the potential value of the land it covered from grazing to farming land, and often increased its selling price tenfold. These irrigable areas were the field for the land-grabber. A canal survey was a signal for a rush to the land office. While the land laws were doubtless intended to benefit actual settlers, speculators have often been able to forestall them. The opportunity to file on land under a ditch is usually gone before the actual settler knows of it. Men who are not farmers, and who have no intention of becoming such, fasten themselves, by speculative land filings, as parasites on ditch enterprises, or levy toll on the actual irrigator when he arrives.

When the Bear River Canal was begun in Utah, the land it was to water was an unoccupied sagebrush desert. Before its survey was completed, and in less than thirty days after it was begun, every acre of land had been filed upon. Three years later not one acre in fifty was being irrigated by the original entry men. Before the survey of the canal of the Wyoming Development Company was completed, six sections of the best land below it had been filed on by speculators. To protect itself, the company had to organize a syndicate to file on the land under the Desert Act. 


\section{LAND LAWS OF THE ARID REGION}

An empty canal is like a piece of idle machinery; it constantly diminishes in value. The winds fill it with dust, the sun shrinks its flumes, the storms wash its banks, so that dry weather and wet weather alike work its destruction. To the expense of keeping it in order is added the interest on its cost. Nothing can be more exasperating than the plight of the owners of a canal where the lands have been filed on by speculators instead of cultivators. Their property is a white elephant. The land-grabbers, are, however, serene. They are not required to cultivate their homesteads; only nominal residence for fourteen months is exacted, and until a patent is received there are no taxes. They can wait. The canal owner cannot, and many landowners sell out for high prices. The use of the Homestead Law in this way has wrecked many a meritorious irrigation project.

The Desert Land Law had no feature to warrant its original enactment, or to recommend its continued existence. Six hundred and forty acres of irrigable land was more than was needed for the support of any settler, and more than a settler of limited means could improve or cultivate. Irrigated land in Southern California is worth $\$ \mathrm{I}, 000$ an acre. To give away 640 acres of such land to a single individual was not generosity; it was a profligate surrender of a great public resource.

Under this law many thousand acres of land, which could have been reclaimed by actual settlers, have passed into the hands of non-resident 
owners, and are now held as speculative properties. The law has done nothing to promote the construction of large works, or to promote important investments therein, because it does not conform to physical facts. There is no reason for its existence in its present form, and it should be repealed. If there was an independent water-supply for each 320 acres, or if every man's canal could begin and end on his own land, this law would be an admirable institution; but when canals, if built at all, must be built to water very much larger areas, the Desert Land Act is a failure, and in large enterprises, if at all, is its only field of usefulness.

We have thus far considered the operation of the public land laws in relation to the investment of capital in irrigation works. They should promote this, and in addition they should promote the welfare of the people who are to make homes on the lands irrigated. They cannot do this so long as they ignore water for irrigation. The history of all irrigated countries shows the necessity of uniting with the soil the right to the water which reclaims it. Under our land system the ownership of these joint agents of production is divorced at the outset. Title to the land comes from the United States. Title to water comes from each of the several States. No right to water goes with a land patent. Each arid State has different laws governing water rights, and in only two is there legislation which favors the attachment of these rights to the soil. 


\section{LAND LAWS OF THE ARID REGION}

In arid countries water rights are of more importance than land titles. Without water, the land has little value. Wherever water and land are owned apart from each other, there is a tendency to create monopolies in water, and to place the tiller of the soil at the mercy of the owner of the stream. The natural, if not inevitable, result of our land system is to create such separate ownership and such speculative abuses. No industrial problem of the West equals this in importance. The institutions now being created will, in time, affect a population greater than that of the entire nation. The customs, which are the outcome of primitive conditions, will harden into laws, and abuses will become vested rights. No adequate system of irrigation laws, or any enduring prosperity for the people who till the soil, can be built on separate ownership and divided control of land and water. The fundamental condition of success is that these two joint agents of production should be disposed of together, and that with every title to irrigable land should go an interest in the stream which gives it value.

\section{Influence of State Lands and Special Land Laws}

When investors began to understand the dangers growing out of speculative filing on public land they looked first for means of escaping its evils. In two States, Colorado and California, this was comparatively easy. In Colorado irrigation companies 
purchased the lands granted to the Union Pacific and Denver Pacific railways. They were not then dependent on revenue from public land, and were not injured through its control by speculative filings. Later on irrigation companies arranged with State authorities to select the land they were to water, and then purchased it or bargained for its disposal by the State to actual settlers only. In California large tracts of irrigable land were purchased directly from the United States before limitations were imposed on the acreage which could be bought. Spanish grants controlled immense areas, so that irrigation has been confined almost wholly to private lands.

The State lands of North and South Dakota, Montana, Wyoming, Idaho, and Washington cannot be used to promote irrigation because the acts ceding them to those States require that they must be sold for $\$$ IO an acre, which is a prohibitive price.

In I 894 Congress passed what is popularly known as the Carey Act, which gives to each arid State the right to select $1,000,000$ acres of land and control its irrigation and settlement. Seven States accepted this trust. The laws of five of these States require actual settlement and cultivation of the land; limit filings to 160 acres; attach the water right to the land, and provide for the ultimate ownership by the irrigators of the ditches on which they depend. Wyoming was the first State to accept the grant, and has done the most under 


\section{LAND LAWS OF THE ARID REGION}

its provisions. The second and third largest canals in the State were built under this act. Three large projects have been begun under this act in Idaho. In Wyoming and Idaho land is sold for fifty cents an acre. Terms under which ditches are built and sold to settlers are fixed by a contract between the canal owners and the State, after investigation by the State engineer to determine whether the project is feasible, and whether there is water enough to irrigate the land.

Under this act, there can be no speculative filing on land or building of ditches for which there is no water. Rights to the use of water are acquired by neither canal builder nor landowner, but are attached to the land reclaimed and are inseparable therefrom. Irrigators own both the canal and the land, however, and know before entering upon the ownership what they are to pay for both, and that there will be an ample supply of water. The superiority of this law to any other arid land statute is unquestioned. It regulates both settlement and reclamation. It tends to secure the building of better works through State supervision, and insures their sale to settlers on reasonable terms. It protects canal companies against controversies with farmers, because the State fixes the selling price of the property. It protects the public against speculative ownership of either land or water. There is no profit in owning land not cultivated, since the cost of operating 
the canal is assessed on the land it is built to water, whether or not it is farmed.

So far as the limitations of the law permitted, it has proven a success in operation. The objection to it lies in the delay and expense involved in segregating the tracts to be irrigated. Maps and plans have to be approved, first by the State and then by the Secretary of the Interior. There is in this procedure an almost endless round of red tape, involving delays and expenses, which restricts the usefulness of the act to large projects.

There was an objection to the original act in the limitation of its operation to ten years. It takes ten years to settle the land under a large canal, and men have been afraid to engage in extensive projects, for fear the operation of the law would not be extended. The act of March 3, I90I, gives the Secretary of the Interior authority to extend the time for reclamation of lands not to exceed five years, making the whole time from the selection under the Carey Law not to exceed fifteen years.

Another objection to the law is that it is unfair to the several States. It requires them to assume the responsibility and expense in disposing of the land, to run all risks of financial loss in the building of canals, and to be at all times subject to the scrutiny of the Interior Department, yet in the final outcome, if there is any profit in the enterprise, it must be paid into the national treasury.

These criticisms have thus far been theoretical 


\section{LAND LAWS OF THE ARID REGION}

only, because there has been the most pleasant relation and cordial coöperation between the State and national authorities. Another unwise feature of the law is the prohibition against community fencing. This compels each individual settler under the ditch to fence his own land. If all the lands could be fenced in one tract, it would be a measure of economy at a time when every outlay bears most heavily on settlers. It must be kept in mind, however, that this law, even if modified as suggested, would still be inadequate legislation. No arid land law can be regarded as satisfactory or complete which does not provide for the construction of canals under public supervision and in accordance with some comprehensive plan, or which does not deal with the grazing lands in such a way as to provide for their union with the irrigable lands.

\section{The Grazing Lands}

The greatest product of Western America is grass. Although its growth is stunted, it is exceedingly nutritious and the dry air and absence of dews and rains, which cause it to cure naturally on its stem, make it possible for cattle, sheep, and horses to live on it in winter as well as in summer. When this discovery was made, the Great American Desert ceased to exist, and what is known as the range industry was born. From the Gulf to Canada, and from western Kansas and 


\section{IRRIGATION INSTITUTIONS}

Nebraska to the Sierras, the cattle round-up and the mess wagon followed close on the disappearing Indian and buffalo.

There was no law by which men could legally secure control of the land they occupied. All the land laws dealt with farming land. There was no provision for leasing or selling the grazing land in tracts large enough to be of any service. Hence the range stockmen simply took possession of the country. Each man chose a location which suited him, fixed in a rough way the boundaries of his domain, and helped to create a public sentiment which made it unpleasant, if not dangerous, for a later comer to attempt to share with him the territory he had so marked out. In this way, range rights came to have all the force of law, and the men who first occupied the country came to believe that they had a vested right to control it forever, and looked on every newcomer as an impudent intruder interfering with their moral, if not their legal, rights.

The control which men exercised over ranges was one of sentiment, however. The law made it illegal to fence. The absence of fences made it possible for live stock to wander long distances. The herds on contiguous ranges mingled together and made it necessary to establish ownership by methods not required elsewhere. The absence of permanent control and the inability to fence made of the whole country an open common and gave to the business a migratory character. Cattle 
trails extended for a thousand miles from the breeding grounds in the Southwest to the feeding grounds in the North. As one of the early stockmen, now President of the United States, expressed it, it was a region in which one could ride for days without meeting a man or seeing a house. Nevertheless, the entire country was parcelled out, and the boundaries of each man's territory fairly well understood.

The business of marketing cattle and of branding the increase ceased to be an individual matter. Associations were formed which divided States into round-up districts and placed the recording of brands, the branding of calves, and the shipment of grown animals under a sort of semi-public supervision. The State live stock associations had agents in all of the great shipping centres, who examined the brands of every animal shipped out of their States for sale, collected the money for strays and remitted it to the rightful owner. These associations also determined the time when the wandering herds on the plains were to be rounded up in the spring.

One of the evils of the range live stock industry has been the conflicts between the owners of cattle and the owners of sheep. Cattle do best when turned loose to wander at will on the range. Sheep, on the other hand, can be gathered together in large bands and their movements directed by a shepherd or herder; hence they are under better control than cattle. In addition, sheep eat 


\section{IRRIGATION INSTITUTIONS}

off the grass more closely than cattle, and the odor they leave on the grass and around drinking places is distasteful to cattle. Wherever there is a contest over the use of a particular district, the sheepman wins. As a rule the growing of sheep is attended with less risk and with greater profit than the growing of cattle, if the area grazed over and the injury done to the native grasses are disregarded.

On account of these facts the range sheep business has largely displaced the range cattle business in Utah, Idaho, Wyoming, Montana, and New Mexico. When the contest first began, the sentiment in favor of enforcing range rights was much stronger than at present, and sheepmen hesitated about encroaching on cattlemen's territory. When they did, the man who first reached his revolver usually remained. Although in theory the public lands were free to all alike, in practice men marked out dead lines, the crossing of which by an outsider too often meant a resort to firearms. The writer once travelled on a stage-coach which carried thirty-five Winchester rifles which were being rushed into action in one of these contests.

When the irrigator appeared, he did not find an unoccupied country. He had the unwelcome rôle of helping to crowd out his predecessor, the range stock owner. It is an unfortunate fact that there is an inevitable conflict between the migratory range industries and the increase in population which goes with the cultivation of the irrigable 


\section{LAND LAWS OF THE ARID REGION}

lands. As one has stated it, the natural tendency of the range industry is to create a country which requires trains to carry out the live stock, but whose people can travel on the cow-catcher of the locomotive. Irrigation tends to reverse this process, and the two cannot harmoniously develop together.

The absence of administration or control over the public grazing land brought irrigators and range stockmen into direct conflict. The coming of the settler worked inevitable hardship to the latter. He closed up the water fronts, built fences which were a menace to range herds in winter storms, and against which hundreds of cattle drifted and died. He not only absorbed the most valuable land by his filings, but turned his own herd or flock loose on the open range to share in its use with the original occupant. These injuries were aggravated in the mind of range stockmen by their belief that they had a vested right in the country. A homesteader, who had fenced his quarter-section, found the fence cut to pieces. To his remonstrance he received a reply that the man who admitted the deed had followed the Indian into that country, and that he intended to use the land as long as he should run cattle on the range.

The Nesters' war in Texas was a conflict between settlers and range stockmen, and there are few localities where friction has been entirely absent. In addition to the inevitable injuries, range stockmen have had to suffer from serious and unwar- 
ranted abuses. Many cowboys left their original occupation to become poor farmers in order to insure access to a stream and to make use of the support of real farmers in a war in which they proceeded to engage against their former employers. Farming was a pretence; their real occupation was stealing or "rustling" from range stockmen. In many sections this thievery became so bold as to practically defy law and order. The "rustlers" justified stealing from the range stockmen on the ground that they were only sharing in the privilege of free grazing of which the big stockmen had before had a monopoly, and they found protection in the bitterness felt by the honest farmer. The "rustler" fanned the hostility of the irrigator and the owner of range herds, and was for years a prolific source of misunderstanding and loss to both interests. The range stockmen too often retaliated on the irrigator for the injury which his coming had brought by driving the farmer's milk cows, his work horses, and small bunch of cattle or sheep away from the home range. In some instances this worked no more serious damage than a loss of time hunting for them, but where the irrigator combined farming with stock raising, such hostility was disastrous.

Thereare many sections of the West where control of the range is the most vital problem which confronts the settlers, and it is the one which they first endeavor to solve. Sometimes they succeed, sometimes there is continuous friction and controversy, 
and, in recent years, the conflicts thus provoked have been serious, and their ultimate consequences often disastrous. Thousands of sheep closely herded together not only eat off all of the vegetation, but their feet trample the loose soil, expose the roots of the grass to the burning heat of the sun, and the result is that the growth of grass is permanently impaired. A repetition of this for two or three seasons often results in its complete destruction. In the place of grass there appear weeds and cactus, and one-half the value of the irrigated farm has been destroyed. Irrigated ranches along some streams have been abandoned because farming could not be carried on at a profit without combining it with the use of the range, and this could not be done because the grass has been destroyed.

In one way and another there has been great waste and loss in attempts to evade the administration of the laws which govern the public lands. A final settlement of this question has been rendered difficult by the opposition of every one who is still able to use the public land without paying for it, toward any legislation which will require him to make such payment. Although all those who have leased lands have learned that the security it gives is worth far more than the cost of rentals, the fact remains that all those who now have free use object to any sort of laws which will compel them to either rent or buy. Instead of a willingness to pay for what they use, they have 


\section{IRRIGATION INSTITUTIONS}

endeavored to secure, indirectly, a continuation of the free use of the public lands by many ingenious makeshifts of State legislation. Nevada has passed a law which imposes a prohibitive tax on flocks pastured on the open range when owned by others than freeholders in the State. Idaho has a similar law. Other States have passed quarantine laws, the sole purpose of which was to prevent flocks of sheep being driven across their borders from other States. Bills to prohibit the grazing of range flocks within three miles of a settler's fences have been introduced in more than one State legislature. Many settlers, who would gladly lease, fear that if a leasing law is put in force, it will be so perverted that all the land bordering their ranches will be absorbed by the owners of large flocks and herds, and that the evils they now suffer will only be aggravated.

The attitude of the range stockman has been largely determined by his ingrained feeling that he is entitled to the free use of this country, and that anything which compels him to pay for its use is an interference with his vested rights. In his efforts to maintain this privilege, he has not always been scrupulous as to methods. Press bureaus have been maintained for the purpose of denouncing every advocate of leasing and misrepresenting the reasons therefor.

Competition has, however, every year become more severe, and this has forced men to violate the law and to commit acts which they heartily 


\section{LAND LAWS OF THE ARID REGION}

disliked. Millions of acres of land have been illegally fenced. This has been winked at because the necessity for it has been realized. Men have paid extravagantly high prices for land scrip to file on the lands bordering streams and water holes in order to control the water-supply. Only those who have lived in the range country and have seen the long stretches of ashy, dusty plains, over which the air waves and trembles with heat under a sun which scorches the skin and dazzles the eyes, can understand the meaning of water. Whoever controls it controls the grazing country, because stock need water as well as grass.

The chief agencies for securing title to land along water fronts have been the Desert and Homestead land laws. The Desert Act does not require residence; the party filing might live in New York, Boston, or Chicago. Six hundred and forty acres of land stretched along a stream in forty-acre tracts would control four miles of water front. At the time when this law was most used, men found little difficulty in complying with the regulations governing proof. In the ten years from 1876 to 1886 millions of dollars were spent in building ditches to acquire title to the lands under this act.

The collapse came in the winter of 1886 , which is historic for the disasters wrought in the range cattle business. A dry summer was followed by a bitter winter. Overstocking of ranges had destroyed the grass, and sheep and cattle perished, 


\section{IRRIGATION INSTITUTIONS}

by hundreds of thousands, from cold and starvation. The blow fell with crushing weight. Fortunes which had been made almost in a day were as quickly lost. The banks of many western cities closed their doors. Colonies of university graduates and members of wealthy families from eastern cities and from Europe, attracted by the novelty and charm of Western life, melted away. The former kings of the range had to retire, and the foundation industry of nearly one-fourth of the United States underwent a reorganization. As a part of this reorganization, ditch building ceased to be a pretext for land-grabbing, and the growth of actual irrigation became legitimate and honest. Stockmen began to use ditches already built to irrigate fields for winter feed, and cultivators of the soil found a hearty welcome and larger opportunities than before.

In recent years the high price of live stock has again intensified the competition over the open range. Men who need to control the land they pasture are unable to either buy or lease it directly. Evading the law is expensive but not impossible. Recently soldiers' widows have been gathered together in the East and shipped in car-load lots to Western land offices to make homestead filings for stockmen. Seventy-two such filings were made in one day at Valentine, Nebraska, and thirty at Alliance, Nebraska. The law most used is the Homestead Act. Any one on whom the sanctity of an oath rests lightly can materially increase 


\section{LAND LAWS OF THE ARID REGION}

his bank account by using his homestead rights for some range stockman. School-teachers, sheep herders, cowboys, workmen on railways, men in all walks of life, have permitted their names to be utilized for this purpose. The method is simple and easy. It involves the building of a claim cabin, the sleeping on the claim two or three nights during a period of fourteen months, and the commutation of the remainder of the residence period by the payment of $\$ 1.25$ per acre. The perjury incidentally involved in this does not count. It is too common to be noticed.

The rapidity with which the land along streams is passing into comparatively few hands under the operation of this act is astounding. The report of the commissioner of the land office for I90 I shows that the total homestead entries of all classes aggregated I I I,390 and embraced I 5,455,057 acres. This is 9488 more homestead entries than were made in any previous year since the passage of the Homestead Act nearly forty years ago. It is nearly one-fourth as many final entries as were made in the entire nineteen years following the passage of the act.

This activity does not indicate the use but the abuse of the Homestead Law. The lands are not taken up to create homes, but to control the public range. The areas which are being absorbed lie along the streams. They are the best of the remaining public lands. The rapidity with which they are passing from public into private control is 


\section{IRRIGATION INSTITUTIONS}

lessening the opportunities for stockmen and irrigators, is placing an obstacle in the way of public irrigation, and is creating monopolies of the grazing land which should be prevented.

The administration of the grazing lands has been long delayed, but the march of settlement will sooner or later force Congress to take action. If the value of the grazing lands is to be preserved, there must be some sort of administration which will put an end to the destructive overstocking and make it to the interest of individuals to protect and improve the areas they use. Whatever shape legislation takes, it should provide for the union of the irrigable and grazing lands. The irrigated homestead should be reduced in size in order to provide homes for the largest number of people, but its reduction should be offset by giving to the settler the right to lease a larger, but limited, area of grazing land. The chief industry in much of the West will always be the growing of live stock. Uniting the irrigable and grazing lands will divide the latter into a multitude of small holdings, increase the number of people benefited, and make the growing of live stock attractive to many who are now repelled by the risks and controversies of the open range. It will encourage the introduction of improved breeds of live stock, which cannot now be placed on the open range because of lack of protection. Stock will be better fed and better cared for in winter. A humane industry will replace the gamble with death by cold 


\section{LAND LAWS OF THE ARID REGION}

and starvation which has long been a reproach to stock growing in many parts of the West. It will enlist self-interest in improving the native grasses where every influence now tends toward their destruction.

The grazing lands should be leased, not sold, because the limit of irrigation has not been fixed; nor are the possibilities of these lands sufficiently known for the limits of the homestead to be marked out. Care should be taken that these leases do not interfere with actual settlement. This can be done by having the lands classified by the general government, and the grazing and irrigable areas segregated, or by having every lease subject to entry by the actual cultivators under the Homestead Law. The increase of leasing would bring about more settled conditions, and give to the irrigator a secure tenure in the use of the lands he needs. It can also be made a most effective instrument in promoting the construction of irrigation works. If it is adopted, it will inevitably result in returning to the government a large sum of money. At a rent of one cent an acre, the annual income will be several millions of dollars. The experience of the arid States in leasing the lands donated to them at the time of their admission affords ample proof of this. Colorado leases over 3,500,000 acres at an average rental of eight cents an acre. Montana leases nearly $\mathrm{I}, 000,000$ acres of State lands at a rental of over eleven cents an acre. Wyoming leases nearly 2,000,000 


\section{IRRIGATION INSTITUTIONS}

acres at an average of over four cents an acre. The rentals in Utah average nearly six cents an acre. The Union and Northern Pacific railways lease nearly 2,000,000 acres at rentals varying from one to seven cents an acre.

The leasing bill introduced in the fifty-seventh Congress by Hon. J. F. Lacey, the chairman of the committee on public lands, ${ }^{1}$ embodies all the essential features of a successful leasing law. It is believed that the majority of irrigators would favor legislation of this character. Their opposition is due to a fear that the grazing lands would be absorbed in large leases. The bill referred to would prevent this.

1 H. R. No. 14,108, 57th Congress, First Session. 


\section{CHAPTER III \\ The Beginnings of Irrigation}

\section{History}

IRRIGATION on the American continent is older than historical records. In various parts of the Southwest, notably in the Salt River Valley of Arizona, in northern New Mexico, and in southwestern Colorado, are well-defined remains of irrigation works which have outlived by many centuries the civilization to which they belonged. Even modern irrigation is comparatively old. It began seventy years before the English colony landed at Jamestown, when Spanish missionaries gained an enduring foothold in the valley of the Rio Grande. They built churches which still stand and planted gardens which still flourish; but, in watering these gardens, they taught nothing new to the native inhabitants. The Spanish explorers, who rode up the valley of this river in the first half of the sixteenth century, found Pueblo Indians irrigating the thirsty soil as their forefathers had done for centuries before them, and as their descendants are still doing.

When, in this valley and along tributary streams, and in other places in the desert wastes of the Southwest, Spanish settlements sprang up, they 
maintained themselves by means of these lifegiving waters. The ditches of Las Cruces, New Mexico, have an unbroken record of three hundred years of service, the history of which is written in the banks of the canals by the sediment with which the water of the Rio Grande is laden. Year after year this has been deposited on the sides and bottoms of these ditches, until from being channels cut out below the surface, they are raised two or three feet above. It is here that one can yet find agriculture almost as primitive as that of the days of Pharaoh, where grain is reaped with the sickle and thrashed by the trampling of goats.

For the beginnings of Anglo-Saxon irrigation in this country, we must go to the Salt Lake Valley of Utah, where, in July, I847, the Mormon pioneers first turned the clear waters of City Creek upon the sun-baked and alkaline soil.

Utah is interesting not only because it is the cradle of our modern irrigation industry, but even more so as showing how important are organization and public control in the diversion and use of rivers. Throughout their pioneer period the settlers of Utah were under the direction of exceptionally able and resourceful leaders, who were aided by the fact that their followers were knit together by a dominating religious impulse. These leaders had the wisdom to adapt their methods of settlement and shape their institutions so as to conform to the peculiar conditions by which they were surrounded. (They found that irrigation was necessary 


\section{THE BEGINNINGS OF IRRIGATION}

to existence in the home they had chosen, and that the irrigating canal must therefore be the basis of their industrial organization.

That the great material results which quickly followed their settlement could have been realized without the cohesion which came from an association dominated by religious discipline and controlled by the superior intelligence of the head of the Mormon church, is doubtful ; but that this success was aided by the fact that they brought with them institutions suited to their environment is beyond dispute. Cooperation had been a dominant principle of their organization in Illinois and Missouri, but it took on new power when they migrated to a land without capital, where it was beyond the power of the individual to turn the mountain torrent from its course and spread it upon his lands. (Only the labor of many individuals, working under organization and discipline, could build the necessary canals or distribute the waters carried in them.) A small farm unit was chosen, not because men were less greedy for land than in all other new countries, but because it was quickly seen that the extent of the water-supply was the measure of production. Diversified farming, which is one of the leading causes of the remarkably even prosperity of Mormon agriculture, was resorted to because the territory being settled was so far removed from other settlements as to make it absolutely necessary that it be self-sustaining. The small farm unit made near neighbors, and this advantage was still more 
enhanced by assembling the farmers' homes in convenient village centres.

The discovery of gold in California created the Overland Trail, which wound its tortuous course across the hitherto trackless wastes of the arid domain. Its stations were usually along the banks of streams. In the neighborhood of these stations settlers established themselves, and by means of simple furrows turned water upon the bottom land. Outside of Utah this was the extent of irrigation throughout the vast region from the Missouri River to the Sierras before the founding of the Union Colony at Greeley, Colorado, - the second historic step in establishing Anglo-Saxon irrigation in this country, - a step which furnishes a different standpoint for study from that of the Mormon settlement in Salt Lake Valley.

As Utah is the result of a religious emigration, so Greeley is the creation of the New England town meeting transplanted to the far West. Its founding marked the beginning of a new and different industrial development in Colorado. Before the colony became noted, the wealth of the mines or the migratory and adventurous life of the range live-stock men had been the chief magnets in attracting settlement. Greeley represented an effort of home-making people to enjoy both landed independence and social and intellectual privileges equal to those of the towns and cities they had left. Among its first buildings was Colony Hall, and among its first organizations the Lyceum, in 
which all the affairs of the community were debated with a fervor and fearlessness quite worthy of Horace Greeley's following.

The best methods, both of irrigation and cultivation, were sought out through numberless experiments, until Greeley and its potatoes grew famous together. The homes and civic institutions of the colony became the pride of the State, and the hardwon success of the community inspired numerous similar undertakings and furnished an impulse which resulted in the reclamation and settlement of northern Colorado. Boulder, Longmont, Loveland, and Fort Collins were the outgrowth of this success, and each adopted many of the ideas and tendencies of the parent colony.

Twenty years subsequently to the beginning in Utah, and contemporaneously with the settlement of Colorado, similar influences began to make themselves felt in California, especially in its southern part. Colonies at Anaheim and Riverside were coöperative in their inception, and have since remained such, and their example has been a potent factor for good; but it was not powerful enough to control the spirit of speculation which has pervaded the industrial life of California and which fastened itself on irrigation as it had done on mining. Irrigation soon became corporate and speculative. The watering of stocks and bonds shared profits - or loss! - with the watering of land in too many of the early enterprises.

In Wyoming, Montana, Idaho, and Nevada, 
grazing lands, rather than irrigable lands, have been the leading factor in local development. The need of a winter feed supply for range live stock has led to the construction of ditches remote from local markets, and has limited irrigated agriculture over large areas to the production of forage crops. And because of this all statistics of the value of irrigated lands and water rights in these States are misleading as an index of their future possibilities. This does not mean that land and water will ever be as valuable here as in some sections of California, Arizona, and New Mexico; but with increased railway facilities, and changes in agricultural methods, there will be more economical and skilful use of water. In these States, more than in any others, lie the possibilities of the future, because here rise the great rivers of the arid region, the Snake, the Missouri, and the Colorado, which, with their tributaries, control the industrial future of a region larger than most European countries.

With this outline of the growth of western irrigation, let us next consider what has been accomplished.

We are met at the outset by an entire absence of definite information. We do not know how many irrigation works have been built. In many States no provision is made for their record. In only two States is the record even approximately accurate or complete. There may be 75,000 ditches, 


\section{THE BEGINNINGS OF IRRIGATION}

or there may be fewer or more; but either as to their number or the acreage reclaimed, we are limited to estimates.

It is exceedingly difficult to determine the cost of ditches and canals. Some companies hesitate to disclose the cost of their works; some decline to do so, and others do not know. The numerous items of expense involved in the construction and operation of a large irrigating canal during the first ten years of its life cannot always be classified. These works are not built with the same preliminary care and expense as the irrigating canals of Europe. There is usually a rush to get water on a portion of the land to be irrigated. It is not necessary that the ditch should be completed to its utmost capacity. Top planks may be left off flumes; waste ways may be left for construction in future years; headgates may be of temporary construction, to be made permanent later. Often construction expense runs into operating expense, until it is hard to separate the two items.

This, however, is known: That the highestpriced and most productive farm lands on this continent are in this arid region; that the largest yield of nearly every staple crop has been obtained by the aid of irrigation; that not only has the growth of agriculture furnished a market for the factories of the East, and supported the railroads which unite the two extremes of the country, but it is the chief resource of many arid States. Colorado leads the Union in her output of precious metals, but the 
product of her farms equals in value that of her mines. In California many of the cities are as truly the products of irrigation as the orchards which surround them. This can be said of Los Angeles, Riverside, Redlands, Pasadena, and Fresno. The beginnings of Utah were wholly agricultural, and without the irrigated farms the cities of that interior commonwealth would as yet be only dreams. In less striking degree the same condition prevails in Idaho, Wyoming, Montana, Nevada, New Mexico, and Arizona.

\section{Methods}

The first irrigation works in the West were of the most primitive character. A simple furrow turned part of a creek or river upon the low-lying bottom-land adjacent. In few cases did the earlier ditch builders have to make a cut of more than five feet in order to place the bottom of their ditch level with the bottom of the stream. For five hundred miles along the eastern base of the Rockies the plain which borders it slopes away from it with a fall varying from ten to one hundred feet to the mile. The mountain torrents, as they leave their canyon walls, have an equally rapid fall. Ditches with a fall of three feet to the mile could soon reach the surface of the land to be irrigated. There was seldom need of building dams, usually a temporary structure made of bags of sand or a combination of stones and brush, requiring only a 


\section{THE BEGINNINGS OF IRRIGATION}

few hours, or at most a few days to construct, would serve. Headgates were an exception rather than a rule. A few shovels of earth provided an embankment to keep out the water when not needed, and a few strokes of the same shovel opened a way for its passage when irrigation began. Engineering advice was seldom sought. No attention was paid to alignment. Ditches followed the contour of the surface, and some of them were so crooked as to be wasteful of both land and water. The needed slope was given to the ditch in some cases by beginning at the head and letting the water follow the excavation, in others by filling a pan with water and sighting across its opposite edges. By many ingenious home-made designs the individual irrigator, working alone, was able to water his garden or little farm. In time irrigators became very expert in determining where water would or would not run, and could locate their ditches or laterals with surprising success without the aid of any instruments whatever.

Returns from irrigation were large. Owners of gardens along the Overland Trail sold their cabbages for $\$$ I a head and their potatoes for 50 cents a pound. Flour sold in Alder Gulch, Montana, for $\$$ IOO per sack and in many mining camps hay brought $\$ 100$ a ton. With such returns following irrigation, ditches were built wherever men settled, in the vicinity of mining camps, around the stage stations of the Santa Fé and Overland trails, in the Mormon colonies of Utah, around transplanted 
New England at Greeley, Colorado, or on a sheep or cattle ranch in Montana.

In time larger and costlier ditches were undertaken in order to reach the broader and better lands away from the margins of streams. Irrigation grew as a tree grows, by putting out new branches in some cases and extending older ones in others. The later settlers would either seek out new locations or enlarge and extend the ditches already built. In this way a single furrow, built to irrigate ten acres, came in time to be a broad and deep canal watering thousands of acres. The Larimer and Weld Canal was built in I864 to water 800 acres. It was enlarged in the seventies to water 40,000 acres. While once a single owner controlled this ditch, it came in time to be a partnership affair in which several hundred farmers had an interest. In other cases, men would at the outset associate themselves together to build waterways too. expensive and costly for one individual to control. It was soon apparent that overcoming physical obstacles is only one of the problems of irrigation. The needed training in coöperation and association was conspicuously lacking in the early irrigators. They not only did not know how to work harmoniously together, but they had inherited prejudices against submitting to the restraint and control needed to make associated effort a success. Many partnership ditches were begun without any written agreement or welldefined understanding as to what was to be each 
man's share in the project when completed, how much work he was to do, or how much water each was to receive.

The first districts irrigated were oases in the desert, separated from each other by wide areas inhabited chiefly by the coyote and Indian. Ditch builders along the Poudre River in Colorado knew nothing of what irrigators were doing in Utah, while those of Utah were equally ignorant of what was being done in California. There were no laws to control the organization or management of coöperative ditch companies, no means by which the people who entered into them could secure control of the land that was to be watered outside of what they filed on, and in the absence of any able outside direction such as was had in Utah the controversies which arose took many forms. Enthusiasm or the press of need would suffice to build partnership ditches, but friction would disrupt their subsequent operation. Human selfishness would then assert itself. The man whose land was near the head of the ditch did not need to keep it in repair; so long as water for all others had to run past his lateral, the people below him would have to attend to this or do without. The irrigator having this fortunate location showed equal ingenuity in manipulating his headgate so as to take more than his share of the water, while the unfortunate irrigator at the lower end of the ditch found himself doing more work and getting less for it than the other members of 
the partnership. Until farmers learned that they must place the control of their ditch in the hands of one individual, there was either murder or suicide in the heart of every member of the partnership.

The experience of the Greeley Colony illustrated the difficulties which beset coöperative ditch enterprises, and explains why corporate works came as a natural and inevitable evolution in our irrigation development. The founders of the colony were men of national reputation, its rank and file were above the average in intelligence, and they emigrated to a new country to secure better social conditions rather than financial gain. Many came from the farms of New England and the Northwest, and consequently knew how to work and how to economize. The possession of a certain amount of money was one of the conditions of membership in the colony, thus insuring from the outset at least a portion of the funds that would be necessary in actual settlement. One of the most favored spots in the West was chosen for the enterprise. The soil was fertile and the water-supply ample for the needs of agriculture. The canal had no serious engineering difficulties, and the crops which the colonist grew were those they had previously grown in the East. Nevertheless, the ditches nearly wrecked the colony.

In the first place, no one knew how much water was needed to irrigate an acre of land, nor the number or size of the ditches necessary to reclaim 


\section{THE BEGINNINGS OF IRRIGATION}

the area proposed to be settled. Four ditches were projected to irrigate about 120,000 acres. The estimated cost of these four ditches was $\$ 20,000$, and this amount was accordingly set aside for the purpose. But the first of these ditches cost $\$ 30,000$, and instead of watering 120,000 acres, it failed to water the 2000 acres planted the first year because it was too small. The colonists were in a quandary. The ditch had to be enlarged, yet the funds set aside for ditch building were exhausted. Having lost a year's time through the failure of the first crop, the farmers were in no mood to provide additional funds; and if the ditch project, which thus far had been looked after by those of the colony to be especially benefited, had not been aided by the central organization, it would have found an early and inglorious end. Some of the colony lands were sold and money finally raised from the farmers, so that two enlargements of the canal, one costing over $\$ 42,000$, were carried through. Later, additional funds were raised, and over \$I 2,000 was expended before the ditch was finished. Even then the ditch irrigated only about 32,000 acres, or about one-fourth the area included in the original estimate. The other three canals of the original scheme have since been built by other parties, at a total cost for the four of $\$ 400,000$, or twenty times the first estimate.

The difficulties that were experienced in holding together the farmers under the Greeley Canal 


\section{IRRIGATION INSTITUTIONS}

would have been fatal to a project of similar magnitude lacking the support of a central organization like the Union Colony. The reasons for this are not hard to find. There are abundant opportunities for mistakes in estimates of cost. These estimates are nearly always too low, and when much too low almost inevitably wreck an enterprise. Again, the hardships encountered during the first years of settlement and before water can be turned upon the land are more than most men will endure. Unless water can be supplied to grow a garden the second year after settlement begins, there is certain to be an exodus.

The great danger of partnership ditches is the failure to realize at the outset the need of adequate organization. There exists among farmers a prejudice against corporation methods, and in their efforts to avoid following them, disagreements arise usually over the distribution of water or the expense of management.

In the operation of corporation ditches an annual charge is levied for the water furnished, based either on the acreage irrigated or the volume of water to be delivered. From this the operating expenses are paid, and dividends declared upon the capital stock. This is also the plan pursued by the most successful partnership ditches, but with many no charge is made for water furnished. Instead, an assessment is levied upon the shares of stock each season to meet operating expenses, while the dividends are represented by the water 


\section{THE BEGINNINGS OF IRRIGATION}

furnished. It often happens, however, that stockholders either own no land or own land which is not being irrigated, and are called upon to pay assessments from which they derive no benefits. On the other hand, their assessments lessen the cost and increase the water-supply of the actual irrigators. This situation is not satisfactory to the holder of unused shares. His only source of relief is to rent his shares to some needy irrigator. Then the lack of a definite understanding over this matter often results in a lawsuit.

The irrigation works of Utah are usually referred to as being partnership ditches, built by the unaided efforts of the settlers who used them. This is hardly correct. Coöperation in Utah gained cohesive strength through the dominion of the Mormon church. Ditch builders did not have to rely on their own resources or depend upon their unaided wisdom or experience. The great scheme of public improvement which made Utah an important agricultural commonwealth was largely planned and carried out under the aid and direction of Brigham Young and the church of which he was the head. The projects of this great captain of industry had more the character of State improvements or of fully organized business corporations than of the crude coöperative enterprises undertaken by the unorganized ditch builders of other states. But even under the capable management and financial support of the church, coöperation of settlers was not equal to the task of building all 


\section{IRRIGATION INSTITUTIONS}

of the irrigation works of Utah. For forty years the table-land at the north end of Salt Lake Valley remained unoccupied, while the sons of pioneers sought homes in other states. The engineering skill, and the more than million dollars required to carry water along the three miles of precipitous sides of the Bear River Canyon, and build the long, high aqueducts to bridge the Malade River, were more than local effort could provide.

Ideal conditions exist where each irrigator owns a share in the canal, and each farm has a share in the stream, and some of the ditches built by the people and for the people have come near to realizing these conditions. This is true, in practice if not in law, of many of the partnership canals of California, Colorado, and Utah. Under the best of these systems, water is furnished at less cost, and there is more security and content in homes, than under any other system yet devised, but no plan, however perfect in theory, can succeed unless common sense is employed in its operation. When the owners of a ditch submit themselves to needed direction and control, when they adopt the methods which experience has shown necessary in the management of any large enterprise, their success has surpassed that of the corporate ditches; but farmers have too often refused to do this. Civilization has not yet reached the point where men, without preliminary training, can work harmoniously together, as is shown over and over again in other forms of coöperative enter- 
prise. That the arid region is destined to be one of the training schools in coöperation is fully believed, but the conditions were not ready for this at the outset, and in time there came the third step in irrigation development, which was the building of corporation canals.

The investment of corporate capital in canals to distribute and control water used in irrigation began in California, but spread rapidly throughout the West. For a quarter of a century it has been the leading factor in promoting agricultural growth of the western two-fifths of the United States. It has been the agency through which millions of dollars have been raised and expended, thousands of miles of canals constructed, and hundreds of thousands of acres of land reclaimed. It has been the chief agency in replacing temporary wooden structures by massive headworks of steel and masonry, and, by the employment of the best engineering talent and the introduction of better methods of construction, has promoted the economy and success with which water is now distributed and used.

The construction of irrigation works by corporate capital came as a natural if not inevitable result. There came a time in the districts first settled, when the opportunities to divert water cheaply had largely been utilized, and when the expenditure required was beyond the means of the individual or the coöperation of many individuals. The preliminary outlay was too great. In 


\section{IRRIGATION INSTITUTIONS}

Europe and Asia nearly all the large canals are owned and operated as state works. In some cases this is due to the financial unprofitableness of private works; in others to the fact that the state seemed the proper agency to make the large expenditure required and also the safest to exercise the power over the welfare of communities which the control of water gives. Large irrigation canals have been considered as being, in their nature, such public improvements as are works to supply water to cities and towns. Being for the service of the public, those in older European countries have largely passed under public ownership.

In this country corporations have, so far as construction is concerned, taken the place of governmental agencies in other lands. Practically all of the larger and costlier works built within the last two decades have been of this character. The High Line Canal, which waters the land surrounding Denver, Colorado, with its tunnel through the mountains and its aqueduct carried along the rocky cliffs below; the canal of the Wyoming Development Company, with its tunnel alone costing more than all the Union Colony canals of Greeley combined, as have its reservoirs for storing the entire year's discharge of Laramie River; the Sunnyside Canal of Washington, which when built traversed sixty miles of sage-brush solitude, - are illustrations in three States of the nature of corporate contributions to irrigation development. Even 
in Utah, coöperation was not sufficient to reclaim all of Salt Lake Valley.

Water-right complications came with the building of corporation canals. Previously to this, it had been the rule for those who built ditches to own the land they watered, and there was little practical difference as to whether the right to water went with the ditch or with the land, because the ownership of both was united in the same person. But when companies were organized to distribute water for others to use, there arose the question as to who was the owner of the right to the water diverted, - the company transporting the water or the farmer who applied it to the land. 


\section{CHAPTER IV}

\section{The Doctrine of Appropriation}

With the exception of Texas and the comparatively small areas included in Spanish and Mexican land grants, the arid West was a part of the public domain. The laws providing for the disposal of public land extended to this region, and as settlement proceeded, land offices for the convenience of settlers were established. The failure of these laws to meet the requirements of an arid region has been discussed in a preceding chapter. The same lack of knowledge which led to the extension to the arid region of land laws created for humid sections led to a far more important oversight: The streams which give value to the arid lands were left to be divided or fought over by settlers in whatever way they might choose.

The first generation of irrigators gave no thought at the outset to their right to use creeks or rivers. They found water running to waste and put it to use, just as they breathed the pure air or enjoyed the abundant sunshine. They saw no more need of making an official record of diverting a stream than of keeping a record of the elk and antelope they shot for food. The water of the streams and the wild animals of the plains were a part of the bounty of nature in a land of primitive conditions 


\section{THE DOCTRINE OF APPROPRIATION}

and of unused resources, and they shot the wild game for meat and used the streams to provide bread with equal disregard of the declining importance of the one or the growing importance of the other. It is not strange that they failed to foresee that irrigation was soon to be a leading industry of many States, and that the social and industrial institutions of millions of people were to be shaped by its requirements. Every step from the first furrow of the ditch to the last watering of the crop was an experiment in a new and untried field. The industry and its surroundings were strange. Nothing was known of the laws and customs of other irrigated lands, and the pioneer farmer of the arid West cared little for such knowledge. He was occupied with physical obstacles. So long as it required all his efforts to provide food and shelter for the present, he had little concern for the future. The conditions under which he labored were such as to cause even the most thoughtful to neglect the problems which development was creating. The early settlements were small and widely separated. There was an almost complete failure to understand the overshadowing importance of streams, or to realize that a climate so different from that of the East as to modify profoundly the structure of plants and the colors and habits of animals required a corresponding modification of laws and institutions to bring human settlement into harmony with its environments. 


\section{IRRIGATION INSTITUTIONS}

It is now realized that the federal government should have asserted the same ownership over the public water that it did over the public land, and disposed of both together. Rights to streams could then have been acquired by some orderly and systematic administrative procedure. The government could either have granted franchises to take water for a long term of years, as is done in Italy, or have granted perpetual licenses, as is done in Canada. Under either plan, titles to water would have come from the public, and their peaceable protection would have been assured. The failure of the Federal or State governments to assert public control over streams and dispose of them as a great public resource, left water to be dealt with as though it belonged to no one, and could be appropriated as men would a nugget of gold found on the mountain side.

In the absence of public control men took the water from streams and used it; that is, they "appropriated" it - using the word "appropriate" in its ordinary sense - to take for one's own use. When water laws were enacted, this practice was legalized and the basis of such laws became known as the doctrine of appropriation. This doctrine is opposed on the one hand to the common-law doctrine of riparian rights, under a strict interpretation of which water must not be taken from the streams unless it can be returned undiminished in volume, and on the other hand, to the limitation of all rights to use and to permanent public control under a sys- 


\section{THE DOCTRINE OF APPROPRIATION}

tem whereby all water is disposed of by license, which has been adopted in some European countries, the British colonies, and a few of the arid States.

Originally the doctrine was simply that any one needing water had the right to take it. The changed conditions in the West, the result of growth in population, and a consequent increased demand for water, have led to the many limitations and modifications which are discussed in the following pages. Volumes could be filled with the definitions of appropriations made in court decisions, but these decisions do not agree. What follows, therefore, must be understood as a general outline, which is subject to greater or less variation in different States and in different communities of the same State.

So long as streams carried a surplus, water was diverted and used without restraint and with lavish prodigality. Irrigators gave scant heed to their respective rights, because so long as each had all he needed, one right was as good as another. In time, however, conditions changed. Irrigated agriculture ceased to be an experiment and became an assured success. Streams which could be diverted at a small cost were sought out by ditch-builders, who found them in Colorado along the eastern base of the Rocky Mountains, and in Salt Lake Valley, Utah, along the western base of that range. The charm of the climate and the productiveness of the soil in California also drew 


\section{IRRIGATION INSTITUTIONS}

men to its valleys, and in these three favored States there were soon many streams where the needs of the crops were greater than the watersupply. Wherever this condition existed, contests arose. In each case the causes were much the same. Where a few users at first had the entire supply, scores, and even hundreds, of later comers came in time to compete for its control. With each recurring season of low water, the owners of ditches farthest down stream watched with anxious hearts the results of the labors of their neighbors above. Whether they saw it or not, they knew that farms were being watered from the supply on which they depended. As they saw the stream shrink in volume, and the torrent of the mountain canyon become a tiny thread in the sand of the plain, they realized that too great freedom in the use of water had its disadvantages. Whenever settlers on the lower part of the stream were robbed by irrigators above, they realized that far up in the mountains as much water ran as in former years, and that their fields were dry because of increasing, and often wasteful, use above them. The failure of their year's efforts was aggravated by contrast with the assured success of their neighbors who took the stream they needed. Men who had hitherto believed and proclaimed that water, like air, must be left free to all, learned what before they had failed to realize, - that to make this a working policy, water must be abundant enough to supply the needs of all. 


\section{THE DOCTRINE OF APPROPRIATION}

Justice seemed to demand that when there was not water enough for all, those who first used water from a stream should have the better right to continue that use, and the doctrine of priority was the result. This doctrine grew out of the belief of the first settlers that their claims were superior to those of later comers, and they insisted that the owner of the last ditch built should be the first to suffer when the stream failed to supply the needs of all. The first builders of ditches could not anticipate how many were to follow. Unless protected by some such principle, the greater their success, the sooner they would be injured by the attempts of others to benefit by their experience. The general principle that among appropriators the first in time is the first in right, is now a recognized rule in the water laws of the arid region.

As many ditches were built about the same time, it became necessary to prescribe rules for determining when the right should attach. If the right should date from the time of actual use of the water, a premium would be placed upon poor construction, and it might happen that during the construction of a large canal smaller canals or those more easily built might be begun and completed and appropriate all the water, leaving the large canal a total loss to its builders. To avoid this the doctrine of relation has been adopted; that is, the right does not date from the time the water is used but relates back to the time of the beginning of the work. To prevent an abuse, this doctrine has 


\section{IRRIGATION INSTITUTIONS}

been modified by the provision that the work of construction must be carried on with due diligence. Under the doctrine of relation, a water right is initiated when the work of construction begins, and dates from that time, but is not perfected until the water has been actually diverted and used. The question of what is due diligence is a question of fact to be determined in each particular case, and when such diligence is not used, the right dates from the time of use.

In some of the States a distinction is made between the different uses to which water may be applied. In Colorado, Idaho, Nebraska, and western Kansas appropriations of water for domestic purposes take precedence over appropriations for irrigation. In California, Montana, Nevada, New Mexico, Washington, Wyoming, Texas, North Dakota, and Oregon, no distinction is made between uses. In Utah rights are divided into classes which place all the pioneers on the same footing. The early priorities are called primary rights; those of later dates are grouped together and called secondary rights. In the other States each appropriation has a separate priority number.

As scarcity of water led to the adoption of the doctrine of priority, the two led to the necessity of defining the quantity of water to which an appropriator should be entitled. While the early appropriators were entitled to protection in their use of water, the later comers had an equal claim to protec- 
tion from an enlargement of those uses. The first appropriator had the first right, but he had not the right to take all the water he might want at any future time. His right must, in justice to others, be defined as to quantity as well as to time. In theory, beneficial use has been made the measure of a right. That is, each appropriator has a right as against a subsequent appropriator to a continued use of whatever quantity of water he had put to a beneficial use at the time of the acquirement of the subsequent right. What constitutes beneficial use, and the determination of the quantity of water so used, has been left to the courts in most States, and their decisions on these points have been the cause of a large part of the controversies over water rights. This, however, is not a fault of the theory, but of its application.

With the adoption of the doctrine of priority the need of providing some notice of the extent of rights already acquired became apparent. Such notice was needed both for the protection of the rights already in existence and as a warning to intending investors, of the extent to which the stream had already been absorbed. The diversion of water without any official record of the time when or place where this was done, led to much confusion and hardship, and it became necessary to determine the priorities and amounts of appropriations. In the absence of official records the facts which govern rights in streams have to be established by testimony. Often this determination 


\section{IRRIGATION INSTITUTIONS}

does not take place for many years after irrigation begins. Many of the eye-witnesses of the early development have disappeared; others are dead; it has also been found that the memory of those actually present is often at fault. Great discrepancies regarding the dates of beginning the work, the sizes of the ditches, and the amounts of water used are the rule rather than the exception in these adjudications. In order to lessen this, if possible, nearly all the States have enacted statutes requiring intending appropriators of water to make some sort of record of what has been done. In States where mining is an important industry the custom of posting notices on lode or placer claims was extended to water-right filings. The laws which require such notices direct persons desiring to appropriate water to post a notice in a conspicuous place at the point of intended diversion, stating the amount of water claimed, the purpose for which it is claimed, the place of intended use, and the means by which it is to be diverted. It also requires that these notices be recorded within a prescribed period, in the office of the county recorder of the county in which the notice is posted. Such laws are in force in Arizona, California, Idaho, Kansas, Montana, Utah, and Washington. The statutes of Colorado and Texas do not require the posting of notices, but provide for the recording of these claims. Such laws were formerly in force in Wyoming and Nebraska, but have been superseded by the issuance of permits by the State authorities, 
and the Colorado law has recently been declared unconstitutional.

In most of the States the laws requiring the filing and posting of notices were enacted after a great many rights to streams had been established, and it was at once realized that a record of water rights which included only such rights as were acquired after the passage of the acts would be of no value, because of its incompleteness. The laws, therefore, provided for the recording of rights acquired before their passage, but with the proviso that a failure to so record a right should not affect its validity. This proviso, which was added to save the law from being declared unconstitutional, has accomplished that purpose, but it has limited its usefulness, since it leaves the records incomplete.

The weakness of these laws is their failure to provide such supervision as will insure that the claims filed shall be accurate or even reasonable, and the absence of any record of the completion of the works. The result is that if the fees are paid any claim presented is recorded. In some sections a book is provided, and any intending appropriator of water goes to that book and writes whatever he chooses, and the clerk attaches his signature. These notices fill hundreds of bulky volumes. Some of them rise to the dignity of curiosities in literature. Examples illustrating their character will be given to show the part they have played in water-right controversies, and the man- 


\section{IRRIGATION INSTITUTIONS}

ner in which they have affected the irrigator's peace of mind. But before this, the requirements of these laws will be briefly considered in order to determine whether the outcome of their operations has been otherwise than might reasonably have been anticipated.

The law says that the appropriator must post his notice in writing in a conspicuous place at the point of intended diversion. Now usually the conspicuous place where the water is diverted is in some willow thicket, or along the cottonwood-bordered banks in some lonesome bend of the stream, where, as has been said by one writer, "only jack-rabbits and coyotes see the notice so posted. Streams are not diverted in the main streets of populous villages, nor even on the main travelled roads of the country." Ditches of any size may have their heads at a considerable distance up-stream from the place where the water is used in irrigation, because sufficient elevation has to be secured to cover the lands to be watered. Hence few people in the neighborhood where the water is used ever see the notices. Even their display in the postoffice, as required in the statutes of Utah, is seen to avail little when one considers the immense area influenced by these claims and the lack of travel across them. From the lowest to the highest ditch on Weber River, in Utah, is a distance of I 50 miles. A conspicuous notice on the Yellowstone River near Livingstone, Montana, is not likely to be seen by appropriators of water from 
the same stream at Miles City, several hundred miles below.

The county records are an improvement over notices so far as publicity is concerned, but they still leave much to be desired. Although public, they are not accessible. The claims to water from the Missouri River in Montana are recorded in fourteen counties. Territorial claims to the North Platte River in Wyoming were recorded in four counties, while appropriations from the South Platte in Colorado are recorded in a larger number of counties. The county seats of many of these counties are not directly connected by railways. To examine all the records affecting a single appropriator's right would often require a week's journey. Hence, while these notices are open to the public, the public seldom sees them. Even with the records before him, a person must be an expert to unearth the facts which they contain. As a rule, the earlier claims are recorded in miscellaneous records; that is, in the volumes devoted to bills of sale, chattel mortgages, mining locations, etc. Sometimes a water filing and a mining location are included in the same document, whose title gives no clew to its contents. A search through these records is usually unavailing.

None of the laws designate how notices shall be posted. Hence they do not have to be attached to monuments as is the case with mining locations. Often the posting is performed by attaching the paper to a convenient tree. Tacks and nails are 


\section{IRRIGATION INSTITUTIONS}

not always at hand. The last notice seen by the writer was fastened on the post of a barbed-wire fence by being hooked over two of the projecting barbs. The locator claimed to have appropriated eight thousand inches. If his statements were true, the property represented by that paper was worth a quarter of a million dollars. Notices like these have no permanence. The wind may tear them from their insecure fastenings a few minutes after they are placed in position. If not blown away or destroyed, the rain will blur or the sun will soon fade the writing into illegibility, but that matters little. The claimant has complied with the law and has no further concern. If the public or any individual fails to see it through lack of publicity or the transient character of the notice, that is not the claimant's fault, but the other man's misfortune.

One notice located the head-gate "somewhere on the western slope of the Big Horn Mountains," which means somewhere within the canyons and defiles of a broken and precipitous tract of country a hundred miles long and twenty miles wide. Another reads as follows: "All persons are hereby notified that the undersigned hereby gives notice that he claims for his own use and benefit all waters flowing within the banks of Wagonhound Creek through his premises, the same being his ranch and range." It might have been possible at the time the notice was posted that a majority of the people along Wagonhound Creek knew 


\section{THE DOCTRINE OF APPROPRIATION}

where the "ranch and range" of the locator were situated, and how far up and down the stream they extended, but to the general public, seeking information in subsequent years, such descriptions are so vague and indefinite as to be worthless. Nor is this an exceptional instance. Statement after statement describes the place of diversion as being where the notice is posted or the place where the appropriator stood. The following examples ${ }^{1}$ from the statements on two streams in California are typical of those which may be found in the records of every arid State:-

We, the undersigned, claim this water from this monument and ditch for 3 miles down this canyon.

At the point above where the road crosses the stream and where the channel is depressed and the banks are steep and precipitous, being about 8 feet high, the right bank being covered with rocks and the left with trees.

The water running in a north and south direction in this canyon.

This notice is posted about 3 miles down the canyon from some three arastras run by steam power, and about 400 yards above an old stamp mill on the same canyon, or creek.

At this point, being a short distance above a large bowlder situated in the bed of the creek.

This notice is posted on a tree just below the water in the canyon.

While in a majority of instances appropriators have done the best they could conveniently to fix the point of intended diversion, it does not help the perplexed searcher to know that the water is appropriated "one-half mile below Watson's sheep

1 Office of Experiment Stations, Bulletin 100. 


\section{IRRIGATION INSTITUTIONS}

camp," or to know that it is taken out of Antelope Creek or Willow Creek, when there are seven Antelope Creeks in a single county in Wyoming, or five Willow Creeks, as is the case in one county in Montana.

The majority of claimants knew nothing of the standards of measurement of flowing water. The miner's inch, the statute inch, the four-inch pressure, and the cubic foot per second conveyed no more idea of the actual quantity of water described than if they had been Sanskrit. Even in cases of corporations, claiming large amounts of water and making large investments, the ignorance of standards is often disagreeably apparent. Every conceivable unit has, at one time or another, been employed. Square inches and square feet of water are often claimed, as well as cubic inches and cubic feet under a four-inch pressure. Claims to immense quantities of water and descriptions of ditches ridiculously inadequate for their diversion are a common feature. In an examination of the records of the San Joaquin River, in California, ${ }^{1}$ Professor Soule found one claim for $3,456,000$ cubic inches under a pressure of four inches, the water to be used for irrigation, navigation, domestic and manufacturing purposes. Another claimed 250 feet of water under a four-inch pressure. Another claimed four square feet of the water of Whiskey Creek measured under a four-inch pressure.

1 Office of Experiment Stations, Bulletin 100, p. 231. 


\section{THE DOCTRINE OF APPROPRIATION}

Speaking of the water-right records of Los Angeles River, California, Professor E. M. Boggs says : ${ }^{1}$ -

Although the claimants were usually most liberal to themselves, wording their claims in phrases broad enough to cover all future contingencies, instances are numerous in which the notices show that they had no adequate conception of the quantity of water claimed, or the carrying capacity of the specified conduit. One proposed to divert 200 inches by means of an iron pipe 2 inches in diameter for the first 40 feet, then one inch to the place of intended use. Another claims 3000 inches of water under a four-inch pressure, to be taken out in a pipe $1 \frac{1}{2}$ inches in diameter. The performance of this feat would require the water to pass through the $\mathbf{I} \frac{1}{2}$-inch pipe at the rate of about $\mathrm{I}$ mile a second, or about three times the velocity of a rifle-bullet. One claimed, "All the water amounting to 150 inches of hydraulic pressure and 4-feet measurement." Another notice reads: "The undersigned claims 4 feet of water from under a 4 -inch pressure." Another: "To the extent of 100 square inches miner's measurement." Still another: "I00,000,000 cubic feet." One prudent and far-sighted man, after claiming a liberal flow of water and describing the ordinary means of diverting the same, provides for the emergency of future dry years by adding: "I also claim the right to hand or pack from here to said ranch in case of drouth or too little to run down."

The wording of recorded claims shows that as time went on men attached more and more importance to these records. It is evident that at first the belief prevailed that beneficial use was the measure of a right, but later, especially after a few adjudications of rights had been made and decrees had been rendered to many times the amount in

1 Office of Experiment Stations, Bulletin 100, p. 334. 
actual use, a large number of appropriators came to believe that it was not the amount of water used but the amount of water filed upon which governed; and that, while it might not be that a written record was alone necessary to secure a water right, it was by far the most important step. With the acceptance of this idea claims began to take on speculative character, and claims to excessive volumes of water began to be not simply numerous, but the most conspicuous feature of the records.

The records of one stream show that all of the earlier claims were for small volumes, varying from one cubic foot per second to five cubic feet per second. These were probably a close approximation to the actual needs of the claimants; but a change in the policy of claimants was marked when one appropriator, desiring to secure the surplus water-supply for future consumption or sale, claimed 300 cubic feet per second. This was more than twice the water carried by the stream, but every claim which followed was for 300 cubic feet per second. The records of Boise River, in Idaho, show I 5 I claims, amounting in the aggregate to $6,36 \mathrm{I}, 800$ inches. The actual flow of the river in September, I898, was 35,000 inches. On a little stream in Wyoming, which usually goes dry in August, there is a claim for 60,000 cubic feet of water per second, enough to irrigate $6,000,000$ acres of land. The filing of this claim does not indicate that the appropriator thought he 


\section{THE DOCTRINE OF APPROPRIATION}

could irrigate $6,000,000$ acres. He had no real understanding of what he was claiming or what the stream carried. A great many appropriators have saved themselves the labor of fixing upon a specified amount by claiming all the water in the stream. One of the absurdities of these records is to find in succession a series of statements that the claimant has appropriated and taken for his own use and benefit the entire water-supply. It of ten happens that the claims against a river amount to less than those against some of its tributaries. Nor are all of the claims excessive. Excessive claims may be followed by others which claim less rather than more than the actual volume used.

The law says that the appropriation must be for some useful or beneficial purpose. Recognizing this, it has been claimed for every conceivable purpose to which it could be applied, and the uses stated in the notices have changed from time to time as the demand for water for different purposes has arisen. At the outset, agricultural and domestic uses were usually specified, except in mineral districts, where mining was the use most commonly stated. Later on, as cities and towns sprang up and water for domestic use and manufacturing purposes became more important, these have been added, and still later the utilization of water for the generation of electricity has caused that item to be included in all of the comprehensive claims. One appropriator describes the beneficial uses to which the water is to be applied as "irriga- 


\section{IRRIGATION INSTITUTIONS}

tion, motive, and mining, and for supplying cities, towns and villages," and then, fearing that his ingenuity in discovering uses was hardly equal to the occasion, added, "such appropriation to be exercised as circumstances may require." Another described the beneficial use intended as "irrigation and such other uses as I may deem proper." Another: "Power, irrigation, domestic, stock, agricultural, mechanical, commercial and importation." Another ended his record with this: "And John Brown further declares that he appropriated and took said water, together with all and singly the hereditaments and appurtenances thereunto belonging or appertaining or to accrue to the same." Just what the hereditaments and appurtenances of running water might be was left for the other appropriators to ascertain.

A land system which would permit of a score of filings on the same quarter-section, and then leave the claimants to fight for its possession, would not be held in high esteem. The law for recording appropriations of water which places no restrictions on the number or volume of these claims is just as illogical, and is fraught with more serious evil. To say the least, these records are of little value. The clerk or the recorder has to write down whatever is submitted. He has no means of knowing whether a new claim is in accordance with facts, whether a projected work will be carried out, or if it will be a public benefit. No means is provided for ascertaining if the claims recorded have been 


\section{THE DOCTRINE OF APPROPRIATION}

followed by construction. No provision is made for measuring the flow of streams, in order to know if the amount appropriated is equal to or in excess of the supply. The law says that the appropriation must be made for a useful or beneficial purpose, but it goes no farther. It provides no methods by which the public may ascertain promptly and inexpensively whether the amount taken out is the amount to which claim was laid, whether it has been applied beneficially or not applied at all. If the claimant proceeds diligently and uninterruptedly with construction and uses the water as described in his notice, he is entitled to the right thereby acquired, and it should be protected without cost to him. On the other hand, if a claim is not completed in accordance with statements of the notice, if the water claimed is not all used or not used in the manner specified, it is equally important that the records show these facts. Unfortunately, the completion of appropriations in accordance with the statements of claims is the exception rather than the rule, in which case the recorded notices are false and misleading and in time acquire a force and standing to which they are not entitled.

In some cases it is also apparent that compliance with the statute was perfunctory, and many who were seeming to fulfil the letter of the law were equally anxious to evade its spirit. Many also objected to recording their claims. They had little faith in the value of documentary records. They 
believed that the open, notorious use of water was all that was necessary to procure and preserve their rights, and there are to-day on nearly every stream of any importance many old rights of which there is no record whatever. The records are as uncertain in what they omit as in what they contain.

The filing of these claims does not give complete title to water. In all of the States except Wyoming, Nebraska, and Nevada, this has to be established by litigation in the courts. Sometimes these lawsuits take the form of injunctions, sometimes equitable actions to determine the respective rights of appropriators or to quiet their titles. But whatever their form, they all have one thing in common: they are waged as though the issue were purely a private matter, and the disposal of the rains and snows that make streams were something in which the public had no concern. There is no disinterested or public measurement of the ditches and streams or of the lands irrigated. The testimony submitted is often inaccurate and contradictory, but it is all the judge has on which to base his decree. Even the government, as the owner of large areas of land requiring irrigation, is never a party to these suits, nor is the State, although nothing so vitally concerns the public welfare as the establishment of ownership or control over streams. One of the results of this lack of public investigation of actual conditions has been the granting of extravagant rights to water. The excesses in this line have been almost as marked as 
in the filing of claims. In some instances appropriators have agreed among themselves as to the share of the stream which each would claim in court, and, as they furnished the testimony, there was little difficulty in securing a decree in accordance with this agreement, the court being either an unconscious or helpless instrument for giving legal sanction to a fiction if not a fraud. In some cases these excessive decrees have not stopped with giving away all the actual water-supply, but grant rights to many times this volume.

The early practice was to give a right to divert water all the time. Experience has shown that this leads to abuses, because it does not agree with the way irrigators use water. Continuous irrigation would be as injurious as a continuous rain. No farmer irrigates all the time; few farmers irrigate half the time. Some irrigate in winter and grow crops with the moisture stored up in the soil. In some sections water runs in the ditches less than a hundred days. In a recent report of the Irrigation Investigations of the Office of Experiment Stations, United States Department of Agriculture, the records of sixty farmers in one State showed that the average farmer used water less than three weeks in the year. Some farmers used water only one week, and scarcely any of them more than one hundred days. In districts where irrigation extends from April to October, the use of water by individual farmers is intermittent, determined largely by the local rainfall for the season 


\section{IRRIGATION INSTITUTIONS}

and the kind of crops grown, hence a right to a continuous flow gives control of a water-supply for long periods when a single irrigator has no use for it.

As the demands upon the water-supply have grown, necessity has led to a gradual decrease in the freedom of the appropriator and an increase in the control exercised by the public authorities. This change has been so gradual that the legislatures of Wyoming and Nebraska have in effect abandoned the doctrine of appropriation, although retaining the word in their statutes. The person wishing to use water must secure a permit from a board of State officials, and the right acquired is not governed by the appropriator's claim, but by the license for the diversion issued by the State authorities. This tendency toward public supervision is manifest in the other arid States, and it seems only a question of time when the doctrine of appropriation will give way to complete public supervision. The law of Wyoming, the pioneer in this new system, is discussed in a succeeding chapter.

Some of the early discussions of water rights have been preserved. They show that each irrigator favored the doctrine which promised the most water for his ditch or farm. Some believed there should be the same property right in water as in the land to which the water was applied. This would impress on streams the same sort of ownership which exists in corn, wheat, live stock, 
or any other form of personal property. Others believed that an appropriation of water gave only a right to its use, and that when the use ceased the right ceased. The distinction between the two doctrines seemed to many to be immaterial. What the irrigator wanted was to be sure of his share in the stream whenever he needed it, and of protection against the encroachments of later comers. When the first water rights were established, the appropriators were, as a rule, actual users of the water appropriated. The owner of a farm owned the ditch which watered it, and it was of little practical consequence to him whether he acquired his water right as a ditch-owner or as a landowner, whether he held it as personal property or as an easement attached to the lands irrigated. It was the belief of the Mormon leaders that rights to water should be inseparable from the land on which it is used. In I 86I Colorado enacted a water law which was reënacted in Wyoming in 1876 , under which rights were attached to land.

The discussion which preceded the framing and passage of the Colorado irrigation law in 1879 was largely devoted to the nature of rights to water which should be recognized. All were agreed that these rights should be attached to either the land or the ditches. Those who favored making rights to water inseparable from the land where it was used pointed out that this would prevent speculative ownership of streams, or the granting of excessive amounts of water by the courts, because the needs 
of the land would always serve to measure its share in the stream, and that these rights, instead of being enlarged as time went on, would become smaller because, as the subsoil became filled, less water would be needed and more of the stream left for irrigators with later rights. At the same time, this doctrine would work no hardship to earlier users, because it would provide them with all the water their land needed. The advocates of this policy were able to fortify their argument by showing that it was in accord with the experience of southern Europe. The law, however, was framed on the theory that rights to water should belong to the ditches, and be based on their estimated capacity rather than on the needs of the land. This plan was adopted because it seemed simpler than the other. Those who favored it pointed out that giving to each ditch a certain volume of water flowing all the time would make it easier for a water commissioner to divide the stream. If he was given a list of the ditches and of the volume of water belonging to each, all he would have to do would be to regulate the headgates in such a way as to see that this quantity was turned in. If, on the other hand, rights were based on the needs of the land irrigated, it would require constant oversight to determine how much water was being used, and constant change in the amount of water turned into each ditch. The owners of large canals built by corporations to furnish water to farmers rather than to use it 
themselves, naturally favored making the ditch the appropriator rather than the land. It added to the security and value of their investments to own the commodity they were distributing and be able to fix both the price and conditions of its disposal. The owners of these canals were, as a rule, men of shrewdness and foresight. They had the leisure to study the economic import of the waterright doctrines under discussion, and understood the value of laws which would give them control of the water diverted. The irrigators, on the other hand, gave little heed to the subject. They were busy ploughing their fields, planting their crops, and learning the methods of a new industry. The tendency to make the ditch the appropriator was strengthened by the fact that water rights were to be established by litigation. The desire of farmers is to keep out of lawsuits. They have neither the means nor the disposition to engage in them. The owners of large irrigation enterprises, on the other hand, employed able legal counsel to frame their water-right contracts and to look after their inter. ests in the courts. It was to the supposed interests of their clients to have the appropriation go to the ditch-owner, and in this way it gradually came about that many of the ablest attorneys of the West were retained or enlisted in favor of this policy.

Many who have received rights to a perpetual flow find that the ability to rent or sell the right to other users during the period of their non-use, 
is more valuable than their own use of the water. Especially is this true on streams where more land is cultivated than can be thoroughly watered. The holders of inferior rights live in fear of drouth, and are willing to pay high prices for the surplus of the earlier appropriations. The tendency to augment the influence and value of early priorities is becoming more manifest every year. The owners of large appropriations are applying them to new lands and extending their influence far beyond the limits of the land originally irrigated. Sales of water rights to irrigators are made under contracts which make the inch of water supplied to one farmer this week, serve another farmer the following week, and a different farmer the third week, so that the inch, instead of irrigating one acre for one man, irrigates one acre each for three men. There are other ditches which can irrigate only limited areas, yet have appropriations to ten or twenty times the volume needed. In some States the owners of these surplus rights sell or rent them to other ditch-owners or to irrigators on other lands. As the years go on, the value of these rights is assuming fabulous proportions. The rights to City Creek, Utah, the first stream diverted by the Mormons, are now worth $\$ 1,600,000$, exclusive of either the land or ditches where the water was first used.

The speculative value of the personal ownership of running water is so great that every argument which the ingenuity and intellect can produce has 
been presented to the courts in its favor. That it is opposed to public welfare, that it places users at the mercy of appropriators, is not a matter of theory, but of experience. Every objection which has ever been urged against the granting of free and unlimited franchises to the public utilities of cities applies with greater force to giving away the water of Western streams. Nevertheless, city councils continue to grant such franchises, and speculative titles to water continue to be declared vested. The cause is the same in both cases. Organized selfishness is more potent than unorganized consideration for the public interests. The appropriator has been in court in person and by attorney. The rights of the water-user apart from the ditch-owner have seldom been considered. Hence it is coming to be, that rights to running water are ceasing to conform to the requirements of any use, are being separated from any place of diversion or application, and are being bought and sold and leased like land or live stock or any other property. 


\section{CHAPTER V}

\section{Contract Water Rights}

WHERE ditch companies appropriate the water of streams and sell rights in these appropriations to farmers, the rights of the irrigator are determined by his contract with the company. These private water contracts have, in many instances, more influence over the watering of farms than the State irrigation code, because of their number and the large acreage of irrigated land which they represent. One canal company has an appropriation from the South Platte River which will more than supply 1000 eighty-acre farms. Another company has an appropriation larger than the average flow of the Poudre River. Five hundred farms in Idaho are supplied from the appropriation of a single canal company, and the contracts of another canal company govern the distribution of water to over 100,000 acres of land, and the lawns and gardens of two thriving towns.

The control over irrigation exercised by these private contracts has received small consideration, either in current discussions or court decisions. Wherever water rights are referred to, it is assumed that they are the direct outcome of State irrigation codes, and that all the privileges conferred 
by State laws are enjoyed by irrigators. This would be true if the water rights were attached to the land or were acquired by the users of water. It would also be true if the companies which have appropriated streams had in their contracts or deeds conferred on farmers all the privileges they acquired. This is not the case, however. The sale of a water right by a ditch company rarely carries with it a share in the original appropriation. The water right sold is hedged about with restrictions and stipulations, and varies so widely from the original grant as to make contract water rights a distinct factor in irrigation development and as worthy of study as the State laws themselves.

While contracts vary widely in detail, they can be classified into three general divisions :-

(I) Those under which water is furnished for a stipulated annual rental.

(2) Those providing for the sale of perpetual rights for a fixed sum, with the addition of an annual charge for operation and maintenance of irrigation works.

(3) Those providing for the sale of an interest in the canal and the appropriation, accompanied by conditions governing the operation of the canal until it is turned over to the shareholders.

\section{(I) Annual Water Rentals}

The plan most favored at first by irrigation companies was to furnish farmers the water they needed at so much a year, as dwellers in cities are 
furnished water for domestic uses by municipal water companies. This plan has proven unsatisfactory because, as irrigation companies found to their sorrow, they were dealing with human nature as well as the needs of the arid lands. Nearly all of their customers were from the humid East, where their fields had been watered from the clouds for nothing. They had an inherited prejudice against paying for what the clouds had supplied without cost, and were inclined to look at any charge for water as exorbitant; hence contests over water rents soon arose. In some cases they had a just foundation for contest in excessive rentals. In others the unrest and dissatisfaction were due to their dependent condition. Although they owned the land, they could grow nothing on it without the aid of the canal company, and they saw before them the danger of having to pay such rentals as would absorb all the profits of their industry. This fear of future evils rather than of present ones often provoked a spirit of hostility toward canal companies and led ultimately to a general abandonment of the plan of furnishing water under yearly contracts.

Without any disposition to be unfair on the part of either farmer or ditch company, there is ample reason for an honest difference of opinion as to what is a reasonable rental. Ditch-owners believe that water rates should be high enough to pay an interest on their investment, while to farmers, rentals, to be reasonable, must be low enough to 
enable them to cultivate their land at a profit. In many instances, rentals that would pay interest on the bonds and stocks of the ditch company would bankrupt farmers. One ditch company which supplies water to 10,000 acres of land has expended $\$ 1,600,000$ in the construction of its canal, and has to pay from $\$ 10,000$ to $\$ 20,000$ a year to keep it in repair. Six per cent interest on the investment would be $\$ 96,000$. Adding $\$ 15,000$ for operating expenses makes it necessary for the farmers to pay $\$$ III,000 in water rentals to make this enterprise self-supporting. This would be over $\$$ I I an acre - a prohibitive price. The farmers are poor; their lands are unimproved, and they have a heavy outlay in building laterals, farm buildings and fences, and are not able to pay over $\$ 2.50$ per acre for the water they use. This is the largest price they have paid, and as a result the ditch company has been unable to pay interest on its securities, and can barely meet its operating expenses. The annual interest on the bonds of the W. D. Company is $\$ 45,000$, and the expense of maintaining the canal $\$ 20,000$ a year, making in all $\$ 65,000$, which the farmers must pay in water rentals to make the enterprise self-supporting. The canal furnishes water to 20,000 acres of land. A reasonable rental from the standpoint of a ditch company would at least pay the interest on their bonds and the operating expenses of the ditch; but to pay $\$ 3$ an acre for water would drive every farmer under the canal into bankruptcy. 


\section{IRRIGATION INSTITUTIONS}

In controversies over rates the farmers are at an advantage. They are on the ground. Their greater number gives them a local influence far more potent than that of the canal company, which is often a foreign corporation, and the object of local prejudice because of this. Legislation for fixing water rentals by local boards has been enacted in nearly every arid State. If this legislation had been properly guarded, it would have been of great service. There is need of some means of arbitration by which long and expensive litigation may be averted, but such arbitration to be just and satisfactory must be impartial and in the hands of experienced and competent men. Unfortunately, the laws do not provide proper tribunals. In nearly every case the settlement of these questions has been intrusted to boards of county commissioners or supervisors. As these supervisors are elected to perform other duties, they rarely have either the time or expert knowledge needed to reach a just conclusion.

In one contest of this kind the annual rental fixed was 20 cents per acre. This would not pay the expenses of the ditch superintendent, to say nothing of the interest on the cost of the canal, which was $\$ 220,000$. After operating at a loss for several years and seeing no hope of better results, the builders abandoned this canal, and it fell into the possession of the settlers. The expenses of the operation alone for the first year were $\$ 1.20$ an acre, or six times the rate fixed by the supervisors. 


\section{CONTRACT WATER RIGHTS}

\section{(2) Sale of Perpetual Rights to Water}

The number of companies which furnish water on the payment of an annual rental is far less than the number of those which dispose of water by the sale of perpetual rights. The plan of such companies is to sell perpetual rights enough to repay the cost of construction, and make annual assessments to pay the cost of operation and maintenance. It has been the prevailing practice of such companies to begin selling rights before there has been any judicial or other determination of the priority or amount of their rights, and sometimes before the canal is constructed, the rights which they sell having no foundation but a claim of an appropriation equal to the capacity of their works. The payment for such a perpetual right is not a payment for water, nor for an interest in the canal, but for a right to obtain water through the canal. Theoretically, the right of the canal company is based on a beneficial use of the water, and this use must be made by the purchaser. The canal company is, therefore, selling something which it does not possess, and having sold it still retains all that it had before such sale, - its canal, the ownership of the water it carries, and the right to operate it.

A modification of this plan provides that when a certain number of rights are sold, the works shall be turned over to the holders of the rights, and stock in a new company issued in place of the old 
rights, the canal to be the property of the new company. In such a case the charge for water rights is made large enough to repay all outlay and a profit on the enterprise. The purchaser gets an inchoate interest in the canal, which is to become effective at some indefinite future date.

Owing to a failure, before beginning work, to study the character of the water-supply and the prior rights to its use, and owing to the inability to obtain definite information on this subject, many canals have been built which have no warrant for their existence. Their appropriations of water are practically worthless because the stream is controlled by earlier rights. It is often years before the managers of these enterprises understand this situation themselves. In the meantime settlers are occupying the land below ditches which in time will be absolutely dry during a large part of the year. As a rule, purchasers of these rights know nothing of the irrigation laws and do not realize the difference between the value of an early and a late priority. They are more influenced by the character of the land and the terms of the canal companies' contracts than by anything they learn of water titles. As a result, many a farmer has lost the savings of years in the purchase of rights in paper appropriations. They have a title to water in the records of the court-house, but no share in the supply of the stream. The fact that builders of these works were often as ignorant of the dangers before them as those to whom they 


\section{CONTRACT WATER RIGHTS}

gave deeds to water, alone prevents these transactions from being fraudulent.

Farmers prefer, as a rule, purchasing perpetual water rights to securing it on an annual rental. There is an agreeable sound about the ownership of a perpetual right. It gives the possessor a feeling of security, especially if he is from the East and does not know how little this signifies. A deed to a perpetual right seems a security against all future contingencies. As a rule, these deeds provide in addition that the company shall keep the canal in good order and repair, so he not only secures what seems to be a right to water, but a guarantee of its delivery. The conditions and reservations which so vitally affect this instrument and the uncertainty about the ownership of the water apparently conveyed are all matters which are brought later to his attention.

Where the conditions of these water deeds are equitable, where the farmer receives as much consideration as the ditch company, and where the contracts are based on an ample water-supply, there is seldom any complaint or controversy, but in some instances the contracts are exceedingly arbitrary and unjust to the farmer. Such contracts have not, in the long run, worked to the advantage of ditch companies. Where the provisions are too severe the farmer will not sign them, or, if he does, he is always in a state of unrest and rebellion. One stipulation, found in nearly all these contracts, is that the company will not be responsible for a 


\section{IRRIGATION INSTITUTIONS}

shortage occasioned by drouth or acts of Providence. Another is that in times of scarcity the water which is available shall be divided pro rata among the holders of water contracts. Few canals carry their full capacity for more than a few days during the season and what the purchaser really buys is not a right to a fixed volume of water but a right to a share in whatever the canal can furnish. The number of water rights sold from each canal, therefore, has almost as much to do with the farmer's supply as the volume appropriated from the stream. Many contracts contain the following: "It is agreed that the number of water rights that may be sold from the ditch shall be based not upon present decrees granted nor upon any decrees that may be granted to said ditch, but upon the estimated practical capacity of said ditch system." Under this agreement the company may build a canal for which there is no possible watersupply and sell rights up to its full estimated capacity, and still be relieved from any liability for damages.

Some of the distinctions between the rights of farmers under existing contracts and what they would be were the farmers the appropriators, are pointed out below. These vary somewhat with different contracts, but are, as a rule, matters of minor detail. An examination of hundreds of these contracts shows that in their essential features they have a surprisingly close agreement. If their stipulations are compared with the laws gov- 
erning appropriations in all except three States, they will show these differences :-

The party who builds a ditch is not restricted in the place where he may use the water he thereby acquires. He may apply it to one tract of land one year and to another tract of land the succeeding year, and sell it to turn the wheels of a factory the third year. In making these changes he does not have to ask the approval of the State authorities nor comply with any legal formalities. It is not so with the user of water. When he purchases a perpetual water right he is given no such freedom. His contract always describes the land where the water is to be used, and he cannot change it from that land without the consent of the ditch company.

The canal owner acquires a right to a continuous flow. In very few decrees is there any limitation imposed on the time of diversion. The courts have over and over again held that the right to a continuous flow is vested, and if the appropriator does not need the water himself he can sell it or rent it to others. But the farmer who has to buy the water he needs does not meet with such liberality. In hundreds of contracts examined the length of the irrigation period is always stipulated. The irrigator is required to close his head-gate when the water is not needed, and in some cases the appropriator reserves the privilege of determining whether water is being used with proper economy and skill. 
In nearly every instance the maximum amount of water which will be allowed an acre of land is stipulated in the contracts, and the duty thus assumed is nearly always higher than the duty assumed in court decrees.

These contrasts have not been pointed out for the purpose of criticising the contracts. Exactly the reverse is true. Experience has shown the value of the limitations imposed: they work no hardship to the irrigator, and should have been applied to the original appropriations. If the irrigator who obtains his water-supply under a contract has his right attached to a specific tract of land, why should not the original appropriation be so attached? If an irrigator has to close his headgate when water is not needed, why should the original appropriator be given a right to a continuous flow?

\section{(3) Coopperative Canals}

The latest phase of irrigation development by corporate capital has been the building of canals to sell outright to settlers just as houses are built to sell to the dwellers in cities and towns. As a rule, these canals are operated for a time by their builders, but are turned over to irrigators to be managed by them as coöperative enterprises as soon as a certain number of shares has been sold.

The most successful irrigation works in California and in a number of Western States belong 


\section{CONTRACT WATER RIGHTS}

in this class. All of the canals built in Wyoming and Idaho, under the provisions of the Carey Act, have to be sold outright to settlers, so that the landowner is also a ditch-owner and arranges for his water rights with the State authorities. 


\section{CHAPTER VI}

\section{Measurement of Water}

THE distribution of water for irrigation is attended by many perplexing conditions. Streams vary in volume from day to day. Wells which cannot be lowered in April often fail in August. The watersupply is subject to continued waste and loss. It sinks through the bottom of canals by seepage, and is taken up by the air through evaporation.

When the supply was abundant and the acreage limited, these vicissitudes were of small importance, but with the growing use of water, changes in methods and policies are necessary. This is especially true regarding the care taken in its measurement, and in the attention now being paid to the contracts under which it is supplied to irrigators. When streams carried more than was needed, water was seldom measured. Canal companies took what they wanted, and the irrigator was charged for the acres irrigated without any reference to how much he used. This was like furnishing a family with groceries at so much per head, without any limit on the quantity consumed or wasted. The results of this lavishness do not warrant its continuance. It led farmers to substitute water for cultivation, and to injure their land and exhaust 
streams by wasteful and careless methods. The need of a definite unit of measurement for the commodity bought and sold is now manifest. Without this there can be no satisfactory basis for transactions in water, or any intelligent or certain measure of value for irrigation properties.

In the establishment of such unit several things have to be taken into account. It should be in accordance with the requirements of agriculture, so that the quantities to be measured can be regulated by simple and not too costly devices, and be stated in a unit convenient of computation. Any unit, to be generally adapted and enforced, has to be both feasible in operation and in accord with the needs or prejudices of water users. Water cannot be delivered to irrigators by the pound or ton. Measuring water to irrigators in gallons would be like selling coal to railroads by the ounce.

Three units of measurement are now in general use, and some one of these three is recognized in the laws of nearly every arid State, and is nearly always stipulated in water contracts. They are the inch, the cubic foot per second, and the acre-foot.

In the measurement of water for irrigation there are two distinct principles involved which it is desirable to have clearly defined and to keep separate in the mind. The first is the unit of volume to be employed, wholly apart from the method by which this unit may be measured in actual practice. Thus, in irrigation, if we say that the unit of measure is the cubic foot per second, the character and volume 
of the unit are not affected whether water is measured by the flow over a weir or through a flume, or by the strokes of a pumping engine. The unit may sometimes be the quantity of water which issues from an opening of fixed dimensions, with or without pressure, or the unit may be the acres of land irrigated under certain conditions.

\section{The Inch}

In some cases, however, the unit of measurement is associated with a special device or instrument by which it is to be actually determined. The form of this apparatus should be in accord with the principles of hydraulics, and be determined by scientific considerations. "The inch" is such a unit of measurement; it has to be associated with some particular device or instrument of measurement. Its use is as old as irrigation. In this country it is older than modern irrigation, having been first used by the placer miner and borrowed from him by the irrigator. In both mining and irrigation it is the volume of water which will flow through an inch-square orifice under a uniform and designated pressure. The shape and size of the orifice and the pressure upon it are fixed by law in a number of States, and in others regulated by custom.

The ruling custom in the United States is to have the orifice through which water is delivered 6 inches in height and wide enough to deliver the required number of inches. The pressure on this 
orifice varies from 4 inches above the centre in some places to 6 inches above the top in others. In Nevada the inch has sometimes an opening 4 inches in height, with a pressure of 6 inches above the top.

Water sold by the inch by any individual or corporation shall be measured as follows, to wit: Every inch shall be considered equal to an inch-square orifice under a five-inch pressure, and a five-inch pressure shall be from the top of the orifice of the box put into the banks of the ditch, to the surface of the water; said boxes, or any slot or aperture through which such water may be measured, shall in all cases be six inches perpendicular, inside measurement, except boxes delivering less than twelve inches, which may be square, with or without slides; all slides for the same shall move horizontally and not otherwise ; and said box put into the banks of ditch shall have a descending grade from the water in ditch of not less than one-eighth of an inch to the foot. - (General Statutes of Colorado, 1883, Sec. 3472.)

Irrigators who are not able to compute the quantity of water flowing over weirs or through flumes as a rule prefer to have their water measured by the inch. They can tell by looking, or believe they can, whether or not the quantity contracted for is being delivered, and where the conditions prescribed by the statute, as given in the law quoted, are complied with, they can tell with a close approximation to the truth whether or not they get what they pay for.

The most serious objection to this unit is the name. Men accustomed to square inches and 
cubic inches confuse these with miner's and statute inches. Because of this confusion, they frequently determine the inches of water being furnished them by ascertaining the number of square inches in the cross-section of their ditch or lateral, and calling this the number of inches of water received, although in doing so they disregard both the absence of an orifice, the pressure

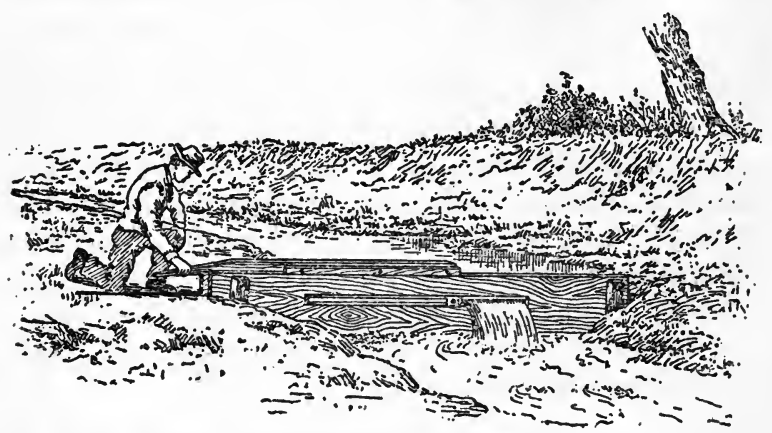

FIG. I. - Measuring Stream by Miner's Inch.

upon it, and the grade or velocity of the stream measured.

It is the common practice on many streams in Utah for the water masters to measure the inches of water in the ditches by taking the cross-section of their flow and wholly disregarding pressure and velocity. A territorial water law, - now repealed, - in defining how water should be measured, described the inch in one paragraph as a cubic inch and in a succeeding paragraph as a miner's inch. 
A simple device for measuring miner's inches is shown in Fig. I. The illustration represents a board 2 inches thick, 12 inches wide, and about 8 feet long. The opening is $\mathrm{I}$ inch wide and 50 inches long, and the distance from the top of the board to the centre of the opening is exactly 4 inches on the up-stream side. On the down-stream side the opening is bevelled so that the hole presents sharp edges to the stream. A sliding board is hung upon the top of the first board with a strip screwed along its upper edge, this sliding board being wide enough to cover the opening on the up-stream side. In the slot there is a closely fitting block made to slide on the bevelled edges and fastened by a screw to the sliding board. When the sliding board is moved backward or forward, by means of its end, which is extended for a handle, the block moves in the slot and determines the length of the opening.

When used to determine the flow of a stream, the board is placed as shown in the figure, so as to dam the flow completely, and the sliding board is moved backward or forward until the water is all passing through the slot, the water being kept to the top of the board, or 4 inches above the centre of the opening. The length of the opening measures the number of miner's inches of water flowing through. If the flow is too great to pass through the opening I inch wide, the opening may be made wider, the water still to be kept 4 inches above the centre of the opening. 
Many measuring boxes on European canals are constructed in the most substantial manner of masonry. The orifice is cut through stone, with edges of metal, and with the utmost precision in its dimensions. Thus far, in this country, but little attention has been paid to accuracy, either in the form or size of openings, although much ingenuity has been shown in designing automatic regulators. The prevailing practice in the West is to make the measuring boxes of wood, and to give slight regard either to the freedom of delivery or to securing uniform pressure. One of the reasons why no more consideration has been given to the accuracy of measuring devices is the fact that the conditions of water contracts are so often not in accord with the way water has to be used.

The field of usefulness of the inch is restricted to the measurement of comparatively small quantities of water. It is well adapted to the distribution of water to irrigators from canals, or from the main laterals of canals, but it is not suited to the measurement of rivers or to the distribution of water from a river. Where large volumes, or widely fluctuating volumes, are to be measured, the construction of a satisfactory device for measuring by inches is not practical. There are a number of canals in this country which carry from 50,000 to 125,000 statutory inches. It is manifest that while the width of an orifice can be extended indefinitely, without materially affecting the ac- 
curacy of the measurement, every change in its depth must materially increase the velocity, and hence the quantity of water discharged by each square inch of its cross-section. Nearly all of the statutes prescribe a maximum depth for the orifice, and require that increase in volume delivered shall be secured by extending its length. To measure the water required to fill the Del Norte Canal, under the conditions prescribed by the Colorado Statute, would require an opening 1736 feet in length, which would be practically impossible.

The limitations of mechanical devices render the inch unsuited to measuring the flow of rivers. In States where the inch is recognized as the legal unit in the distribution of water among irrigators, some other has to be employed in the measurement of the flow of streams.

\section{Cubic Foot per Second}

The cubic foot per second has come into general use as the unit of volume for gauging and dividing rivers, and in measuring the flow of ditches and canals. Nearly all of the arid States and Territories have made it the legal unit in water contracts and for defining the amounts of appropriations from streams. It has the double advantage of precision in statement, of being well adapted to the measurement of large as well as small volumes of flowing water, and of permitting the employment of varied methods of measurement. In 
many States it is used in connection with the inch. The flow of the stream and the amounts of appropriations are stated in cubic feet per second. The water, after it is turned into ditches, is measured out to farmers in inches. This renders it desirable that there should be some basis of comparison, some legally defined ratio between the inch and the cubic foot per second.

A number of States have passed laws fixing the number of inches which equal a cubic foot per second. ${ }^{1}$ Legislation fixing this ratio has been of decided service in the States where the inch is still employed.

The following is the ratio assumed by law or custom in a number of States :-

Colorado, one cubic foot per second equals 38.4 statute inches Montana, one cubic foot per second equals 40 statute inches Idaho, one cubic foot per second equals 50 miner's inches Arizona, one cubic foot per second equals 40 miner's inches Nevada, one cubic foot per second equals 50 miner's inches Utah, one cubic foot per second equals 50 miner's inches

In many places the inch is retained as a term where it has no existence in fact. The farmers who have been accustomed to estimating the flow of water in inches find it hard to think of this flow in cubic feet per second. Because of this engineers

1 Statutes of California (approved March 23, I90r), Sec. I. The standard miner's inch of water shall be equivalent or equal to one and one-half cubic feet of water per minute, measured through any aperture or orifice. 
who measure the flow of ditches or canals in cubic feet per second convert this into inches according to the statutory ratio. On many ditches where the inch is still retained as the unit of measurement there is no measuring box for its delivery. Farmers pay for their water-supply in inches, and estimate the flow in their laterals. Where the water is measured, the volume is determined in cubic feet per second and converted into inches on some arbitrary ratio. The real unit is the cubic foot per second.

\section{The Acre-foot}

The inch and the cubic foot per second are units of volume of flowing water. When the flow of a stream can be stored and the water can be used as desired, the aggregate discharge and the total requirements of crops must be ascertained, and a unit of quantity is needed. This has led to the adoption of the acre-foot as a unit of measurement. It is the quantity of water required to cover an acre to a depth of one foot, or 43,560 cubic feet. The discharge of a stream in cubic feet per second is easily convertible into acre-feet, since one cubic foot per second flowing constantly for 24 hours equals approximately 2 acre-feet. 


\section{IRRIGATION INSTITUTIONS}

\section{The Irrigating Stream}

The "irrigating stream" is a unit in common use in Utah. It is a stream which one man can control to advantage, but no rules for its measurement have ever been prescribed. The size of the stream is left to the water masters, who are charged with distributing water to the farmers. The following extract from a notice sent out by a Utah canal company illustrates the use of this unit:-

"Each share of stock will entitle the owner to the use of what is commonly called 'an irrigating stream,' for seventeen hours.

"The books of the company show that you are the owner of shares of stock, and you will therefore be entitled to the use of an 'irrigating stream ' for hours."

The water in this canal is not measured, nor are the diversions. The water master estimates the number of "streams" in his canal, and these streams are used in turn by the farmers. They are supposed to be equal, but the measurements given in the following table show how far they come from being so. These measurements were made to determine the accuracy of the judgment. of the water master. Some of the laterals measured were carrying more than one stream, but in the table all have been reduced to the same basis for convenience in comparison :- 
MEASUREMENT OF WATER

Measurement of Water delivered by Canals in UTAH, JULY I7, 1900

\begin{tabular}{|c|c|c|c|}
\hline \multicolumn{2}{|c|}{ Canal No. I } & \multicolumn{2}{|c|}{ Canal No. 2} \\
\hline $\begin{array}{l}\text { Number of shares } \\
\text { represented by } \\
\text { water delivered }\end{array}$ & $\begin{array}{l}\text { Quantity of water } \\
\text { flowing through } \\
\text { orifice }\end{array}$ & $\begin{array}{l}\text { Number of shares } \\
\text { represented by } \\
\text { water delivered }\end{array}$ & $\begin{array}{l}\text { Quantity of water } \\
\text { flowing through } \\
\text { orifice }\end{array}$ \\
\hline & Cu. ft. per sec. & & Cu. ft. per sec. \\
\hline I & I. 96 & $\mathbf{I}$ & 1.40 \\
\hline $\mathbf{I}$ & 2.02 & $\mathbf{I}$ & .89 \\
\hline $\mathbf{I}$ & 3.12 & $\mathbf{I}$ & 1.52 \\
\hline I & 1.89 & $\mathbf{I}$ & 1.03 \\
\hline I & I. 78 & I & 1.63 \\
\hline I & I. 47 & $\mathbf{I}$ & 1.55 \\
\hline I & $\mathrm{I} .62$ & . I & $I \cdot 71$ \\
\hline I & I. 54 & I & I. 64 \\
\hline I & .85 & I & $2 \cdot 31$ \\
\hline 1 & 2.46 & I & I. 55 \\
\hline I & 2.54 & & \\
\hline I & I.67. & & \\
\hline I & 1.03 & & \\
\hline
\end{tabular}

Each shareholder represented in the above measurements paid the same amount of money, but they were far from receiving the same quantity of water, under canal No. I the most generous box delivering nearly four times the amount of the one having the least discharge. Under canal No. 2 the fortunate irrigator received nearly three times as much water as the irrigator who received the least for his money.

The amount of money paid for water each year by irrigators is so large that it seems surprising that they have not paid more attention to the ac- 


\section{IRRIGATION INSTITUTIONS}

curacy with which it is measured. In transactions involving any other kind of property, care is taken to see that it is accurately measured; but, although water costs more than any other commodity used by the irrigator, it is bought and paid for without either buyer or seller knowing how much is delivered.

The need of greater accuracy in water measurement has led to the passage of a law in Utah requiring the State engineer to give information and advice about the placing of measuring devices. ${ }^{1}$ The State engineers of Colorado and Wyoming are required to advise irrigators in respect to the measurement of water, and a recent Colorado statute $^{2}$ also provides for the use of registers

1 Revised Statutes of Utah, 1898.

1282. Unit of Measurement. The standard unit of measurement for flowing water shall be the continuous flow of one cubic foot per second of time and shall be known as the second-foot.

1283. Id. Acre-foot. The volume of water required to cover one acre to the depth of one foot shall be known as the acre-foot and is equivalent to forty-three thousand five hundred and sixty cubic feet.

2457. To give information as to measurements of water. The State engineer shall, free of charge, give any information desired by any person as to the proper method of measuring water or of constructing an apparatus for such measurement upon proper application being made; and shall give special instructions to all water masters as to measurements of water, so as to secure a just distribution of the same.

2 Session Laws of Colorado, 1897. An Act to provide for and to regulate the exchange of water between reservoirs and ditches and the public streams.

Sec. 2. Any person or company transferring water from one 
which will keep a continuous record of the quantity of water delivered. (Plate I.)

The diagram (Plate II.) was taken from one of these registers. The flow delivered was supposed to be a constant one. Had this been true, the heavy line across the register sheet would have been straight. The diagram shows how far it varied from this.

The introduction of registers and greater accuracy in the construction of measuring boxes is one of the developments of the near future. Their installation will do much to reform water contracts, prevent the awarding of excessive amounts of water in decrees, promote economy and efficiency in use, and extend the reclaimed area.

public stream to another shall be required to construct and maintain under the direction of the State engineer measuring flumes or weirs and self-registering devices at the point where the water leaves its natural watershed and is turned into another, and also at the point where it is finally diverted for use from the public stream.

Sec. 4. When the rights of others are not injured thereby, it shall be lawful for the owner of a reservoir to deliver stored water into a ditch entitled to water or into the public stream to supply appropriations from said stream, and take in exchange therefor from the public stream higher up an equal amount of water, less a reasonable deduction for loss, if any there be, to be determined by the State engineer. Provided, that the person or company desiring such exchange shall be required to construct and maintain under the direction of the State engineer measuring flumes or weirs and self-registering devices at the point where the water is turned into the stream or ditch taking the same or as near such point as is practicable. 
IRRIGATION INSTITUTIONS

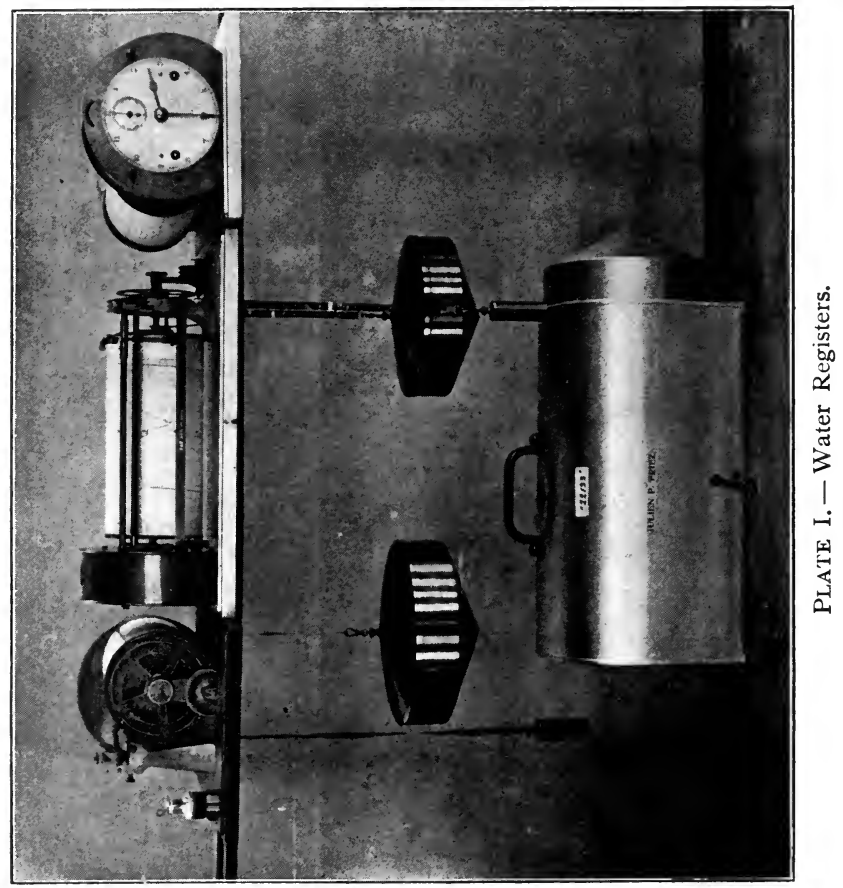




\section{MEASUREMENT OF WATER}

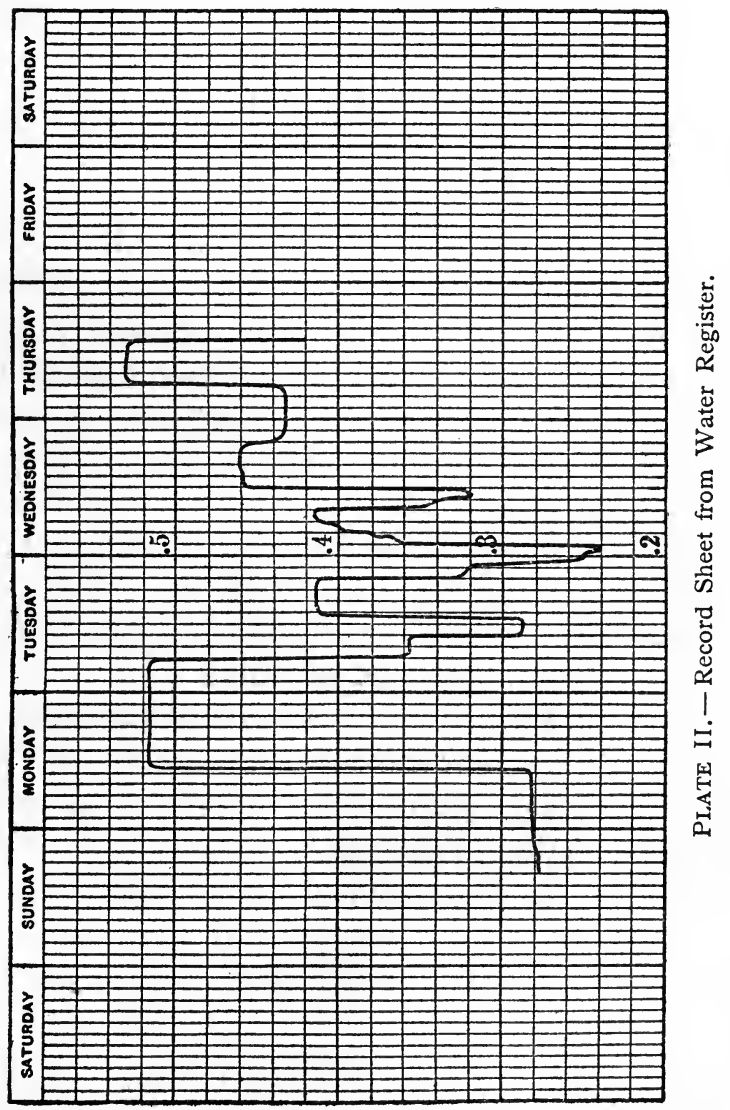




\section{CHAPTER VII}

\section{The Duty of Water}

THE duty of water in irrigation is the area of crop which can be matured with a given volume. Every one who has to do with irrigation needs a knowledge of the conditions which control this. Without this knowledge, neither the party who furnishes water nor the irrigator who uses knows how much will be needed, when it will be needed, or how it should be delivered to secure the best results. An approximate knowledge of the duty of water is as necessary in the distribution of water in irrigation as a unit of value in finance and trade. In the absence of such standard, it has often happened that serious mistakes have been made in fixing the dimensions of canals, usually in the direction of making them too small. Water contracts have been framed which do not conform to irrigators' necessities, and fail to secure either the economic distribution or best results from the water-supply.

The duty of water varies greatly and must of necessity do so. It depends in part on the economy and skill or negligence and waste which governs its distribution. It varies with the crop; oats requires more water than corn; alfalfa, more than 
potatoes; cultivated crops, as a rule, require less than uncultivated crops. Not only do different crops require different amounts of water, but they require it at different seasons of the year. During the first part of the season streams in the northern part of the arid region have an abundance of water, and crops which can be matured then rarely suffer from drouth. On the other hand, crops which require late irrigation must be watered when the supply is scarce and valuable. The time of irrigation has as much to do with the area which can be irrigated by direct diversion from a river as the amount required for different crops. For this reason, nearly all streams will irrigate more acres of small grain than of potatoes, because water is used when the supply is abundant.

In determining the duty of water, it is manifest that if water is applied sparingly it will cover a larger area, and if applied freely, fewer acres can be served. The limit of profitable economy is to use the least quantity of water necessary to secure the best yield. In the West there are many reasons for endeavoring to reach this limit, if not to go somewhat beyond it. Under the highest duty which can ever be secured not more than Io per cent of the arid West can ever be reclaimed. A higher duty of water, which will increase the watered area, will, therefore, add to the value of the water-supply and to investments in irrigation works, and render large areas of land productive which are now arid and unused. 
The duty of water is variously stated. When the flow of a stream is not stored, and the water must be used as it comes down from the snows, duty is properly expressed in a unit of flowing water, either the inch or the cubic foot per second. In the earlier discussions of the duty of water, the influence of the stored water was disregarded, and as a result the statements are nearly always made in terms of continuous flow. It was assumed that an inch or cubic foot per second of water flowing continuously was required for the irrigation of a unit area of land and the total area that the stream would serve was determined by dividing its discharge by this assumed duty; but to express the total volume of water used in irrigating an acre of land in any unit of flowing water it is necessary to give not only the rate of delivery, but the length of time this continues, or to do what amounts to the same thing, state it in a unit of quantity such as the acre-foot. This practice has recently been adopted, but it is usual to give the number of acre-feet of water used on an acre of ground. This is in reality the reciprocal of the duty, but is a more convenient form than to give the fraction of an acre which is watered with one acre-foot. It is also equivalent to a statement of the depth of water used on the land, and can thus be easily comprehended by all.

The use of the inch and the cubic foot per second still continues, however, even when it is desired to state the entire quantity of water re- 
ceived by crops during the season. In such cases it is necessary to know the length of time water

Diacram Showine Duration of inaication Period on Main Canals includeo in finveticatione.

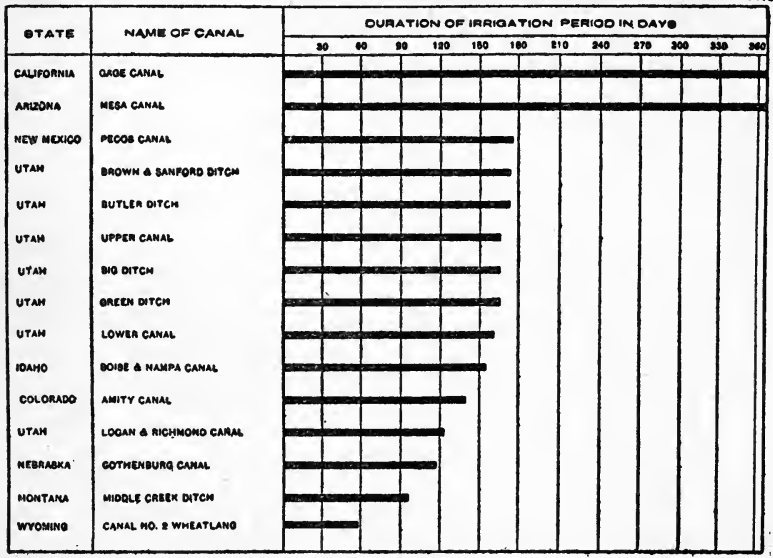

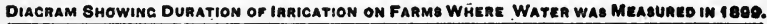

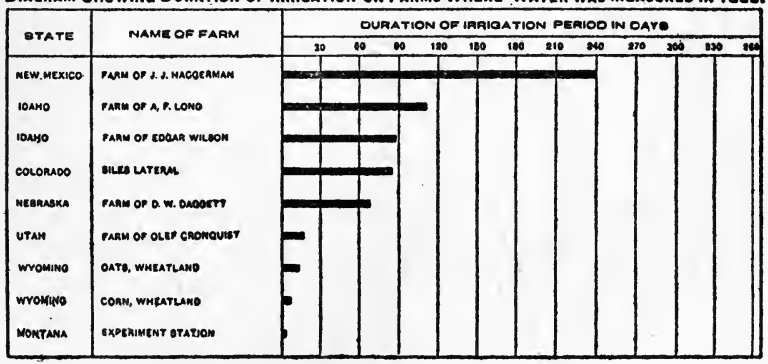

Diagrams Showing Lengtij of Irrigation SEason.

FIG. 2.

is used and to include in the statement so many details that it is confusing. The common practice in making comparison is either to disregard the 


\section{IRRIGATION INSTITUTIONS}

time element or to make an arbitrary assumption as to the length of season. Neither form of statement is satisfactory. The accompanying diagram (Fig. 2) shows the variations in the length of the irrigating season in different parts of the West.

In Montana the irrigation period is less than one hundred days and in Southern California it is between two hundred and three hundred days. Manifestly, a duty based on the inch of water for the irrigation period in these two sections involves the use of entirely different quantities on a single acre, the irrigator in California who purchases an inch receiving more than twice as much water as the irrigator of Montana.

In determining the area which can be irrigated by a given quantity of water regardless of the rate of its delivery, the acre-foot is the most convenient and definite unit of quantity. Where it is taken as the standard, all arbitrary assumptions involved in the use of either the inch or cubic foot per second are avoided. It is equally accurate whether the supply comes from streams, wells, or reservoirs, whether the use is continuous or intermittent, and whether it ends in two months or extends throughout the entire twelve. It has, therefore, been employed wherever possible in the discussion which follows. Those who wish to convert quantities expressed in acre-feet into equivalent values in inches or cubic feet per second need only to remember that a cubic foot per second flowing for twentyfour hours equals approximately 2 acre-feet, and 
that the miner's or statute inch flowing for a like period equals between .04 and .05 acre-foot, depending on the form of inch employed.

In the mining States the inch is the unit most frequently employed. In California the common form of stating the duty of water is the area which an inch will irrigate. In that State the ruling duty is five acres to an inch, but in some instances it irrigates ten acres. In a majority of the Rocky Mountain States a duty of one inch to the acre was the ruling standard at the outset, but an inch to three acres is now more nearly in accord with custom. A series of measurements of the quantity of water used, made by the late Colonel E. S. Nettleton, one of the leading irrigation engineers of Colorado, made fifty-four acres the duty of one cubic foot per second, and this became the ruling standard in the earlier water-right contracts of Colorado and adjacent States. This duty was based on measurements made on land which had been irrigated only a short time and where a large amount of water was required to saturate the subsoil. It is now much below the actual practice of irrigators.

Much attention is now being paid to this subject. The Agricultural Experiment Stations of the West are doing valuable work both in measuring the amount of water used and in giving to farmers instruction in better methods of application to crops. In the reports of the Irrigation Investigations of the Office of Experiment Stations, United States 
Department of Agriculture, are gathered together the results of observations made in all parts of the arid region by a large number of engineers, farmers, and scientists. The data gathered show wide variation in individual cases, the water used on farms varying from 15 acre-feet to an acre, to less than I acre-foot to the acre, but a careful study of the surrounding conditions in every case serves to disclose the reasons. While they show the necessity for care in making generalizations, there is every reason to believe that they will result in two important gains to irrigation practice. One will be the establishment of an approximate standard for the duty of water when measured at the heads of canals. The other is the raising of that standard by showing the causes of waste and loss. The extent of the losses in distribution, for example, gives room for confidence that the average duty of water in the West can in time be made nearly double what it is now without any sacrifice in the productive capacity of the areas irrigated. It must be remembered that this applies only to the average result. There are sections of the West, notably Southern California, where water is probably used with more economy and skill than in any other part of the world; but the methods of Southern California can be widely adopted elsewhere, and the fact that the duty there is nearly double that of other localities having the same climatic conditions gives added reason for belief in a general gain elsewhere. 


\section{THE DUTY OF WATER}

The duty of water as measured at the heads of canals is the standard which must be used for the division of water from streams. The average of a large number of measurements made by the Irrigation Investigations of the United States Department of Agriculture during the past three years was 4.45 acre-feet for each acre of land irrigated. Measurements made at the margin of fields showed an average of 2.37 acre-feet for each acre irrigated, or but little more than one-half of the water turned into the canals.

\section{Losses from Seepage and Evaporation}

The variation in the water lost from different canals and in different sections of the same canal is so great that few generalizations can be made. Each canal needs to be measured in order that its owners may know the need of improvement and what they must do to make this most effective. The loss from seepage and evaporation, as shown by a large number of measurements made by the Irrigation Investigations of the United States Department of Agriculture, was 2.47 per cent per mile in I900, and 1.45 per cent per mile in I9OI. Grouping these measurements together on the basis of the volume of water carried at the time of the measurement showed that the losses in small ditches are far greater than in large canals, as is illustrated by the following table:- 


\section{IRRIGATION INSTITUTIONS}

\section{Water lost by Canals}

Loss per mile, per cent

Canals carrying roo cubic feet per second or more $\quad . \quad$. .98 Canals carrying between 50 and roo cubic feet per second 2.67 Canals carrying between 25 and 50 cubic feet per second 5.22 Canals carrying less than 25 cubic feet per second . 7.48

Indian experience shows that losses in canals of from 30 to 40 per cent are not uncommon. A loss of 50 per cent in distribution is in accord with many of the measurements made elsewhere. In the irrigation of wheat under the Jamda Canal in Bombay, 5.6 acre-feet was received at the headgate for every acre of land cultivated under the canal, but measurements made at the margins of fields showed in two cases 2.I acre-feet, and I.4 acre-feet, respectively, for the acres irrigated. Extensive experiments on the Hathmati Canal in the same country showed losses from seepage and evaporation of fully 50 per cent. The losses from the new canals in the West ought to be equal to or greater than those of older irrigated countries, both because the canals are new and the banks unsettled, and because little care has been taken to secure economy in the delivery of water.

The term "seepage," in its broader sense, includes the water percolating through the soil from all sources, but in its narrower sense it is restricted to the water which escapes from ditches. The losses from the latter cause are probably greater in this country than in the older ditches of Europe 
because the prevailing practice in the West is to build a bank on the lower side of the canal only. This produces stagnant lakes and pools on the upper side wherever the canal crosses ravines or where the land on the upper side is so low that the water overflows the top of the excavation when the canal is filled. This is a prevailing mode wherever canals are built along slopes. In addition, much water is lost because care has not been taken in securing a perfect union between the embankment on the lower side of the canal and the original surface on which it rests. In order to secure this, it is necessary to have all of the growth and rubbish removed, and the original surface thoroughly ploughed, but in many canals precautions of this character have been wholly disregarded.

Where ditches are cemented, as in Southern California, or where the water contains a cementing material, as is the case in Arizona and some of the streams east of the Rocky Mountains, the loss in the main canals is comparatively small, but in much of the West the conditions are quite different. Instead of impervious channels, water is conveyed in open ditches over porous formations of loose earth and gravel. These formations act like a sieve when water is turned on them.

In one of the cemented canals of California water is transported 28 miles with a total loss from evaporation of only one per cent. Professor Fortier, of the Montana Agricultural College, has 


\section{IRRIGATION INSTITUTIONS}

determined by measurement that while the loss from both seepage and evaporation on one canal amounted to about $\frac{1}{3}$ of the total flow, the quantity evaporated was only $\frac{1}{75}$ of the loss by seepage. So long as owners believe that losses are due to evaporation, they will be content to let things alone because they cannot be regulated. Losses from seepage, can, however, be prevented, and as water becomes more valuable, this prevention will pay.

One of the causes of excessive loss is too great velocity, which prevents the deposit of silt upon either sides or bottoms of canals. The porous material over which the water runs is continuously swept clean and in a condition to lose the largest volume of water. Experiments have shown that one of the most effective ways of lessening these losses is by the silting up the bed with fine material. It is also shown that in ordinary soils a velocity of from $2 \frac{1}{2}$ to 3 feet per second is the one to be sought for.

Another means of lessening losses by seepage has been referred to. This is rotation in use. To bring this about will require time, as it will involve the reforming of many contracts between irrigators and ditch companies, which provide for the delivery of water in inches or cubic feet per second and make no provision for intermittent use. Many of the irrigation laws also restrict appropriator's rights to a continuous flow.

The principal losses from evaporation occur in 
laterals and in spreading water over fields. In passing through small lateral ditches water becomes heated, and when turned over the sun-baked fields it is rapidly dissipated in the surrounding air. Practical irrigators understand this. They know that a given volume of water will irrigate more acres at night than in the daytime. It is not an uncommon phenomenon to see the flooded area actually recede during the middle of the day, although a large volume of water is still running on it. The increased losses from evaporation more than absorb all the water carried in the laterals.

Losses from evaporation have, however, an important relation to the value of reservoirs. Measurements made at Phoenix, Arizona, show average losses for three years of $77 \frac{1}{2}$ inches. The loss at Mesa, Arizona, in 1900, from May 2 to November I2, was 47 inches. At Reno, Nevada, from May to October, 42 inches. At Wheatland, Wyoming, a series of measurements was made for the purpose of comparing the losses from tanks on land, like those reported above, with those from a similar tank floating in water, the latter presenting more nearly the conditions found in a reservoir. The loss from the land tank was 22 per cent greater than that from the other, showing that the losses given above are greater than would take place from the surface of a reservoir. The annual losses to be expected from reservoirs vary in different parts of the arid region from 4 to $6 \frac{1}{2}$ feet.

There are several factors which have tended to 
lower the duty of water in the West. One is the granting of rights to more water than was needed. The holder of such a right tries to divert all the water allowed in order to retain the privilege, often doing this to his own injury and that of his neighbors. Where charges for water are based on the acres irrigated, it always leads to wasteful use, the purchaser believing that the more water he applies to his land the more he gets for his money. In order to prevent abuses of this character, the legislature of Idaho, in I899, passed a law requiring all charges for water to be "based upon the quantity delivered to consumers, and not in any case to depend upon the acres irrigated."

Many water-right contracts assume a duty of water, and give the irrigator no rebate or reduction where he uses a less amount. Many require the irrigator to pay for the maximum volume used at any one time, instead of paying for the average volume delivered during the season. The irrigator, therefore, has to contract for what he will need during the heated term. Where rotation is not permitted he also has to procure water enough to flow over the land quickly. Men who realize that their charges for water go on whether their ditches are full or empty, are tempted to keep them full all the time and waste what they do not use.

Water-right contracts which provide for a continuous flow and charge for it incite farmers to waste water. They use it when they do not need 


\section{THE DUTY OF WATER}

it because they have to pay for it. The following extract from a water-right notice illustrates the objectionable feature of these contracts :-

To the Patrons of the Canal :

Water will be furnished for the irrigation season of 1899 at the rate of $\$ 225$ per cubic foot per second, continuous flow for the season, or, upon applicant waiving the right to demand water by quantity, at the rate of $\$ 1.50$ per acre, one-half of the amount to be due and payable on or before July I $_{5}$, and the balance to be due and payable on or before November I, 1899. No application will be received the amount of which is less than $\$ 5$, except for town lots. . . .

Where water is delivered by the cubic foot per second, the flow shall be a continuous flow as far as possible, and the amount contracted for will be the maximum amount that will be delivered at any one time. The maximum amount of water to be delivered by the acre at any one time will be at the rate of one cubic foot per second for fifty acres (or one miner's inch per acre), and the total maximum quantity allowed at \$1.50 per acre will be sufficient to put 2 feet in depth on land irrigated (equivalent to a continuous flow of one-half miner's inch per acre for Ior days). Any water used above said 2 acre-feet will be charged for at proportional rate.

Under this contract, if the farmer purchases water by the cubic foot per second, he has to pay for the greatest volume he uses at any one time, even if this larger use does not extend over more than a few hours. He has to pay at an emergency rate for periods when he does not use water at all. He has to buy enough water to give him an irrigation head, otherwise he wastes time in irrigation, or waters his crops so slightly that it is like a drizzling rainfall which, no matter how long it 
continues, never properly wets the soil. While this contract is called a delivery by volume, it is not so in fact. The irrigator does not pay for what he gets, nor is he rewarded by any saving he may make.

Mr. D. W. Ross, State engineer of Idaho, has made for the Department of Agriculture $^{1}$ a series of measurements of the quantity of water used by irrigators under contracts of this character, which shows that the skilful operator paid three times as much for the water he used as the wasteful one.

The following table summarizes some of $\mathrm{Mr}$. Ross's measurements : -

Cost of Water to Different IRRIgators Under the SAME Ditch

\begin{tabular}{l|r|r|r|r|r|r}
\hline User & $\begin{array}{l}\text { Volume } \\
\text { contract- } \\
\text { ed for }\end{array}$ & Price paid & Area & $\begin{array}{r}\text { Amount } \\
\text { paid per } \\
\text { acre }\end{array}$ & Water used & $\begin{array}{r}\text { Amount } \\
\text { paid per } \\
\text { Acre- } \\
\text { foot }\end{array}$ \\
\hline & $\begin{array}{l}\text { Cu. ft. } \\
\text { per sec. }\end{array}$ & & Acres & & Acre-feet & \\
No. I Lateral & 13.02 & $\$ 976.50$ & 790 & $\$ 1.23$ & $3,997.02$ & $\$ .24$ \\
No. 2 & 2.00 & 150.00 & 105 & 1.43 & 252.40 & .59 \\
No. 3 & 1.20 & 90.00 & 74 & 1.35 & 109.21 & .82 \\
\hline
\end{tabular}

While these three irrigators all obtained water under the same contract, and all at the same rate for a cubic foot per second continuous flow, yet the rate paid per acre-foot by the third was nearly four times that paid by the first. Mr. Ross's studies

${ }^{1}$ Bulletin 86, Office of Experiment Stations, United States Department of Agriculture. 


\section{THE DUTY OF WATER}

showed that one irrigator received only 43 per cent of the water allowed him under his contract. If he had wasted what he did not need, his water would have cost him at the rate of 20 cents an acre-foot. By using economy his water cost him 49.6 cents an acre-foot. All water-right agreements should promote economy. A charge for water by the acre-foot delivered rather than by the acres of land irrigated cannot fail to have a marked influence in increasing the duty of water. Another way to increase the duty of water would be to charge the farmer for what he uses each twentyfour hours. He will then realize how much it costs him each day; and if he knows that he is to pay only for the time his lateral is filled, care will be taken that water runs in it no longer than is necessary.

Many of the extravagant appropriations of water have had their origin in the practice of claimants stating the greatest quantity they had used in a single day, and receiving a decree allowing them this volume for the entire season. The Utah farmer, whose use of water is shown by Plate III, could have stated truthfully that he had used 4 cubic feet per second in irrigating his 60-acre farm, because he did use this volume for a few hours. The error in the decree was giving him a right to a continuous use of this quantity. Measurements in Arizona showed that an irrigator, in 1900, used Io cubic feet of water per second of time in watering 60 acres of grain, but he only 

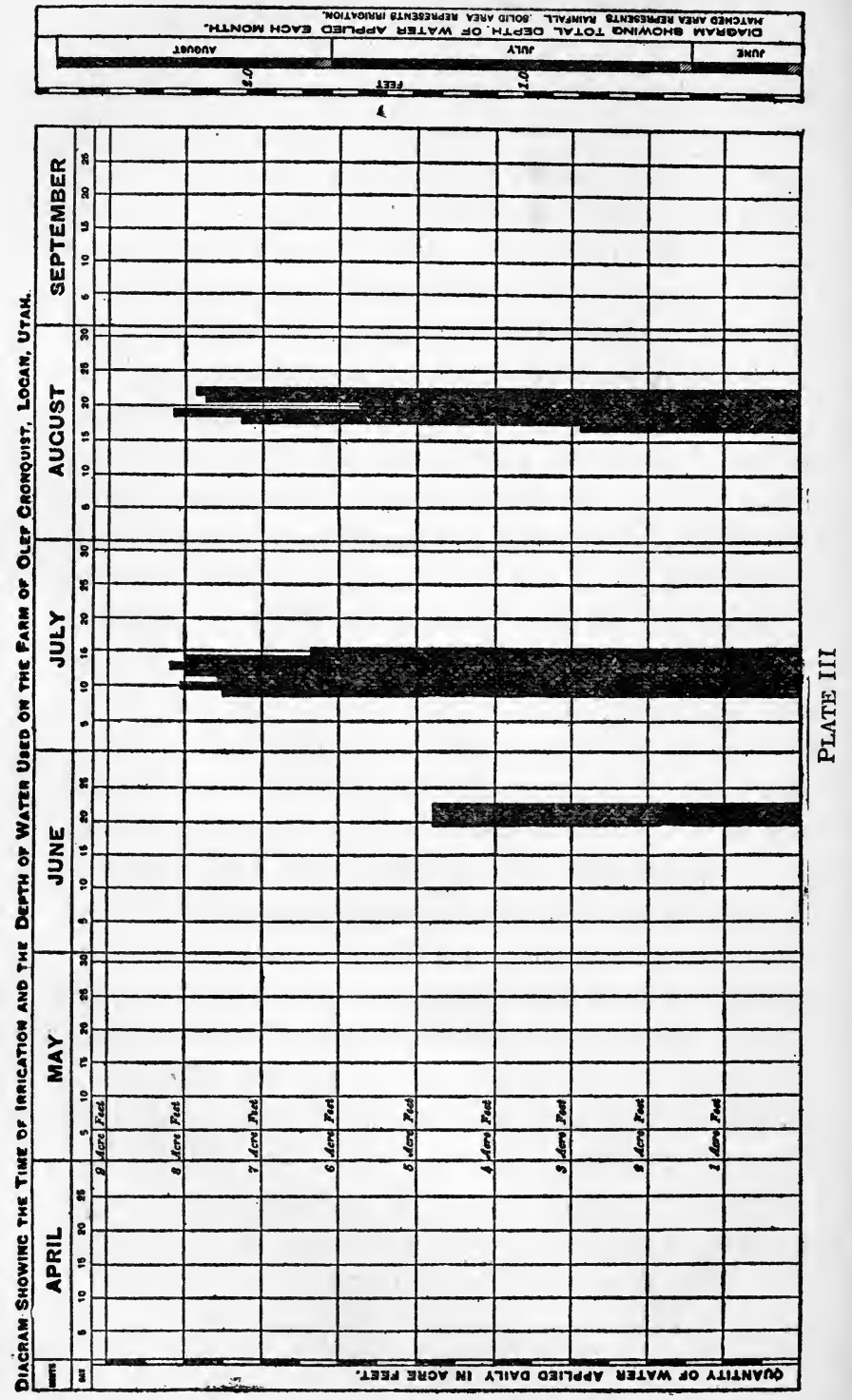
spent 6 days in its irrigation. To have allowed him this volume of water flowing continuously would extend the 6 days' actual use to a long period when water was not used at all.

\section{Rotation}

In many places where water contracts provide for the delivery of a continuous flow, in practice the use is entirely different. On the Gage Canal the irrigator of a IO-acre tract will purchase 2 inches of water, but he does not receive a constant flow of that volume. Instead, he is permitted to accumulate credits for the period in which water is not used, and at the end of 20 days of non-use he has credit of 40 inches of water, which he can take in 2 days at the rate of 20 inches a day, or, if he does not use water for 30 days, he accumulates a credit of 60 inches of water, which he can take in 2 days at the rate of 30 inches a day, or in 3 days at the rate of 20 inches a day. In this way he receives a sufficient flow of water to permit him to use it to advantage. On many canals rotation periods are arranged for, and the irrigator receives a large amount of water for a short time instead of a small volume of water continuously.

Some contracts recently made in Idaho provide for the delivery of water by the "24-hour inch," or fraction thereof. A scale of prices is adopted, and the irrigator can order and pay for whatever volume he needs and for the length of time which he needs it. 
The accumulation of credits, the sale of water by the "24-hour inch" or a similar unit, or by the acre-foot, all necessitate the arrangement of a system of rotation in use.

The owner of a large farm who purchases a sufficient quantity of water to provide a serviceable irrigation head can practise rotation in the irrigation of his own fields; but the irrigator of a small tract of land does not have this advantage, and where he is compelled by his contract to pay for the largest quantity he uses at any one time, he has to suffer. The practical advantages of a serviceable irrigation head in the pouring of water over the heated earth are so great that the adoption of some standard of measurement which will favor rotation should receive the attention of all interested in irrigation development. The stockholders in canals, the public, which hopes to secure the reclamation of the largest area, as well as the farmer who pays for the water, all have an interest in this matter.

The adoption of such a system would not only lead to better methods on the part of the farmers, but greatly diminish the time required to distribute water over the fields. A more important advantage is that it is equitable and just. Under such a contract the irrigator pays only for what he gets. $\mathrm{He}$ is punished in purse when he wastes water, and is rewarded for his economy when he irrigates with care. The effort to reduce the size of water bills leads to a better preparation of the fields and a 
better cultivation of the soil. The system of rotation which it involves, and the arrangement for the accurate measurement of water which it presupposes, both tend to the lessening of controversies and the strengthening of habits of system and order. The canal as well as the irrigator is benefited, because the economy of water permits the irrigation of additional land and an increase in the number of canal patrons. It also tends to lessen the losses from seepage and evaporation by lessening the miles of ditches and laterals which are kept constantly saturated.

A canal which supplies one hundred farms will have to furnish them the water they need whether they receive a small flow continuously or a larger volume as they need it. Rotation on large canals permits them to be divided into sections, and the watering of the land under one section at a time. A canal thirty miles long can be divided into three sections of ten miles each, and all loss from seepage and evaporation on the lower twenty miles can be saved while the irrigators of the upper section are being supplied. When the lower section is reached, water can be rushed through with less loss because the canal is full throughout its length and is not depleted by laterals along the route. The greatest saving in rotation, however, is made in the laterals. The most wasteful system of distribution is to permit water to slowly dribble through these laterals all the time. The manager of a canal, who can induce irrigators to take water by turns, 


\section{IRRIGATION INSTITUTIONS}

does more toward raising the duty of water than can be done by any other single reform. The use of a unit which lends itself to rotation does much toward securing this result. It also tends toward a rotation in the division of rivers between canals. Where streams are low and all the canals cannot be filled, there is great waste in keeping all of them partly filled. The loss from evaporation is practically the same whether the canals are filled or nearly empty. It is much better to run part of the canals to their full capacity for a few days and then turn the entire supply into others and thereby reduce the waste in transit.

The losses from seepage and evaporation amount to nearly 30 per cent of the total supply, and if one-half of this loss can be saved, it will result in a material addition to the income of many irrigation works.

The provisions of water-right contracts show a wide variation in the views held of the duty of water. The quantity agreed to be furnished in a large number examined varied from one acre-foot to the acre to 7.93 acre-feet of water per acre.

A proper understanding of the duty of water renders it necessary not only to determine the total volume used, but the amount required in the different weeks or months of the irrigation period. Canals should be planned to meet emergency requirements; they should be large enough to furnish the greatest volume required at any one time. It will do no good to flood fields in Septem- 


\section{THE DUTY OF WATER}

ber if the canal could not supply the water needed in July. The time when water is used in irrigation also determines how much land can be irrigated from the natural flow of streams. Stream gaugings give half the information needed to determine the area they will reclaim. They show how much water there is and when it can be had. This information must be supplemented by the time it is needed. Neither stream gaugings nor measurements of water used are complete in themselves. They must be taken together in forming rational plans for irrigation development.

On many streams a low duty of water does not indicate unskilful use. In the valley of Salt River, for example, irrigators have learned to provide against the season of shortage by pouring on the land all it will hold when the stream is high. In this way they store up in the subsoil a reserve for crops to grow upon when the stream is low and ditches are empty. Winter irrigation, while it lowers the apparent duty of water, is really a valuable means of saving a supply which would otherwise run to waste. The practice can only be commended as an imperfect substitute for the storage of water in reservoirs, because it does not produce the satisfactory results that are obtained when water is applied at the time when needed.

In his interesting discussion of the value of reservoirs as a means of regulating the discharge of Western rivers and increasing the use of their waters in irrigation, Captain Hiram M. Chittenden, 


\section{IRRIGATION INSTITUTIONS}

United States engineer, reached the conclusion that the storage of 25 per cent of the total run-off would enable the whole supply to be put to use, the other 75 per cent being taken directly from the stream during the irrigation period. In the same report, Hon. F. J. Mills, then State engineer of Idaho, estimated that one-half the total flow would need to be stored, while the writer's conclusion was that 40 per cent would need to be stored.

All of these were theoretical. Since then a comparison of the measurements made by the Office of Experiment Stations, United States Department of Agriculture, of the time when water is used in irrigation with the gaugings of the flow of streams made by the United States Geological Survey has coincided most nearly with the last-named percentage; but more facts are needed before any reliable estimate can be made regarding the average percentage required to be stored. Plate IV. shows graphically the results of one of these comparisons of the time when water is needed in irrigation and the time when it is furnished by a stream, and the amount of regulation which will be required to make the two coincide. The stream used in this case was Logan River, Utah. In three years, during which measurements have been made on this stream, the irrigation period began in June and ended in September, no water being required before or after these four months. The diagram was based on the use of water and the discharge of the river for 1900. In that year on the canals measured the 
Diagram Showtng Regutlation of Logan Rrvetr to Permtt Use of Entire Flow in Irrigation.

White areas remresent natural flow duming non-1rrigation period and black areas the natural fiow churing pertod of irrigation

Hatched areas represent timo when water stored during non-irrigation period would be used.

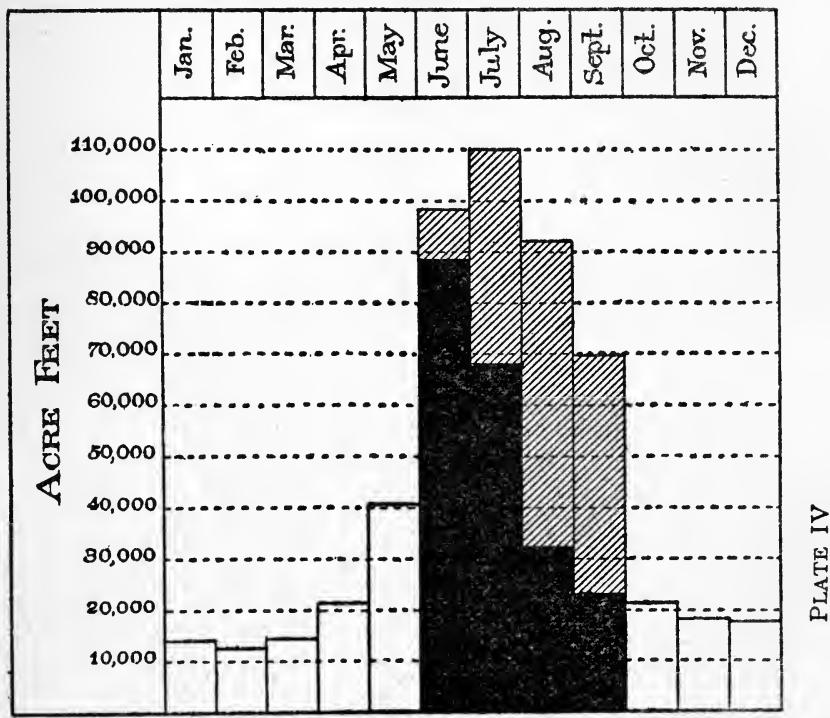

Diagram Showing when Water may be Stored and. Volume needed bo be Stored in onder to Dtilize Entire Flow of the Stneam.

\begin{tabular}{|c|c|c|c|c|c|c|c|}
\hline 14,081 & 12,551 & 14,204 & 21,957 & $\begin{array}{c}\text { ACRE FEET. } \\
\text { A0,582. }\end{array}$ & 20,783 & 18,089 & 17,401 \\
\hline
\end{tabular}

Diagram, Showing the Time when the Stored Waterwold be used. and Amount used each Month of Irrigation Season.

\begin{tabular}{|c|c|c|c|}
\hline 11,094 & 41,634 & $\begin{array}{c}\text { ACRE FEET } \\
59,700\end{array}$ & 46,480 \\
\hline JUNE & JULY & AUGUST & SEPTEMBER
\end{tabular}

ANNEAL ONSCHAPGE OF STREAM IN ACAE FEET $369,150$.
ACAE FEET AVAILABLE FOR IARIGATION BV DIRECT OIVEASION. $209,510=57$ PER CENT OF TOTAL DISCHARGE. 


\section{IRRIGATION INSTITUTIONS}

relative percentages of the water used in the different months were as follows :-

Per cent

June

26.8

July

29.7

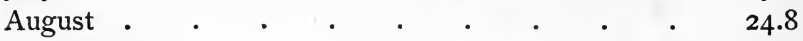

September

Total

The percentage of the total run-off of the stream for the different months was as follows :-

Per cent

January •

3.8

February

March

$3 \cdot 4$

April

May

June

July

August

September

October .

November

December

Total .

I I.O

5.6

23.6

18.3

8.6

6.1

5.0

4.8

$\frac{5 \cdot 9}{100.0}$

Without regulation by storage 43 per cent of the total flow runs off in the months when water is not needed, and only 57 per cent during the irrigation season. During the growing season the run-off of the stream is not in accordance with the needs of irrigators. There is more water in June than is required, and not enough in either August or September, so that regulation is needed to permit of the complete use of 
the 57 per cent which the stream carried during the four months when water is used. The storage of the water which ran off in the non-irrigation months, in such a way as to permit its being turned into the stream again when needed, would permit of the complete utilization of the 57 per cent by direct diversion. To utilize all the stored supply and furnish water to irrigators at the times when they would naturally use it, would require the following percentages of the total supply to be turned out of the reservoirs during each month of the irrigation period :-

Per cent

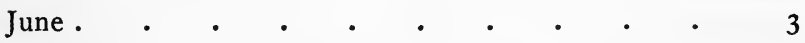

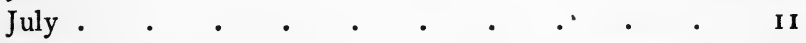

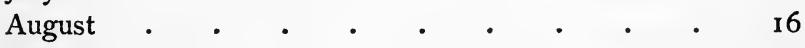

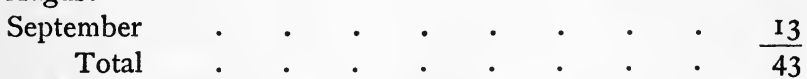

The diagrams give the quantities of water represented by these percentages.

The practice of pouring water on the land in order to fill the subsoil has resulted in making ponds and marshes of large areas, and is also bringing about the development of water by pumping. There are fifteen hundred pumping plants in the Santa Clara Valley alone, nearly all of which are drawing water out of the subsoil for application to the surface. Large pumping plants are being established in Salt River Valley for the same purpose.

The following conclusions regarding the duty of water in this country seem to be warranted:- 


\section{IRRIGATION INSTITUTIONS}

(I) That the duty of water in the older irrigated districts of the United States is as high as it is in the older districts of the world, showing that our practice is fully equal to theirs.

(2) Where low duty exists, it is due in part to excessive appropriations, and part to badly framed water-right contracts, and in part to losses from seepage in canals.

(3) The most effective measures for increasing the duty of water are to lessen losses by seepage, increase the water-supply by drainage, provide for rotation in use, and charge for the quantity received.

(4) That it is not unreasonable to expect that the present average duty of water will in time be doubled, and that there will be a large increase in the irrigated area from this cause alone. 


\section{CHAPTER VIII}

\section{IRRIGATION IN COLORADO}

IN a number of important particulars Colorado has been a leader in irrigation affairs. Although water is not so valuable as in California, more is being used. There are more miles of canals in Colorado than in any. other State; her mountains are the storehouse which fills rivers flowing into every surrounding State. To Colorado belongs the credit of having been the first State to enact a code of laws for the public administration of streams, and these laws have directly and indirectly influenced more people than those of any other commonwealth. It is appropriate, therefore, that they should be first described.

The first irrigators in Colorado were Mexicans. They established themselves in the southern part of the State, built small ditches, and cultivated small farms. The Mexican settlements have, however, grown slowly. Their colonies received few accessions from their own people, and their methods were not suited to Eastern farmers. The present irrigation system of Colorado had its birth in the northern part of the State along the South Platte and its tributaries. Along the branch of the overland trail which followed the South Platte 


\section{IRRIGATION INSTITUTIONS}

and the Poudre, ditches were built near stage stations and where settlers were assured of protection from Indians, as early as 1860 . The beginning of the colony enterprises at Greeley, Longmont, and Fort Collins came ten years later, and from that time to the present irrigation has been recognized as one of the State's important industries. The era of corporate canal building began in 1878 , and six years later the State engineer estimated that I,000,000 acres had been reclaimed. The first irrigation law was passed in 1861 , and governed the diversion of water from streams for twenty years. It gave the owners of land along streams the right to appropriate water for irrigation. The right of others than landowners to appropriate water was recognized in Article 16 , Section 5, of the State Constitution, adopted in 1876 , in which the water of every natural stream is dedicated to the use of the people of the State.

Under the law of I86I no record of appropriation was required. Sometimes notices were posted, and sometimes claims were recorded in the office of the county clerk, but there was no rule requiring this. County records were not required until I 881 , and State records not until I 887 . Under the law of I86I the principle of dividing water by rotation was legalized. The county judge was authorized to appoint three commissioners to apportion the water-supply among users on certain or alternate days, as in their judgment might be best. While this law was never formally repealed, 
the statutes of 1879 and I88I supplanted it, and court decisions have practically rendered it inoperative by giving rights to a continuous flow in the adjudication of appropriations. A recent decision of the lower courts has also denied water commissioners authority to require rotation in the use of water, although it would result in a great saving in distribution and a better protection of all rights except those of the earliest priority.

The Irrigation Acts of 1879 and I88I have a historic interest, because they were the first attempt in this country to assert public control over the division of streams used in irrigation. The credit of this innovation is due to the farmers of the northern colonies, chiefly those of Greeley and Longmont. This movement had its origin in the drouth of the summer of I874. The ditches above the Greeley Colony canal along the Cache la Poudre River had diverted the entire flow of the stream. There was great danger that the trees, small fruits, and lawns of the town would be ruined. Similar conditions also existed on a number of other tributaries of the South Platte. Expeditions from below destroyed the dams and head-gates of the irrigators above. The impossibility of agreeing among themselves over the division of the stream, and the uncertainty and anxiety of the irrigators under the lower ditches, created a sentiment in favor of public supervision. Neighborhood agreements were made, but these failed, or were not kept. Several conventions were held before an 


\section{IRRIGATION INSTITUTIONS}

agreement was reached regarding the principles of the bill finally adopted. In these discussions most of the farmers favored the establishment of rights by a special tribunal composed of practical men, who were personally familiar with the conditions and methods of irrigation. But this was abandoned because of the opposition of attorneys, who insisted that the determination of titles to streams was a judicial act which could only be performed by the courts. The committee which framed the bill also disagreed regarding the character of the rights to water which should be recognized. Some held that there should be no right to water except that of use, and that these rights should be attached to the lands reclaimed. Dr. J. L. Bond of Longmont supported this view with vigor and persistence, but was overruled by the irrigators from Greeley, who favored giving the rights to the ditchowners. There was also a disagreement regarding what should govern the amount of the right, - whether it should be the amount actually used or the amount which the ditch could carry. The law, as passed, makes diversion the sole test of an appropriation. Beneficial use is practically ignored. ${ }^{1}$

1 Said referee shall also examine all witnesses to his own satisfaction, touching any point involved in the matter in question, and shall ascertain as far as possible the date of the commencement of each ditch, canal, or reservoir, with the original size and carrying capacity thereof, the time of the commencement of each enlargement thereof, with the increased carrying capacity thereby occasioned, the length of time spent in such construction or en- 


\section{IRRIGATION IN COLORADO}

\section{The Adjudication of Water Titles}

Under the acts of $1879-188$ I any one interested may petition the district court for the adjudication of rights within his district. The statute provides for the taking of testimony by a commissioner or referee, for the rendering of a decree by the court, and for appeals therefrom to the supreme court at any time within four years afterward. Ample provision is made for protecting the interests of appropriators, but not the public interests, which are vitally affected by the transfer of streams from public to private control. Lack of consideration for the needs of future irrigators is the weakness of the Colorado system of establishing rights. The adjudication of water rights has a vital influence on the social and economic life of the communities affected, but in Colorado the only parties represented are those seeking control of the property. Neither the State engineer, the water superintendent, nor the water commissioner are given notice, nor is their advice asked regarding the prac-

largement, the diligence with which the work was prosecuted, the nature of the work as to difficulty of construction, and all such other facts as may tend to show compliance with the law in acquiring the priority of right claimed for said ditch, canal, or reservoir ; and upon all the facts so obtained shall be determined the relative priorities among the several ditches, canals, and reservoirs, the volume or amount of water lawfully appropriated by each, as well as by means of the construction, as by the enlargements thereof, and the time when each such several appropriations took effect. (Mills's Annotated Statutes, Sec. 2415.) 
tical questions on which the success of these decrees depends, and about which these officials are of all men the best informed. In many cases this litigation is the first experience of farmers with courts, and of attorneys and judges with irrigation. Practical and technical acquaintance with the subject has no assured influence, and often ignorance and inexperience have controlled. In the earlier adjudications no one knew how much water there was in a stream or how much was needed for an acre of land. When the adjudications were made, some ditches had been completed. A great many had been enlarged since their first construction, and often the owners did not know what the ditch would carry when it was first built, when the enlargement was made, or how much it had been changed. It was difficult for contestants to secure evidence. On a number of streams they did not seek it. The appropriators agreed among themselves as to the amount of water each one would claim, and that they would not dispute the claims of others, the court in such cases giving legal force and effect to an agreed division of public property, which was acquired not to use but to sell.

In the earlier adjudications the amounts of appropriations were based on the estimated capacities of ditches and canals. Sometimes the amount was fixed by the measurement of the ditch, and sometimes by what the appropriator claimed. With very rare exceptions it does not seem that the acreage of land which had actually 
been irrigated exercised any influence. The real issue was the amount of water diverted or proposed to be diverted. Proof on this point was largely given by men without engineering training and of limited experience, who, while honest, were very likely to be mistaken.

As the adjudications were held remote from the ditches and the land affected, and the judge or referee did not visit the lands and ditches to see for himself whether the situation was as it had been described, appropriators were encouraged to make extravagant claims. All of the conditions, therefore, contributed to favor the granting of rights to water in excess of the actual uses or necessities.

How far the decreed rights exceeded actual uses can be shown by a few examples. The Poudre Valley, on the whole, is the best example of irrigation in the Rocky Mountain region, and the excess appropriations decreed are rather below than above the average of the earlier adjudications. Nevertheless 2 I small ditches which irrigated 1000 acres of land were given rights to water amounting in the aggregate to 692 cubic feet per second, or one cubic foot of water per second to less than 2 acres of land. This would provide water enough to cover the land one foot deep each day of the season. One ditch which irrigated 620 acres of land 6 years after the decree was rendered was given 99.38 cubic feet per second, and another ditch which irrigated 160 


\section{IRRIGATION INSTITUTIONS}

acres was given 3 I cubic feet per second, or a cubic foot per second to each 5 acres of landmore than 20 times the volume which ' could be beneficially used. Altogether, the I04 appropriators from this stream hold adjudicated rights to 4,632 cubic feet of water per second. Let us now compare these rights with the water-supply. In August, 1894, the river's flow was 162 cubic feet per second, and in August, I893, I4I cubic feet per second.

In many instances the appropriations of water were largely in excess of the capacity of the ditches. The following examples, taken at random from the official measurements made by the State engineer in 1886 , - five years after the rights were decreed, - will illustrate this. Each of the four ditches was on a different stream, and their names and locations can be ascertained from the official records by those especially interested.

\begin{tabular}{c|c|c}
\hline Ditch & Amounts of water decreed & Measured capacity \\
\cline { 2 - 3 } I & Cu. ft. per sec. & Cu. ft. per sec. \\
2 & I22.00 & 50.30 \\
3 & 237.00 & 80.22 \\
4 & 99.00 & 78.00 \\
& 192.00 & 71.30 \\
\hline
\end{tabular}

Manifestly, ditches cannot divert more water than the stream carries, nor can the irrigators use more water than the ditches divert. Neverthe- 


\section{IRRIGATION IN COLORADO}

less, the volume of water which was granted in the earlier adjudications of Colorado was always greater than that which ran in the stream channels. The report of the State engineer for I89I gives the volume of water carried by the principal tributaries of the South Platte River and a table of the adjudicated rights to water from these tributaries. These permit of a direct comparison of the amount of water which was there to divert and the amount judicially declared to have been diverted.

Flow of Colorado Rivers and the Total Amount OF WATER DECREED TO HAVE BEEN APPROPRIATED THEREFROM.

\begin{tabular}{|c|c|c|c|c|}
\hline \multirow{2}{*}{ Name of stream } & \multicolumn{3}{|c|}{ Mean discharge } & \multirow{2}{*}{$\begin{array}{l}\text { Amount of } \\
\text { water } \\
\text { decreed }\end{array}$} \\
\hline & June & July & August & \\
\hline & $\begin{array}{l}\text { Cu. ft. per } \\
\text { sec. }\end{array}$ & $\begin{array}{l}\text { Cu. ft. per } \\
\text { sec. }\end{array}$ & $\begin{array}{l}\text { Cu. ft. per } \\
\text { sec. }\end{array}$ & $\begin{array}{l}\text { Cu. ft. per } \\
\text { sec. }\end{array}$ \\
\hline Cache la Poudre & 2942 & $72 \mathrm{r}$ & 265 & 4693 \\
\hline Big Thompson & 1362 & 349 & 137 & 2527 \\
\hline Clear Creek . & 968 & 378 & 137 & II 8 I \\
\hline St. Vrain . & 623 & 270 & 97 & 2883 \\
\hline \multicolumn{5}{|l|}{ Boulder and South } \\
\hline Boulder . . . & 996 & 348 & 123 & $474 \mathrm{I}$ \\
\hline Bear Creek . . & 379 & II 5 & $5 \mathrm{I}$ & 374 \\
\hline
\end{tabular}

Recent adjudications agree more closely with the facts. Although the law does not require it, proof of the land irrigated is nearly always submitted. Nevertheless, the granting of rights in excess of 


\section{IRRIGATION INSTITUTIONS}

the supply and of the volume used still continues.

Another defect in recent adjudications is the great diversity in the form of decrees and in the privileges conferred upon appropriators. There does not seem to be any reason for this if rights are based on beneficial use. The facts which control such use are so simple that there should be uniformity. It is certainly exceedingly desirable that one appropriation from the Arkansas or Platte should mean the same as every other appropriation, whether in the same or in other districts; but they do not.

The decrees in the different districts show a wide diversity in the nature of the rights conferred upon appropriators, and prevent any general statement regarding their character. Each referee or judge seems to have exercised his individual discretion or to have followed his personal opinions in determining what an appropriation of water should mean or in deciding what facts are necessary to establish it. This has given rise to some eccentricities and grotesque features in Colorado appropriations, which would not have existed if all rights had been established in accordance with some consistent policy. In the earlier decrees stress was laid upon the dimensions and carrying capacities of the ditches, and the amount of the appropriation was never less than the capacity of the ditch often several times that capacity. In recent decrees the amount of appropriations rests mainly upon the 
area of land irrigated. Where the acreage is the governing condition it would seem that the duty of water employed in computing the volume appropriated should be in approximate accord with waterright contracts, or with the average volume used in irrigation. This, however, is seldom the case.

Many of the decrees on the Arkansas River are based on an arbitrary duty of one cubic foot per second to 25 acres. This is water enough to cover land to a depth of 14 feet during the legal irrigation period of 180 days, or 28 feet for all the year. Many of the appropriators of water supply their customers with enough to cover the land to a depth of only 2 feet. In the adjudication of the Big Thompson River a referee determined the areas irrigated and the amounts of appropriations, and in his findings he gave the first appropriator one cubic foot of water per second for each 26 acres irrigated; the second appropriator one cubic foot per second for each I 2 acres irrigated; the third appropriator one cubic foot per second for each 3 acres irrigated - five cubic feet per second in all more than he claimed; the fourth appropriator received one cubic foot per second for each 34 acres irrigated, and the fifth, one cubic foot per second for each I 3 acres irrigated. Recent careful measurements show that the average actual use of water on this stream is only one cubic foot per second for each 187 acres irrigated.

An examination of recent decrees shows little improvement in this particular. One cubic foot 


\section{IRRIGATION INSTITUTIONS}

per second to 8 acres, one cubic foot per second to I 6 acres, one cubic foot per second to 50 acres, one cubic foot per second to 38 acres, one cubic foot per second to 44 acres, one cubic foot per second to 3 acres, are the awards of decrees rendered within the past ten years.

The State engineer's reports give the duty of one cubic foot of water per second as from 80 to I00 acres. Many water-right contracts provide for the delivery of one cubic foot per second for each 80 acres irrigated, and a number of recent ones for only 2 acre-feet of water to the acre. Hence these decrees give from three to fifty times the water actually needed, and are nearly as many times in excess of the actual average use in the districts where they were rendered.

It is hard to understand why in a matter of such importance competent engineering advice is not sought on this subject. It ought to be sufficiently established by experience that the statements of irrigators regarding the duty of water cannot be relied upon, even when they are made in good faith. In one instance a farmer claimed 2000 inches for 320 acres and was given 200 inches. $\mathrm{He}$ reported that he was receiving the entire amount claimed.

In many of the earlier decrees the rights to water granted were described as a continuous flow of a given number of cubic feet per second of time. The irrigation season was seldom defined; in many recent decisions it has been. In some 
recent decrees rotation in use is required. In one case the appropriator is declared to be entitled to water ten days out of thirty-two. While the water right always goes to the owner of the ditch, the decree sometimes names the ditch and sometimes its owner - sometimes both.

It was the belief of the framers of this law that a single adjudication would furnish a permanent basis for the division of water in each district, and put an end to water-right controversies. That it has not done so is due to the fact that the rights established have no relation to actual necessities. The water commissioner cannot follow the decree; to do so would require him in some cases to turn more water into ditches than they will carry. It would require him, in other cases, to give irrigators more water than they need, and at the same time charge him with the exceedingly delicate and troublesome responsibility of preventing waste. Every decree thus far rendered is no sooner put in operation than its disintegration begins. The holders of excess rights cast about for means to make money out of the surplus. Wherever they can extend their ditches, they do so; where they cannot, they sell or lease a part of the appropriation to later ditches. Every extension of an existing ditch, and every transfer to other ditches, increases the volume of water consumed by the early priorities, and lessens to that extent the amount available for later ones. In time this takes the water away from the farms which long have 
been irrigated, and supplies the water to lands recently reclaimed. Orchards which have come to maturity, and farms which have long been improved, find the rights which they had formerly exercised shifted to new areas of sage-brush and cactus plains. These evils have long been recognized by practical irrigators and by lawyers and judges.

In a brief before the State supreme court, Judge Elliott, an ex-justice of that court, thus forcibly describes them :-

Excess priority decrees are a crying evil in the State. From every quarter the demand for their correction is strong and loud. Such crying demand cannot be silenced by declaring that the meaning and effect of such decrees can never be inquired into, construed, or corrected after four years.

In many cases such decrees are so uncertain, so ambiguous, so inequitable, so unjust, and their continuance is such a hardship, that litigated cases will be continually pressed upon the attention of the courts until such controversies are heard and settled, and settled right. Litigation in a free country can never end while wrongs are unrighted.

Another distinguished irrigation authority, Mr. Platt Rogers of Denver, has added his testimony in the same direction:-

The decrees, in their entirety, are falsehoods and universally accepted as such. They furnish a fresh illustration of the truism that "a lie never ceases to do evil." If the construction heretofore placed upon them in some cases is to prevail, we have legalized a method of accomplishing the precise thing the Constitution intended to prevent, viz., speculation in water. 


\section{IRRIGATION IN COLORADO}

In I889 a commission was appointed to revise the water laws. On it were appointed a lawyer of high standing at the Denver bar, an ex-State engineer and one of the State's leading canal managers. They found little to change in the method of distributing water from the streams, but in speaking of the results of adjudications clearly summarized their defects :-

It resulted that the amount of water to which the several appropriators of the works of diversion were entitled was ascertained and determined in these decrees by the interested conjecture of those proprietors; that almost invariably the amount awarded largely exceeded - sometimes threefoldthe carrying capacity of the ditch, and that the whole volume of the stream was absolutely adjudged to the junior appropriators upon the upper parts of the stream, in proceedings to which the senior appropriators in the lower parts of the stream were not parties - where they had neither right nor opportunity to be heard. The decrees, therefore, instead of affording, as was intended, a just, true, and absolute measure of the rights of all appropriators for irrigation, are, in fact, false and misleading, even as to those who participated in the inquiry upon which they are founded, and absolutely void as to all others. ${ }^{1}$

Outside of two or three districts none of the Colorado decrees describe the land to be irrigated. The water commissioners cannot tell whether water is being applied on the lands where first used or exercise effective action in preventing waste.

The State engineer and water commissioners have difficulties enough in dividing the constantly

${ }^{1}$ Report of Commission appointed to revise Water Laws of Colorado, p. 7. 
varying flow of streams when the place where the water is to be used is fixed and unchangeable, but in Colorado their chief source of trouble is the attempt to make use of the extravagant rights granted in the early decrees, which leads to constant sales of surplus rights and to constant attempts to transfer rights from one piece of land to another. Speaking of this, the Hon. A. J. McCune, State engineer, in his last report said:

It appears to us that the most serious question connected with irrigation is the unstable condition of our water rights. In many instances, as the communities depending on irrigation grow older, complications seem to increase rather than decrease. . . Many of our troubles have arisen from carelessness in issuing decrees and by overappropriations, the present method being a kind of grab game without the necessary public supervision.

This situation deserves careful consideration, not only from irrigators in Colorado, but in the other States. It raises the question as to whether the evil of excess decrees is wholly due to lack of experience or is the result of a defective method of establishing rights. The latter is believed to be the truth. It is believed that if the determination of water rights was intrusted to a body of trained irrigation experts, who had a practical knowledge of the subject and who would familiarize themselves by personal investigation with the use of water on every stream where rights are to be established, the results would be far superior to anything which is possible under the present plan. 


\section{IRRIGATION IN COLORADO}

The present system requires judges to determine matters that ought to be settled by water commissioners. The errors are not of law but of facts, and judges ought not to be required to perform the duties of irrigators or hydraulic engineers.

If, however, the laws of Colorado require rights to be established in the court, these decrees should be preceded by a preliminary investigation made under the direction of the State engineer. If he measured the ditches, determined the acreage of land irrigated and the amount of the water-supply, and made an approximate estimate of the quantity of water required for an acre, the excess decrees of the past would be unnecessary if not impossible.

\section{Administration of Streams}

The State engineer and his assistants control the division of streams among irrigators. The office of State engineer was created in the act of I879, which divided the State into water districts based on drainage lines. In fixing the boundaries of districts, the aim was to have each one include enough territory to justify the appointment of a commissioner, and no more than one man could effectively supervise. The number of ditches rather than the square miles of land was the thing to be considered. It was necessary that there should be no more headgates than the commissioner could regulate in times of scarcity, and this made it necessary to divide some rivers into sections, and to make the tributaries independent districts. 
Each important drainage basin in Colorado is made a water division, and a division superintendent has general direction of the diversion of water within its boundaries. In each district the division of water is looked after by a water commissioner, who is subject to the orders of the division superintendent. The boundaries of districts are changed from time to time by the legislature. Being governed by drainage lines, they do not agree with either county lines or judicial districts. The law grouping these districts into divisions was passed in $\mathrm{I} 887$, in order to avoid a repetition of troubles which arose in the summer of i 886 over the division of water among the districts along the South Platte River. This river had been divided into three districts, which cut the stream into three sections. Each of these was independent of the others both in the adjudication of appropriations and in the division of water by commissioners. It followed that the district farthest up the stream had the best water-supply, and its commissioner refused to recognize the claim of the older appropriators in the districts below. As there was no law for the division of water between districts, the State engineer was confronted by as perplexing a question as the later problem of the division of water across State lines. The law which ended this complication made it the duty of the division superintendent to procure certified copies of each decree establishing rights to water in his division, and from these decrees prepare a list of priorities I 60 


\section{IRRIGATION IN COLORADO}

of all the ditches, canals, and reservoirs, retaining the dates of their original appropriations and giving them consecutive numbers in accordance with these dates and without regard to their priority numbers in the water district taken alone.

The adjustment of existing rights under this law and the renumbering of priorities in each division so as to make them consecutive was, in the older irrigated districts, a momentous undertaking because of the changes it wrought in the value of rights. Those injured contested the validity of the law and the justice of the superintendent's action. This was not, however, an objection to the measure. It only showed the ingenuity and persistence of those who sought to retain benefits conferred upon them by the imperfections of the earlier law.

At present Colorado is divided into six water divisions and seventy water districts. The administrative officers of this system are all appointed by the governor for terms of two years. The State engineer is the head of the system; the six division superintendents direct the work of water commissioners in the districts of their divisions, while the water commissioners are subordinate to both the water superintendents and the State engineer.

None of the irrigation officials interfere with the use of water until called upon by some appropriator whose rights are being interfered with. This is done by a written application to the water commissioner, or the division superintendent, asking for a protection of rights. The water commissioner 
has to act when he receives such a petition and becomes an arbiter who prevents many neighborhood feuds and greatly lessens the discord and anxiety of water users.

Whenever the water commissioner is called out, he has to report to the superintendent the time when he begins his work and the time when his duties cease. The superintendent can, however, call out water commissioners whenever he deems it necessary. In addition to the regular reports as to time of service, the water commissioner is also required to make reports concerning the general condition of irrigation within his district, these reports to include the following information:-

(a) The amount of water needed to supply all ditches and reservoirs in his district, meaning, of course, under each stream in the district.

(b) The amount of water coming into the district to supply such needs.

(c) Whether the water-supply is on the increase or decrease.

(d) What ditches or reservoirs are, at the time of the report, inadequately supplied.

(e) The probability concerning the supply prior to the next report.

$(f)$ Such other and further information as the superintendent of irrigation of that division may suggest.

In 1889 the law relating to water commissioners was modified, greatly extending their duties. The commissioner is invested with the powers of making arrest of any person violating his orders relative to the opening or closing of the head-gates and of 


\section{IRRIGATION IN COLORADO}

prosecuting offenders before the justice of the peace. $\mathrm{He}$ is also authorized to employ suitable assistants, and his duties are extended to exercising a guardianship over the streams of his district, keeping them clear of obstructions, etc., and he is made subject to fine for a failure to perform his duties.

In 1897 the duties of the water commissioners were still further extended to a supervision of exchanges of water from one public stream to another, and between reservoirs and canals. In order to facilitate the performance of these duties, those making such transfers are required to construct and maintain measuring flumes or weirs in connection with self-registering devices which will keep a continuous record of the water flowing through them. In this way the water commissioner can be kept informed of what is taking place when he is not present.

In I899 authority was conferred on appropriators to exchange or loan water for a limited time, and for making permanent changes in the point of diversion. The water commissioner is required to recognize these changes, and to enforce the agreements under which they are made. It will thus be seen that the water commissioner is the most important officer with whom the Colorado farmer comes in contact. The efficient discharge of the duties imposed upon him requires firmness, energy, hard work, and more than average judgment. He has to deal with a constantly fluctuat- 
ing water-supply; he has to determine whether or not water is being used with economy; he has even to exercise discretion as to how the relief of suffering appropriators can be best afforded. On his action, and in many instances on his tact and judgment, the peace and harmony of the neighborhood depends. He more than any other individual or official can promote economy in the use of water and extend the acreage of crops which are brought to maturity. All of the other steps under the Colorado irrigation code are simply preparatory to the work of the water commissioner. It is only when codes provide for the enforcement and protection of rights by some such official that water titles can be considered as having a stable and definite value.

Although the State engineer and division superintendents do not come so directly in contact with the farmer, there is equal need of their possessing the same kind of qualifications. To one or both are always referred the troublesome cases where the action of the water commissioner is contested. The duties of the State engineer are numerous. Besides having charge of State engineering work and acting as adviser in that capacity for the different departments, he is the head of the irrigation administration, to whom appeal may be made from commissioners and superintendents. He has supervising control over the public waters, makes measurements of the flow of the streams, collects data on irrigation works, canals, reservoirs, and under- 
ground water-supplies, as well as on the snow fall, and estimates the probable supply of water from that source. Designs and plans for dams in excess of ten feet in height are subject to his approval. He furnishes the commissioners and superintendents data and information for the proper and intelligent discharge of their duties; requires the owners to supply ditches with measuring devices, and superintends their construction, rates the flumes, and in addition collects statistics of crops and the water used in the different ditches.

The superintendent of a division has general control over the water commissioners in his division. He has to determine whether loans or exchanges of water will impair the rights of other appropriators or whether they shall be recognized, but his main duty is to regulate the flow of water into and from each district, so that priorities shall be protected in their respective order in the different districts throughout his entire division.

The commissioners report to him each week the names of ditches drawing water, and if the supply runs short, make a request for water; and when it occurs that ditches of a later date in the district next above are receiving water, the superintendent orders such ditches closed and the water sent down to the older appropriators below. In distributing water between districts, much must always depend upon the discretion of the superintendent as to what tributaries shall be called upon to supply the main stream, in order that the relief of those 


\section{IRRIGATION INSTITUTIONS}

having superior rights may be afforded with the least disturbance to other appropriators. In theory, the last appropriator should be the first to be cut off, but in practice it often happens that this appropriator is fifty or one hundred miles away, while another appropriator, inferior to the one seeking relief, is near at hand. To wait for water to come from turning off the last appropriator might cause the loss of crops, and in practice it is often the junior appropriator who can be first reached whose water-supply is curtailed.

The administration of irrigation laws in Colorado has been one in which the State can take just pride. The State engineer's office has been filled from the first by men conspicuous in their profession for honesty, tact, and ability. The water superintendents and commissioners have performed their arduous, and oftentimes thankless, tasks with justice and efficiency. Much of the preëminence which the State now enjoys is due to the ability and disinterestedness with which the water laws have been administered. It was a piece of rare good fortune, both for Colorado and the West, that the first administrative system was put in force under the direction of Colonel E. S. Nettleton, who won a national reputation as an irrigation engineer and administrator of irrigation works. It required all his tact and influence to bring about the acceptance of public control, and put an end to the jealousies of rival ditchowners and the fears of hostile communities. Those who live under the laws as 
they are administered to-day cannot realize the difficulties which beset those who blazed out the new trail.

The administrative features of the Colorado law have been largely copied in both Wyoming and Nebraska, and have worked equally well in those States. But both these States have surpassed Colorado in their method of establishing water titles, and in other features of their irrigation codes.

The water deeds, or water-right contracts, of most of the Colorado ditch companies tend to promote economy in the use of water. While this is done in the interest of the ditch company rather than to promote the general welfare, it nevertheless has the latter result. The definition of the irrigation period, contained in most of these contracts, is a sensible one, and it is an excellent thing to have the period defined. The land to be irrigated is described, and the water right is attached to the land - another excellent feature. The rights of farmers are limited to economical use. They are given no surplus water to rent or sell in times of scarcity. All these are good features, and should have been incorporated in the original appropriations. If the water of streams is public property, the public should show the same business ability in disposing of its property as those to whom its control is transferred. Colorado can learn something about the management of the water of streams by studying how canal companies dispose of the water which they appropriate. 
The county commissioners of the different counties in Colorado are given power to fix water rates where ditch companies charge an annual rental. The laws of Colorado also prohibit charging a bonus for the privilege of purchasing water from a canal company, and the requiring by those companies of advance payment of water rentals. Any one who has been furnished water and paid the rental therefor can compel the company furnishing it to continue to do so forever thereafter on tendering the rental charged.

These rental laws are not looked upon with favor by companies having large appropriations of water, hence most of the water-right contracts now being made fall under the second plan described in Chapter V. While nearly all of these contracts provide for the transfer of the ditch and its appropriations at some future date to the purchaser of the water rights, the stipulations concerning these are so indefinite that the farmers cannot compel the transfer; and there have been but few instances thus far where the management of these works has fallen into their hands. There is no question, however, that it would be a gain for all concerned if farmers could have the management of the works which supply their farms, and if all the ditch companies in Colorado could become cooperative enterprises. It is believed that this is what will ultimately happen, and when the owners of ditches cease to act as middlemen between the State and the farmer, the irrigation system of 


\section{IRRIGATION IN COLORADO}

Colorado will be relieved from its most serious menace.

Colorado leads all the arid States in the construction of reservoirs. In the two years ending December I, I900, I47 permits for the construction of these works were issued by the State engineer. The plans submitted include every type of storage work. Some are to regulate the flow of rivers by constructing dams in their channels. Others propose to fill natural basins situated in the midst of the land to be irrigated. Some of these reservoirs are remote from the lands to be irrigated. The stored water has to be turned into the natural channel and mingled with the natural flow of the stream, and be carried many miles from the place of storage to the place of use, and its delivery requires the regulation of numerous head-gates in order that it may be delivered to the canal owning the reservoir or purchasing the water it impounds. The increase in the number of storage works in Colorado has been accompanied by an equally interesting and not less important growth in laws and customs to govern the use of this stored water.

The ability to obtain a late water-supply through storage has also led to a change in the character of Colorado's agriculture which has amounted almost to a revolution. When irrigation began, wheat and native hay were the principal irrigated crops. They require water only during the early part of the season or during the time when streams 
carry the most water. These crops could be brought to maturity before the water-supply fell off, and there was little need of storing water for use during the later part of the season. All this was changed by the introduction of diversified farming and the growing of high-priced products. The irrigation of orchards requires the use of as much water in November as in May. Alfalfa, potatoes, and small fruits all require late irrigation.

These changes have added greatly to the returns from the cultivation of irrigated land and to its value, but they also make a greatly increased demand for a late water-supply. This cannot be provided from the natural flow of streams. When the snows of the mountains of Colorado disappear, the waters of its rivers shrink not slowly, but suddenly. The irrigator who quits work Saturday night with all the water he needs, often finds when he attempts to resume his labors on Monday that his ditch is empty. After July 15 the pioneer appropriators control the water of most streams. There is not enough left for the large late ditches to keep alive shade trees and orchards, much less to mature even their more valuable farm crops. Farmers have seen their crops ruined for the lack of water which ran to waste less than a fortnight before, and have set about to remedy this by holding back the surplus water-supply of the early part of the season by means of storage reservoirs.

Appropriations of water for storage purposes are inferior to those for direct irrigation. Recent deci- 
sions of the supreme court seem to make this an established principle of the Colorado irrigation system. In some respects this is a true economic policy, because it would be a waste of money to store water which could be used directly on the crops; but on the other hand the water would have a far greater value if it could be stored and used on high-priced crops which require late irrigation. Under the existing system, however, reservoirs must be filled and replenished when there is a surplus in the stream. They can only take water when it is not immediately needed by irrigators under ditches.

The growth of reservoir construction is making the establishment of priorities and the amounts of appropriations for these works but little inferior in importance to the original appropriations for ditches. They are established in the same manner, through decrees of the district court, and the priorities between reservoirs are recognized and enforced by the water commissioner exactly as he divides the natural flow of streams between ditches.

The beginning of reservoir construction was delayed somewhat by legal and economic obstacles. Many of the natural sites are so located that they cannot be made to serve the lands lying under the ditches which fill them. They are high enough to irrigate lands under other ditches, but without some agreement with the owners of low-lying lands the ditches which supply these lands with water 
could not be utilized. What was necessary was a system of exchanges of water, by which the upper ditch could throw the water stored in its reservoirs into the lower ditches and be permitted to take in lieu thereof an equivalent amount of water from the stream. A system of transfers of this kind has been worked out. At first it was based only on custom and neighborhood agreement, but later it was sanctioned by law and is an important contribution to irrigation legislation, not only in Colorado, but as an example in other States.

There are nearly fifty reservoirs in the valley of the Poudre River, and about an equal number in the valley of the Big Thompson. The greater part of the water they hold is used on the lands of others than their owners. Many of the early priorities on these rivers are along the lower part of the streams. The reservoirs are filled from ditches on the upper part. The owners of the reservoirs supply the ditches further down-stream with stored water, and in return therefor are given permission to use the natural flow. To carry out these exchanges, however, requires a more accurate measurement of water than prevailed when there was nothing to be done but divide the stream itself among the canals. The people who exchange stored water for water from the river see to it that they furnish no more than they get in return, and the holders of rights in the stream other than those concerned in these exchanges are also on the alert to see that they are not robbed by these transac- 


\section{IRRIGATION IN COLORADO}

tions. This renders it necessary that the water taken from the river and the water turned out of reservoirs and into ditches shall be accurately measured by some disinterested authority. In order to insure this, the law has made the water commissioner a sort of public gauger who superintends these transfers and keeps a public record of all exchanges.

Two important changes were made in the Colorado irrigation code in 1899 . One relates to the sale of appropriations of water by one ditch company to another and the transfer of the point of diversion from the stream. The other gives appropriators the right to loan water to others in times of scarcity.

\section{Sales of Appropriations}

Although the right to sell appropriations and transfer them from the ditches where first acquired to other ditches, and to transfer water from the land where first used to other places and other uses, has always been claimed, it has always been disputed and has been the cause of much litigation. This law promises to lessen these controversies by requiring that these transfers shall be made under a specific procedure. Heretofore they could be made without any legal formality. After they had been made it was always difficult to set them aside, and an attempt to do this imposed on other appropriators a constant and grievous expense in 
maintaining contests. Now these sales can only be made on the approval of the district court.

Some objection has been made because such transfers will involve a large outlay in presenting the matter to the court. But aside from this the measure is destined to work much good. It will lessen the opportunity to give speculative value to excess appropriations. If sales of appropriations are to be recognized at all, it should be only after careful investigation.

Arguments in favor of these transfers are that they will promote a more economical use of water through the consolidation of appropriations, that they will permit of the closing up of numerous small ditches, and the diversion of the water-supply in a few large canals. In other words, it is the trust argument applied to the control of rivers. If in these transfers the tracts of land from which the water is taken were described, and if it were applied to no greater acreage elsewhere but simply to better land or in a more saving manner, there would be no objection; but so far as the writer's observation has gone this is not the moving purpose of these sales. In every instance investigated the real purpose has been to make money out of excess appropriations. The parties who have acquired surplus rights are unable to use the water themselves, and seek to sell to some one who can. The primary object is not economy, although this sometimes results. The usual result is to take as much water away from one user as is supplied to another. 
The objection to sales of appropriations does not apply to the law which recognizes exchanges of water between reservoirs and ditches. Here there is an undoubted gain, both to public and private interests. It is a recognition of natural needs and gives the sanction of law to the most convenient and effective means of putting to the best use the ditches already built, and of storing the surplus water in the most convenient and economical manner.

\section{Loans of Appropriations}

Section $3^{1}$ of the act of 1899 has been the subject of discussion, of litigation, of praise, and of blame ever since its enactment. Opinions of men regarding both its purpose and its results seem to depend on whether they are benefited or injured by its operation. It is difficult for one to form a definite opinion regarding its merits from the statements of either writers or officials. The strongest commendation which has come under the writer's notice is that of ex-State

${ }^{1}$ Sec. 3. It shall be lawful, however, for the owners of ditches and water rights taking water from the same stream, to exchange with, and loan to, each other, for a limited time, the water to which each may be entitled, for the purpose of saving crops or of using the water in a more economical manner ; Provided, that the owner or owners making such loan or exchange, shall give notice in writing signed by all the owners participating in said loan or exchange, stating that such loan or exchange. has been made, and for what length of time the same shall continue, whereupon said water commissioner shall recognize the same in his distribution of water.

Approved April 6, 1899. (Session Laws, 1899, p. 236.) 


\section{IRRIGATION INSTITUTIONS}

engineer Greene, who says : “This growing custom of loaning water is not only a great step toward the solution of some of our irrigation problems, but is of value as an indication of the attitude of the people of the valley toward the solution of such questions. When the people under some ditches voluntarily deprive themselves of water to which under decrees they are entitled, for the purpose of having those waters applied to the saving of crops under other, perhaps rival, ditches, they give promise of a very high order of irrigation development. This voluntary loaning of water, which always involves some losses on the part of those making such loans, is a very forcible expression of the desire that not a man in the Arkansas Valley shall lose his crops for the lack of water."

Mr. Greene is one of the most careful and accomplished students of irrigation questions in this country, and his opinion is entitled to great weight. His commendation is confined to the Arkansas Valley, and what he says is doubtless true of some sections on that stream where the ditches are small or where the appropriations of water were acquired by farmers; but there are other sections on the Arkansas River and on other streams where a different condition of affairs exists, where appropriations of water do not belong to owners of the irrigated farms but to ditch companies, and where the farmers do not obtain their water-supply by appropriating it but by the purchase of a water deed or water contract from the appropriator. It 
is these companies and not farmers who are loaning their appropriations. Nor do they confine their loans to the water they would otherwise use. What they prefer to do and what they are attempting to do is to loan the water which they do not need, and by so doing put parties having late priorities in the place of the holders of earlier rights who would otherwise receive it.

In a recent lawsuit growing out of one of these transfers on the Arkansas River, before Judge Voorhees of the tenth judicial district, the following facts were admitted:

(I) That the Fort Lyons Canal Company, plaintiff, has appropriated 76r.8 cubic feet of water per second of time.

(2) That of the four defendants the Arkansas Valley Company had appropriated 70 cubic feet of water per second of time; the Twin Lakes Company had appropriated 756.28 cubic feet of water per second of time ; the Catlin Company had appropriated 248 cubic feet of water per second of time; the Laguna Canal Company had appropriated 155 cubic feet of water per second of time.

It will be seen that the aggregate of these five appropriations is I99I cubic feet per second, which is far more than the average flow of the river. None of these appropriators are farmers. All are companies which have appropriated water to sell to farmers, and in each case the contracts under which they sell it describe the land on which the water is to be used and give the farmers only the 
amount they need, so they have no surplus to loan. The loans objected to were not evidence of a neighborly feeling between farmers, because farmers had nothing to do with them. They were simply commercial transactions in water between four large corporations.

It was admitted that at the dates of loaning the water, the two companies which made the loans had no present need for the water, and that making these loans did not involve any sacrifice to the lenders. They did not promote economy nor good feeling. The farmers under the ditch which brought the suit to prevent the loan, would have used the water as savingly as those who received it.

The injunction sought was refused, the court upholding the law on the ground that a priority of right to the use of water in Colorado "is a property right with all the incidents of property to its decreed amount." In one of the divisions in Colorado the loaning privilege has been interpreted so liberally that there is reason to believe that actual sales of water have been made by the holders of the old appropriations. This practically nullifies the doctrine of priority. Under it, what A does not need belongs to $B$, and if $B$ does not need it, it belongs to $C$; but under these laws $A$ can let $\mathrm{D}$ have his appropriation and thus take it away from both $\mathrm{B}$ and $\mathrm{C}$. The knowledge that such loans can be made is leading to an extension of the irrigated territory under ditches which 
would have no water at all under a rigid enforcement of the doctrine of priority, so that crops are not only being " saved," but planted and matured on borrowed water. It has greatly augmented the value of early rights, aggravated the injustice of excess decrees, robbed irrigators who were justly entitled to water under the doctrine of priority, and shifted the location of the lands irrigated, rather than "saved" the crops of the irrigators. It is but just to say that this act has the qualified approval of the State irrigation authorities, and that, in the majority of districts, the water commissioners report that it has worked beneficially. Nevertheless, it seems to be a dangerous measure.

An irrigation district law was passed in I90I. It provides for the creation of irrigation districts with power to construct or purchase irrigation works, to issue bonds and levy taxes, and do everything necessary for the construction and operation of irrigation works. It is hoped that this law will tend to the consolidation of rival ditches and to a larger extension of the principle of coöperation; but it has not been in force long enough to determine whether these results will follow.

Taken as a whole, the Colorado irrigation system is worthy the study of those interested in irrigation in every other arid State. The administrative features are worthy of general adoption; the method of adjudicating rights needs amendment. 


\section{CHAPTER IX}

\section{IRRIGATION IN CALIFORNIA}

From the time the mission fathers turned the streams of California on the thirsty soil, irrigation has shown a mingling of altruism and selfishness. In no part of the world has the practical irrigator shown greater economy and skill, and nowhere has the profession of the civil engineer won greater triumphs in the storage and diversion of streams, but at the same time there have arisen controversies over water rights, which have been as expensive as they were unnecessary. Ability and success on the part of water users have been hampered and endangered by legal and social abuses, which the experience of all irrigated coun-, tries has shown to be fatal to enduring success.

The great success which irrigation has attained in the face of these drawbacks has been due to the fact that nature has done much for the farmer in California. No other State has as diversified products or as highly-priced farming land. The usual limitations imposed by latitude are here set aside. The leading irrigated districts of both northern and southern California have the unique distinction of being able to grow all the products of New 
England and Florida on the same acre of land. Date palms grow in the latitude of southern Illinois, and oak and orange trees shade the same blue grass lawn. The summers are not too hot for the turf nor the winters too cold for the trees. In this favored country there is a wet and a dry season. Winter is the season of rain and is the growing season for many of the products of the temperate zone. The rainless season comes during the period of harvest and fruitage. Grain ready for the reaper may stand uninjured for months. The curing of forage is attended with none of the uncertainty or risk of loss which attends this work in humid districts. It is hard to estimate how much a cloudless sky has done toward developing the fruit-growing industries of California. Especially is this true of the dried fruits : peaches, prunes, apricots, nectarines, raisins, and figs could nowhere else in this country be dried in the sun with the safety and cheapness that attends this work in California.

The climate of California has made it one of nature's great sanitariums. The clear skies, the bright sunshine, and the even temperature of both winter and summer, are southern California's greatest asset. The riches of the mines and the fertility of the soil have their counterpart in the wealth of scenic beauty which the State possesses. To the charms of the ocean are added the attractions of the snows and wild and rugged canyons of the Sierras. In all parts of the State, these are 
so near at hand that they can be enjoyed by those of the most slender means.

To the marvellous possibilities of the climate there is added a soil of great fertility, with a surface smooth and easy of tillage. This is true of California in general, but it needs to be qualified by the statement that in no State in the Union is there a greater diversity in the character of the soil, or greater need of understanding its management. In much of the cultivated portion of the State irrigation is not a matter of necessity but of choice. A farmer may irrigate his garden and leave his wheat field to the rain. This is especially true of northern California. The windmills around Stockton mark the limits of irrigation. Beyond this the land is still cultivated, but it is watered from the clouds. In the Santa Clara, San Joaquin, and Sacramento valleys, one passes a constant succession of vineyards and orchards, some of which are irrigated and some are not, yet all appear flourishing. Nevertheless, no State has gained more than California from the artificial application of water, or has more at stake in the extension of its use. It is only through its magic that all of the possibilities with which the State is so generously endowed can be brought into full fruition. Through irrigation, midsummer can be made almost as lovely as spring. It removes or lessens the dust and discomfort of the rainless season and makes it possible to create rural homes, which, on the whole, represent an 
average of human comfort hardly to be equalled elsewhere in this country. It completes the marvellous combination which makes winter a season of seed-time instead of stagnation, which gives to the farmers many of the products of the tropics with the climate of the temperate zone, which withholds moisture when it is not needed and thus relieves the husbandman of the most serious vicissitudes of humid districts. This is an aggregation of advantages which those who live elsewhere find it hard to believe exists, and which at home is not everywhere fully appreciated.

The figures of the twelfth census furnish an appropriate starting-point for considering the irrigation laws and customs of California. According to these, there are now 25,675 users of water in irrigation, of which over 18,000 are supplied from streams and nearly 7000 from wells. Altogether, I,446, I I 4 acres of land are irrigated, of which I 52,506 acres are supplied from wells. The total number of ditches is put down as 99i 3 and their total cost is given as nearly $\$ 13,000,000$. It is believed that the actual outlay is nearer $\$ 20,000,000$ than $\$ I 3,000,000$, but the number of dollars invested is of less consequence than a clear understanding of the nature of the right of each user of water, how it was acquired, and how it is protected.

Taken by themselves, the figures given convey no real impression of what irrigation is doing for California. In order to realize this, one must go 
to the southern part of the State, where lands which were once not worth $\$$ IO an acre have by irrigation been made worth $\$ 1800$ an acre, where water which once ran unused to the sea now sells for $\$ 1250$ for a single inch, where the water rentals on an acre of land have at times exceeded the purchase price of an acre of first-class falming land in Iowa. The citrus industry, which affects not simply southern California but the markets of every important city in the United States, is the creation of irrigation, but great as it is, it is not the chief benefit which irrigation has brought to this part of the State. A large gain has come from the beautiful landscape which these oases of fruit and foliage present and which have done as much to create the cities of Los Angeles, Riverside, Redlands, and Pasadena as their delightful climate. The crowds of health and pleasure seekers which each year visit this section would find little to attract them if every valley depended solely on rainfall for its water-supply and in summer was still brown, dusty, and arid.

Irrigation in northern California is of more importance for its possibilities than its achievements. For nearly a half century the greater part of the land of this region has been devoted to the unremitting production of cereal crops. Each year the grain has been shipped away and the straw burned. Little or nothing has been done to restore the fertility of the soil. Although this surprising drain has gone on for fifty years, it cannot con- 
tinue forever. There must be a change, rotation of crops must be introduced both to maintain the fertility of the soil and to render agriculture less hazardous and more profitable. Such rotation is not possible by rainfall alone. There is neither enough water nor is it rightly distributed. While the dry season is one of the State's greatest advantages when combined with irrigation, it is a great obstacle when agriculture is attempted without irrigation's aid. It is possible to make California one of the richest agricultural States in America, but to do this requires that every river shall be diverted, that the floods shall be stored, and that every drop of the available supply shall be used. It is unfortunate that the laws, as they exist to-day, do not furnish adequate protection or security for any such development.

In much of California, irrigation, while of great value, is not a necessity. Neither the bonanza wheat farm nor the cattle ranch - the two agricultural industries which first became prominent in California - require it. Both of these had a fascination which made their owners object to a change. The pictures of the early cattle ranches by Bret Harte, and the story of the wheat farm by Frank Norris, make it plain why the coming of the irrigator was looked upon with disfavor. The owner of the ranch herd was more than a money-maker. He often ruled a territory larger than some States. The bonanza wheat farm suited the spirit of men who loved large undertakings. Wheat-growing 
was spectacular as well as profitable. The irrigator working in the mud, under the sun of the California summer, was not an attractive object, and the cattlemen along King's River threatened to lynch the first builder of a ditch on that stream.

For many years irrigation in California was considered a private matter. If one man chose to irrigate his land, that was no concern of his neighbor who farmed without the aid of streams. The large estates of California strengthened this tendency. Some of the canals built by their owners to water their own property would in other States serve to water one hundred farms. The CrockerHuffman Canal and the Calloway Canal each cost over $\$ 1,000,000$, yet they irrigated only a part of the land of their builders. The community looked on these works as private ventures, differing only slightly in character from the barn, the winery, or roads which formed a part of these estates. Much of the land now divided up into small tracts was originally owned by a single individual, who built canals to fertilize it and then sold the land and water together. In this way many of the districts now farmed under coöperative irrigation works were originally a single private estate.

Some causes which led the people of California to look upon the building of ditches as a private matter caused them to regard the struggle over the ownership of streams in the same light. Many did not wish to irrigate, and they looked with indifference on the appropriation of streams by those 
who did. As ditches multiplied and appropriators failed to agree upon a division of the water-supply lawsuits arose, but these controversies did not interest the public. Those who owned irrigation works were apparently willing to fight for the control of the water which filled them, and those who were not irrigating took little interest in the troubles of those who were.

The true conception - that water is public property; that whoever diverts it is a public servant; that whoever uses it in irrigation is a public benefactor; and that rights to control streams can only be exercised wisely and safely under public supervision - has been of slow growth in California.

The dedication of streams to the use of the people of the State, as in Colorado, has no place in the laws of California. Nowhere else in the arid region has private enterprise gone so far nor public neglect been so pronounced. Not only has the State failed to assert control over streams, but many able attorneys say that no such control can be exercised. This makes water the subject of an unending warfare, which does not change in character whether it is waged with shotguns and shovels on the banks of ditches or by means of injunctions in the courts.

The few water laws of California are confined to general declarations, which have little practical influence because no means have been provided for carrying them into practical operation. The statutes say " that the right to running water may be 
acquired by appropriation, which must be for some useful or beneficial purpose," and that when this right ceases to be used it is lost. But there is no method by which interested parties can learn how much water has been used nor what rights have been abandoned.

These rights already affect the prosperity of many thousands of people and are destined in time to have a vastly greater importance, but a simple declaration that they exist will not divide streams among users any more than a knowledge of the ten commandments will cause men to follow their teachings. Protection of irrigators requires the division of the state into drainage districts and the appointment of officers to divide water between appropriators, in order that peace and stability may prevail.

The laws of California require parties intending to appropriate water to post a notice stating what they claim, the purpose for which it is claimed, the means to be taken to divert it, and the size of the ditch, flume, pipe, or aqueduct which is to be constructed. It also requires that this posted notice shall be recorded, but does not require that all these records shall be in one place. Instead, they are recorded in whatever county the head-gate is located. The recorder who receives this notice is elected to perform other duties, and has no authority to reject an improper claim and is not required to see that any of them conform to the actual facts. In some counties he has a book to which any approI 88 
priator of water has access, and in which he writes whatever he pleases.

As no examination is ever made to determine whether or not the ditches described in this record are actually built, they neither protect actual users of water nor give warning to intending investors in irrigation works. So far as practical results are concerned, all who are interested would be fully as well off if not a single claim had ever been recorded.

These records are rendered still more useless by the fact that rights to water can be acquired by prescription without any record being made. Five years' use of water without notice to other users gives the same right as if this notice had been recorded.

The character of these records in California are not unlike those elsewhere. There is the same uncertainty of statement; the same tendency to claim extravagant amounts of water; the same grotesque misuse of the units of measurement. ${ }^{1}$ Where it is too much trouble to make an esti-

1 The luminous fact which appears strikingly on the face of these statistics is that nobody knew how much water was available for appropriation, how much they needed, or, in case of those who followed up their claims with actual diversion and use, how much they received. The evils to result from such methods might be expected to make themselves felt when the country is well settled, and it becomes necessary to enforce the utmost economy in the use of the water-supply. - William E. Smythe. Irrigation Problems of Honey Lake Basin, Bulletin 100, Office of Experiment Stations, U. S. Dept. of Agriculture. 
mate of the water to be used, the whole stream is claimed. In some cases this is made more comprehensive by claiming all the water below ground as well as above. In Honey Lake Valley the claims to water amount in the aggregate to more than enough to irrigate twice the land that is ever likely to be watered in the United States. The average flow of King's River varies from 5000 to I0,000 cubic feet per second in flood season, and between 500 and 1000 cubic feet per second during the low period. The claims to the water of this stream amount to 750,000 cubic feet per second, exclusive of a large number of claims to the entire supply. The San Joaquin River has a discharge of approximately 6000 cubic feet per second. The notices recorded claim 914,286 cubic feet per second.

Under the code of California, the right of appropriation is limited to running water flowing in a river, stream, or down a canyon or ravine. Percolating water is not subject to appropriation, it being held to belong to the soil. The distinction between running water and percolating water is of great practical importance. In southern California and in certain sections of northern California, there are hundreds of wells from which water is pumped and large investments have been made in tunnels and bedrock dams to utilize underground supplies. If the water secured is running water, it is subject to appropriation, but if it is not running water within the meaning of the code, it belongs to the land- 


\section{IRRIGATION IN CALIFORNIA}

owner and no right to its use can be acquired by others. ${ }^{1}$ In every case there is an element of uncertainty as to whether the water pumped is drawn from what is stored in the soil or from subterranean streams which are intercepted, and there is no way of legally determining this in California except through litigation. The occasions for such litigation are being multiplied by filling up the subsoil with water from irrigation ditches.

Before irrigation began in the San Joaquin Valley the water-bearing strata was seventy feet below the surface. In the irrigation season it is now less than seven feet from the surface in many localities. Pumping, which would have been unprofitable in the first place, is now being largely adopted because of the diminished lift. This creates a new question. Have the canals which fill this subsoil any claim on the water it carries?

Another perplexing problem connected with the use of underground water-supplies is the fact that many streams which flow on the surface in the mountain canyons sink into the gravel of their débris fans when they flow out into the valleys requiring irrigation. Tapping these gravel beds has been a favorite and successful method of

1 We therefore hold it to be the law, and we think it to be a moderate and just exposition thereof, that one may, by appropriate works, develop and secure to useful purposes the subsurface flow of our streams, and become, with due regard to the rights of others in the stream, a legal appropriator of waters by so doing. (Vineland Irr. District v. Azusa Irr. Co., 126 Cal., 486.) 
developing water in California during the past few years, but in some instances this underground water again comes to the surface farther down the stream, and the question has arisen as to whether the use of underground supplies above does not interfere with the rights of appropriators of the surface waters below.

There is another interesting question connected with the use of underground water. There are over I 500 pumping plants in the Santa Clara Valley. Their operation lowers the water-plane of that valley during the irrigation season. Before this lowering took place the roots of trees in many orchards reached the underground water-supply and did not require irrigation. Now they do not reach it, and irrigation has become a necessity. Thus the surface irrigation of one orchard may lower the waterplane in an adjoining field. It is thus possible for one man to rob his neighbor of his water-supply, and this raises the question whether there should not be priority of right to underground as well as surface supplies, regardless of whether they flow in a well-defined channel or are percolating through the soil.

\section{Riparian Rights}

In 1850 , the legislature of California passed a law which makes the common law of England apply in all cases not in conflict with the law and constitution of California, or the Constitution of the United States. Under the statute, it has been held 
that the common-law doctrine of riparian rights applies to California streams. In I85 I a law was passed providing for the appropriation of water, and this was generally regarded as abrogating riparian rights, repealing by implication the earlier statute, at least so far as irrigation was concerned, and it was not until nearly twenty years later, and after millions of dollars had been invested in irrigation works, that this question was raised. In the historic decision of Lux $v$. Haggin, it was held, however, that riparian proprietors have vested rights in streams, but this decision, while recognizing the supremacy of the common-law doctrine, modified it in such a way as to legalize the irrigation of riparian lands. Because of this modification, the economic import of the decision has not been what was feared at the time, ${ }^{1}$ and its influence has been still further changed by

1 Every practical man must know that, with the dry atmosphere and porous soils of those sections requiring irrigation, but little, if any, of the water diverted and used in irrigation is, or can be returned to the stream from which it is taken. To establish, therefore, as the law of this State, that the water of a watercourse must flow on in its natural channel, undiminished in quantity, would in effect be to convert the fertile fields, gardens, orchards, and vineyards in many and great sections of the State into waste and desert places. Such a rule is inapplicable to the conditions of things existing here. The common law is supposed, and has been said to be, the perfection of human reason, but it would be the very reverse of this to hold that the waters of the streams of California must continue to flow in their natural channels until they sink into the sands or waste themselves in the sea, while orchards, vineyards, and growing crops of immense, if not incalculable value, perish from thirst. - Extract from dissenting opinion of Justice Erskine M. Ross. 
subsequent decisions, until to-day the rights of a riparian owner are more like those of a preferred appropriator of water than those of a riparian proprietor under the common-law doctrine as it is generally understood elsewhere.

Owners of riparian land have not only diverted and used rivers in irrigation, but have rented and sold the water claimed under the riparian doctrine to those who irrigate non-riparian lands, and the right to do this has been sustained in repeated judicial decisions. ${ }^{1}$ This has led these proprietors to assert a right to the entire supply, not only for the irrigation of all lands they own, but to what they can dispose of to non-riparian neighbors.

In speaking of this modification of the common law doctrine, Hon. John D. Works, a distinguished law writer of California, has said :-

"But this, again, is wholly inconsistent with the commonlaw right, which is a part of the land to which it is annexed. Of course he could grant or convey his right with the land of which it is a part, but not otherwise, because when severed from the land it is no longer a riparian right, but that right is wholly destroyed. Therefore, it is certainly an error to say that a riparian right may be conveyed separate from the land. The party to whom the conveyance is made may obtain the right to the use of the water, but it is no longer a riparian right." 2

The doctrine of appropriation and the commonlaw doctrine of riparian rights are directly antago-

${ }^{1}$ Gould $v$. Stafford, 9I Cal. 146. Alta Land Co. $v$. Hancock, 85 Cal. 219. Sprague $v$. Heard, 90 Cal. 221.

2 Works on Irrigation, pp. 23-25. 
nistic, yet both are a part of the irrigation system of California. Under the former, appropriators have claimed the entire flow of streams and provided for the distribution and use of the water. On the same streams riparian proprietors claim a preferred right to the entire flow, regardless of whether they use it or not.

The absence of any definite limitation on riparian rights creates a serious menace to large investments in irrigation works. The Sweetwater and Hemet reservoirs are both large and costly storage works. Both have been compelled to defend vexatious and expensive lawsuits brought by owners of riparian land to compel their destruction. In each case the failure of these suits was not due to a reversal of the riparian doctrine, but to technical blunders made by the plaintiffs in the litigation. If the riparian doctrine is to be maintained, there should be an early definition of what are riparian lands, in order that other users of water may know the extent of the preferred claims to the water of California streams. Irrigators need to know whether or not the owner of 640 acres of land, which has a few hundred feet frontage on a creek, can irrigate the entire section as a riparian proprietor, while the owner of 40 acres of land, which fails to reach the stream's bank by a few feet, is denied the right to water.

Many of these rights are being exercised in an arbitrary fashion, and the property in water is of a purely speculative character. Wherever a riparian 
proprietor objects to the use of water above, only litigation can determine whether or not the objection is justified. If he is so disposed, a riparian owner can be a menace to actual users, even if he does not levy tribute upon them.

In the decision which recognized riparian rights, it was held that the evils of the riparian doctrine were less to be feared than those which might come from the acquirement of speculative rights under the doctrine of appropriation. ${ }^{1}$ There is no question but what there was some basis for this fear, but the establishment of riparian rights does not provide a remedy. It has in it the germ of natural justice so long as the rights are attached to the land and do not become the property of the owner of the land. The danger of monopoly lies, not in the doctrine of appropriation, or in the doctrine of riparian rights, but in making water rights personal property, which can be held and trans-

${ }^{1}$ In our opinion it does not require a prophetic vision to anticipate that the adoption of the rule, so-called, of "appropriation" would result, in time, in a monopoly of all the waters of the State by comparatively few individuals, or combinations of individuals controlling aggregated capital, who could either apply the water to purposes useful to themselves, or sell it to those from whom they have taken it away, as well as to others. Whether the fact that the power of fixing rates would be in the supervisors, etc., would be a sufficient guarantee against overcharges would remain to be tested by experience. Whatever the rule laid down, a monopoly or concentration of the waters in a few hands may occur in the future. But surely it is not requiring too much to demand that the owners of lands shall be compensated for the natural advantages of which they are to be deprived. ( $69 \mathrm{Cal} ., 310$. 
ferred without regard to the ownership of the land.

The greatest boon which could be conferred on farmers and ditch-owners of California would be relief from the anxiety and expense of litigation over water rights. Two examples will show the extent of this menace to future development. The litigation over the water rights to Los Angeles River has been going on for more than thirty years. The first suit was between the city and two riparian proprietors claiming two hundred miner's inches of water. It was decided in favor of the two landowners and no appeal was taken. After waiting a number of years, the city brought a second suit, which was also decided in favor of the two landowners. This time an appeal was taken to the supreme court and a ruling made that the contention of ownership in the stream made by the city had no support in evidence. In April, I88 I, the city became engaged in a contest with other riparian proprietors. This was appealed to the supreme court, which decided that the claims of the city to all the water of the Los Angeles River " had been recognized by all the persons interested from the head of the stream and along its banks, including the plaintiffs." This was a reversal of the earlier decisions of both the lower and higher courts.

Since I88I, there have been three lawsuits contesting the city's pueblo right, dating back to $178 \mathrm{r}$. The last decision in these cases was rendered in 


\section{IRRIGATION INSTITUTIONS}

I 899. Whether this decision will stand remains for the future to determine, as a suit is now pending over what the river includes. The trial which recently closed occupied the court for seventy-two days. The testimony taken filled nine thousand type-written pages.

Another illustration of the possibilities of waterright litigation in California is furnished by Cache Creek in Yolo County. So far as natural advantages go, there are few places in this country which equal the valley of this stream. The following description ${ }^{1}$ does not overstate its possibilities : -

"We have here a country of marvellous possibilities, a soil rich in all the elements of plant growth, with surface smooth and easy of tillage, a climate whose summer heat and winter cold are tempered by the breezes of the Pacific, so equable that here all the choicest products of the temperate zone and of the subtropics are grown alike in perfection. Here flourish side by side the apple, the peach, the pear, the plum, the apricot, and grape, along with the orange, the lemon, the lime, and the fig. Here the oak and the pine, there the palm and the pepper tree. The roses bloom winter and summer. The orange carries its fruit through the winter, the oleander is a tree and the heliotrope a hardy shrub."

To make use of these resources irrigation is necessary. The natural rainfall of the country will not answer. The land that is irrigated is worth from two to four times as much as the unirrigated land which adjoins it. Notwithstanding

1 Professor J. M. Wilson. Irrigation from Cache Creek, Bulletin 100, Office of Experiment Stations, U.S. Department of Agriculture. 
this, only a small fraction of the water is being used. This is not due to physical obstacles. Cache Creek is a large stream in the early part of the year, and Clear Lake, at its head, could be made into a valuable storage basin. Nor is the failure to use this water due to lack of appreciation. The dwellers in this valley have made repeated attempts to build ditches and turn the water on their farms. The first ditch was built in I 856 , only nine years after the building of the first ditch in Utah. It is not known how much it carried, but probably not to exceed fifty cubic feet of water per second, while the stream carries at times over one thousand cubic feet per second. Four years after the ditch was built its owner asserted a right to all the waters of the stream, basing the claim on the ownership of a Mexican land grant through which the creek flows.

In I860 a number of farmers of the town of Yolo spent $\$ 75,000$ building a second ditch. It was below the one first built, and could take only the water that the earlier appropriator left in the stream. In I864 the upper ditch was enlarged, and the increased diversion reduced the watersupply of the lower company, which sought the protection of the district court. The suit thus begun in I864 dragged along in the courts for ten years, when a decision was rendered giving the owners of the lower ditch enough water to supply it. In the supreme court this decision was reversed, and the lower ditch went out of 


\section{IRRIGATION INSTITUTIONS}

business. Having no right to water, it was simply an obstruction, and has been largely obliterated.

In I87I another company began a ditch and completed it in 1874. Two years later it became involved in litigation with the owner of the first ditch, in which the plaintiff was nonsuited. Two years later another suit was begun; in this the plaintiff was again defeated. Two years afterward a third suit was begun in which the original appropriator obtained a decree to a continuous flow of 432 cubic feet of water per second. What guided the court in fixing this amount of water cannot be ascertained, because the testimony was never transcribed. It was not based on the capacity of the ditch, because it will not carry one-fourth this volume. It was not based on the flow of the stream, because measurements made in June and July of 1900 showed it fluctuated between 88 and 189 cubic feet per second. This case was appealed to the supreme court, where the judgment was confirmed.

Another ditch had to be abandoned with a loss to its owners of about $\$ 150,000$. The loss to the community was far greater.

In 1877 another ditch company, unmindful of the experience of its predecessors, or perhaps hoping for a more fortunate outcome, began a ditch. In 1882 the claimant of the first right brought suit for an injunction to restrain this company from interfering with his control of the stream. The case came to trial in 1888 and dragged its slow 
length along, while volume after volume of testimony, exceptions, and objections was being filed. Before it was completed the presiding judge was taken ill and a court commissioner appointed who added two more volumes to the testimony previously taken. The final result of this litigation is well stated by Professor J. M. Wilson, who prepared the report from which these facts have been taken :-

"To find any capable jurist who would undertake the appalling and thankless task of digesting all this accumulation of fact and theory, exception and objection, and who was acceptable to both parties to the controversy, was not easy. Twelve years have passed, and no referee on whom the contending parties have been able to agree has ever been willing or has found time to take up the matter and reach a decision. The cherished hope of the men who built these works of an improved husbandry, which should restore and perpetuate the fertility of their fields, failed. The vision of meadow and pasture and orchard and vineyard and garden and pleasant homes vanished. In its place continued the dull round of ploughing and sowing and reaping wheat, while diminished production keep pace with soil deterioration.

"Through all these years the temporary injunction issued thirteen years ago continues in force. The Capay Ditch has been ploughed in and the Adams Ditch is a wreck, irrigating about twenty acres and carrying a little water for stock.

"If the history of this 'chosen valley' was different from others we might look for the cause of all this dismal failure in the character of the people who have been engaged in these enterprises, but the managers or promoters of these failing ditch enterprises were not weaklings. Their quality is approved by their success in other lines before and since. Their fault was a too great faith in a system which was only lack of system, whose pretended regulation gave only fancied 


\section{IRRIGATION INSTITUTIONS}

security at first, to later add to their embarrassment. Everywhere, all over California, wherever there has been enterprise enough to attempt to use the water, the story is the same. The energy and capital of water users and appropriators are consumed in litigation. The cause is not in the people who seek to utilize the water, but in the law regulating the appropriation and use of water."

In order to avoid experiences of this character and to live in peace with one another, appropriators of water have, in many instances, entered into private agreements which mutually recognize' each others' rights. In all such agreements there must be a tacit assumption that the water of the stream belongs to nobody but those claiming it, and an entire disregard of the rights of the public whose interests are so vitally affected and of those appropriators who were not represented. While these understandings are far to be preferred to a legal warfare such as has been described and too often experienced, there is always a danger that in such divisions more water may be conceded to each claimant than has been put to beneficial use, and a foundation laid for obstructing future development or for laying unjust tribute on those who may attempt to use water in the future.

These agreements are sometimes given added legal sanction by friendly lawsuits in which decrees, confirming the rights claimed, are rendered. This would be a step in the right direction if the statements presented to the court were first verified by some impartial and expert examination of the 
stream and some accurate measurement of the uses made of the water and the necessities of these uses. At the best, however, they can only be considered as makeshifts and temporary expedients. They are not a final settlement because new rights may be acquired at any time by prescription, and it is rare that they settle all existing controversies because an unwilling appropriator cannot be compelled to submit his claim or abide by the result. Under the laws of California it is possible for A to compel $\mathrm{B}$ and $\mathrm{C}$ to appear in court and litigate their rights with respect to his own, but it is not possible for $\mathrm{A}$ to compel $\mathrm{B}$ and $\mathrm{C}$ to litigate their rights with respect to each other. There are few, if any, streams in California where the relative rank of all appropriations has been established. The farmer whose present and prospective prosperity depends on his water-supply is rarely secure in his position.

That a development so important and extending over such a long period of time could have taken place without these matters being finally settled, is largely due to the fact that appropriators prefer to submit to a certain measure of injustice rather than to enter upon expensive litigation, and the long absence of public supervision has begotten a fear of its results. The present situation of affairs cannot, however, continue indefinitely. As the demand for water increases, the evil results of permitting every water user to regulate his own affairs will become more and more apparent. 
There will be an increase in injunctions to shut down head-gates on up-stream canals. This, while effective, does not permit of the regulation and modification necessary to secure the most economical use of the water, which can be guaranteed only by placing streams under competent administrative control.

The present situation is unjust to the small appropriator and gives a dangerous advantage to his more wealthy and litigious opponent. The expenses of a lawsuit are practically the same, whether the water right sought to be maintained is for ten acres or for a thousand acres. It is the small irrigator who has the greatest need for a definition of his water right, and in order to secure justice to him and to the public, it must be determined under what conditions each user shall receive water, how much he shall receive, and how he shall be protected in times of scarcity.

The history of the water-right litigation before referred to is typical of what has been going on on every stream where water is scarce and valuable. The cause is to be found in the failure of the State to discharge its duty toward those who create wealth when they put water to use in irrigation. This duty will never be performed so long as it leaves any one in doubt as to what is his just share of a stream's flow, or puts upon him the entire expense of defending that right when it is assailed. Users of water ought to be protected in their rights by the public authorities. The expense of this 
should be paid for by public taxation. It is the only way in which justice can be assured, and the largest and best use of the water-supply obtained. Leaving the ownership of streams to be fought over in the courts and titles to water to be established in ordinary suits at law has never resulted in the creation of satisfactory conditions, and never will. Under present conditions the same issues are tried over and over again. Each decision, instead of being a step toward final settlement, too often creates new issues which in turn have to be litigated. The suit of one canal company against another company may settle the rights of these companies as against each other, but it settles nothing with respect to other appropriators not made parties to the litigation, and the whole controversy may be opened up at any moment. A stream with three appropriators has the foundation for at least three lawsuits: A v. B; $\mathrm{A} v . \mathrm{C}$; and $\mathrm{B} v$. C. If there are four appropriators the way is open for six adjudications. Often the appropriators from a stream are numbered by scores and even hundreds. It might be interesting to compute the number of legal conflicts necessary to a judicial determination of the relative rights on streams like the Sacramento, and these will, under the present procedure, increase with years, because there will be new appropriations, and old ones will be extended. It is not surprising that the petition for an investigation by the people of California should state that the 
litigation is appalling. It could not be otherwise. The absence of public control makes litigation as natural a product as are weeds in a neglected field.

There can be no stability under the present situation. The law affords no means of enforcing a right when once adjudicated except through another lawsuit. Irrigators cannot live in peace. Litigation and controversy are forced upon them. To acquiesce in a new diversion, through sympathy or for the sake of peace, may lay the foundation for an adverse right by prescription, and end in the curtailment or the overthrow of all the rights of the peace lover. This uncertainty and the fear of being supplanted which grows out of it is the cause of much of the hostility with which appropriators regard new ditches and is the motive behind much of the extravagance and waste which sometimes prevail in the use of water. With a right clearly defined and protected its owner has no fear of shortage in time of need, and he is willing, when his crops do not require water, to have it utilized by others; but when the right is insecure or not defined the instinct of selif-protection makes an Ishmaelite of every water user. His hand must be against every man as every man's hand is against him. Duty to himself and to those dependent upon him makes it necessary, that he shall use all means at his command to discourage the establishment of rights which may later interfere with his necessary use of the water. Under such a system every new appropriator is a new 
element of uncertainty and another menace to the peace of the community.

The whole system is wrong. It is wrong in principle as well as faulty in procedure. It assumes that the establishment of titles to the snows on the mountains and the rains falling on the public land and the water collected in the lakes and rivers, on the use of which the development of the State must in a great measure depend, is a private matter. It ignores public interests in a resource upon which the enduring prosperity of communities must rest. It is like A suing $B$ for control of property which belongs to $\mathrm{C}$. Many able attorneys hold that these decreed rights will in time be held invalid because when they were established the public, the real owner of the property, did not have its day in court.

The responsibility for this situation rests first of all with irrigators and ditch-owners. It arises from their reluctance to submit to any sort of supervision or to effective control of streams. Although attorneys and judges have had much to do with these controversies over water rights, they are in no sense responsible for their creation. In fact, under the present situation, the courts are the only protection against a rule of force or anarchy. At present no class of citizens are doing more to reform the irrigation laws than attorneys. Wherever they have been appealed to they have given their time and influence to promote the success of investigations looking to reforms. One of the 
ablest arguments thus far presented in favor of a special tribunal to make a final determination of all existing rights was made by a judge who, through painful experience, had become impressed with the danger of leaving these matters to be settled by litigation, in which it often happens that all the issues involved are not fully presented, and where the failure to do this always includes the judge among its victims.

The contrast between the conditions which governed the early use of water in California and in Colorado is not greater than the differences in present methods. It seems somewhat remarkable that the two leading irrigation States of the West should be so unlike in the character of their water laws and irrigation customs. For administrative purposes Colorado is divided into districts based on drainage lines; there are no such districts in California. In Colorado all the rights to water in a district are determined by a comprehensive judicial proceeding so that every appropriator of water knows both the amount of his right and its relation to other appropriations from the same supply; there is no provision for reaching such a result in California. In Colorado the rights of prior appropriators, when established, are protected in times of scarcity by the public officials ; in California each appropriator has to scramble for all he gets, regardless of his rights. In Colorado the State engineer's office is an office of record for all rights to water from all streams, and the State engineer 208 
measures the available water-supply and supervises its distribution; in California there is neither such a place of record nor such an official. These comparisons are not intended to show the superiority of one State over another, but rather to illustrate how Western irrigation has been shaped by local influences rather than by prearranged plans; but from many conversations with irrigators in both States there is no doubt that the order and system of Colorado have been of great service to the users of water, that growth and prosperity have been promoted, and discord, friction, and anxiety have been lessened through their influence. No one in Colorado would think of doing without the services of the water commissioner, nor can irrigators there understand how it is possible for water users in California to live in peace with each other without the assistance of some such arbiter.

Under a rational irrigation code titles to water are established like titles to public land, by proceedings which are wholly ministerial. This is the case under the Northwest Irrigation Act of Canada and under the Wyoming irrigation law. The latter will be discussed in a subsequent chapter.

\section{Irrigation District Law}

The difficulties encountered by individuals and corporations in the construction and operation of irrigation works led, in 1887 , to the passage of 
what is generally known as the Wright Act. It provided that all of the land susceptible of irrigation from the same system of works might be organized into a district resembling in some respect municipal organizations, and these districts could be taxed to pay for ditches and canals to water them. These districts were authorized to acquire and own real estate, purchase water rights, and purchase or build ditches and canals, and to issue bonds to raise the necessary funds. It was hoped in this way to bring about the breaking up of large estates, or at least to prevent their owners from obstructing the development of other lands. To this end all lands benefitted were to be taxed to pay for the works built, and the law was framed in such a way as to give great power to those who were favorable to construction and to restrict the power of the opposition.

A petition of fifty freeholders was sufficient to begin the organization of a district. In the voting on districts, the owner of ten thousand acres of land had no more voice than the owner of ten acres. If the project was approved by the board of supervisors, the district was authorized to issue bonds which became a lien on the lands of those who opposed the district as well as those who favored it. In this way it was made possible to place such a burden upon farms as to result in their confiscation if the irrigation projects did not prove a success. 
There is no question that the purpose behind this law was a praiseworthy one. It sought to put an end to the speculative ownership of water and to remove the obstacles to construction which were harassing ditch-builders. Unfortunately, in the effort to frame a law which would override all obstacles the safeguards against abuses were disregarded. The trustees of many of these districts had to assume large responsibilities and conduct large enterprises. In some instances, men who had probably never expended $\$ 500$ in their lives were called upon to direct the outlay of $\$ 500,000$. The result was that they made many errors of judgment and in some instances were deliberately dishonest. Mistakes were made in the estimates of cost, these nearly always being below the truth. Worthless water rights were purchased at extravagant prices. When the first issue of bonds was exhausted and new issues were necessary to complete the work and give it any value, it was found difficult to dispose of these under the conditions of the State law, which required that they should not be sold for less than 90 per cent of their face value. The interests opposed to the districts fought them vigorously, and to a greater outlay for construction than was anticipated was added an unexpected and large outlay to meet the expenses of litigation.

In an effort to overcome these obstacles and proceed with construction the law was constantly evaded. Bonds were sold to third parties in order 
to be passed from the districts to contractors, who could not receive them in direct payment for work done. Work was contracted for at high prices in order that bonds could be disposed of at par and still compensate the contractor for his outlay. Waterworks were constructed at private expense with the understanding that bonds were to be taken in payment when finished, the law permitting works to be purchased in this way. As expenses augmented and taxation to meet interest charges became burdensome, landowners organized to evade the payment of these obligations by attacking the validity of the law or the action of the trustees. The irregularities growing out of mismanagement or inexperience gave great opportunities for doing this, and although the constitutionality of the law has been sustained, many of the districts have been declared invalid.

The outcome of this law is much to be regretted. It is difficult to estimate the benefits which California would have derived during the past ten years if the works planned under these districts could have been completed and put into successful operation. It is certain that millions of dollars would have been added to the State's taxable and productive wealth. There is much in the theory of this law to commend it. It involves the idea of local self-government, it retains under the control of farmers the water which they use, and prevents local rivalries and jealousies, which are so likely to arise between irrigation works constructed by 
individuals or corporations. The failure of the Wright Law must not, however, be charged entirely to the act. The conditions under which it operated must also be taken into account. If there had been a State engineer to pass upon the adequacy of the water-supply and the reasonableness of the estimates of cost, many of the errors made would have been averted. One mistake in the law was that it allowed a vote to all residents entitled to the ballot for other purposes, and this mistake has been rectified in similar acts passed elsewhere. Only property owners should have had a voice in the formation of districts and in the issuance of bonds, and voting should have been proportional to the property represented.

After the panic in 1893, many of the works begun were practically abandoned, but within the last two or three years efforts have been made to revive construction, and one of the most important, the Turlock Irrigation Canal, has been completed. Work has been resumed on a number of other important irrigation projects, and it is believed that much of the expenditure, which at one time was regarded as absolutely lost, will in part be made productive. The lesson of the Wright Law is the lesson of irrigation in all countries and at all times. There can be no peace and stability among irrigators without public administration of the streams from which the water-supply is taken. 


\section{IRRIGATION INSTITUTIONS}

\section{Fixing Rates}

The subject of rates for water furnished to irrigators has provoked more controversy in California than in all of the other States combined. This is due in part to the great value of water. The statute gives to boards of supervisors in counties in which water is sold, the right to regulate rates, and requires that rates shall be so fixed as to yield a fair return on the investment, but there is great difficulty in determining this. The earning capacity of canals is the chief factor in fixing the value of property, but this capacity in turn is largely determined by the rates charged for water. The causes which lead to differences of opinion regarding what are reasonable rates are discussed elsewhere and need not be considered further here.

Another objection to the law is the fact that some canals cross county lines. Supervisors of one county are not bound by the acts of another, and it is possible to have two sets of rates for water from the same works. The remedy would seem to be to remove this power as far as possible from all local influences by creating some general authority like the State engineer's office.

Many of the controversies about water-rates involve more than the question of rentals. A large part of the water supplied to irrigators is delivered on contracts. In many of these contracts, the payments for water include two items. 


\section{IRRIGATION IN CALIFORNIA}

A charge is made for the right to receive it and an additional charge for the service of delivering. On the one hand, it is held that whoever appropriated water acquires property which he can dispose of under contract, and the decisions of the California supreme court seem to support this contention, although it appears to be a dangerous doctrine; but in several decisions rendered by Judge Ross of the United States Circuit Court, it is held that water rights are not property and that there is no authority in the laws of California to make a charge for them separate and independent of the rates for the delivery of water. It would seem that there should be no difficulty in reaching a definite conclusion on an issue so momentous, but, although there have been a number of decisions both of the Supreme Court of the United States and of the supreme court of California, the question is yet a controverted one. In one of the latest of these cases, it is held that a water company has a right to contract with a consumer for both the water right and the rates at which the water will be furnished, but that these rates are subject to the regulation and control of the State. If, however, a water right is property, it is difficult to understand how the State can regulate the price which shall be charged or paid for it.

Another important question with reference to water rates in California which remains undetermined is whether the boards of supervisors have 


\section{IRRIGATION INSTITUTIONS}

the power to set aside written contracts for water. This issue has been involved in cases before both the local and United States courts. In the case of Souther $v$. San Diego Flume Company, the circuit court of appeals held that corporations furnishing water for irrigation were private corporations and that contracts entered into with consumers could not be set aside by public officials. While this decision is in accord with the general tendency of California's irrigation development, it seems to be a mistaken one. If the water of streams can be made private property, it is beyond question that those who distribute it can charge what they please for it; but even the laws of California scarcely seem to warrant this assumption, and some of the decisions of the State courts have held to the view that these are quasi-public corporations where they distribute the water of public streams. ${ }^{1}$

The law provides that land once irrigated shall have equal rights with other lands of their class, and cannot be deprived of water at the pleasure of the canal owner. But there is no official to enforce this law. The State offers no direct rewards for economy, and no direct punishment for a failure to secure it, hence appropriators are permitted to make regulations to suit themselves. These, as a rule, are satisfactory; in most instances as liberal to water users as elsewhere. This is not always the case, however. An investigation of this sub-

${ }^{1}$ McFadden $v$. Supervisors, 74 Cal. 57 I. 
ject brought the following results : In reply to the question as to whether or not water had been furnished in the amount needed and at the time needed, out of 47 persons, 43 answered no and 4 answered yes.

Some of the answers to the inquiry as to the length of the delay in receiving the water after it was asked for, were as follows :-

"A few hours;" "Did not have to wait long in 1900;" "Fourteen days;" "Sometimes have to wait;" "Sometimes as long as two weeks;" "Fifteen days ;" "One to three weeks ;" "Twenty days;" "About three weeks after it was needed;" "Three weeks;" "One week to one month;" "Two to four weeks;" "About three weeks;" "Sometimes we have to wait three to four weeks;" "Three to four weeks;" "Always have to wait in August and September;" "The brush dam was put in late and everybody wanted the water before it was ready;" "Three to four weeks;" "About four weeks;" "Four weeks;" "Thirty days;" "Sometimes wait a month or more;" "About one month;" "One month."

\section{The Future Development of California}

A number of works which have slumbered for some years have recently been completed, and every indication points to the construction of a number of other large canals in the near future, especially if there can be such changes in laws as 


\section{IRRIGATION INSTITUTIONS}

will give stability to investments of this character; but in addition to monumental works, California abounds in many opportunities for the construction of small ditches. A single farmer or a few farmers working together can turn creeks upon their land to the benefit of both themselves and the public. The carrying out of these enterprises will be promoted by a law which will give to individuals the power to acquire by condemnation the right of way for such ditches. Rights of way for ditches owned by corporations engaged in the distribution of water to others can now be condemned, but there is no provision for securing rights of way where ditches are built by individuals to water their own lands. There seems to be no reason why this distinction should be retained.

Although a candid statement of the irrigation situation in California has involved some criticism, the situation on the whole is full of hope. Mistakes which have retarded development have not been sufficient to overcome the manifold advantages of the State, nor to prevent both a large development and great prosperity. Instead of being a cause for discouragement, they should be an incentive toward the creation of better conditions, and this is the dominant spirit and temper of the State at the present time. In all parts of the State the sentiment in favor of wise laws and just policies is active and aggressive. The California Water and Forest Association and a number of other kindred organizations have in their mem- 


\section{IRRIGATION IN CALIFORNIA}

bership practically all of the leaders of thought and business in the State, and they are all enlisted in the effort to secure a code of water laws which shall be worthy of the twentieth century and of one of the greatest States in its foremost republic. 


\section{CHAPTER $\mathrm{X}$ \\ IRRIGATION IN UTAH}

WHEN the Mormon emigrants started on their lonesome journey across the arid wastes of the uninhabited West, their first thought was to find a home so remote from human settlement that they could follow their religious beliefs and practices without being interfered with. Locating in an unknown desert, in a region without established government, and where there was question whether sovereignty lay in the United States or Mexico, they had to begin at the foundation in building their commonwealth. Irrigation was necessary because crops could not be grown without it, and it was only through agriculture that they could be saved from starvation. The leader of these pioneers, with wisdom if not inspiration, made agriculture the foundation industry of his people. In this respect, the beginnings of Utah were different from those of every other arid State. Here, agriculture was from the first the principal industry; in many of the others it was, at the outset, a mere incident. Because of its paramount importance, the laws and customs under which it was developed had early a careful consideration and took a different trend from the beginnings in other States. Colorado and California borrowed their early water laws and customs from the miners; Utah made hers first hand. The 


\section{IRRIGATION IN UTAH}

system adopted by the territorial legislature at its first session in 1852 contains some of the best features of the highest development of irrigation law as it is now understood. Public ownership of natural resources, including water, was one of the foundation principles of the State of Deseret, and later of the Territory of Utah, as is shown in the following extract from a statute of the first territorial legislature :-

The county courts shall . . have control of all timber, water privileges, or any watercourse or creek, to grant mill sites, and exercise such powers as in their judgment shall best preserve the timber and subserve the interests of the settlements in the distribution of water for irrigation or other purposes. Grants of rights held under legislative authority shall not be interfered with. (Territorial Laws of Utah, Chap. I, Sec. 38, approved Feb. 4, 1852.)

To carry this law into effect, the court of Salt Lake County, then the centre of settlement, passed the following order:-

Be it ordered, that it shall hereafter be the duty of all or any persons of this county petitioning this court for any right of kanyon or location of county road, or any other privilege which by law is made the right of this court to grant, shall give public notice of their intention by posting up advertisements of the same in three of the most public places in the county at least ten days previous to the sitting of the court at which time the petition is to be presented.

This was subsequently amended by requiring the publication of notices at least twice in the Deseret Neres.

Under this law the court granted rights to the use of the streams of Salt Lake County, and appointed 
commissioners to enforce them. When there was doubt as to the advisability of granting any petition the court took testimony, visited the region in question, and satisfied themselves as to the conditions, and either granted or refused the rights, as the facts justified.

We have here, then, at the very beginning of irrigation development in this country, the recognition of public ownership, the granting of rights by an executive board which was familiar with the facts, and the protection of the rights granted by the board making the grants. Irrigation law has not gone beyond this to-day, except in the matter of detail.

For twenty-eight years this was the only waterright law of the Territory. In I 880 it was superseded by a more elaborate statute which made county selectmen ex-officio water commissioners, with power to hear and determine all claims to water, settle disputes, and appoint commissioners to divide streams and distribute water. They were to issue certificates showing their findings on all claims submitted to them. The law also provided for the appointment of inter-county boards, with similar powers, where parties in different counties used water from the same source. This law did little more than state in detail the practice of the county courts under the old law. It did, however, abandon the principle contained in the former law: that the water of streams was public property, and that, in order to obtain rights to it, its owner, the public, must confirm the right. Under the new law, water 
was treated as belonging to nobody and open to appropriation without any legal formality. The county selectmen who composed the county court were not to hear petitions and grant rights, but were to hear and determine claims and settle disputes. This was held to be a judicial function and rendered the law void. It was, however, enforced in a number of counties in the Territory, where the irrigators presented their claims to the commissioners and received certificates of their rights. As this law is void, these certificates have no value, except to show that certain rights existed at the time of their issuance.

In 1897 Utah abandoned the distinctive features of its early irrigation law to copy those common to the arid States. This law provides that rights to the use of the unappropriated waters of the State may be acquired by appropriation, and that the appropriator must post and file a notice of the intended diversion. It further provides that persons who had acquired rights before the passage of the act "may file for record a declaration of their rights" ; but that the failure to file this declaration will not cause a forfeiture. The purpose of this law, here as elsewhere, was to provide a permanent record of all rights to water. Before its passage the entire flow of most of the streams of the State was appropriated, and as the recording of such rights is made optional, the law has proven of no practical use. Outside of this, it is of little value, because there is no restriction upon 
the claims which may be filed, and no examination or record to show whether the works described in the notices have been built. Similar records have been discussed in the preceding chapters.

This brief outline includes all the laws which have been enacted to govern the acquirement of water rights in Utah. So far as the methods of obtaining water rights are concerned, the State has gone backward from the position taken in 1852 . To-day the individual or company wishing to obtain a water right can nowhere find any complete record of the existing rights, there is no one to whom they can apply to find out whether there is water to be had, or who has authority to approve their taking water or to protect them in its use if they do so. The only method is to build works and take water until some one who is injured, or thinks he is, obtains an injunction from the courts and stops the new appropriation; or until a still later appropriator takes away their water-supply and compels them to appeal to the courts for protection against the later comer.

In I90I a law was passed for the appointment of water commissioners to divide the waters of streams among those entitled to their use " according to the prior rights of each," but the water commissioner is in no better situation than the prospective appropriator so far as finding out what are the "prior rights of each" irrigator.

The valley of the Jordan River in Utah is the birthplace of irrigation on this continent so far as 
English-speaking people are concerned, and it is there that titles to water ought to be most clearly defined and most stable. The irrigators are largely members of one faith and the foundation of their industrial organization is coöperation. The farmers of this valley have shown exceptional ability in the practical use of water and in the creation of regulations for its economical division from ditches, but an entirely different situation is disclosed when a study is made of the titles to water.

Utah Lake is the source of the Jordan River. The lake is fed by several streams of considerable size and by a number of smaller ones. The watersupply of the Jordan depends upon the flow of these tributary streams. Every diversion of a tributary affects the water-supply of the main river and has its influence on the stability of rights to this supply. In order, therefore, to protect these rights and to secure a complete and lasting settlement of titles, it is necessary that priorities on the main stream and on the tributaries should run consecutively, as they do now in the water divisions of Colorado and Wyoming. It is also necessary that there should be some authority to enforce these priorities throughout the entire drainage basin. Nothing of the kind exists. The rights on the Jordan have been adjudicated as though its watersupply was independent of everything else. The rights on each tributary are adjudicated without any respect to priorities below. Even sections of some of these tributary streams are adjudicated 
independently of other sections, and tributaries of tributaries have independent priorities. In I90 I the rights to the Jordan were adjudicated in a proceeding which lasted the longest time and is said to have cost the most money of any lawsuit ever waged in the State. Almost immediately after the adjudication, two new claims were filed, and if the work is carried out it will compel all the parties who have just been to such great expense in defending their rights to begin again this legal fight for existence.

On the Spanish Fork, there have been nine lawsuits over water titles in the past ten years; each suit has been brought for the purpose of quieting title. The trial of the first one occupied two years. Another one lasted five years, and in the ten years some of these titles have been quieted four times. On another tributary the litigation over water rights is reported to have cost $\$ 75,000$. Two trials in the lower court and one appeal to the supreme court have already been had in an attempt to settle the priorities of another tributary. In each case all the waters of the stream in controversy have been decreed to the appropriators along it, and in no case has any attention been paid to the natural relation which exists between the rights on these tributaries and on the main stream.

The growing use of water in Utah for power purposes is aggravating the evils connected with the settlement of titles to water for irrigation. In I 882 the county court of Salt Lake County conveyed five-sixths of the water of the Jordan River 
to five companies by deed, giving each company an undivided one-sixth interest in the stream. This action was giving title to water which came from streams flowing through six other counties, and the authority of the court of one county to make such grant, it would seem, should have been questioned. It was not, however, and these deeds for the time settled all controversies over the stream's ownership. Later on, new issues arose. A part of a right belonging to the City of Salt Lake was traded for water rights in smaller streams nearer the city. The river began to be used for power purposes. Out of these changing conditions came the litigation of r9or. The parties to this suit gathered evidence for two years. The trial itself lasted seventy-two days. The decision of the court ignored every previous settlement of water titles, and paid no attention to the deeds of the county court. So far as the outcome of the litigation was concerned, there might as well have never been an irrigation statute in Utah. The decision has been approved by the supreme court, but it cannot end the controversies over water rights on this stream, because, sooner or later, the relation of the parties to this suit to the appropriators of the tributaries must be defined. Further litigation is inevitable, and when it comes it cannot help overthrowing everything which has gone before.

\section{Nature of Water Rights}

The recent laws of Utah make water personal property and permit the transfer of water rights 
like other property. They may be separated from the land where acquired and from the ditch where diverted, with the exception that where a water right has been used on a piece of ground, the sale of the land conveys the water right unless it is specifically reserved. This is a complete reversal of the early policy of the Mormons, which held that water rights should be inseparable from land.

While the doctrine of priority is recognized to a certain extent, it is modified by dividing rights into classes. The law of I 880 defined two classes, primary and secondary rights. Primary rights include all rights acquired up to the time when the sum of the rights equals the average flow of the stream at low-water stage. Secondary rights are rights acquired to any supply in excess of the average low-water flow, and are subject to the complete enjoyment of primary rights. Whenever there is not water enough for all primary rights, the flow of the stream is divided among them pro rata. When there is more than enough for the primary rights, but not enough for all secondary rights, the excess over the primary rights is divided among the secondary rights pro rata. The law carries the classification no farther, but numerous court decrees have divided the rights into more than two classes. In adjudicating the rights on the upper section of the Provo River in I 899 the court divided the rights into ten classes, on the same basis as the primary and secondary rights defined in the law. This classification of 
rights has all the advantages of the law of priority adopted in the other States of the West, and none of its disadvantages. A farmer who has made improvements and used water to reclaim his homestead should be protected from the encroachments of later comers; but it is equally unjust to allow him in seasons of extraordinary drouth to use water lavishly while his neighbors' crops and orchards and trees are dying.

A further modification of the general practice of the arid region was contained in the law of 1880 . Section 8 of that law provided that

a right to the use of water may be measured by fractional parts of the whole supply, or by fractional parts with a limitation as to periods of time when used, or intended to be used; or it may be measured by cubic inches, with a limitation specifying the depth, width, and declination of the water at the point of measurement, and if necessary, with further limitations as to the periods of time when used, or intended to be used.

Some of the certificates on record in Morgan County represent rights to water for a given acreage, some to portions of the streams, and still others to the whole of some stream for a specified portion of the time. The courts have followed the same system in rendering decrees for water rights. In the case of Center Creek Irrigation Co. $v$. Thomas, in Wasatch County, the court held that Thomas had a right to " a stream of water flowing Ioo cubic feet per minute for forty-eight hours every twenty days." In the adjudication of the rights to the lower Provo River the court divided 
the stream into parts, giving the various canals fixed portions of the stream, the portions varying at different stages of the river. In adjudicating rights to water from Jordan River, the court decreed to some ditches definite volumes, flowing constantly, and to others portions of what is left after those having rights to fixed volumes have been supplied.

The granting of rights to a continuous flow of a fixed volume of water from streams and canals has been one of the most fruitful sources of trouble in the irrigated West. An early settler uses a large quantity of water during flood time, but this is only for a brief period. During the remainder of the season only a small fraction of this volume is required. After others have come and have used water from the same source, trouble arises and an adjudication takes place. The first settler shows that his ditch carried a certain volume and that he had used that much water, and he receives a decree for that volume, flowing continuously. Years after, more enterprising or more industrious farmers come and begin a better system of farming, using water later in the season, without interference with the use of the early settler, for he has never used water at that time of the year. This may go on for years before the early appropriator awakes to the fact that he has been decreed a right to that water and that he can enforce that right against those who are making such profit from its use. He therefore changes his style of farming, or sells this surplus, which he has never 
used and to which he has no moral right, to reclaim new lands, or forces those who have used the water for years to pay him tribute. The Utah practice is much better. The settler who has used water only during flood season is given a decree for water from April I to July I, or about that period, and those who have later made use of the water during the whole season are given decrees to that effect and are safe from any enlarged use under the early right, or any blackmail by its holder. The following table, giving the result of an early determination of the rights to water from Big Cottonwood Creek, shows the workings of this system :-

Division of the Water of Big Cottonwood CreeK ${ }^{1}$

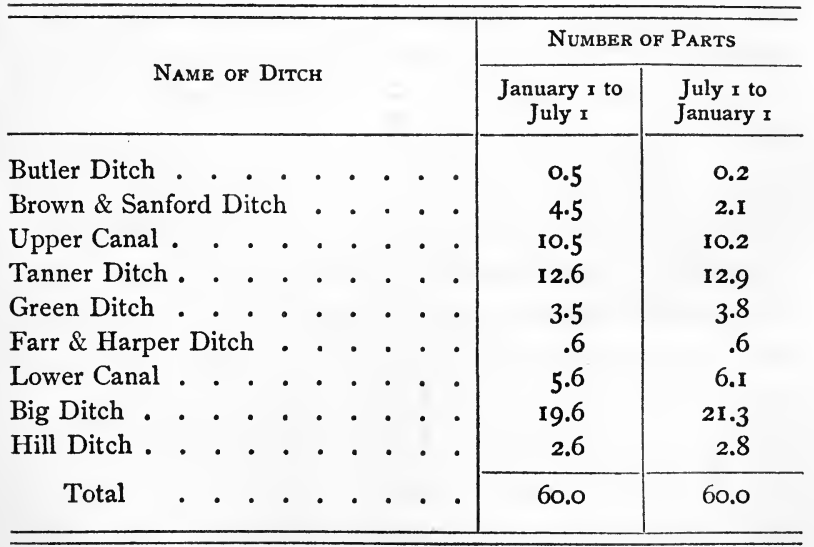

1 United States Department of Agriculture, Office of Experiment Stations, Bulletin 86, p. 198. 
It will be seen that the first two ditches receive larger portions of the stream during the first half of the year than during the latter half, while the last three receive larger portions during the latter half.

The two features just described - the divisions of rights into classes, and the granting of rights to parts of the supply or for limited periods - are the chief points of difference between the Utah law and that of the other arid States. In both these provisions Utah is in advance of her sister States.

\section{Controversies over Water Rights}

Public records and court proceedings give no index to the controversies which have arisen over water rights in Utah. Until the last few years such matters have usually been settled by agreement, with the church authorities as arbiters, and this method is still employed to a large extent. Even where appeal to the courts is made, it is often for the purpose of giving the force of a court decree to an agreement reached through the influence of the church. As a result of this practice, the impossible decrees, which are so common in other States, are rare in Utah. The decrees on the Jordan River, except in a few minor details, merely give judicial sanction to the practice of twenty years in dividing the waters of that stream. The decree settling rights on the lower Provo River was only a slight modification of an agreement drawn 
up by the parties using the water. The same thing is true of other decrees throughout the State. The waters of American Fork River are still divided in accordance with a decision of a church court - the high council of Utah stake of Zion - made in 1879.

Another method of settling the rights to a stream which is peculiar to Utah is known as the incorporation of the stream. All parties having used water from the stream come to an agreement as to their rights, usually on an acreage basis ; then form a corporation, and issue to each farmer or to each ditch company stock in proportion to their rights. The stream is then controlled by the water master, who is elected by the members of the corporation.

The right of such a corporation to control a stream will, of course, depend upon bringing into the organization all parties having rights to the stream, and is practicable only on the smaller streams.

\section{Canal Organization and Management}

With one or two exceptions, the canals of Utah are coöperative, and the large majority of canal companies are organized under the general incorporation laws of the State. This has come about as the result of long experience and unsuccessful experiment in other forms of organization. In Salt Lake County, which is the centre from which the people of Utah have gone out to colonize their own State and the neighboring states, every form of organization has been undertaken, only to be aban- 
doned for the corporation formed of those using the water.

In 1854 and in 1862 stock companies to build canals and sell water were chartered by the Territorial legislature, but neither company progressed far enough to do any construction work.

An irrigation district law was passed in 1865 . This law provided for the organization of districts for the construction of irrigation works, and for the levying of taxes to cover the cost of construction. It was made optional with the organizers whether the tax should be upon all taxable property of the district or only upon the lands to be benefited. The law made no provision for issuing bonds or borrowing money, and therefore a district had no advantages over an ordinary incorporation of those interested, except that a few people could be forced into the district organization against their wills, since a two-thirds vote in favor of the organization of the district and of the tax made the tax a law in the district. At one time or another practically all the irrigable land in Salt Lake County has been included in irrigation districts, but all have been abandoned. A number of districts have been organized in other parts of the State, a few of which have survived. Where this is true the district canals are managed in the same way as the corporation canals. The district law has been repealed, having had no appreciable results.

County construction was also tried in Salt Lake County, but produced little result. Public money 
was spent on most of the large canals from Jordan River, but after a few years this policy was abandoned, and the works which had been begun were turned over to the canal companies, which completed them and now own them.

The farmers in Utah have not, as a rule, favored the organization of stock companies for the construction of ditches. Usually they club together, furnish the money and labor needed to build the ditch, and divide the water it carries into shares which agree with the amount of work or money supplied by each shareholder. Even where they are organized as stock companies, and stock is sold to provide money or pay for work done on the canal, the ditch companies are not managed as are corporations organized for other purposes. Instead of charging for the water furnished and applying the rentals received to pay the maintenance charges and dividends on the stock, no charge whatever is made for water. The stock entitles its owner to a portion of the water in the canal, which can be used on any land which can be reached by the canal, and may be sold or rented if the owner does not need it. There are no restrictions as to the area upon which this water may be used, its owner using his judgment in that matter. The expenses of management and maintenance of the canal are met by assessments on the stock, most of which are paid in work. A law of the State allows these corporations to sell at auction the stock on which the assessments are not paid, 
and provides for the buying in of stock when the bids are not high enough to pay the amount of the delinquency.

Under this plan, shares of stock in a ditch are looked upon and treated as shares in the water which fills the ditch. The financial results are sometimes perplexing to stockholders, as one example will show. The farmers who began the D. $\& W$. canal were not able to complete it. To raise money for this purpose they sold some stock to a banker not familiar with irrigation methods. When the canal was completed, the banker was assessed on his stock to help pay running expenses. $\mathrm{He}$ received no dividends because there was no charge for water, and hence no revenue from the canal. His stock entitled him to a part of the water of the canal, but he had no land on which to use it. He could not sell it to the farmers, because they were able to take his share along with their own. For several years he was assessed on his stock to help pay the running expenses of the ditch, from which he derived no revenue whatever. This could not continue forever, and the investment was too large to be sacrificed. The stock at that time, however, had no selling value, and unless some change could be made in the method of operating the ditch, the investment would prove a total loss. The method taken to improve the situation was as ingenious as it was successful. $\mathrm{He}$ loaned his stock to one of the farmers under the ditch for a single year. This farmer was the envy 
of all his neighbors; he had water whenever he needed it in unlimited abundance. The next year other farmers wished to share in their neighbor's opulence. When the banker refused to lend his stock, they agreed to rent it. In a few years it was renting for enough to pay interest, and subsequently was sold for enough to repay the investment.

A number of canals are controlled by municipal corporations. In such cases they are under the management of the town councils, which levy assessments to cover the expenses of maintenance and management and appoint water masters to distribute the water. In some such cases the water rights are attached to the land; in others individuals own rights, and can sell or rent them just as under corporate canals.

Water is distributed from canals by the superintendent or water master elected by the stockholders for that purpose. Under canals owned by stock companies, each share represents a definite portion of whatever water the canal supplies. Each lateral from such a canal carries the water belonging to several stockholders, and the quantity of water turned into each lateral depends on the number of shares which are represented in that lateral. In other parts of the State the canal superintendents divide the water into "irrigating streams" which carry the volume which one man can conveniently use, and vary in volume according to the judgment of the superintendent. (See 
p. III.) Where rights are measured by the area irrigated, the volume turned into each lateral is governed by the number of acres to be served by the laterals.

After water is turned into a lateral it passes from the control of the canal officials. Those irrigating from a lateral elect a water master who distributes the supply according to a schedule made out by the water users. If the stream is no larger than can be used to advantage by one man it is used in turn by the farmers, the length of time which each uses the stream depending on his interest in the ditch. If more than one "irrigating stream " is carried by a lateral, the water is divided into streams, which are used in turn as just described. At the beginning of the season a schedule is made out showing just when each user is entitled to take the stream, and how long he may use it. As a rule it is not necessary for the water master to attend to the distribution, each farmer taking the water when his turn comes, and keeping it until the one next entitled to it comes and takes it.

In times of extreme drouth the same system of rotation is used in distributing water from the larger canals to the laterals. When the volume of water to which each lateral is entitled is so small as to be of little use, several laterals enter into an agreement, and take the water to which all are entitled in turn. This gives the water to each farmer less often, but gives him a good working stream. This system of rotation might, in dry 


\section{IRRIGATION IN UTAH}

seasons, be adopted with advantage in dividing the water from a river among canals. At times during the season of I9OI the large canals from Jordan River, each of which waters several thousand acres, were receiving but sixteen cubic feet per second each. This would hardly flow to the end of a long canal if none was used, so that the whole flow of the river was practically wasted. If the whole supply of eighty cubic feet per second which went to the five large canals could have been taken by each canal in turn, a much better use of the water could have been made.

\section{The State Engineer}

The office of State engineer was created in I 897, but the powers and funds of the office were so limited that the engineer could do little. $\mathrm{He}$ was required to examine reservoir sites for the State board of land commissioners, and keep a record of such stream measurements and other facts of interest as came to his notice. His approval was necessary for all dams over ten feet high constructed in the State.

An attempt was made in I90 I to adopt a comprehensive system of water laws for the State. This attempt failed, but a part of the law proposed was enacted. This enlarged the duties of the State engineer, but the appropriation necessary to the carrying out of the new duties was not made, leaving the engineer with little 
power. The law requires the engineer to measure the streams of the State, beginning on those most used for irrigation. $\mathrm{He}$ is to give notice of the time when measurements are to be made on any stream, and at the appointed time measure the flow of the stream, the diversions therefrom, the area irrigated, and the area capable of irrigation. $\mathrm{He}$ is also to make maps showing the streams and the lands irrigated and capable of irrigation from them, copies of which are to be filed with the county recorders of the counties in which the streams are situated. The law as proposed contained a provision for the adjudication of all rights to the streams of the State, and these measurements were to be the basis for the settlement of rights. As the provision for adjudication was not passed, and no appropriation was made to cover the expense of the measurements, this part of the law has been inoperative. The same law provided for the division of the counties of the State into water districts and for the appointment by the county commissioners of water commissioners to distribute the waters of the county. The State engineer is given "general supervision" of these water commissioners, and is required to instruct them as to the manner in which measurements of water shall be made. The water commissioners are required to report to the engineer as often as the engineer deems necessary, and their reports are to contain such information as he may require. The relation of the engineer to the water commis- 


\section{IRRIGATION IN UTAH}

sioners is rather loosely defined, but the present State engineer has recognized the necessity for central control and has exercised it to the great benefit of irrigation in a number of instances.

\section{Future Development}

With the exception of Bear River, the late watersupply of the Salt Lake basin has been used in irrigation for many years. In fact, there are few streams on which there is not every year a scarcity and an injury of some fields by drouth. Further expansion is, therefore, restricted to storage, the development of underground waters, the drainage of lands which have been flooded by irrigation above, and a better distribution and use of water by farmers.

The greatest extension of irrigation is to come from storage. This, on a number of rivers, has already assumed great economic importance. The largest and most valuable reservoir is Utah Lake, which is used to regulate the flow of the Jordan River. Improvements are now being made at its outlet which will provide for more perfect control in the future. It will also make it possible to draw off more water in times of scarcity and thus materially increase the available water-supply of the ditches around Salt Lake City. The completion of these improvements will permit all the surplus water of the streams flowing into this lake to be stored, at least all that empties into the lake in 


\section{IRRIGATION INSTITUTIONS}

years of average snowfall; and if the extension of the irrigated territory along these tributaries continues, there will not be enough water come down to fill the lake. The outlook is, therefore, that the canals already built in the valley of the Jordan cover all the land they can be made to serve. The extension of the irrigated territory in this part of the State depends more on effective dis(u) of the water-supply and stopping of ce from seepage than by increasing the watersupply. On the Sevier in the south and on the Weber, Ogden, Bear, and Logan rivers in the north, storage has great possibilities. Much water is lost from each of these streams during the early part of the year, which is needed later on. The profits of crops requiring late water are so much greater than from those having but a short growing season that it is probable that little new land will be reclaimed by the use of this stored water. Future development will be along the line of a more intensive culture.

The soil and climate of all these valleys is well suited to market gardening and fruit growing, and these have become important industries. Two beet-sugar factories are already in successful operation in Utah, and Ogden has become a great centre for the canning of fruits and vegetables. The fluctuating water-supply of unregulated streams is not a safe reliance in the growing of high-priced products. The few reservoirs which have been built have proven exceedingly profit- 
able to their owners, and of greater value to the public. The East Canyon Creek reservoir, which cost $\$ 85,000$, paid its owners $\$ 50,000$ in r 90 I. In addition it lifted a load of anxiety and dread from irrigators, who now know that the crops planted will be brought to maturity, - something they could never be sure of when they relied entirely on the stream.

In addition to this it is estimated that this reser voir has not only permitted the growing of high priced products, but has added 50 per cent to thic productive capacity of the land.

To those not familiar with Utah, it may seem an absurd statement to say that outside of the valleys of Grand and Green rivers drainage stands next to reservoirs as a means of increasing the cultivated area. The ditches of Jordan and Logan valleys lose from 20 to 50 per cent of their water-supply by seepage. The high-line ditches run through a coarse, gravelly soil along the steep slopes at the base of the mountains, where all the conditions favor an excessive loss through their sides and bottom. This water finds its way readily to the low-lying lands of the valley, where it creates bogs and marshes. To the excess of water is added an excess of alkali washed out of the irrigated lands above. Both can be removed by drainage; and when this is done, some of the most valuable lands in the State, both as regards their fertility and location, will be again restored to cultivation. 
The general construction of reservoirs is being delayed by the absence of adequate public control over streams. Many of these works must be built up in the mountains and the water must be carried down in the natural streams to the places of use. To do this, it will have to pass the head-gates of ditches having no interest in the stored water, but whose owners will be disposed to take it unless the head-gates are regulated by some public and disinterested authority. The water of East Canyon Creek reservoir, before referred to, has to be turned into East Canyon Creek and carried down this stream into the Weber, and then the stored water separated from the natural flow of this river. Unless the head-gates of intermediate ditches can be closed while the reservoir is being emptied, they will take the entire supply and none will reach the canal of its owners. Last year the State engineer was called in to act as an arbiter to arrange for the closing of these gates, but it was entirely optional with their owners as to whether or not they would follow his recommendations. They did so, but the neighborly feeling which this evidenced cannot always be relied upon, and it is unfair to a public official and a menace to development, to leave so important a matter in this condition.

One of the largest and costliest canal systems in the arid West is in northern Utah. It diverts the water of Bear River on to the elevated plain north of Salt Lake. It is the only irrigation system 
in Utah built by outside capital and the only one where the farmers have no ownership in the canal. From a financial standpoint it has thus far been an unfortunate failure; unfortunate, because it has been worth far more to the State than it cost, and its builders should have been rewarded for their energy and enterprise. The losses to its builders are another illustration of misfit land laws. The land it was to irrigate was filed upon in part by speculators and in part by farmers who were prejudiced against outside investments and opposed to contract water rights. These farmers refused to become customers of the canal, and lack of income caused its sale for less than onetenth of what it cost. Recently it has passed into the hands of local owners who are members of the Mormon church, and who, from their understanding of local conditions and acquaintance with Utah farmers, will doubtless secure the rapid development of the country it is to serve.

In the eastern part of the State there is more water than can be used. The Grand and Green are large rivers, but they traverse a mountainous country where there is little agricultural land and where the obstacles to diversion are serious. To irrigate the valleys along these rivers will require large and costly works which will hardly be built by private enterprise. These streams furnish an appropriate field for the expenditure of public funds, and doubtless some of the works to be built under the laws passed by the last Congress will be 


\section{IRRIGATION INSTITUTIONS}

located here. In the western part of the State, notably along the Sevier, there are large tracts of level land exceedingly fertile and having an attractive climate. For these there is no water unless it can be secured from underground sources and from the storage of the comparatively small volume of water not now utilized by irrigators. 


\section{CHAPTER XI}

\section{IRRIGATION IN WYOMING}

ReCENTLy two men were talking about the importance of irrigation in the different arid States. One said that Colorado and California were the leading States, and that in these States about every question had been litigated and settled, so that irrigators knew what they were doing. The other asked why he did not include Wyoming, and was told that irrigation had not made much progress in Wyoming, that an investigation had shown that only two water-right cases had ever been decided by the State supreme court. In the mind of the speaker, litigation went with irrigation, as fever with malaria, and a State with only two lawsuits was not worth notice.

Nevertheless, over nine thousand irrigators are taking water from over six hundred streams with a certainty as to their rights and an absence of friction in the protection of these rights, which is in such striking contrast with the situation in surrounding States as to make the methods by which this result was accomplished of unusual interest.

The first ditches built in Wyoming were along the Overland Trail and in the vicinity of the military posts. The oldest of which there is any 
official record was built in 1857 , and several were constructed in the early sixties. The first irrigation law was passed in 1875 . It gave parties owning or claiming lands along streams the right to take water for irrigation and provided that in times of scarcity the county commissioners should appoint three water commissioners to divide the supply among those having rights therein. No provision was made for recording claims, nor was priority of use recognized as giving a better right. In the division of water all users stood on an equal footing. The rights of the last ditch-builder were not inferior to those of the first. The three water commissioners were authorized to arrange for rotation in use, and to give to each user all the water he needed part of the time, rather than less than he needed all of the time. In many respects it was an admirable beginning, but it had one weakness, which was fatal. It did not fix the salary of the water commissioners or make provision for paying them anything. The office, therefore, was not a desirable one and soon fell into disrepute. In its influence on future development the law was important because of its protection of riparian rights, and because it made the ownership of land rather than the construction of ditches the foundation of the water right.

For eleven years there was no further irrigation legislation, but in 1886 the State legislature passed what was practically a copy of the Colorado law of I88I. This law made radical changes in methods, 
and an equally radical departure from the original Wyoming law. Under the law of 1875 the ownership or control of land was the foundation of a right to water. Under the law of 1886 the construction of ditches was made the foundation of this right, although there was a requirement, not found in the Colorado law, that the acreage of land irrigated should be made a part of the proof of appropriation. The method of adjudication was the same as in Colorado, and the doctrine of priority of appropriation giving a better right was also adopted. The law also provided for recording the claims of existing ditches, and for a record of - intended appropriations. The claims for existing ditches were to be filed with the clerk of the district court, and those for future appropriation, with the county clerk. A further record of existing works was provided for by requiring the county surveyor of each county to measure all ditches in his territory and issue certificates for their capacity, which were to be recorded.

The law soon became unpopular. The claims made were indefinite and usually for extravagant volumes; the surveyors' charges were excessive, and oftentimes their measurements were fraudulent, certificates being made out without even visiting the ditches. After all the fees had been paid users had no protection in their rights. No practical results were reached. Before the law was passed the three water commissioners provided for in the original act could divide any stream in times of 


\section{IRRIGATION INSTITUTIONS}

scarcity, but after its passage there could be no such public division of water until rights had been adjudicated by the district court. The admirable provisions taken from the Colorado law, for the employment of commissioners to divide streams in times of scarcity, could not be put into operation until the priorities of appropriators had been established.

Two years later the law was modified and greatly improved. The certificates of county surveyors were abolished, the office of Territorial engineer was created, limitations were placed on the speculative claims of ditch-builders, and the charging of a bonus or royalty for water forbidden. Nevertheless, the law remained in disfavor. In the five years of its existence, only six streams were adjudicated. The results of these adjudications were so unsatisfactory that irrigators preferred to lose their crops rather than to attempt to secure a settlement of rights by this method. The first decree under the Territorial statute adjudicated rights on Bear Creek. In this adjudication only six of the forty-two recorded appropriations were determined. On another stream, 485 cubic feet of water per second of time was decreed to be appropriated, although the average flow of the stream was less than Io cubic feet per second. Apparently each appropriator was given all he claimed, regardless of the actual duty of water, or of the necessities of beneficial use. One appropriator was given $4 \frac{1}{2}$ cubic feet per second for 100 acres. The next appro- 


\section{IRRIGATION IN WYOMING}

priator was given 3 cubic feet per second for 100 acres. Under another ditch the same appropriator was given 2 cubic feet per second for 30 acres. The first appropriation on the stream was 12 cubic feet per second, which was more than the average flow, and legally left nothing for the sixty other appropriators. In the adjudication of Horse Creek, one of the six streams dealt with, 6 cubic feet per second was allowed for the irrigation of 9 acres of land. The right was to a continuous flow for the entire year, not omitting Sundays. This would cover the land to a depth of over 450 feet. In the same decree 2000 acres received only 5 cubic feet per second. Such proceedings were prevented from being farcical only by their disastrous effect on the public welfare. In addition to the unsatisfactory outcome, these adjudications had proven enormously expensive, both to the State and to irrigators. Furthermore, the law was not a working code. The water districts created by the legislature followed county boundaries rather than drainage lines, and some streams were cut into two or three sections. There was no single place of record for claims and adjudicated rights to water. The authority of the State engineer was nominal, not real. He had no oversight of the building of canals nor any influence in the adjudication of rights. Five different members of the Territorial government, elected to perform other duties, and with little or no knowledge of irrigation, had to deal with water-right questions before they reached his office. The 
result was a chaos which all recognized should be brought to an end.

When Wyoming became a State these accumulated water-right complications made irrigation one of the most important questions to be considered in the constitutional convention. It is fortunate that among the members of this body were a number of men who were unusually well informed on the subject, and who sought not simply to correct the mistakes of the past, but to create a system suited to the needs of the future. The sections of the constitution which dealt with irrigation declared broadly the doctrine that all natural streams, springs, lakes, or other collections of still water, within the borders of the State, were the property of the State, and that they should forever remain under public ownership and control. It provided for a special tribunal to administer this property, composed of a State engineer and four superintendents of water divisions which were bounded by drainage lines. To carry these provisions into effect two entirely different things had to be done. One was to settle the accumulated Territorial rights, the other to provide a system which would prevent such accumulation in the future.

Familiarity with the results of court adjudication in a number of States had led to the conviction that this method of establishing titles to water was needlessly cumbersome and expensive. There seemed to be no reason why the facts showing the actual use of water could not be presented in a 
much simpler manner. To prevent delay and controversies in the future, it was determined to require all parties proposing to use the public watersupply to secure permits from the State, and to have the conditions of these permits as definite as the regulations which govern filing on public land.

The most urgent problem was the settlement of the accumulated Territorial rights. There were over 3000 of these. On many streams there was a shortage of water, and controversies of long standing. In order to facilitate a prompt settlement of these matters the law provided that all of the county records should be transferred to the State engineer's office, which was thereafter to be the office of record for all appropriations.

The severest test of the law came immediately after its enactment, in the settlement of Territorial rights on streams where irrigators were already at war with each other. On these streams the board of control faced a water-right situation as perplexing and chaotic as that of California. In each county book after book had been filled with notices of appropriations. The fever of speculative filings had run its course and hundreds of claims had been recorded by parties who had done nothing more than file the statement. The name of one individual was found in the water-right records of every county in the State, although he built only one ditch and that in the county where he lived. The sifting of the chaff from the wheat in these extravagant claims was rendered more difficult be- 
cause the parties making them objected to the rigid supervision which the State law inaugurated. They insisted that the rights they had acquired were vested, and that it was not within the power of a State tribunal to interfere with the exercise of privileges granted by the Territorial laws. An effort was made to discredit the board before its labors began, by an appeal to the prejudice and selfishness of the older appropriators.

The board began its struggle with the Territorial chaos on a river where controversies were acute and appropriators were at war. For several years there had been a shortage during the latter part of the irrigation season. With all the water in use, it was impossible to give any appropriator more than enough to meet his necessities without robbing later appropriators. To recognize any right to water in excess of actual use meant inevitably an injustice to some other appropriator. Because of its results and because of a belief in the principles they were supporting, the board refused to consider claims to water not based on use as having any validity. In order that irrigators might understand this, it adopted and published the following as the principles which would govern its decisions in all water-right determinations :-

Ist. That to constitute a valid appropriation the water must have been applied to a beneficial use, and in the case of appropriation for irrigation the water must have actually been applied to the land.

2nd. That the amount of the appropriation is governed 


\section{IRRIGATION IN WYOMING}

by the volume used and by the requirements of this use. In the case of appropriations for irrigation, by the needs of the land reclaimed.

3rd. Where reasonable diligence is shown in the construction of diverting works and utilizing water, the appropriation dates from the beginning of work on the ditch, the survey to be considered as a part of such work. Where reasonable diligence is not shown, the appropriation to date from the utilization of the water.

4th. Priority of appropriation to give priority of right except in the case of appropriations made between 1888 and 1891, during which time the law gave appropriations for domestic use a preferred priority.

5 th. The present law restricts appropriations for irrigation to one cubic foot per second for each seventy acres irrigated. While this does not apply to lands reclaimed before its enactment, no appropriation for a larger amount will be recognized, because in all cases so far considered this volume has appeared to be ample.

In order to apply these principles properly, the board must know why and where water is being used, and be able to show all those affected by its decisions that the information on which they were based was accurate and reliable. The problem was not simply to satisfy its members that its decisions were lawful and right, but to convince appropriators that its policy was both just and wise. This required, first of all, a careful examination of the physical conditions along the stream. Each ditch diverting water was surveyed and its capacity measured. The area of the land it irrigated was determined, the flow of the river was gauged from time to time during the season, and records kept 


\section{IRRIGATION INSTITUTIONS}

of the ditches which diverted this water. When these field investigations were completed, maps and tables were prepared which showed the location and size of the ditches, the areas of land irrigated, and the measured flow of the stream. Equipped with this information, the board was prepared to pass intelligently on the claims of appropriators. The preparation and submission of their proofs was made simple by use of blank forms which were in part copied after the desert land proofs used in the United States land offices, which enabled appropriators to state definitely, but briefly, the date when the ditch was built, and the successive dates when the land it watered was irrigated. Many were able to prepare their proofs without any advice or assistance and without incurring any expense, as the surveys of ditches, maps of irrigated land, and gauging of water-supply were all paid for by the State. Later on, when the State law was better understood, it was rare that these proofs contained either inaccuracies or misstatements, but at the outset some of the proofs submitted were curiosities. As it was known that the amount of the appropriation would be fixed by the acreage of land which had been irrigated, some of the claimants with expansive ideas included in their descriptions lands which were many miles away from and hundreds of feet above their ditches. Without the preliminary survey some of these proofs might have been accepted, but with the official map before it the 
board always noted the discrepancies between the sworn statement and the actual situation. It required tact, firmness, and patience to have these attempts to secure excessive amounts of water rectified and prevent a rebellion against the rigid adherence to facts, which was in such striking contrast to the slipshod methods that had hitherto prevailed. It was made manifest, however, that the board always stood ready to correct its maps or measurements if they were shown to be in error, but until this was shown no variation between them and the proofs would be overlooked. A few test surveys were made, but the official maps proved to be correct. Of late years their accuracy is rarely questioned.

When the agreement between the proof and the survey was finally secured, a table was made which gave the acreage irrigated by each appropriator and the amount of water required under an assumed minimum duty of one cubic foot per second for each 70 acres of land reclaimed.

After these proofs of appropriation were submitted, all interested parties were given an opportunity to inspect them and contest any statement or claim believed to be erroneous. There was a large attendance at the first inspection, and a general disposition to oppose the board's ruling that the volume of an appropriation should be determined by the acres irrigated rather than by what was claimed. But when the water required for the land already irrigated was compared 
with the total flow of the stream, and these with the table of recorded claims, there was a complete reversal of sentiment. There were in all I32 ditches. If each appropriator should receive what he claimed, the first five would have a right to the entire supply after midsummer, and the first six or seven would have a right to the entire supply at any time. This would leave the owners of the 126 ditches dependent upon the generosity of the favored few having the prior rights. It was manifest, on the other hand, that if the board's ruling was maintained, no actual user of water would have his supply lessened. Every ditch could be filled during part of the season, and, with economy, nearly all would have an ample supply throughout the entire season. The policy of the board was accepted and the harmonious and satisfactory settlement of rights in the first adjudication has been followed by ten years of similar results. Beginning in opposition to preconceived ideas, the board has in the intervening years succeeded in defining and establishing almost 4000 Territorial rights, with remarkably few contests or protests against its decisions. The records of the last determination of Territorial rights made by the board of control show that it included 236 appropriators, some of whose rights dated back twenty years and amounted in the aggregate to 500 cubic feet per second. All of the rights to a river and its tributaries were determined in this one proceeding, without friction between ap- 
propriators, and with a total expense to each of $\$ I .75$ in fees for the issuance and recording of each certificate of appropriation. The State paid for the surveys, but it has been immensely benefited by its expenditure. By dealing with the appropriation of water as a public and not a private matter, it has promoted development, established peace where discord formerly prevailed, and added to both the selling and taxable value of irrigated land. With rights based upon the facts and clearly defined the water commissioner has a reliable guide for his action. $\mathrm{He}$ can divide a stream in accordance with his table of appropriations.

The freedom from litigation in Wyoming is due in large part to the preliminary surveys and measurements of the State engineer's office, and to making the facts thus gathered the basis of the rights recognized.

A number of cases were transferred from the courts to the board of control. Among these was one which raised a question of fundamental importance, namely, whether more water could be appropriated under the Territorial laws than had been used. Before rendering a decision the board measured the stream and the ditches and surveyed the lands irrigated. When measured, the stream carried 5.25 cubic feet per second. The first appropriator claimed 52 cubic feet per second, almost ten times the total supply. Another claimant testified to the irrigation of 60 acres, but claimed 


\section{IRRIGATION INSTITUTIONS}

to have appropriated water for I50 acres. This proof contained the following statement:-

Claimant appropriated water sufficient for 150 acres of land and now claims water for said land. He does not use said water, but if farming becomes more profitable, he may desire to cultivate his land and his appropriation was made to cover all said land.

The map which accompanied this proof showed that only 100 acres of the I50 could be irrigated from the ditch then built, the remainder being on the opposite side of the stream; so that, if the appropriation had been made, it was made without either beneficial use or means of diversion. The order of the board fixed the appropriation at the amount of water needed for 60 acres. Accompanying that decision was the following statement :

Proof states that water for 150 acres has been appropriated. If this were true, how was it appropriated? It was not diverted; it was not used; and the question arises, does the belief of an appropriator that he will at some future time require a certain volume of water constitute an appropriation of that volume? The claimant states that he may wish to use the water when farming becomes more profitable. Meantime, others have used all the water of the stream without waiting for the larger returns. In all, 435 acres of land is now irrigated. On this land, six farmers, with their families, have their homes. The land now cultivated requires more water than the stream supplies, and the users under later rights have less than they need. The proofs of the appropriators show this, and the engineer's gauging of the stream in July confirms it, its discharge being 5.25 cubic feet per second, while the needs of the land now irrigated, based on I cubic 
foot per second for each 70 acres, is 6.2I cubic feet per second. If, then, the appropriation claimed is allowed, the water for the additional 90 of the I 50 acres will be taken from a present user and given to a proposed user, to be held as a speculative commodity until it becomes valuable enough for him to use or to be sold to those now using it.

The report of the State engineer for 1900 says that 94I 8 parties are appropriators of water under the Wyoming law. Thirty-six hundred and fortynine of these acquired their rights under the Territorial law, the remainder under the State law. Nearly all of the Territorial rights have been established by the board of control. These rights were acquired under a diversity of conditions and under beliefs regarding the nature of appropriation which differed widely from the principles which have governed the board's action. Nevertheless, the board's action has resulted in a final settlement of these titles in nearly every instance. There has been no more discontent over its rulings than accompanies the determination of an equal number of land filings. The contrast between the stability of water rights in Wyoming and the uncertainty, the litigation, and the excessive appropriations which prevail in the surrounding States, shows that the existence of better conditions in Wyoming is not a matter of accident, but is due to the operation of a more effective plan.

In one of its early rulings the board refused to recognize the transfer of rights from the place where acquired to other lands. This refusal was 
based on the fact that there was no statute conferring such right or defining a procedure which would give notice to other appropriators who might be injured by the transfer, or furnish a reliable guide to the water commissioners. This ruling has been frequently objected to and is now being contested in the courts. The board has had the following additional reasons for refusing to recognize these transfers: The party seeking to make such transfer has never been willing to surrender the right to water for the land described in the original certificate or to accept a right for an equal number of acres elsewhere. In every case the real object of the transfer was to establish a right to more water. In every case the changes proposed would injure other appropriators and increase the labor and difficulties of the State irrigation authorities.

A case now in the courts fairly illustrates the character of all these transfers. The first appropriator on the stream received a certificate of appropriation from the board of control giving him a right to water for the irrigation of 700 acres of land. The location of the land was described by legal subdivisions and the maximum amount of water allowed for this land was I cubic foot per second for each 70 acres. On the stream were three appropriators. There was water enough for two of them but not enough for all three. In order to increase his water-supply the third appropriator bought from the first his appropriation for onehalf the time. The construction placed on the 262 
appropriation in this transfer was that the right was to ro cubic feet of water per second, regardless of the necessities of the land. In selling the right to this amount of water for one-half of the time, the first appropriator did not abandon any of the land described in his original statement. On the contrary, he extended the ditch so as to include additional lands. The party who bought the water for half the time did not, in the transfer or elsewhere, designate the use to which he intended to put this water, nor the land to which it was to be applied if used for irrigation. The practical result of the sale was to more than double the demand made on the stream by the first appropriation, to destroy the rights of the second appropriator, and to give them to the third appropriator. The board of control refused to recognize the sale, and litigation to compel it to do so followed. The decision of the lower court held that the sale was valid, and an appeal was taken to the supreme court, where the matter now rests. In the decision of the lower court it was held, -

That the right to the use of water is a property right which belongs to the appropriator and can be sold and disposed of as other property;

That water rights acquired for irrigation prior to the passage of the State law may be used on any land whatsoever at the will of the appropriator;

That an appropriation of water up to the maximum amount allowed by the law constitutes a right to a continuous flow of water up to that amount, 
regardless of the necessities of the land for which the appropriation was acquired.

All these rights were acquired during the Territorial period and before the passage of the law of I 886. At that time rights were wholly based on the necessities of the land, and the decision of the court could not be based on the statutes of Wyoming, but on the decisions of other courts based on entirely different statutes. It is not believed, therefore, that it will be sustained by the supreme court. If it is, water rights acquired during the Territorial period will become personal property. The water of the public streams will become a form of merchandise, and limitations to beneficial use a mere legal fiction. It will render futile and useless the requirement of the State statute that the lands to which the appropriation is attached must be described in the certificates, because the right can then be separated from this land without any legal formality as soon as the certificate is recorded. If water is to be so bartered and sold, then the public should not give streams away, but should auction them off to the highest bidder. Commenting on this decision, Fred Bond, State engineer of Wyoming, in his last annual report, says :-

There was nothing in the order of the board authorizing the use of any more water than the amount necessary for the irrigation of the land described, nor does it state what this amount is. The Springvale Ditch Company (the party selling the right) was not decreed the use of 1o cubic feet per second of time, nor was it given the use of any other spe- 


\section{IRRIGATION IN WYOMING}

cific number of feet of water; but it was decreed the use of water to irrigate 700 acres of land, an amount not to exceed I cubic foot per second of time for each 70 acres irrigated. In the view of the board there is a vast difference between the granting of the use of a flow of ro cubic feet per second of time outright and independent of use, and the granting of a sufficient flow to irrigate 700 acres of land. The wording of the decree shows this conclusively. The board did not undertake to designate the exact amount of water needed by the Springvale Ditch Company to irrigate the land described. In fact, it did not know.

In the settlement of Territorial rights, the first step is the notice of the survey. This is given by publication and also by registered mail to each of the claimants.

When the surveys are completed, the next step is the notice of the division superintendent to appropriators regarding the time and place of giving proof. With this notice is sent a blank statement which serves as a guide in the presentation of the facts which govern the amount and priority of rights. There usually goes also a letter intended to act as an additional guide to those not familiar with the working of the law.

The proof of the claimants is, as a rule, submitted by themselves. This proof is generally taken at some point within the irrigated territory most convenient of access to the water users. In extensive districts it is often taken at several points.

After all proofs have been submitted, a tabulation is made of the statements, showing the order 


\section{IRRIGATION INSTITUTIONS}

of priorities, the area, and description of the lands claimed to have been irrigated. This tabulation, together with the different proofs, is open for public inspection of all the claimants to water, and as a rule is critically scrutinized by other parties, although not always.

The certificate of appropriation issued by the board of control on the completion of its determination of rights, describes the land and places the limitation on the water right which is to govern the action of the water commissioner.

\section{Appropriation under State Laws}

The settlement of Territorial rights has now practically been completed, and hereafter the more important business of the board of control will be the supervision of future appropriations and the issuance of certificates of appropriation for the water actually used in order to govern and protect all interests and prevent disputes. The law provides that any party desiring to establish a right to water must, before he begins the construction of new works or the enlargement of old ones, secure a permit or license from the State engineer. The application for this license requires that he set forth in prescribed form -

The name and post-office address of the applicant ;

The source of the water-supply;

The nature of the proposed use; 


\section{IRRIGATION IN WYOMING}

The location and description of the proposed works ;

The time within which it is proposed to begin construction ;

The time required for the completion of construction; and

The time required for the application of the water to the proposed beneficial use.

In case the proposed right is for irrigation, the applicant gives the legal subdivisions of the land to be irrigated, with the acreage in each subdivision. It is further required that the application shall be accompanied by a map in duplicate, showing the course of the ditch, the course of the stream, and the lands to be irrigated. Before accepting the application the State engineer is required to make a careful examination of the filing and of the accompanying map. If there are errors, the papers must be returned to the applicant with instructions for their correction. When in proper form, they are accepted and filed. Then follows an examination of all the interests to be considered in connection with the new application. If it is found that there is unappropriated water in the stream, that the proposed use is beneficial and reasonable, that it will not impair existing rights, that it is not detrimental to the public welfare, and that the applicant is able to carry out the construction proposed, it is the duty of the State engineer to grant the permit. If, on the contrary, the proposed use threatens existing 267 
rights or seems to be made in bad faith, or is in any way prejudicial to the public welfare, it is the duty of the State engineer to refuse the permit. If the State engineer finds that the volume to be diverted is extravagant, or that any of the land described in the application cannot be watered from the proposed ditch, or that the time named in the filing for the completion of the application to a beneficial use is too great, he may make such modifications as shall bring the application within the purpose of the law. Construction cannot legally proceed until the State engineer has approved the application. This gives large powers to the State engineer, but the applicant is protected from arbitrary action by his right of appeal. Any person deeming himself aggrieved by any action of the State engineer may appeal to the State board of control. If dissatisfied with the findings of the board, he may carry the appeal to the district court.

After a permit is granted reports of progress are required, and a failure to go forward with the work within one year from the date of approval by the State engineer forfeits the right, and the permit is cancelled. This removes all uncertainty as to what rights on the streams are valid. A letter addressed to the State engineer concerning any appropriation or concerning all the appropriations on any stream will bring full information. This is an effective protection against over-diversion, and prevents any waste of energy and 268 
capital in the building of works for which there is no water.

The right to appropriate water can be obtained only by compliance with the law. Use without compliance will not answer. Rights cannot be established by prescription. Taking water from a Wyoming stream without a permit from the State engineer's office, or cutting timber from State land without a permit, are both misdemeanors, and for the same reason. Those who comply with the water law receive a definite title to water. The title comes from the State, and is a State patent to a share in the stream.

Upon the completion of the works, and when the water has been applied to the beneficial use proposed, notice is given to the State engineer, who makes an examination of the works and reports to the board. If the appropriation has been perfected in accordance with the terms of the application and the permit of the State engineer, a certificate is issued by the board of control. This certificate is of the same character as the one discussed in connection with the adjudication of Territorial claims. The priority of the appropriation dates from the time of filing the application. A right once certified can be lost only by failure to keep the works in order and to use the water for a period of two successive years. The State, after issuing these titles to water, protects them. 


\section{Distribution of Water}

This brings us to the last and most trying duty of the board,- the division of streams among those legally entitled to their flow. All that has preceded is simply preparatory to this. For convenience in distribution, and to secure prompt service in times of drouth, the four divisions are subdivided into districts. These subdivisions are made by the board as the necessity arises, and, like the greater divisions, their boundaries lie along the drainage lines. For each district the governor appoints a water commissioner, who has immediate charge of the water-supply in his district. Over him is his division superintendent, and the State engineer is over all. A table is prepared for each stream, showing the priorities and the volume of each appropriation. The commissioner is furnished with copies of this table so that he and the water users can have a clear understanding as to the relative rights of all who share in the use of the water-supply. When there is a scarcity, or some one is deprived of water to which he is entitled, the commissioner is called on to regulate the distribution. Each ditch-owner is required to place in his ditch a measuring flume and headgate, so that the volume diverted may be measured and the flow regulated. If the use of water by any ditch interferes with the rights of others having prior appropriations, the head-gate of the offending ditch is closed, wholly or partially. When a 
gate has once been set by a commissioner, it may not be changed or interfered with. The commissioners are clothed with police power necessary for the enforcement of the law.

The care with which the State guards these rights, causes water users to respect them. Instead of the uncertainty which once existed when each did what was right in his own eyes without regard to the rights of his more peaceable or less favorably situated neighbor, there is now certainty that each will receive his just share. If there is objection to any ruling of the commissioner, the rule is obeyed, but the matter is referred to the division superintendent. If his ruling is not satisfactory, the matter may be carried up to the State engineer or to the courts.

\section{Rights to Stored Water}

The Wyoming law making I cubic foot per second for each 70 acres of land irrigated the minimum duty of water was an amendment to the original act. It would have been much more convenient if the limit had been I cubic foot per second to 80 acres, but those who favored the amendment feared this would be too high a duty, and the one fixed upon was a compromise. There is no doubt it could be set aside if it could be affirmatively shown that more water was actually needed, but in no instance thus far has this been done, and with the higher duty of water which now prevails, it is doubtful if it ever will be. 
The Wyoming law contains no specific provision for establishing rights to stored water. The number and importance of the reservoirs recently built will make it necessary to have legislation on this subject, and the experience of Colorado will afford as valuable a guide in the future as it has in the past.

In I 894 Congress authorized every arid State to segregate a million acres of land and act as trustee in its irrigation and disposal to settlers. In accepting this act, Wyoming introduced some administrative features which have proven a complete success. In the first place, no projects are approved unless there is an ample water-supply. The lands to be irrigated are segregated by the State. No one is allowed to file on them except the shareholders in the ditches built to reclaim them. The ditches are not built by the State directly, but by parties who agree to sell them to settlers for a stipulated sum and who simply act as construction and colonization companies.

Under this act four large canals have been built and as many communities established in what were before desert solitudes. Since the passage of the law every large project in the State has been built under its provisions, investors in the ditches favoring it for these reasons :-

It prevents speculative filings on land.

The price at -which the canal is to be sold, is fixed by the State before the investment is made. This relieves the canal builder from litigation over 
water rights and the arbitrary reduction of rates by the county commissioners.

The law has the following advantages for the settler :-

Cheap land, - the State only charges fifty cents an acre; less than half the price asked by the United States under the desert land law.

The State investigates the water-supply and certifies that it is ample.

Each farmer becomes a part owner in the ditch, and his right to water attaches to his land.

Assurance from the outset that all the lands under the canal will be occupied by cultivators and that he will not be located in an oasis in which the surrounding lands will be held by nonresident speculators, who furnish no aid in securing local improvements, supporting churches and schools, and making social life attractive.

The ruling price for shares in the canal in the contracts thus far made has been $\$$ IO per acre. The minimum duty of water has been I cubic foot per second to each 80 acres. The transfer of the property to the farmers is to take place when from 75 to 90 per cent of the water rights have been sold. Prior to this transfer the company exercises the right to maintain and operate the canal and to charge the settlers the actual expenses of this operation. This is an advantage to both parties. It gives to the settlers the benefit of experienced management in the early years of the enterprise, and it gives to the in- 


\section{IRRIGATION INSTITUTIONS}

vestor control of the property until it has been sold.

In some of its details the Wyoming irrigation code needs modification, to adapt it to changing conditions, and because it was in the first place a compromise between the advanced views of reformers and the conservatism of those who wished to pattern after the older irrigation States. On the whole, however, the system justifies the commendation bestowed upon it by William E. Smythe in "The Conquest of Arid America":-

These laws and this administrative system have not only given peace and prosperity to the irrigation industry of Wyoming.... Other States have copied them extensively, and there can be no question that in the end they will become common to the entire arid region. Idaho, Nebraska, South Dakota, Kansas, and Washington have enacted portions of the Wyoming laws. In all the other States, with the single exception of California, the example of Wyoming has produced results, and there is hope that even California will learn in time that irrigation and litigation are not necessarily synonymous terms.

Wyoming's place as the lawgiver of the arid region is due neither to geographical location or to superior natural resources; certainly it is not due to large population. It owes its commanding position solely to the character and ability of a few public men who happen to have found in this line of work their best opportunity for usefulness. As a result of this fortunate circumstance, Wyoming occupies among western States, at the beginning of the twentieth century, a relation not unlike that which Massachusetts and Virginia held to the States of the Atlantic seaboard at the beginning of the nineteenth century. 


\section{CHAPTER XII}

Irrigation In the Other ARID ANd Semi-ARID States

The State irrigation systems described in the four preceding chapters illustrate the issues which confront Western irrigators. To describe the irrigation codes of the other States would be to repeat much that has been said in these chapters and would be neither interesting nor instructive. There are, however, no two States in which the irrigation systems are wholly alike, owing to the fact that each commonwealth has been free to frame its own laws and evolve its own customs. This statement applies to both laws and business methods. Some of the special features of the other arid States and Territories will be reviewed in the pages which follow.

\section{Arizona}

Water was used in irrigation in Arizona before the Nile was diverted by Joseph to protect Egypt from famine. The race which built these works, with their history and civilization, have long passed into oblivion, but the well-defined evidences of their engineering skill still remain. 


\section{IRRIGATION INSTITUTIONS}

Modern irrigation is of recent date. It began when military posts, established after the Civil War, protected settlers from the Indians. This opened up a region marvellously rich in mineral wealth. Food supplies for miners could be brought into the Territory from the outside world only at great cost. The products of irrigation sold for high prices, and this, combined with the fertile soil and almost tropical climate of the Territory, made the returns from an irrigated farm almost equal the dividends from a bonanza mine. The irrigator, therefore, followed on the heels of the miner and built ditches of a simple character, either by individual effort or coöperation, often without any legal formality or written agreement between those interested in the enterprise. These works were enlarged as there was need or opportunity, and repaired, as Eastern farmers improve roads, by assessments of labor rather than money. Until the coming of corporate canals and the introduction of corporate methods at a later date, irrigation development was simple, cheap, and wholly without legal regulation or control.

The first law for the appropriation of water was passed in $1864 .^{1}$ Its principal sections are still in

1 Section I. All rivers, creeks and streams of running water in the Territory of Arizona are hereby declared public, and applicable to the purposes of irrigation and mining, as hereinafter provided.

Section 3. All the inhabitants of this Territory, who own or possess arable and irrigable lands, shall have the right to construct public or private acequias, and obtain the necessary water for 


\section{IRRIGATION IN OTHER STATES}

force. All streams of running water were made public and could be used for irrigation and mining. Owners of fields were given a precedence in the right to use water, and priorities were to be determined by the dates when their lands were first occupied - the first settler having the first right. Water rights were, therefore, limited to water users and were attached to the land. No provision was made for the administration of streams, and without this these principles remained inoperative and dormant. Settlers who were familiar with the mining customs of California followed the practice of that State of posting notices on the banks of streams and claiming the water they proposed to divert, and this practice became general. These claims were usually for excessive amounts. Some of the earlier ones claimed all the water, and many of the later ones claimed all of the surplus water. The specific claims to water from Salt River ${ }^{2}$ amount to $42 \mathrm{r}, 680$ cubic feet per second, or more than the flow of the stream during its highest flood and twenty-five times its average flow for the past fourteen years.

the same from any convenient river, creek or stream of running water.

Section I7. During years when a scarcity of water shall exist, owners of fields shall have precedence of the water for irrigation, according to the dates of their respective titles or their occupation of the lands, either by themselves or their grantors. The oldest titles shall have precedence always.

2 Bulletin 43, Arizona Agricultural Experiment Station, by Professor Alfred McClatchie. 


\section{IRRIGATION INSTITUTIONS}

Many of the ditches for which water was claimed were never built, but the records still remain as there is no provision for their cancellation. The aggregate of the claims made in behalf of canals now in use amounts to about two and a half times their present total carrying capacity and more than double the average flow of the river. A single canal from the Verde, one of the tributaries of Salt River, claims more water than has ever run in that stream during any month of the past fourteen years.

The legislatures of the Territory of Arizona have made additions to the irrigation law until the system is now a mixture of Spanish law, Mormon customs, and a reflection of the judicial decisions of other arid States. Although the first law attached water rights to the land settled upon, the later ones, without repealing it, provide that any person or company may appropriate water for delivery to consumers, for rental, milling, irrigation, mechanical, domestic, or other beneficial uses. The later laws seem to ignore the land and to make the ditch a great factor in the appropriation of water. In principle, therefore, if not in express terms, they conflict with the earlier statute. These later laws attempt to protect irrigators by prohibiting canal companies from selling or renting more water than the estimated capacity of their work, but these statutes are of no real service. The estimated capacity of a canal depends largely on who makes the estimate; besides, the quantity of water which a canal 
can carry is not the factor which determines the water-supply of an irrigator. The vital question is whether or not there is water in the stream to fill it. The absence of any accurate record of the amount of water in use, or of any public control over construction or appropriation, has led to the building of more ditches and the selling of more rights than streams can supply water for.

Contests over water rights in Arizona are settled by litigation, and streams are divided by water commissioners appointed by the district judges. The water rights for nearly half the land irrigated in Arizona were established in a decree adjudicating the rights to water from Salt River, rendered by Judge Kibbey of Phœnix, Arizona, in I 892. This decree follows the statute of 1864 and makes the land the appropriator of the water and the amount of the appropriations depend on the acres irrigated. Although this decision has never been confirmed by the supreme court, it has attracted unusual attention because it has been practically the water law of Salt River Valley for a period of ten years. In this decision, it is held that canal companies are carriers of water; that pro-rating agreements are void because in violation of the statutes and acts of Congress, and that the first settler has the first right to the use of water, subsequent settlers following in order. It is further held that water rights are attached to the land where the water is applied and that a transfer of a water right cannot be made by a transfer of 


\section{IRRIGATION INSTITUTIONS}

stock in a ditch company. The weakness of this decision was its failure to describe the land to which water was attached. If this had been done, every one would have known what lands were entitled to water and what lands must acquire such rights. The failure to describe the lands made it possible to shift these rights and has created complications which render it uncertain as to what doctrine is ultimately to control in this Territory. All the decision did was to give the number of quarter-sections of land under each canal which were entitled to water, and left it for the owners of the canal to make the distribution.

The situation on the stream when this decision was rendered made it necessary that it should be put in immediate effect. A court commissioner was appointed for this purpose, and he was furnished by the court with a table for apportioning the water of the river among the several canals. It was made his business to determine where the lands were located and the amount of water which each quarter-section should receive.

While this litigation was pending, one of the larger corporations bought up a number of the smaller ditches or a controlling interest in the stock and endeavored to end the controversy by means of an independent agreement. Two of the litigants refused to sell, and this plan was not carried out, but a contract among the other companies was entered into which practically nullified the court decree by providing for the division of the water 


\section{IRRIGATION IN OTHER STATES}

allowed to all of the canals, except the Tempe and San Francisco, on an entirely different basis. A part of this contract was as follows :-

When the court shall determine and fix by decree the amount of water the Tempe Canal Company, and the severally associated plaintiffs having the right to use the water through and by the Tempe Canal, and M. Wormser, through and by the San Francisco, shall have the right to take from said Salt River in times of scarcity, then as between parties hereto the remaining waters of the said river shall be divided between the parties at the dam of the Arizona Canal, onethird to be taken out by the Mesa and the said Utah Canal companies by mutual agreement, or as their rights between them may be. And the other two-thirds shall be distributed between the Arizona Canal Company, the Grand Canal Company, the Maricopa Canal Company and the Salt River Valley Canal Company at their old dams, or through the Arizona Canal and the Crosscut Canal, as the said companies may mutually agree.

In this contract shares of stock are practically made equivalent to water rights. It is an illogical arrangement, because the number of these shares should be determined by the cost of building the canal or by the method of organization, and neither of these considerations has any direct relation to the area of land irrigated or to the necessities of that land. The owner of a large number of shares of stock in a ditch may not own an acre of land, or he may own large tracts of land on which water has never been used, while, on the other hand, the owner of the farm first irrigated, who according to the doctrine of beneficial use has a prior claim on 


\section{IRRIGATION INSTITUTIONS}

the stream, may be a very small stockholder in the ditch which supplies it. Under the court decree ditches were made carriers of water, but under this contract the ditches are made the owners of water. Under the court decree the revenue of these companies would come from payments for services rendered in carrying water from the river to the farms irrigated, the companies having no more ownership in the water than railroads have in the freight they carry. A decision of the district court rendered in Phœnix in $1900^{1}$ sustained this contract by holding that shares of stock in a ditch were practically the same as rights to water in the stream, but a later decision by the supreme court $^{2}$ upheld the original statute and made rights attach to the land where they were acquired, and their priorities to be based on the date of settlement and use.

In practice the owners of a number of Arizona ditches have treated shares of ditch stock as water rights, and have shifted the use of water from one piece of land to another without any regard to the dates when the land was settled. This shifting of appropriations has led to a rapid rise in the value of water rights. The owner of desert land can afford to pay a high price for shares of ditch stock which control early priorities, because it enables him to put his sage-brush and cactus acres on an equality with the farms first irrigated. The own-

1 James D. Mariar et al. $v$. The Maricopa Canal.

2 Slosser $v$. The Salt River Valley Canal Company. 


\section{IRRIGATION IN OTHER STATES}

ers of the farms first brought under cultivation have been tempted by these high prices to sell their water shares, but in doing this they contribute to their own downfall, because both land and water have to be used in order to cultivate the land, and the profits of this cultivation in the end determine what the land and water together are worth. If one of these two elements of production increases in price, it must reduce the value of the other, and as ditch stock, or, as it is called there, "water stock" has risen, the price of land has diminished. During the past five years the price of shares in old ditches has nearly quadrupled, while the price of farming land has in some instances grown less. There can be no continuous increase in the combined value of land and water so long as the profits of agriculture do not increase; and if it shall be finally held that the water shares can be transferred separately from the land, it will practically result in making all agricultural values in this section inhere in the water, because whoever controls the water will have the power to determine what lands shall be productive and what shall be almost valueless.

With the exception of the Colorado, all of the streams of Arizona become very low in midsummer. Storage, therefore, is of unusual importance. Without regulation there is scarcely a stream in the Territory where all of the water can be used and none where it can be used to the best advantage. A law for the construction of reser- 


\section{IRRIGATION INSTITUTIONS}

voirs was passed in 1893. Under it, water turned down a natural channel to be diverted below is subject to a deduction for seepage and evaporation of one-half of one per cent for each mile of the distance travelled. A law authorizing the bonding of counties to construct public storage works was passed in rgor.

The exceptional value of water in Arizona, the wide fluctuation in the flow of streams, and the need of storage for their regulation make the need of public supervision over the establishment of water rights and their protection in time of scarcity of more than ordinary importance. Without this, there must always be controversy and litigation. The situation on the Gila and Salt rivers illustrates what will take place elsewhere if the present haphazard methods are to be continued. In I 890 the region around Florence, a town on the Gila, was well cultivated and prosperous. Since that time ditches have been built many miles above. The ranches lower down cannot be watered with what comes to them and are going back to aridity. In a less degree the settlers around Phœnix have suffered from the diversion of water from the Verde, one of the tributaries of Salt River. These interfering ditches are from 30 to IOO miles above Phœnix; they take water when it is most needed as well as when it is most abundant, and aggravate the injury by wasteful use in times of scarcity. Lack of public control, therefore, allows one community to be built up at the expense of an older 
one. It will be nothing less than calamitous if these differences are left to be settled by litigation. It will array one section against another, and the bitterness of feeling thus aroused will add to the difficulties of subsequent administration. Here, as elsewhere, there is urgent need of public administration of streams. The granting of titles to water, like the establishment of titles to land, should be a ministerial and not judicial function; and the legal warfare over water, which is the most serious menace to irrigation in Arizona, is due largely to the failure to provide for this.

\section{New Mexico}

The Rio Grande and Pecos are the chief rivers of New Mexico. The oldest irrigation works now in use in this country are on the Rio Grande, where Spaniards were irrigating the bottom lands around Las Cruces when the Mayflower landed at Plymouth. Most of the ditches along this stream are owned by Mexicans, and custom, as old as settlement, rather than statute law, governs the distribution of water. It is otherwise along the Pecos, where irrigation is of recent date, and where for many years the range cattle business was of first importance. There are Mexican settlements along the Pecos which are still ruled by the customs of their forefathers, but on the main stream the methods of irrigation have been largely borrowed from Colorado. The irrigation works of this val285 
ley are notable both for their cost and the results which have been obtained. In all, several million dollars have been expended and an oasis has been created in the heart of the waterless, treeless Southwest. The first enterprise was a financial failure. It was too far from markets and too far from settlement. In other ways it was a success.

Near the town of Carlsbad, a Swiss colony built homes and planted gardens which were not surpassed in taste and beauty in any section of the country. In other ways the Territory has been greatly benefited. Irrigation has been the cause of the construction of one railroad and an important influence in the building of another transcontinental line.

The water laws of the Territory of New Mexico exert little practical influence. One reason is that they are simply declarative. No public control is exercised over the division of water; there is no means of settling priorities or amounts of appropriation except through litigation. Another reason has been the fact that irrigation settlements on the same stream are widely scattered and one community has little knowledge of what is being done elsewhere. Thus far there has been little friction and scarcely any controversy over water rights.

On the Rio Grande each irrigated section regards itself as practically independent of the other. Whenever there is a flood, all have enough. When there is a drouth, nearly all have to do without, 
and no economy nor improvements -in distribution would relieve the shortage. It is also probable that irrigators are on better terms with each other because of their common grievance against Colorado, where the river is diverted before it reaches them.

Two reservoirs have been constructed in the channel of the Pecos. The largest has an area of 8000 acres, and supplies the irrigated land in the vicinity of Carlsbad. Its success has stimulated reservoir construction throughout the Territory, and two large reservoirs have been planned on the Rio Grande. One, begun by a private corporation, has been delayed by litigation. The other is an international project intended to store water as a means of settling the controversies between the United States and Mexico over the use of the Rio Grande in this country.

In 1898 Congress gave New Mexico 500,000 acres of land as an aid to the construction of reservoirs. This land can be sold only in tracts of 160 acres to one person and for not less than $\$ 1.25$ an acre. The Territorial act, accepting the grant, authorizes the commissioner of public lands and territories to contract with parties to build reservoirs, no one contract, however, to involve the control of more than 50,000 acres. The cost of these works is to be paid out of the rentals and sales of land. Ten corporations have been formed for carrying out these projects, but it is probable that the act of Congress providing for the construction 


\section{IRRIGATION INSTITUTIONS}

of National works will supersede development under the Territorial law.

The courts of New Mexico have taken advanced ground on the subject of water rights. In a recent decision ${ }^{1}$ it is held that in order to acquire a water right in New Mexico the proof must show the land which was irrigated and the years it was irrigated; that it is not enough to show that the ditch exists for the diversion of water. If this ruling is adhered to, beneficial use of water in New Mexico will mean more than it does in some sections of the West. It will prevent the evil of excess decrees, because the needs of the land will always serve as a measure of the right.

\section{Kansas}

Kansas is on the border-line of irrigation. In the eastern two-thirds of the State irrigation is not necessary; in the western third it is. But this fact was not realized until nearly the whole of western Kansas had been settled and an attempt made to cultivate the soil by rainfall alone.

The two perennial streams of western Kansas are the Arkansas and the Republican. Both depend on other States for the greater part of their flow. The surface water of these streams is insignificant as compared with the greater volume which travels slowly underground. Settlement disregarded both the surface and the underground channeis. It covered the whole coun-

1 Pacific Reporter, Vol. 6r, p. III. 
try, and when it was found that irrigation was a necessity, the settlers on the upland plains sought a water-supply in small reservoirs and in wells. Because of this the laws of Kansas give particular attention to the protection of rights to underground waters. Those who wish to establish priorities for such supplies have not only to file notice in the county where the well is situated, but also in adjoining counties. These notices are in part for statistical purposes, but in part to enable other appropriators, who might be injuriously affected, to take steps to protect their rights. The statistical feature alone would render this record valuable, but that value would be enhanced if wells were also recorded in some central office, in order that the records might be conveniently studied by those having especial interest in these questions.

Irrigation began in the vicinity of Garden City and Fort Dodge. A number of large and costly canals were built, as well as many smaller ones, the investment reaching into millions. The Arkansas River did not carry water enough to make these works of value to farmers or profitable to their owners. Recent development has been in the direction of storage works, and one of the largest reservoir projects in the country is located on this stream.

Under the earlier laws of Kansas riparian rights were recognized, but the Act of 189 I gives the right to appropriate water west of the 99 th meridian. 
So far as the declaratory provisions of the Kansas laws are concerned, there is much to commend. They are generally in accord with the best thought and experience of the West; but when we come to consider the means provided for their administration, the result is not so satisfactory. Chapter 79 of the compiled laws of 1897 provides for the appropriation of water from streams and wells, and restricts the right to beneficial use, and that whenever such use ceases, the right terminates. Appropriations are limited to the quantity used, and any person attempting to sell, lease, or assign a right is held to have abandoned it. Under this law the speculative ownership of water is rendered impossible.

Exclusive jurisdiction of all matters relating to water rights is given to the district courts, which are empowered to appoint water bailiffs to enforce their decrees. The commissioner of irrigation and forestry, the only State official who is supposed to be an expert in irrigation matters, has no authority whatever.

\section{Nebraska}

For many years the people of Nebraska had a prejudice against irrigation. Farming in the eastern half of the State was a success without it, and settlers believed that clouds and rains would move westward with the construction of railroads, the ploughing of the soil, and the building of houses. Confidence in the rainbelt theory was strengthened 
by the wet years of $1883, \mathrm{I} 884$, and 1885 . Many years of loss and of hardship and suffering followed before this delusion was overthrown. In this time thousands of hopeful, industrious men not only lost the savings of a lifetime, but the energy and ambition with which to renew the struggle for a competence under more favorable conditions. Where it was possible to build canals, irrigation alleviated these disasters, but many of the upland farms have been abandoned.

The first irrigation law, passed in 1877 , made irrigation canals internal improvements and gave corporations organized to build them power to condemn rights of way. In I889 an act established the doctrine of appropriation as a part of the water law of this State, section I, article I reading as follows:-

The right to the use of water flowing in a river or stream, or down a canyon or ravine, may be acquired by appropriation by any person, or persons, company or corporation organized under the laws of the State of Nebraska, provided that, in all streams not more than 50 feet in width, the rights of riparian proprietors are not affected by the provisions of this act.

In I895 Nebraska adopted a system of State administration of streams which resembles very closely the Wyoming system. A board, consisting of the governor, attorney-general, and commissioner of public lands and buildings, has control of streams and of their use in irrigation. The secretary of this board is its executive officer and performs all the duties of a State engineer. $\mathrm{He}$ 


\section{IRRIGATION INSTITUTIONS}

is not given this title, because the State officers are named in the constitution, and an engineer is not included among them. The secretary has two assistant secretaries who are in fact superintendents of irrigation. Each has charge of one of the two water divisions into which the State is divided. No. I includes the Platte and its tributaries west of the mouth of Loup River, and No. 2, the Loup, White, Niobrara, Elkhorn, and all other lands not included in division No. I. The State is further divided into water districts, for each of which an under secretary or water commissioner is appointed.

When this board was organized in April, r895, it was confronted by the same difficulties that beset the Wyoming authorities. For years, ditches had been built without regulation or supervision. There was no record of priorities and the lawsuits which had taken place had complicated rather than settled the ownership of streams. Since that time the chief endeavor of the board has been to bring order out of this chaos. In this it has made rapid progress. The rights of 463 appropriators have been determined and 407 permits for new ditches, covering in all I,700,000 acres of land, have been issued.

The attorney-general is a valuable member of the board, but it would be an advantage if more members were men skilled in irrigation affairs. This weakness has thus far had little practical weight because the secretary who acts as State 
engineer has been given a large measure of discretionary authority. Since the inauguration of public control of streams, irrigation matters in Nebraska have been well managed. Owing to the care taken to determine the lands actually irrigated, excessive appropriations have been prevented and this has led to a general acceptance of the board's action. The size of ditches has had no weight except that they must be large enough to carry the water needed. It is the use of the water which controls. The law makes one seventieth of a cubic foot per second the maximum volume which can be diverted for the irrigation of an acre of land. This has to be measured at the head-gate; hence, it includes losses from seepage and evaporation in transit. Aside from litigation over riparian rights, there have been no legal contests of importance.

The Loup and the Platte are the two large rivers of Nebraska. Both are perennial streams, easily diverted, and bordered by broad, gently sloping valleys. Irrigation along the Loup has suffered from the tendency of farmers to depend on rain. This causes them to refuse to enter into continuing contracts and makes the annual income of ditch companies uncertain. The most serious obstacle, however, is the conflict between the common-law doctrine of riparian rights ${ }^{1}$ and the right of diversion and use of water under the doctrine of appropriation. The riparian statute

1 Section 2088 of the Consolidated Statutes of 1891 . 
was a part of a law passed in $\mathbf{1} 866$. It reads as follows :-

So much of the common law of England as is applicable and not inconsistent with the constitution of the United States, with the organic law of this Territory, or with any law passed, or to be passed, by the legislature of this Territory, is adopted and declared to be the law within said Territory.

Although the supreme court has made a number of decisions interpreting this statute, its meaning is still in doubt. In Clark $v$. Cambridge and Arapahoe Irrigation and Improvement Company (45 Nebraska, page 798), it is held that the common-law doctrine with respect to riparian proprietors prevails in Nebraska except as modified by statute, but as it has been practically repealed by statute, this is not conclusive. In a recent decision, however (Crawford Company v. Hathaway, $60 \mathrm{Ne}-$ braska, page 754), the court throws so much doubt on the question of whether the common law supersedes the right to divert streams as to cause grave apprehension among irrigation interests. There have been two re-hearings of this case, but a final ruling has not yet been rendered.

Rights of appropriators are protected by water commissioners. The State is divided into districts based on drainage lines. Five districts have been created in division No. I. Commissioners are paid by the counties in which services are rendered. Nebraska is exceedingly liberal in its treatment of irrigators. There are no charges for 


\section{IRRIGATION IN OTHER STATES}

surveys made in the determination of appropriations, and in taking testimony the only expense which appropriators have to meet is the charge for a stenographer.

\section{South Dakota}

The most successful irrigated district in South Dakota is the region surrounding the Black Hills. The streams which flow out of these mountains furnish a valuable means of supplying the home markets of the great mining camps of Deadwood and Lead City. In the eastern and central part of the State irrigation has never received much attention. But little has been done to divert and use the Missouri, and for some reason not known there has been a falling off in the irrigation from artesian wells. Interest in irrigation development is, therefore, confined to the extreme western portion of the State.

.The subject has received but little attention from the State legislature. The laws provide that the holder of a possessory right to mineral or agricultural lands shall be entitled to use streams, and they require the filing of a certificate of location and the posting of a copy of this notice at the head of the ditch. There is also provision for the incorporation of ditch companies, which are required to begin work within ninety days after their formation. A law passed in 1897 indicates that the people of the State do not look with much favor on the serious diminution of streams by irrigators, 
as it permits the appropriation of only the surplus waters of lakes, rivers, and creeks. Inferentially it does not authorize the use of the normal flow. The question at once arises: What is the surplus flow of a stream, and what is the surplus depth of water in a lake?

In the region around the Black Hills a right to divert the surplus waters has little value, because crops need irrigation as badly in July, when streams are below their normal flow, as in June, when they are above it, and a right which does not extend to the maturing of crops is hardly worth considering.

The limitation on the use of streams does not apply to underground waters. Any person can sink artesian wells on land he controls, and store, lease, or sell the waters obtained therefrom. The location of these wells is, however, subject to State supervision. Private wells are not permitted to reduce the flow of other wells already in use. Wells may also be dug as municipal works, the law authorizing their sinking by townships and incorporated villages. But little money has, however, been invested in this sort of development.

South Dakota has a State engineer, but his only function is to act as a collector of statistics. Titles to water are settled in the courts. There is no statutory form of procedure, and no provision for compelling all appropriators from a single supply to have their rights determined at one hearing. 
IRRIGATION IN OTHER STATES

\section{Montana}

The largest river flowing from the eastern slope of the Rocky Mountains rises in Montana, and every important mountain tributary of the Missouri, except the Platte, rises in or flows into this State. The Missouri and Yellowstone drain a region of unusually heavy snowfall, and all of the principal streams of Montana have a large and perennial discharge. The diversion of the Missouri is difficult, but means will be found to overcome its obstacles. The water-supply of Milk River is inadequate, but measures are already under way to reënforce this by diversions from other streams.

The small agricultural development of Montana is not due to physical obstacles but to the fact that the range live-stock industry has been so profitable that settlers have found free grass more attractive than cultivated crops. Whether the superior natural pasturage of Montana is due to favorable soil or slightly greater rainfall is not certain, but it is probaby the latter. Whatever the reason, it is certain that grass grows more luxuriantly here than in States farther south. Recent developments give grounds for the belief that a considerable portion of this State's area is susceptible of being cultivated without irrigation. In the vicinity of Great Falls, Bozeman, and in the valley of the Blackfoot there are comparatively large areas where all the cereals and alfalfa are being 


\section{IRRIGATION INSTITUTIONS}

grown with excellent results. The favorite locations for dry farming are on the western and northern slopes of the mountain ranges and on some of the plateaus where there is more than an average rainfall. It is certain that success in dry farming is to have an important economic bearing on the extent of the reclaimed area. The fact that crops can be grown without irrigation means that less water will be required for irrigation and that the area which streams will serve can be correspondingly extended. It means that by deep ploughing, by winter irrigation and the construction of reservoirs enough moisture can be conserved to farm far more land than would be possible with an equal amount of water in States like Colorado or in Territories like Arizona.

As yet, this greatness is largely prospective. Far more water runs to waste than is used. Nevertheless, the future of irrigation is abundantly foreshadowed by what has already been accomplished. The excellence of the fruit of the Bitter Root Valley has become known all over the country, and the barley of the Gallatin Valley has an international reputation. Corn is successfully grown on the lower Yellowstone, and everywhere the combination of stock-raising and farming has been so profitable and successful that its rapid extension is one of the certainties of the near future.

In the mileage of ditches and acres of irrigated land Montana stands third among the arid States, but this development rests on a wholly inadequate 
foundation of statute and organic law. Little attention has been given to water-right questions because the water-supply of the State is so abundant that this has not been necessary. In few States of the Union are streams as uniform in their flow as in Montana. Yellowstone Lake is a great natural regulator of Yellowstone River. It holds back the floods of spring and relieves the shortage in midsummer. On the Missouri and most of its tributaries irrigation has not thus far reached the limits of the low-water discharge and has made little diminution of the floods. Nevertheless, there are streams where irrigators' rights need protection, where controversies have already become acute. Here there is need of some final settlement of titles to the supply in times of scarcity.

The irrigation code of Montana was copied largely from the laws of California. It is a fairly satisfactory law for the miner, but a poor law for the irrigator. The fact that a water law which will work well for one industry is not suited to another is not as well understood as it should be in the West. It is, however, just as true as the fact that one land law will not work equally well in disposing of both mineral and agricultural lands. The government has recognized this and has enacted one law for disposing of placer claims, another for coal lands, and another for agricultural homesteads. In other words, the land laws conform to conditions, and water laws should do the 
same. The difference between mining and irrigation is that the use of water in mining is regular and continuous. In irrigation it is intermittent. It ceases entirely in winter and varies from day to day in summer. In mining, little of the volume diverted is permanently lost. It is returned to the stream and can be appropriated and used over and over again. In irrigation an average of twothirds of the water diverted is dissipated. It matters little whether rights to water in mining are personal property, because there is no final disposal of the water. It comes back again to public ownership and public control. But when rights to water for irrigation are made personal property, it means a final control and disposal of the supply.

The absence of any public administration of streams in Montana and of any public supervision over the filing of claims to water makes it impossible to state definitely what are the limitations on water rights in that State. The only light which has been thrown on this subject has come through the decisions of the courts in litigations over this question, but these are not sufficiently consistent to form a definite policy. In some cases, appropriations have been held to be personal property, but not always. In one conspicuous instance this has been denied. Appropriators as a rule believe that they acquire personal ownership in streams and that they can rent, sell, or use the water controlled as they see fit. Some 
of the court decisions go to greater lengths in support of this belief than do the decisions of any other State. In one instance, an appropriator was held to have acquired a right to water for land on the south side of a stream, although the only ditch which he had dug and all the land which he had watered were on the north side.

The records of claims to water in Montana are exceedingly indefinite and unsatisfactory. Claims are filed in the different counties, and as Montana rivers are long, the water-right records of a single stream are often found in several counties. Musselshell River forms a part of the boundary between Fergus and Meagher, Yellowstone, Dawson, and Custer counties. Ditches on one side of the stream are recorded in one county, and ditches on the other side of the river in another county. It would require a journey of several hundred miles and an examination of five sets of county records to ascertain the extent of the claims to this stream. An examination of claims to water from the Yellowstone and Missouri would be a more serious undertaking, and is practically out of the question at present because of the time and expense it would involve. Because of this, very few irrigators know what has been claimed by others and attach little importance to what they have claimed themselves.

The great abundance of water in Montana $30 \mathrm{I}$ 
threatens to lead to the establishment of excess rights which will prove a serious obstacle to development in the future. No irrigation statute of any State goes farther in the direction of speculative ownership of water than section I897 of the Montana irrigation code, which reads as follows : -

Every person having the right to use, sell, or dispose of water and to engage in using, selling or disposing of the same, who has a surplus not used or sold, or any person having a surplus of water and a right to sell and dispose of the same, is required, upon the payment or tender to the person entitled thereto an amount equal to the usual and customary rates per inch, to convey and deliver to the person such surplus of unsold water.

Rights to water in Montana are determined by the courts, and as there is no general record of these determinations, there is great difficulty in finding out what has been done. Where the suits in the district court are not appealed, nothing but a search through the court's docket for all the years that have elapsed since settlement began will finally determine what rights have been adjudicated. As many of these decrees are rendered in suits which are indexed in the name of the litigants, it is very difficult to determine what lawsuits have involved settlement of titles to streams. In an effort to trace down the waterright litigation on one of the creeks of this State, it was found that the court and county authorities were as much in the dark regarding the actual situation as the writer. 


\section{IRRIGATION IN OTHER STATES}

In looking through the records - of Silverbow County, Montana, it was found that at some time in the seventies two neighbors became involved in a lawsuit over their water rights. This lawsuit was entered in the name of the litigants. The decision was apparently satisfactory, because there was no appeal, and it is presumed that for a time it governed the division of the stream; but as time went on, one of the litigants died and the other moved away. New parties came in possession of their ranches. The old water suit was forgotten and the new owners disagreeing, another contest over the stream was instituted. There were two trials in the lower court and an appeal to the supreme court. Large sums of money were spent in the contest and witnesses brought from different States to testify. Everything which was known to favor either litigant was produced, but nowhere in this protracted contest was the original suit referred to. It had evidently been completely forgotten and all trace lost until overhauled in a complete search of the old records made by the writer.

The certainty that Montana is to have a rapid growth in the future, the equal certainty that there will come with it a need for a definite and final settlement of water titles and for their public protection, renders a change from the present lack of system and control one of the most urgent needs of the near future. In order to show how inadequate and ineffective are the present laws, the 
following history of a typical water-right lawsuit is given.

In 1864 two men settled on unsurveyed lands along Middle Creek, six miles west of the town of Bozeman, Montana. In the autumn of that year each of these settlers conveyed about one hundred miner's inches of water to his land through a ditch taken from the above-named stream. Between I 864 and 1869 a number of new settlers occupied lands along the stream. Each constructed his own ditch or acquired an interest in his neighbor's ditch. These settlers, to the number of thirteen, diverted the stream at various points along the lower nine miles of the creek and became known as the Lower Middle Creek appropriators. Lands had been filed upon prior to 1870 on the upper part of this stream, but no water had been diverted. This was due to the greater cost of building ditches and to the fact that the lower irrigators had acquired prior rights to the stream, and might contest diversion by the settlers above. To overcome the physical obstacles and to procure means of litigating their rights to water, the settlers on the upper part of the stream formed an association called the Upper Middle Creek Ditch Company. For the purpose of avoiding a conflict, this association negotiated with its neighbors on the lower part of the stream for the purpose of reaching an agreement regarding a division of the water. In $187 \mathrm{I}$ this resulted in a contract signed by both parties interested. It provided for exchange of irrigation 


\section{IRRIGATION IN OTHER STATES}

waters, conceded to the lower users their prior rights to the extent of the capacity of their several ditches, and agreed to construct a canal which should convey water from the Gallatin River to Middle Creek above the head-gates of the lower users, and thus reënforce their supply. The upper irrigators believed that they would be entitled to take from the upper part of Middle Creek as much water as they turned into it from another source; and the contract stipulated that the holders of the prior rights below consented to this arrangement. The contract was signed by nearly all of the lower appropriators but was never acknowledged or recorded. The supply ditch was built and the diversion ditches from the upper part of the stream were also built. This did not prevent disputes over water, but they did not result in litigation until I883, twelve years after the signing of the agreement.

In April, I883, the lower appropriators to the number of thirty-nine brought suit against the appropriators on the upper part of the stream. The lower irrigators had just cause for complaint. The Middle Creek Ditch Company had failed to maintain the supply ditch from Gallatin River, and the later appropriators above had diverted the greater part of the stream, causing it to become dry at times above the head-gates of the lower ditches. The suit was begun in April and a decision rendered in October, in which 2415 miner's inches was decreed to twenty-five plaintiffs below and 249 inches to 
thirty-nine defendants above. Little benefit resulted from this decision. It is only referred to as preliminary to the greater contest which afterward took place. This began in I 889-90, when the Middle Creek Ditch Company began a contest against the upper irrigators, twenty-two in number, who had settled on the bench lands near the canyon. More than two years elapsed between the time of issuing the injunction against the defendants and the beginning of a trial. In July, I890, they were restrained from interfering with the waters of Middle Creek, and in November, I 89 I, the trial began. It lasted twenty-three days, and the decision held that the lower claimants, by the contract of $187 \mathrm{I}$, had abandoned all right and interest in the natural flow of Middle Creek. This ruling was extremely adverse to the Middle Creek Ditch Company, as it changed the date of nearly one-half of its appropriation from the years I864, I865, I866, I867 to a date later than the contract, or $187 \mathrm{I}$. The plaintiff appealed the case to the supreme court, which in 1895 reversed the ruling of the lower court and remanded the case to the lower court for a new trial.

Six years of litigation had done nothing toward a final settlement. The long-continued contest had converted friends into enemies. The uncertainty regarding the control of water had diminished the acreage irrigated, and the heavy assessments to maintain court expenses had de- 
prived many of the farmers of comforts needed at home. What was wanted now was peace at any cost. The irrigators had neither the means nor the disposition to continue the court warfare, and made a compromise which the court afterward embodied in a decree. Professor S. Fortier, of Bozeman, Montana, from whom the above facts were obtained, made the following comment :-

It tells the old familiar story of heroic efforts to subdue a desert and at the same time maintain an action in court over a contested water right.

From 189 I to 1895 , inclusive, a period of five years, the Middle Creek Ditch Company levied in cash assessments $\$ 5259.50 . .$.

The writer has had no opportunity to ascertain accurately the aggregate cost to all the litigants. It is safe to say that if all the losses in time and money incurred by the irrigators on this stream in defending their rights to water were reckoned the sum would reach $\$ 13,000$.

The aggregate quantity of water decreed is 136 secondfeet. Assuming the present commercial value of a secondfoot of water, or 40 Montana statutory inches, in Middle Creek to be $\$ 300$, the total value of the water adjudicated would be $\$ 40,000$. That is to say, it has cost nearly onethird what the water is worth to obtain a judgment, and this judgment is of little practical benefit to the irrigators because it exists only on paper. There is not a single measuring device on any of the ditches by means of which an appropriation can be measured. The distribution is at present only guesswork, just as it was before a decree was rendered.

The protracted litigation over the water-supply of Middle Creek might have been averted under good water laws and an effective administrative system. If the State had kept a record from the first of the dates of appropriations and the 307 
volumes annually diverted, the spending of twenty-three days by the court at one session in recording well-nigh worthless testimony would have been wholly unnecessary. Under a system of long-continued recorded measurements decrees might be given in accordance with facts; as it is at present they are too frequently based on the wild guesses of interested witnesses. The judiciary is in no way responsible for the present senseless mode of settling rights, the blame rests with the State legislature. It is true that in the cases reviewed, there were questions of law to be decided, such as the exchange of water between two communities of irrigators, and the abandonment of claims to water. Such questions, however, should have been settled years ago by legislative enactments. Under a wise irrigation code, enforced by competent administrative officers, it is safe to say that nine-tenths of the water suits that now burden the courts would have never arisen.

It is believed that the experience of Montana, and the contrasting conditions in Canada on the north and Wyoming on the south, favor the following changes in the present code:-

All records of claims or titles to water from a stream should be kept in one office.

There should be some authority to supervise the filing of claims and to prevent the over-appropriation of streams.

Completed ditches should be measured by the State and rights established by some less costly method than litigation.

The State should be divided into districts and officers should be appointed to protect rights in times of scarcity. 
IRRIGATION IN OTHER STATES

\section{Idaho}

Irrigation in Idaho began in an overflow of Mormons from Utah. It was easy to build ditches from small streams in the southern part of the State, and as the demand for new farms outran the supply in the parent colony, Utah methods of building partnership irrigation works were extended northward. These emigrants also took with them the Utah customs of managing canals and of dividing the water-supply by time rather than by volume. The practice in Utah of establishing farming villages and giving to each settler in these villages a tract of from two to ten acres for a garden and the support of a few domestic animals, was also followed. The farms, however, are larger than in Utah, because the settlers were farther removed from the influence of the church authorities and stock-raising as an adjunct to farming made larger holdings desirable. Less land is devoted to cultivated crops and more to native hay than in the valleys of Utah.

In western Idaho irrigation began by miners turning farmers and by stockmen building irrigation works in order to control the water fronts and to be enabled to raise hay for winter. The early agriculture of western Idaho had little to commend it. It was wasteful of water and injurious to the land. With the construction of the Oregon Short Line Railway and the influx of capital for the irrigation of the higher lands, development took a 
corporate form. The works built were of a more substantial character and water began to be used with more economy and skill. The story of the Chosen Valley, by Mary Hallock Foote, gave a lifelike portrayal of the difficulties which have confronted canal builders in western Idaho. In no part of the arid region has the construction of large irrigation works been attended by more vexatious or persistent obstacles. The poorly built ditches of the first settlers which watered the bottom lands cost but little; the larger and more substantial works built by Eastern investors to water the bench lands were much more expensive and higher charges for water were necessary. Settlers rebelled against paying these, and many who filed on lands refused to cultivate them. For years, the large canals which divert the waters of the Boise, Payette, and some other streams have not watered half of the lands under them. Because of this, some of these projects have been financial failures, and the owners, tiring of them, have sold them to the landowners. To-day but one irrigation system in southwestern Idaho is owned and operated by others than the farmers who take water therefrom.

The water laws of Idaho are inadequate. The State engineer has no control over the diversion of streams. There is no central office of record for either water filings or for the rights decreed to be vested by the courts. The only means provided for the establishment of rights is an 
action in the courts, and the only means for protecting these rights is to have the court appoint a commissioner to carry out the decree. The official duties of the State engineer relate almost entirely to the material development of the State. He is required to collect facts and ascertain locations for reservoirs and the cost of their construction, and to become familiar with the means of diversion and supplying water to the irrigable lands. The great questions of appropriation and ownership of streams are, however, left entirely to the courts. The efforts of Hon. D. W. Ross, State engineer, for the improvement of waterright contracts, for the limitation of rights to the actual needs of land, and for the attachment of rights to the land rather than to make them shifting personal property, has had much to do with the moulding of public sentiment in that State, which it is hoped will in time be reflected in its legislation.

It is the belief of the State engineer that water rights are appurtenant to the land where acquired, and in a few instances they have been made so in the court decisions, but in all.of the decrees examined by the writer, the water does not seem to be attached either to any particular tract of land or to any particular ditch, but to be appropriated without conditions as to place or manner of use. It is difficult to see how such rights can be construed as other than a gift to the appropriator of the amount of water named in the decree, and it is more 
than probable that these appropriators will attempt to rent and sell these rights as appropriators are doing elsewhere under like conditions. One thing is certain: the decrees do not contain sufficient information to guide a water commissioner in the proper performance of his duties. He cannot enforce economy because he has no standard by which to measure economy. He does not know where the water granted is to be applied. He does not know how much water an acre of land is entitled to. All that he can learn from the decree is that certain individuals are entitled to a certain amount of water, and it apparently rests with those individuals to say where it is to be delivered.

\section{Nevada}

Nevada has the distinction of having a river which rises within its borders and sinks before it leaves them. Interstate water rights are of no concern on the Humboldt. The Truckee, Carson, and Walker rivers rise in California and flow into Nevada. The Salmon, Bruneau, and Owyhee rise in Nevada and flow out of the State. The Colorado forms the southeastern boundary for a distance of 150 miles, but is not claimed as a Nevada river.

The legal recognition of irrigation began in $\mathrm{I} 866$. The law of that year requires any party desiring to construct a ditch or flume to record, in the county in which the ditch was to be built, a certifi- 


\section{IRRIGATION IN OTHER STATES}

cate and plat. This record was intended to give constructive notice to all other proposed appropriators. This law, like so many of the western irrigation laws, permitted the indiscriminate filing of indefinite and ridiculous claims.

Twenty-three years elapsed between the first irrigation act and the second. In I889 an act for the filing of claims, giving the names, post-office addresses, names of the ditches, locations of headgates, and providing for special books of record, was passed. This law also provided for the division of the State into districts along drainage lines. Commissioners were to be appointed in each district to control the distribution of water. Questions of priority were to be settled in the district courts, and no person was to be allowed to testify until a certificate of claim had been filed in accordance with the law.

The first effect of this act was a rush of statements to the recorder's office. These included anything which could under any circumstances be called a ditch. They included main ditches, laterals, old river channels, and neglected sloughs. In some cases the main channel of the river was claimed as a ditch and the water declared to have been appropriated by original construction.

This act was repealed four years later, and nothing further was done toward the enactment of an irrigation law until 1899 . The law passed in that year was intended to inaugurate a system similar to that of Wyoming. The county commissioners 


\section{IRRIGATION INSTITUTIONS}

and county surveyor of each county were to constitute a board of water commissioners, with duties and powers almost identical with those of the board of control in Wyoming. The bad feature of the law is that the administrative unit is the county and not an entire drainage basin. The act leaves it to the discretion of county commissioners as to whether they will put the law in operation. No board has done this, and the law has been practically a dead letter. The original law of I866 is, therefore, the only one actually in force, and there is no way of settling controversies over water except in the courts. Litigation has been characterized by great cost and barrenness of results. Where a litigant has gained a certain volume of water in a decree, he has had no means of protecting his right. He must either resort to force or institute contempt proceedings, and he generally chooses the former. The lesson of Nevada, as of other states, is the need of administrative control.

\section{Washington}

Washington is a State of climatic contrasts. There are places west of the Cascade Range where more than seven feet of rain falls every year. The giant forests which clothe the western slopes of this range, the exuberant vegetation which covers the hillsides, and the green grass and beautiful ferns which are found in the valleys, show that there is no need of additional moisture. 


\section{IRRIGATION IN OTHER STATES}

To a less extent the same thing is true of eastern Washington. The rolling hills of the Palouse country are one of the great granaries of the West, but irrigation had no part in making them such. The same is true of the orchards which surround Spokane, Pullman, and Colfax.

It is far different, however, in central Washington, where the annual rainfall is only about ten inches, and where cultivated crops cannot be grown without an additional water-supply. The Yakima River is the great industrial factor of this part of the State. Rising in the snow-clad summits of the Cascade Range, it flows eastward to join the Columbia through a valley where the soil has unusual depth and great fertility. The economic importance of the Yakima is enhanced by its easy diversion, in which respect it is in striking contrast to the Columbia, which also crosses the arid portion of the State from north to south, but lies far below the plateaus along its banks.

In no part of the West outside of California can so many kinds of crops be grown on the same acre of land as in the irrigated valleys of central and southern Washington. Alfalfa meadows and prune orchards, hop-fields and vineyards, apples, peaches, and Hamburg grapes, all flourish alike in the open air, and the fields and orchards under the canals present a marvellous contrast to the lightcolored, ashy deserts which surround the watered areas.

As Washington has no rival except California in 
the diversity of its products, it also is second only to California in the value of irrigated land. Nowhere else does unimproved farming land bring so high a price, while prune orchards in full bearing have sold for $\$ 250$ an acre. The complete irrigation of the broad valley of the Yakima requires, however, the construction of large and costly canals, but this development is menaced by uncertainty regarding the fundamental right to use the waters of this State in irrigation. With the beginning of settlement in the interior valleys of the State, the legislature, in 1873 , passed a law for the regulation of irrigation and water rights in the county of Yakima. It was intended to have local application, and to abrogate the riparian doctrine in the part of the State where it has no climatic fitness. The confidence which this legislation gave to investors resulted in a rapid development. Many canals, some of them large and costly works, were taken from the main stream, and smaller canals diverted its tributaries.

These enterprises received a rude shock in 1897 , when litigation over the use of Ahtanum Creek, a tributary of the Yakima, between a riparian proprietor and the owners of one of the ditches, resulted in a decision which closed the ditch in question, and makes the use of water in irrigation largely subject to the voluntary consent of the riparian landowners. A similar controversy has arisen near the town of Walla-Walla, which is surrounded by one of the oldest farming districts 
in the eastern part of the State. In this section irrigation is not a necessity, but it has great value and is being more and more employed in fruit-growing. It has been found that as trees approach maturity there is need of additional moisture in order to secure the largest yield and best quality. In I 897 litigation over the right to use one of the streams near Walla-Walla resulted in an injunction which closed the canal belonging to Dr. Blalock, which was used in the irrigation of an orchard of 640 acres. If some means of averting the results of this ruling had not been found, the results would have been serious; but, in this instance, relief was secured through the purchase of a right to the sewage water of the town of Walla-Walla.

There is at present no public control over streams in Washington, and there can be no effective control until the conflict between the riparian doctrine and that of appropriation has been adjusted. It is the greatest need of the Yakima Valley, and will in time be indispensable on other streams. In Washington, as elsewhere, it is one of the governmental functions which new conditions have postponed but which must ultimately be assumed.

\section{Oregon}

In Oregon irrigation is a matter for the future. So little has been done in this State that its prob- 


\section{IRRIGATION INSTITUTIONS}

lems have not been defined. The riparian doctrine is recognized, but recent decisions have held that appropriators of water for irrigation who divert and use it without protest cannot afterward be interfered with by riparian landowners. 


\section{CHAPTER XIII}

\section{RIPARIAN AND INTERSTATE Rights}

THE doctrine of appropriation grew out of the climatic needs of the arid region, which makes the demand for water on farms remote from the streams as imperative as that of the farms which border them. In addition public policy favors the use of streams on nonriparian lands. The upland areas are better suited to irrigation, and crops can be irrigated with less labor and less water. Locating the irrigated areas in broad compact tracts is economical, and it secures better social and industrial conditions than is possible by restricting irrigation to riparian lands and confining homes to the banks of streams. If no distinction is made between the riparian and non-riparian lands, it is possible to choose the localities best suited to cultivation and to extend greatly the acreage which can be cultivated. Public welfare requires, therefore, that the aristocracy of privilege conferred by the common law on riparian proprietors shall here be abrogated, and in eight States and Territories (Montana, Wyoming, Colorado, Utah, Idaho, Nevada, and the Territories of Arizona and New Mexico) this has been done. 
There is another reason why the rivers of the arid region should not "continue to flow as they have been wont to do from time immemorial." Every acre of land made productive by irrigation robs the stream of a part of its water-supply. As water is now used, about two-thirds of all that is diverted by ditches and canals is taken up by growing crops or absorbed by the air through evaporation. Approximately one-third of the volume diverted returns to the natural channel through waste and seepage. In the future, because of better canals and more skilful irrigators, even less will return. Many streams will in time, therefore, become mere remnants of their former selves. This change in a few instances has already taken place. So little water runs in some of the rivers of southern California that the stream channels are now grown up with underbrush. Reservoirs catch the floods and ditches divert the ordinary flow. It is claimed that the diversion of water in Colorado is causing the bed of the Arkansas in Kansas to be filled with drifting sand. To water many western valleys will involve drying up the streams which flow through them, and this physical fact ought to be faced frankly and honestly. The doctrine of appropriation contemplates using all the water, and if it is to be carried to its logical end, the rights of riparian proprietors on many streams must be encroached upon. If, on the other hand, streams are not to be absorbed, if respect for riparian rights requires that a cer- 
tain volume continue to run in the channel, a limitation should be put on the building of ditches, both as a protection to investors in these works and to prevent the purchase of worthless water rights.

In the eight States and Territories before named, local laws sanction the complete use of the watersupply, but in eight other States (Texas, Kansas, Nebraska, the two Dakotas, Washington, Oregon, and California), which are partly humid and in part arid, it is uncertain how much of any stream may be used in irrigation or what doctrine governs the rights to such use. This uncertainty has come about in a perfectly natural, if not inevitable, manner. One part of each of these States is humid; the other part arid. The humid lands in every case were first settled, and Territorial, if not State, governments were organized before the development of the arid sections began. Nebraska had become a wealthy and populous State before there was any general recognition of the fact that any part of the State needed to be irrigated. Settlement was largely confined to the eastern half, where the common-law doctrine of riparian rights has a climatic fitness. If the riparian doctrine in Washington and Oregon was limited to the region west of the Cascades, nothing but good would result. In both States it has been given a general application which is unfortunate. When the arid sections of these States began to be reclaimed through irrigation, the people directly interested in this work 


\section{IRRIGATION INSTITUTIONS}

recognized the need of a legal right to divert the water which filled their ditches. This was not because of interference from riparian proprietors but as a better protection from interference from other and later appropriators. In none of these States did the dangers of the riparian doctrines seem to have received much consideration from irrigators during the earlier years, nor did the passage of laws recognizing, without limitation, the right to appropriate water seem to have been opposed by the owners of riparian lands. The two doctrines of stream ownership, directly antagonistic in principle, were put in operation without protest or general recognition of what was taking place. In all but two of these States both doctrines were given unlimited force and effect. The riparian doctrine applied to every stream, so did the right to appropriate all the water, and no distinction was made as to whether water appropriated was to be applied to riparian or non-riparian lands. In two States, however, exceptions were made. The first irrigation law in the State of Washington limited the appropriation of water to Yakima County, and in Kansas it applies only to the part of the State west of the 99th meridian.

When the users of water under these two doctrines came in conflict, the courts had to settle the issues created; but as each decision dealt with a particular and often local issue, and had to be governed by the facts submitted by the parties to the litigation, they seldom lay down general principles, 


\section{RIPARIAN AND INTERSTATE RIGHTS}

and are not always consistent with each other. Hence, they do not furnish a definite guide for a general doctrine or a complete basis for the settlement of future controversies. Nevertheless, it is to these decisions, rather than to the statutes, that we must go for light on the nature of water ownership in each of the States where these two doctrines now operate.

In some of the States judicial decisions have so changed the character of the common-law doctrine of riparian rights that its ancient landmarks can no longer be recognized. The owners of riparian lands in California, Washington, and Oregon have practically become privileged appropriators of water. The right rests in the landowner rather than in the land. He can sell or surrender it, and in Oregon it can be taken away by condemnation. In California recent decisions have practically extended the riparian privilege to all of the lands within the drainage basin of a stream instead of restricting it to that of the proprietors who live along its banks. In the State of Washington the owner of arid riparian lands can take water away from non-riparian farms, which have been made productive at great expense, and use it to irrigate his own lands, although doing so reduces the flow of the stream in equal or greater measure.

It would require more than finite intelligence to predict the doctrine which is to ultimately control streams in the States where these conflicts now exist. The final solution will have to take into 
account the rights which have already vested, and the first thing to be done in this matter is to say what these are. It would seem that this is not only legally possible but that it is absolutely necessary.

It does not seem likely that the States which have recognized riparian rights will ever abrogate that doctrine. The sentiment of the humid districts will always be against a change, and this will be reënforced by the conservatism which seeks to retain a time-honored institution and by a growing recognition of the dangers created by the lax laws under which appropriations are claimed and the more lax and imperfect methods by which they are adjudicated. As a choice between limiting rights to riparian lands and making streams the personal property of speculative appropriators, public sentiment will approve the former.

In the arid West, it will not answer to give the riparian lands the sole control of streams, because this will prevent the best and largest development, and because such limitation is not warranted by any element of natural justice. The water which fills the stream does not come from lands owned by riparian proprietors. Its storehouse is in the distant mountains. The snows and rains fall as a rule on public land, and are as much the property of the non-riparian as of the riparian landowner. The districts where streams rise belong chiefly to the government. The preservation of the forests upon which the perennial character of the water- 


\section{RIPARIAN AND INTERSTATE RIGHTS}

supply depends is looked after by the government and paid for by the non-riparian alike with the riparian proprietors. There is no reason why the public should favor either the riparian or nonriparian landowner, but the public is vitally concerned in securing the largest and best use of its valuable resources, and this requires that the best land should be irrigated and water used where it can be diverted to the best advantage and made to produce the largest results.

If riparian rights are to be recognized, they should be made inseparable from riparian lands. If it is good law and good policy to give the present owner of riparian lands a right in the stream, it is equally good law and good policy to protect the future owner of these lands in this right. This cannot be done if riparian rights are held to be transferable. The recognition of the power to sell these rights is contrary to the teachings of experience in either arid or humid countries. Such sales in California have already helped to create monopolies in water, and made it an instrument of speculative extortion not permitted by the worst of the State laws where rights are acquired by appropriation alone.

Every individual right should be defined in some way, and its volume, or the land to which it attaches, determined by some systematic procedure, so that on every stream those interested may know how much of the water-supply is controlled and how much remains to be utilized by others. It 
would seem that a statute to provide for this could be enacted, which would be at least as effective as the slow evolution of a doctrine by piecemeal through court decisions.

The enactment of laws so antagonistic in principle as those which recognize both appropriations and riparian rights to streams has been made easier by mistaken methods of economic legislation. It is the exception rather than the rule to have complex economic problems dealt with by men who have made a study of these questions. While it would seem that one of the first concerns of Western statesmen would be to conserve the most vital resource of Western civilization by laws which would insure that the water-supply should be used on the largest possible area and by the greatest number of people, such has not been the case. Irrigation laws have too often been drafted by those having special interests to serve, and who look no farther than their own personal needs. The owner of a pond in South Dakota, wishing to fill it from a stream, drew an irrigation bill which would allow him to do this and secured its passage by an accommodating legislature, and in this way the entire State was affected by a very troublesome law.

The framing of the irrigation laws of the Northwest Territory of Canada was preceded by a careful investigation of the operation of the irrigation laws of other countries. The provinces of Australia devoted several years to a study of the irriga- 


\section{RIPARIAN AND IN'TERSTATE RIGHTS}

tion codes of other lands before attempting to frame one for their own. The laws were framed by the commissioners who made these investigations, and their conclusions, so far as they relate to the riparian doctrine, have a special significance and value to this country because they deal with the conditions which prevail here and apply to countries having laws and inherited jurisprudence not unlike our own. The Canadian law abrogates riparian rights. The commissioner who framed it explains why this was done, as follows :-

The investigations in this subject had led to the conclusion that the foundation provision necessary in an act of this kind was that riparian rights should be abolished and the Government given a free hand to apportion or distribute the water and control its use in such a way that the greatest good to the greatest number would result therefrom.

The abolition of riparian rights and vesting the absolute control of all water in one strong central authority are the important provisions of the act. In many of the States in the United States riparian rights have been abolished, and title to the water vested in the commonwealth; but there the vacant lands belong to the Federal Government, and it is impossible to so combine the land and water, owing to this divided authority, as to secure the most beneficial results therefrom.

The provisions of our act on the subject of riparian rights will no less have to undergo the test of litigation, but assuming that the decision of the courts will be in favor of the act, there is no doubt that the one central authority, being vested with ownership and control of both the land and the water, should make it possible to so administer the two as to secure the greatest possible benefit to the greatest number. 
In the provinces of Victoria and New South Wales, in Australia, the modifications of the common law are clearly defined by statute. In Victoria the riparian proprietor has the right to use water for domestic purposes and for cattle without any regard to the effect of such use on the riparian proprietors below. That is, they can use water as long as the stream furnishes it, and if such use destroys the stream, those below have no remedy. Riparian proprietors are also required to register their claims, so that every user of water from the stream may know exactly their character. In the province of New South Wales riparian rights are subject to the following restrictions: "The occupier of land on the bank of a river or lake shall have the right to use water for domestic purposes, for the watering of cattle or other stock, or for gardens not exceeding five acres in extent used in connection with the dwelling house."

\section{Interstate Rights}

The need of some adjustment of these two doctrines, or at least of some definite understanding of their respective spheres of influence, is rendered far more important by the conflicts which have arisen over the division of interstate streams. Even under the most favorable conditions, the settlement of interstate water rights will always be perplexing, but they have been complicated in this country by the differences in State irrigation 
laws and by the manner in which State boundaries ignore drainage lines.

From the Alleghanies to the Rockies, the exact location of State boundaries is a matter of small consequence, but it is otherwise in the arid region, broken as it is by lofty, precipitous, and sometimes impassable, mountain barriers. Here boundaries which ignore the influence of mountains and streams are often a source of great inconvenience and economic loss to settlers. Many perplexing questions regarding water rights in irrigation could have been avoided if State boundaries had followed drainage rather than mathematical lines. It would be a great gain to the settlers of northwestern California if the boundary between that State and Nevada had followed the summit of the Sierras. They would then be near their State capital and living in a commonwealth having a climate and productions similar to their own. As it is, they must journey through Nevada and almost past its capital to reach the seat of government in their own State. It would give Nevada control of the sources of its chief river and irrigators a security which they do not now enjoy. The present boundary crosses Lake Tahoe and cuts off the headwaters of the Truckee River. All of the water now goes to Nevada and probably always will, but it is physically possible to turn the lake into California, and so long as there is uncertainty as to how far each State is supreme within its own domain, there will be something 


\section{IRRIGATION INSTITUTIONS}

lacking in the stability of the Nevada irrigator's rights.

The eastern boundary of Idaho skirts the western base of the Teton Mountains. Streams which rise on the western slope of those mountains flow into Idaho, and the settlers along their banks do business in that State. Those who live in Wyoming are separated by a mountain barrier from both the State capital and the county seat of their county. To reach either, they must pass through the county seat of the nearest county in Idaho, make a long and expensive detour, and cross two States. Some of the ditches which irrigate lands in Idaho begin in Wyoming, but the rights to water cannot be determined, because the State water laws are different and there is no jurisdiction across State lines.

In a few instances, rivers are State boundaries. The rights of appropriators on one bank are of a wholly different character from those on the opposite side. Lesser Snake River crosses the boundary between Colorado and Wyoming four times. The ditches which head on the loops in Wyoming have had their rights adjudicated, but the owners of ditches from the loops on the Colorado side of the boundary pay no attention to these priorities.

Bear River rises in Utah, flows into Wyoming, crosses again into Utah, returns to Wyoming, thence flows into Idaho and finally empties into Great Salt Lake in the State where it began. From its source to its mouth, all of the level lands 


\section{RIPARIAN AND INTERSTATE RIGHTS}

along its banks are being irrigated. The appropriations already made are in excess of the water-supply but there is no way of protecting priorities. A change of less than twenty miles in the location of these State boundaries would have put an end to all these perplexities by putting all of the irrigated lands in one State.

There are, however, other water-right questions not so easily solved. The rivers which rise on the eastern slope of the Rocky Mountains flow into humid States before they reach the sea. In this way riparian landowners and the owners of steamboats are interested in the water-supply, and one of the most momentous problems of the future is to determine how these respective interests shall be adjusted. The settlement of rights between appropriators for irrigation from an interstate stream is a perplexing question, but it is the simplest form which interstate water rights assume. On nearly all the important rivers, rights for irrigation are complicated by rights for mills and factories and with the interests of navigation. The North Platte river will illustrate this. It rises in Colorado, crosses the southeast corner of Wyoming, where it is reënforced by tributaries which drain one-fourth of that State; then entering Nebraska on its western border it empties into the Missouri at the eastern boundary. Its headwaters are in a region wholly arid. The country through which it flows and the region it drains in Wyoming is arid, as is the western third of Nebraska, while the eastern 
two-thirds of Nebraska is humid. How, then, are the respective interests of these three commonwealths to be adjusted and how is the stream to be divided? The rights in Colorado have been adjudicated by the State courts. They are already vested and are the personal property of the ditchowners. In Wyoming the rights on the main stream have not been determined, but those of more than a thousand appropriators on the tributaries have been settled by the State board of control. In Nebraska a large number of appropriators' rights have been determined by a State tribunal, while all of the stream is claimed by the riparian proprietors and an organization of millowners has been perfected to contest any use of the river in irrigation. The nature of the rights and the tribunals which determine them are different in each of these three States, yet all three govern the same water-supply. This, however, does not end the possible issues to which the use of this stream in irrigation may give rise. The river is one of the important feeders of the Missouri. The latter is a navigable stream and reënforces the Mississippi, where navigation interests are still more important. The ditches already built will, when used, absorb a large part of the flow and will then only reclaim a small fraction of the lands needing irrigation. The aggregate of the appropriations already declared vested in Colorado, Wyoming, and Nebraska far exceeds the total flow of the stream, but if this water is used, may not 


\section{RIPARIAN AND INTERSTATE RIGHTS}

the claim be made (as it has been made elsewhere) that this use impairs navigation, and give rise to litigation to determine whether the farm of the desert above or the steamboat below is to have first claim on the mountain snows?

The several States have based their authority to supervise the division and use of non-navigable streams within their borders for irrigation and other beneficial purposes on customs recognized by the federal authorities and on a law passed by Congress in $1866,{ }^{1}$ but if the reservation in this law regarding the protection of vested rights requires the irrigator to recompense both navigation and milling interests for all the damage his use of water may cause, it will put an end to irrigation of non-riparian lands, because the natural obstacles are in themselves a sufficient handicap.

The United States Supreme Court has held, in United States $v$. Rio Grande, D. \& I. Co., I74 U.S. 690 , that the rights of navigation on the mouth of a stream may be enforced over the water-supply of its

1 Whenever, by priority of possession, rights to the use of water for mining, agricultural, manufacturing or other purposes, have vested and accrued, and the same are recognized and acknowledged by the local customs, laws and the decisions of courts, the possessors and owners of such vested rights shall be maintained and protected in the same; and the right of way for the construction of ditches and canals for the purposes herein specified is acknowledged and confirmed; but whenever any person, in the construction of any ditch or canal, injures or damages the possession of any settler on the public domain, the party committing such injury or damage shall be liable to the party injured for such injury or damage. 


\section{IRRIGATION INSTITUTIONS}

remotest tributary. In Howell $v$. Johnson, 89 Fed. 556 , the claim of each Western State to exercise exclusive control over the non-navigable streams within its borders has been disputed. In this case the issue was between appropriators of water in Montana and Wyoming, both States where riparian rights have been abrogated by State laws, and where the paramount sovereignty of each State over streams has been affirmed by State statutes and court decisions. The decision is not based on the laws of either State, but chiefly on rights held to attach to the public land, and if it shall be sustained in subsequent decisions cannot fail to have a far-reaching influence on the rights of irrigators as now recognized and established. The grounds on which this ruling is based are set forth in the following extract:-

It is urged that in some way the State of Montana has some right in these waters in Sage Creek or some control over the same. It never purchased them; it never owned them. In support of this view, the court is cited to a great many decisions which apply to navigable rivers and lakes and tide-waters. Here we approach a different subject. There is no claim that Sage Creek is a navigable stream. A State, upon its admission into the Union, acquires by virtue of its sovereign powers the title to the beds of all navigable rivers, lakes and tide-waters within its boundaries, subject, however, to its rights of commerce and navigation. This title gives it, to some extent, a control over the waters of such rivers and lakes, and the power to establish and determine what shall be the riparian rights which shall pertain to those who hold the title to lands bordering on the same. ... When a party has obtained title to property from the National Gov- 
ernment, the State government has no right to destroy that title, except under the power of eminent domain. The State of Montana cannot step in and say, "The right to the water of Sage Creek, which the plaintiff acquired under the laws of Congress, you cannot exercise in this State." This would be the taking of the plaintiff's property from him without due process of law. It is a recognized rule of law that a person who has appropriated water at a certain point in a stream is entitled to have so much of the waters of said stream as he appropriated flow down to him to the point of his diversion. The defendants, according to the allegations in the bill, are violating this rule and should be enjoined.

A suit recently brought in the Supreme Court of the United States - The State of Kansas $v$. The State of Colorado-involves a settlement of the respective rights of the people of these two States to the water of the Arkansas River. This river rises in the Rocky Mountains, and after flowing nearly 300 miles in Colorado, crosses its eastern border into Kansas, where, after traversing the State for 3 Io miles, it enters Oklahoma, finally emptying into the Mississippi on the eastern boundary of Arkansas. The sources of this river are in the arid region; its outlet, in the humid region. At the lower end of the river navigation is the principal interest. At the upper end, the right to use its water in agriculture is of overshadowing importance, and a denial of this right would be a disaster of national importance. Over 300,000 acres of land are irrigated from this river in Colorado. Fourteen water districts have been created, and the water commissioners of those 
districts divide the main stream and its tributaries among I 750 ditches. Over two and one half million dollars have been expended on irrigation works in one of the fourteen water districts, and over a million dollars of private capital has been invested in the construction and improvement of storage works. The soil and climate are well suited to the growing of sugar beets and a number of other products of large acreage value, and great sums of money have been invested in factories for the manufacture of sugar and in other industries dependent on irrigation. The interests which hinge on the right to use this river in irrigation represent, not only immense sums of money, but the prosperity and happiness of a very large number of people.

Western Kansas is also arid. In much of the valley of the Arkansas, crops cannot be grown by the aid of rainfall alone. Large sums of money have been expended in that State in the construction of irrigation canals to divert this river. The canals at Garden City alone are said to have cost over a million dollars. Many small tracts of land are being irrigated by windmills, which pump water from what is known as the underflow of this river.

Discussion as to the respective rights to this river, in these two States, has been going on for several years. Failure to reach an understanding has culminated in this suit in which Kansas, in its own behalf and in behalf of the people of that State, asks that Colorado be restrained from any further diversion of the stream or any new use 
which would work an injury to the people of Kansas. In this complaint it is stated that, while the rainfall of the western part of the Arkansas Valley in Kansas is not sufficient to mature cultivated crops, for many years crops were successfully grown because the river was not restricted to its surface channel but spread out, through the porous subsoil which underlies the visible stream, in a broad sheet coextensive with the width of the valley, and that this underground portion of the river, called the underflow, not only furnished the needed moisture for crops but was a convenient source of supply for water for domestic purposes and watering stock. It is held in this complaint that the water taken from the river in Colorado has greatly reduced both the surface and underflow, reduced the taxable and productive value of a large part of the State, and caused much personal hardship and suffering; that, unless some action is taken to prevent the further storage of water in Colorado and extending its use to new lands, it will deprive the farmers in Kansas of both their surface and subterranean water-supplies and thus cause this portion of the State to become an arid desert.

It would seem that some sort of interstate regulation is required. Nothing can be more unjust or more uneconomic than the building of ditches in excess of the capacity of a stream to fill them. Nothing is gained by extending the irrigated area in one section, when an equal number of acres are 


\section{IRRIGATION INSTITUTIONS}

returned to aridity in another. Every acre brought under cultivation beyond what the flow of a stream will serve means simply a loss of money in ditches, added burdens to the State in supervision, and controversies and loss to farmers. There ought, therefore, to be some limitation placed on the diversion of water from streams, as nothing is gained by the building of more ditches than a stream can fill, and nothing does more to cause losses to farmers and contests between the holders of water rights.

The claim of Colorado to the complete use of this river is based upon her right as a sovereign and independent State to make the largest and best use of her resources in any way which will increase her revenue or improve the moral or material well-being of her citizens, without regard to its effect on the prosperity of States or the citizens of States below.

The court has declined to pass on the issues raised without a better understanding of the facts. The following paragraph from the opinion gives the reasons for its action:-

Sitting, as it were, as an international, as well as a domestic tribunal, we apply Federal law, State law, and International law, as the exigencies of the particular case may demand, and we are unwilling, in this case, to proceed on the mere technical admissions made by the demurrer. Nor do we regard it as necessary, whatever imperfections a close analysis of the pending bill may disclose, to compel its amendment at this stage of the litigation. We think proof should be made as to whether Colorado is herself actually 


\section{RIPARIAN AND INTERSTATE RIGHTS}

threatened to wholly exhaust the flow of the Arkansas River in Kansas; whether what is described in the bill as the "underflow" is a subterranean stream flowing in a known and defined channel, and not merely water percolating through the strata below; whether certain persons, firms and corporations in Colorado must be made parties hereto; what lands in Kansas are actually situated on the banks of the river, and what, either in Colorado or Kansas, are absolutely dependent on water therefrom; the extent of the watershed or the drainage area of the Arkansas River; the possibilities of the maintenance of a sustained flow through the control of flood waters; in short, the circumstances, a variation in which might induce the court to either grant, modify, or deny the relief sought or any part thereof.

The result is that in view of the intricate questions arising on the record, we are constrained to forbear proceeding until all the facts are before us on the evidence.

Speaking without reference to the issue before the court the following facts regarding the changes in the flow of streams wrought by settlement seem to be well established. Its effect on the watersupply of the whole country has been injurious. It has widened the limits between floods and drouth: the fluctuation between high and low water has become greater than it was formerly, not alone in the mountain States, but in the Mississippi Valley as well. It has its causes in the burning and cutting of timber on the headwaters of streams, the removal of vegetation, and the trampling of live stock on the lower lands. In the Rocky Mountains the tie-chopper and the fires of hunters and mountain campers have made great inroads on the forests which clothed their slopes and have bared 


\section{IRRIGATION INSTITUTIONS}

the rocks which were formerly covered by the leaves and weeds which had fallen for centuries and which acted as a sponge in holding the rains and snows which fell upon them. Below these mountain summits and in the foothills, range flocks and herds have eaten off the grass and trampled down the soil. Forests, weeds, and grass are all great conservers of moisture. Where once it required weeks for the rains and snows to reach the channels of streams, they now flow down in a few days or a few hours. The result is that the mountain springs and the mountain rivulets dry up far more rapidly than in former years, and the great rivers below suffer in turn. The lessening of the water-supply in midsummer, due to these causes, is a well-known fact in all the States of the Mississippi Valley. The causes which produced it are operating in the mountains and are producing the same results in the rivers of the arid region.

Instead of aggravating this tendency, irrigation lessens it, and is thereby a benefit to both the agricultural and navigation interests on the lower reaches of these rivers. The diversion of flood waters works no injury to any interest below. Irrigation in the mountain States works one important benefit to the arid and semi-arid States lying to the east. It covers the hot, treeless plains with foliage and vegetation. The spreading of water over large areas cools the atmosphere, increases humidity, and gives better conditions for plant growth. It is a well-known law that moisture is 
never condensed where it is formed. The water evaporated from the irrigated fields of Colorado is nearly all carried toward Kansas and other States to the east, because that is the prevailing direction of winds. While it may not be possible to measure the increase in humidity, that irrigation has such local influence is well known. Before it began, dews were not known in Colorado or Wyoming. They are found now in every irrigated valley. If there has been no gain, irrigation has at least corrected an injurious tendency in another direction. It mitigates the dryness caused by the destruction of forests and vegetation on the mountains.

$U p$ to a certain limit irrigation on the headwaters of a river is a benefit to the users of water below. About one-third of the water diverted returns to the stream as waste and seepage. The water diverted during the flood season which returns as seepage comes back slowly and helps swell the stream when it is low and water is most needed. The exact time of the return varies, of course, with the location of the lands irrigated and with the character of the soil, but in a general way, the effect of the diversion of floods in irrigation is to equalize the flow of rivers. They carry less water when high, and more water when low. Some rivers leaving the eastern slope of the Rocky Mountains, which formerly ran dry every year, now have a perennial flow, and on others, the point at which they each year become dry is travelling eastward rather than westward. 
$\mathrm{Up}$ to a certain limit, the storage of water also tends to equalize the flow of streams. Reservoirs are filled when there is an abundance, and the water is turned out when there is a scarcity. Hence, the people who live along streams, below where the stored water is used, derive an indirect benefit from the increased seepage thereby created. There is, however, a limit beyond which irrigation on any stream does not improve the supply of those living below. If the irrigated valley is long enough, and the irrigated district broad enough, the ultimate absorption of the water-supply is inevitable.

In the interests of truth and justice, and to aid in establishing precedents which will permit the best and largest use of Western resources, it is in the highest degree desirable that all the facts which will throw light on these questions shall be gathered and presented to the whole country, and be fully understood by the tribunal which must ultimately pass upon this issue. If it shall be held that each State is supreme within its own boundaries, and can provide for the use by its own citizens of the entire water-supply of interstate streams, it will, of course, put an end to further litigation over interstate questions; but this does not lessen the necessity or diminish the value of securing the facts regarding the influence of irrigation on the flow of streams and on the rights of other appropriators of water or riparian proprietors below. On the other hand, if it shall be held that those 
who have first used water on the lower side of a State boundary are entitled to protection in that use, and that priority of appropriation shall be enforced across State lines, then the first step toward legislation for such protection is a correct understanding of the facts. At present neither the rights of riparian proprietors nor the interests of navigation are clearly defined. Both have such vital relation to the stability of investments in irrigation works that further legislation on this question will in time be inevitable. The number of streams on which these questions must be dealt with, the extent of the territory involved, the range and intricate character of the physical facts, render it desirable that they should be studied by trained and impartial experts, rather than that the gathering of this information should be left to the litigants in cases brought before the United States Supreme Court. 


\section{CHAPTER XIV}

Methods and Measures neEded for Future DEVELOPMENT

THE rapid construction of irrigation works which began in 1870 continued for twenty years. Its interruption at the end of that time was due to a variety of causes, some of which were in no way related to the success or failure of works previously completed. Many of the largest and costliest canals had been built with English and Scotch capital; the failure of the Baring Brothers in 1889 cut off further investment from that source. The disastrous losses of range cattle in the winter of I 886-1 887 , due to overstocking the range, followed as it was by the low prices for beef, bankrupted many of the individuals and firms engaged in this industry and discouraged the further building of ditches as a means of securing control of water fronts. The years of low prices which followed the panic of 1893 put an end to immigration from the East. Farmers who were barely able to pay expenses in a kind of agriculture they understood and under climatic conditions which were familiar, had neither the means nor the courage to attempt the reclamation of unimproved Western lands under conditions which were untried and by methods 
both strange and new. The shrinkage of farm values in the East kept the owners of Eastern farms at home. They could sell only at a ruinous sacrifice, hence they waited for better times. The owners of ditches built in the later eighties had a long and costly wait for settlers after the panic of I 893 began, and the delay in settlement brought in its turn a shrinkage in the value of irrigation works which discouraged capitalists from attempting to build others.

There were other influences unfavorable to irrigation development which were the direct outgrowth of mistaken policies. The experiences of ditch companies which had attempted to water large areas of public land showed that projects of this character could not be made profitable until the land laws had been reformed in such a way as to make speculative filings impossible. The Carey Act, passed in 1894, opened the way for this and secured the construction of a number of important works in Wyoming and Idaho, but the general financial distress which prevailed was too great to be overcome. The mismanagement of irrigation districts under the Wright Law in California, and the business controversies which grew out of this, brought discredit upon this form of coöperation, although the correctness of its principle has been very generally recognized. In other States the loose methods of appropriating water and the abuses which grew out of the recognition of surplus or speculative rights gave rise to costly 


\section{IRRIGATION INSTITUTIONS}

and harassing litigation, which added a large and continuous item of expense to the legitimate cost of irrigation, and presented such a serious menace to the stability of investments in irrigation properties that it has both hampered enterprise and worked grievous injustice to users of water.

The combined effect of all these influences has been to make the years from 1890 to the present a period of adjustment. From 1870 to 1890 ditch building outran settlement. From r 890 to the present the West has been chiefly engaged in putting these canals into use. Material progress, while not so rapid as before, has been continuous and of a healthy character.

When the irrigation of the arid West first began its tendencies were generally selfish and largely speculative. Men thought only of acquiring ownership of the streams and getting possession of all the land possible; in other words, of getting possession of the country, not to use, but to sell again when the user appeared. In one sense, the tendencies were destructive. Irrigation is not suited to the bonanza farm, and speculative land filings, under which large tracts have passed to one owner, have done much to retard the best development of the West, as well as to restrict the opportunities of the really worthy home-seeker. The wholesale surrender of streams to speculative appropriators did little to promote the construction of needed irrigation works, but it did place a mortgage on those who were to use them afterward. 
Until recently the relation of irrigation to the public welfare has received scant consideration. One can search the political platforms of the arid States for the past quarter of a century without finding more than an occasional appeal for Federal aid in material development. The vital issues growing out of the extravagant grants of streams and the dangers of water monopoly thereby created apparently received no thought. There is every reason to be encouraged with the changes of public sentiment now taking place. These dangers, so ably presented by the late Major John W. Powell in his "Lands of the Arid Region," have proven to be real, and his enlightened recommendations have begun to bear fruit. His recommendations regarding the union of land and water have been reënforced by the facts presented in the recent reports of the Irrigation Investigations of the United States Department of Agriculture. It is a significant and encouraging fact that nearly every State engineer in the arid States has been an active and effective worker against the influence of selfishness in acquiring control of the water resources of the West, and for placing public welfare above private interests in the enforcement of State laws. The purposes of the West at present are more patriotic and intelligent. It is beginning to be realized that the waters of Western rivers are a great public resource which must be placed under public control in order to protect the public welfare. In order to do this, 
there must be reforms in irrigation laws and an assertion of a larger measure of public authority than has hitherto been thought necessary or desirable.

For the first time since the settlement of the West began, irrigation is not regarded as a local issue. The East has at last become awakened to the increase in national wealth and power which will come from the settlement of the irrigable arid lands. Our recent achievements in war and commerce in the Pacific have awakened a new interest in the undeveloped region which separates the settled and populous humid States from the $\mathrm{Pa}$ cific coast, and has stimulated a desire for its improvement. In response to this feeling, the first session of the Fifty-seventh Congress passed an act which sets aside the proceeds of the sales of public lands as a fund for the construction of public irrigation works. This policy was recommended in the President's message in an argument of great clearness and power, and the passage of the bill marks the beginning of a new era in Western development and in governmental policies regarding irrigation. It is, therefore, an appropriate standpoint from which to review the methods and measures needed to secure the largest and best use of Western agricultural resources and for discussing the intricate and complex questions which must be dealt with as a part of this development.

The first thing needed is a clear insight into the existing situation. We need to know the nature of 
the rights already vested and the tendencies of the customs established in order to understand rightly the limitations which are placed on future action and the direction which future development should take. It must be borne in mind that in dealing with irrigation we are not confronting a new issue.

In the last third of the nineteenth century the arid West became one of the greatest irrigated districts on the globe. In mileage of ditches and in acres of land irrigated it surpasses any country of Europe or Africa and is second only to India and China in Asia. As has been before stated, in this growth construction outran settlement, and land and water filings largely exceeded either the cultivation of the soil or the use of streams. The canals already built will serve twice as many acres of land as are now being farmed under them. The ditches of Idaho now water 560,000 acres; 1,500,000 acres lie below and await irrigation from them. The canals and ditches of Colorado water about 2,000,000 acres, but they cover 3,000,000 acres. Less than half of the land under ditches in Wyoming and Nebraska is being cultivated. Of the 350,000 acres under canals in Salt River Valley, Arizona, only 125,000 acres are being farmed. The same conditions exist in other arid States and Territories. In many sections of the West, therefore, the first need is not more canals but more settlers to cultivate the lands already covered by canals. Great landed properties need to be broken into small 


\section{IRRIGATION INSTITUTIONS}

farms; meadows of native hay and sage-brush pastures to be transformed into cultivated fields.

One reason why this change is taking place slowly is uncertainty over water titles. The building of an irrigation ditch too often means for its owners the beginning of a large and continuous outlay in controversies over water rights. Farmers who wish to live in peace and who fear the outcome of these controversies prefer to wait until they have been settled. They will neither rent water from the ditch company nor purchase water rights from it, nor make the expenditures required to bring the irrigable lands under cultivation. As a result, both ditches and lands continue unused or only partly used. California has many examples of this form of arrested development. Irrigated land along Cache Creek is worth from two to three times as much as land not irrigated, but the greater part of the water-supply runs to waste. Ditches which were built years ago are unused and abandoned because of ruinous litigation over who owns the stream. The Central Canal from the Sacramento River, which was begun many years ago, remains unfinished, although $\$ 576,000$ has been expended upon it and it is capable of watering 150,000 acres of very valuable land. The benefits which would come from its completion would be far greater than the outlay required, but nothing is done because no one knows what sort of legal obstructions would be encountered if the attempt to use the river were 
made. California is not alone in this respect. The failure to provide for a final and definite establishment of water titles, and the fact that the complex issues regarding appropriations must be fought out in the courts, have, in many cases, produced a condition of virtual anarchy which has stopped the growth of communities and too often caused the weak to lose the results of years of effort, regardless of their merits. The failure, from a financial and industrial standpoint, of scores of irrigation works has been due to inadequate or misfit water laws.

Another reason why many ditches remain unused has been explained in the chapter on land laws. Much of the public domain has been secured by parties who do not care to farm it but who hold it for the rise in values due to the growth of population and improvements made by others. Neither ditch companies nor settlers can afford to pay the prices asked for these holdings, which, under a proper system of land laws, would have been reserved for actual cultivators of the soil.

A further reason for delay in settlement is the unfairness of some of the earlier water contracts, under which canal companies have tried to dispose of water. These have been discussed in a preceding chapter. A reform in these contracts, so that all the burdens of the uncertainties of climate and accidents will not be placed on the farmer, will do much to create a better feeling toward canal companies and help them to secure settlers. 


\section{IRRIGATION INSTITUTIONS}

Perhaps the chief reason for the slowness of settlement is one which is not due to inadequate laws or mistaken policies, but to the nature of Western conditions. Settlement in remote and sparsely peopled localities has been delayed because of the hardships and expense involved in establishing homes. In such localities the cost of living in the first years is great. Interest rates are high; implements and material of all kinds are expensive because they have to be transported long distances. The settler must build a house and fences, remove the sage-brush, and grade the land for the distribution of water, and lay out and construct laterals to lead it over the fields. It is a rare exception when the first crop grown on arid land is a success. Ditches are apt to break, the fields are rarely in condition for the proper distribution of water, and under the best conditions it is hard to keep crops growing on a soil and subsoil which has been parched for centuries. When to all of these expenditures there is added a large outlay for water rights, it brings the cost of an unimproved farm on the frontier up to that of improved land in the populous East. These obstacles are too serious to be overcome by the efforts of colonization agents and the literature of ditch companies. Men of limited means are not able to establish themselves; men who have money enough to succeed do not care to incur the hardships of pioneer life or the risks of a new industry. They can enjoy landed independence 
without it. The industry is not fitted, therefore, to make homes for poor men, or to furnishing immediate returns on the capital invested in irrigation works. These are among the reasons for the construction of irrigation works by the government.

The largest bodies of irrigable public land and the greatest opportunities for creating homes on the public domain are to be found along the large rivers in the northern and central part of the arid region. Among these, the Big Horn, the Missouri, the Yellowstone, the Snake, the Grand, and the Green are notable examples, although not the only ones. In the valleys of these rivers, large areas await reclamation and settlement. The soil is fertile, the climate healthful and attractive, and all the conditions are favorable except the great cost of works for diverting these rivers. Experience has shown that it is a losing investment for private capital to build these costly works, not because they do not ultimately pay, but because of the long delay in securing settlers for the lands and in bringing them under cultivation. Moreover, the character of these works makes them an appropriate field for the expenditure of public funds, and government aid in turn makes it possible to continue the liberal policy of the government in the disposal of its public lands.

The immense areas which these dams and canals will dominate renders it desirable that they should be under public supervision. The welfare 


\section{IRRIGATION INSTITUTIONS}

of thousands of homes will be governed by their success. Their construction will open up large areas of land now practically worthless, and will afford renewed opportunities to home-seekers. It is believed that these opportunities should be given as far as possible to men of limited means, men who have habits of industry and economy and but little else with which to establish themselves. Such men cannot, however, make needed improvements and repay all the outlay required for these works. If the giving of free homes, such as were secured in the disposal of the public lands of Iowa and Kansas, is to be continued, the water from these large canals should be furnished to settlers, not at what it costs to build them, but at what settlers can afford to pay. The best plan would be to furnish water free of cost during the years when the outlay in other directions is greatest and leave the period of repayment to the future. Private capital cannot afford to do this. The government can, because of the benefits which come from the increase in taxable and productive wealth in which private enterprises do not share.

Much of the land under completed ditches is not being farmed, because of lack of water. As a rule, this shortage is not due to insufficient supply but to its unfavorable distribution. Streams which have an abundance in May become almost dry in July and August. The average flow of the Arkansas River in June, I898, was 2428 cubic 
feet per second. In August this had dropped to 326 cubic feet per second. One season, irrigators on the North Platte had 34 times as much water in June as in August. In the first month they had far more than they could use; in the second, more than half of the ditches were empty. For one day in May, I901, the Poudre River carried 5000 cubic feet per second. It not only filled all the ditches, but all its channel would carry ran to waste. On July 6 its flow had fallen to 63I cubic feet per second. One of the ditches from this river could have diverted and utilized the entire flow.

With a better understanding of the flow of streams and of the needs of crops grown under irrigation, it has come to be realized that the regulation of the flow of Western rivers is almost as important as the building of canals to divert their waters. Farmers have learned that dependence on a canal which is empty half of the season is worse than waiting for rain in a humid climate, and it has also come to be understood that irrigation is an insurance against drouth only when cultivation is restricted to the area which can be watered when the supply is least. To depend wholly on the natural flow of streams will permit of the best use of only a small part of the watersupply, because it leaves the flood waters to run to waste.

Before these facts were understood, the efforts to utilize the high water-supply of the early spring 
led to the construction of more ditches than can be filled and the attempt to irrigate more land than can be profitably or safely farmed without storage. The scanty snowfall in the Rocky Mountains in the winter of I90I-I902 has brought this condition of affairs forcibly to the attention of irrigators along the entire eastern slope of the Rocky Mountains. Not only was a large percentage of the crops along these streams ruined by drouth, but many of the cities and towns along their banks found it difficult to obtain sufficient water for domestic uses. During more than half of the irrigation period, the city of Denver had to rely on stored water for a large part of its domestic supply. If it had depended wholly on the natural flow of the stream, there would have been practically nothing left in the South Platte River for the use of irrigators. As it was, many of the largest and costliest ditches were without water during the greater part of the season and thousands of acres of crops could not be brought to maturity.

In recent years, almost as much money has been invested in storage works as in ditches, and many important reservoirs have been built by private capital. One of the largest in the West was completed in Wyoming in I9or. In the two years ending December I, I900, the State engineer of Colorado issued permits for the construction of 147 storage works and the State engineer of Wyoming issued 77 of these permits. A private reservoir on 
the Pecos River in New Mexico covers 8000 acres. The construction of storage works has been one of the most profitable features of recent irrigation progress in Utah. In the latter State, nearly all the surplus water of the streams first used in irrigation is now being stored and put to use. The construction of these works has in most instances proven exceedingly profitable as an investment, while the benefits derived therefrom by farmers can scarcely be appreciated by the outside world. Statistics show that in many instances the money value of the crops grown on irrigated land has been increased by the construction of reservoirs from 50 to 60 per cent, and it has equally desirable results in other directions. In many places where settlers have to depend upon the natural flow of streams, they cannot plant shade or fruit trees because of a failure of the water-supply in midsummer. Where trees have been planted, they have died for lack of moisture. In such locations, reservoirs have not only enlarged the boundaries of irrigation and increased the yield and value of crops, but have worked a transformation in the comfort and beauty of homes. Where they are located so as not to menace the lives or property of people living below them, or do not interfere with the natural flow of streams, there does not seem to be any reason why this form of private enterprise should not be encouraged, or why it may not accomplish great results without governmental aid. 


\section{IRRIGATION INSTITUTIONS}

There is, however, one class of storage works which have such relation to the public welfare that they should be built under public supervision and perpetually maintained and operated as public works. These are reservoirs located in the channels of running streams. Such reservoirs not only interrupt the natural flow, but require that the stored water and the water claimed by appropriators under existing canals be mingled together in its transit from the place of storage to the place of use. The division of the water of a river among those having rights thereto is always a difficult matter. Where only the natural flow is involved, the constant fluctuations in volume and the varying needs of irrigators render the task of the one responsible for this division a complicated and difficult one. Experience has shown, however, that when to the natural flow there is added a stored supply, the difficulties of those charged with its division are largely increased.

The streams on which storage works are constructed are also the ones on which protection of existing rights is of unusual importance. These works are not built until there is a shortage of water. So long as the stream will serve the needs of irrigators, it is cheaper to take water directly from it than to store it, and the subject of reservoirs is neglected until some one suffers from drouth. If, therefore, through a failure to protect rights, some one receives more water than he is entitled to, the surplus has to be taken from some 
one to whom it belongs and who is in need of it. The holders of rights to the natural flow of the stream are disposed, therefore, to scrutinize closely everything which interferes with its division. The construction of a reservoir in the channel of a stream inevitably causes such interference, because all the water which comes down from the mountains has to flow into it and rights can only be protected by such regulation as will insure that as much water runs out as flows in. Where these storage works are owned by private parties, there is great temptation in times of scarcity to hold back a part of the supply, and there is equally great anxiety and fear on the part of irrigators not interested in the reservoir that this will be done. As reservoirs are frequently located in mountain districts remote from the lands irrigated, farmers cannot see what is taking place, and when there is not water enough to fill their ditches the reservoir is apt to be held responsible for the shortage and to become a prolific source of discord. Some of these private reservoirs have already become public nuisances because of the troubles which they have created over the division of water.

The true function of reservoirs is to act as regulators; to hold back the water which would otherwise run to waste, when it is not needed, and supply it to irrigators in times of scarcity. When this is done, the stored water will supplement that which can be taken by direct diversion. With some irrigators the natural flow will supply nearly all 


\section{IRRIGATION INSTITUTIONS}

their needs; stored water will only be required for a brief period, - perhaps for a week, perhaps only for a single day. Others with later rights in the stream will have to draw more largely on the stored supply, but none need rely entirely upon it if streams are used to the best advantage.

When President Roosevelt said in his first message that the "water from these reservoirs should be turned freely into the channels in dry seasons, to take the same course under the same laws as the natural flow," he announced the correct economic policy. To carry it out requires public reservoirs, but the value of public reservoirs hinges largely on the faithfulness with which the policy which justifies their existence is carried out. In order to deliver stored water to the proper ditches and prevent its being stolen by appropriators who have no right to it, public control of streams is a necessity. Controversies and physical conflicts always arise where such supervision is lacking. Even where these reservoirs are built as private works, the public has to supervise the distribution, and in the end it makes this easier, simpler, and far more satisfactory to have the public own and operate the reservoirs.

All those who believe that the only right to streams which should be recognized is the right of use, object to private reservoirs located in the channels of streams. Whoever stores water as a private enterprise must in the nature of things own the stored water. But if these works are built by 
the public, then the doctrine of public ownership can be maintained over the stored supply as well as over the natural stream, and conflicts over complete public control be averted.

The appropriation of funds to construct public storage works has given rise to some discussion as to whether public reservoirs should supply water to private lands, and some have urged that the watersupply thus rendered available should be applied exclusively to public land. To do this, however, would be a serious economic error. On many streams all the water which can be stored is needed by the land under existing ditches and in private ownership. The settlers on these lands were many of them induced to locate and make improvements by the abundance of water carried by streams in the flood season. Subsequent experience has shown that it is the low-water and not the high-water flow which determines the area which can be safely brought under cultivation, and many of the farms which have been improved are now either not being cultivated at all or are being farmed under discouraging conditions. Their owners have been encouraged to continue by the hope of an increased water-supply through the storage of floods either through private enterprise or public aid, but if the public construction of reservoirs shall divert the stored water to new lands, it will not only afford them no relief but, by exhausting the reserve supply, will take away all hope of securing it in the future. The carrying out of 
such a policy would be both unjust and uneconomic. It would rob one settler in order to provide for another; it would return one acre to aridity in order to render another fertile; it would involve a large outlay in building canals to reach new lands and condemn the canals already built to remain unused or only partly used.

There is greater need of storage works to supply private than public lands, because wherever reservoirs are desired the greater part of the irrigable land has passed into private ownership. The large bodies of irrigable public land still awaiting reclamation are located along the great rivers of the West, where diversion and not storage works are the first necessity; but where there is a demand for reservoirs, the ditches already built and the lands now in private ownership will, in nearly every instance, require all the water which can be made available.

There is practically no irrigable public land in California. All the best land is in private hands. The same is true of Kansas and in a slightly less degree of Nebraska. When the lands under ditches now built have been irrigated, there will be little water remaining for public land from the streams which flow eastward from the Rocky Mountains in Wyoming and Colorado. All of the irrigable lands in Utah along the streams flowing into Great Salt Lake have passed into private ownership. The situation in Salt River Valley, Arizona, has already been referred to, and similar 
conditions prevail on nearly every stream where irrigation has assumed enough importance to make reservoirs a live issue.

While in most of the arid States the government owns a large part of the land, it has disposed of the greater part of its water fronts. There are many causes for this. The need of a watersupply has limited settlement to the vicinity of streams. As has been explained in a preceding chapter, water fronts are sought for by range stockmen as eagerly as by irrigators, and they have acquired them with greater expedition and in larger areas. Three of the transcontinental railways received grants of every alternate section of land for 20 or 40 miles on either side of their tracks. These railway lines have, wherever possible, followed streams, and these grants include half of the land along the valleys of such rivers as the Yellowstone, the Yakima, the Humboldt, the Truckee, the Platte, and many others. The arid States have received grants of sections 16 and 36 , and in addition have had special donations which could be located wherever the States chose. A large percentage of this land has also been located along streams. In one way and another, therefore, the greater part of the irrigable land, outside of the valleys of a few large rivers, has passed into private, corporate, or State ownership, and Federal aid, so far as reservoirs are concerned, will have a very limited influence on the irrigation of public land. 


\section{IRRIGATION INSTITUTIONS}

The paramount need of the West is relief from some of the evils of the haphazard development of the past, and for the creation of conditions which will furnish an adequate foundation for growth in the future.

Foremost among these is a common agreement regarding the nature of titles to water. It must be settled whether rights are to be limited to needed and beneficial use, or streams are to be owned as personal property. It must be settled whether the common-law doctrine of riparian rights when recognized is to be maintained in its original form, or be modified to meet Western conditions. ${ }^{1}$ On many rivers the rights already declared to be vested amount to more than the whole volume. Until it is known whether these mistakes are to be perpetuated, future diversion

${ }^{1}$ If it be the unalterable law of this State that an owner of riparian land may, as at common law, prevent any one above him from taking any water out of the stream for beneficial use, merely that the stream shall flow past his place undiminished in quantity, and whether such riparian owner can put the water to a beneficial use on his land or not, then no legislation that we may suggest, or the Legislature enact, will materially relieve the situation. If that be the law, and it cannot be changed or modified, there is probably no water in any stream in the State that can be legally appropriated, and the right to the use of water that has been appropriated heretofore has only been acquired by the sufferance of riparian owners or their neglect to assert their rights. The enforcement of such a law would be disastrous in the extreme. The majority of the Commission do not believe, if this is the law of the State, as declared by the Supreme Court, that it cannot be changed by the Legislature. - (From report of Irrigation Commission to Water and Forest Association of California.) 
or storage of water will be uncertain and hazardous.

The idea of private ownership of water apart from land cannot prevail without creating institutions essentially feudal in character. A water lord is even more undesirable than a landlord as a dominant element in society, and a proposition for turning over all the land to a private monopoly and making tenants of those who have their homes upon it could not hope to command popular support, but the idea of private ownership of water, amounting to a virtual monopoly of this vital element, has been permitted to grow up in the West. It has no place in the irrigation laws of other enlightened countries, and in ours should give place to a more enlightened conception.

The doctrine that air, water, and sunshine are gifts from God should not be lightly set aside even in arid lands. There is need for adequate protection for investments in canals and ditches, but this can be afforded without having the water they carry become private property or the stream itself become subject to private ownership. The growth and danger of monopolies in oil, copper, coal, and iron afford a warning of the greater danger of permitting monopolies in water. The growing belief in the public ownership of public utilities applies especially to water, that most essential of all utilities.

In monarchies streams belong to the crown, and in the early history of irrigation in Italy and other parts of Europe, favorites of the rulers were re- 


\section{IRRIGATION INSTITUTIONS}

warded with grants of streams. But in a republic they belong to the people, and ought forever to be kept as public property for the benefit of all who use them, and for them alone, such use to be under public supervision and control.

The only right to water which should be recognized in an arid land is the right of use, and even this must be restricted to beneficial and economical use in order that the water-supply may serve the needs of the largest possible number of people. Ownership of water should be vested, not in companies or individuals, but in the land itself. When water rights are attached to land, the needs of crops are always a sure measure of beneficial use. When rights are made personal property, beneficial use becomes simply a legal fiction. Attaching rights to land divides the control of streams like the ownership of land among a multitude of proprietors. Reservoirs and canals are then like the streets of a town, serving a public purpose. Water monopoly is impossible without land monopoly and no other abuse is fostered by it. Years of painful experience have abundantly proven that peaceful and orderly development cannot be realized except as water and land are forever united in one ownership. ${ }^{1}$ The adoption of this principle in

${ }^{1}$ In the arid States the only right to water which should be recognized is that of use. In irrigation this right should attach to the land reclaimed and be inseparable therefrom. Granting perpetual water rights to others than users, without compensation to the public, is open to all the objections which apply to giving away 
Wyoming and Nebraska and its enforcement by the State boards of control has been attended with the best results. If it can be maintained and extended to the other States, it will mark an economic reform of the highest significance in the life of the West.

These limitations on water rights would, it is believed, benefit the owners of canals as greatly as the cultivators of irrigated land. The doctrine of

perpetual franchises to the public utilities of cities. - (President Roosevelt's Message to Congress, December 3, 1901.)

A recognition of the danger of allowing water to be monopolized without regard to the land has led a commission appointed to inquire into California irrigation to declare that " as a matter of public policy it is desirable that the land and water be joined never to be cut asunder; that the farmers should enjoy in perpetuity the use of the water necessary for the irrigation of their respective lands; that when the land is sold the right to water shall also be sold with it, and that neither shall be sold separately." - (Australian Report on American Irrigation.)

Italian experience, French experience, and Spanish experience, all go to show that the interests to be studied in relation to irrigation schemes are so many and so various, and so intimately bound up with the public welfare, that State control is imperatively necessary, and that for the protection of its citizens no monopoly can be permitted which would separate property in water from property in the land to which it is applied. - (Fourth Progress Report, Royal Commission on Water Supply, Victoria, Australia.)

European experience shows ... that where waters belonging to the State are farmed and relet by private individuals water rights are a constant source of gross injustice and endless litigation. The consequence of these interminable vexations is that the poorer or more peaceably disposed landholder is obliged to sell his possessions to a richer or more litigious proprietor, and the whole district gradually passes into the hands of a single holder. - (G. P. Marsh, formerly United States minister to Italy.) 
personal ownership of water has made those who have appropriated it to rent or sell, trustees or agents for users, and thrust on them all of the expense of fighting rival appropriators in the fields and in the courts. It incites every irrigator to rebellion because he feels that the doctrine which gives the stream to the man who diverts it, and denies all rights to the one who uses it, makes him the victim of an unjust discrimination.

So long as ditch-owners are the appropriators of water they have to maintain a dual conflict. They must strive with other appropriators for control of the stream and with their customers over the quantity and price of the water they furnish. On the other hand, where ditches are made carriers of water and rights in streams attach to the land, the burden of the struggle over a fair division does not fall, as it now does, solely on the owners of canals. The farmer thus ceases to look to his water contract with a company, but to the laws of the State for protection in times of shortage.

Where appropriations attach to land, canal owners have no responsibility except to deliver what comes to the head-gate. For this service they are entitled to fair compensation, and they come nearer receiving it in States where the farmer has to protect his own water right than they do in States where the ditch-owner is the appropriator and rates are fixed by boards of supervisors and county commissioners under conditions which make practical confiscation of investments more than possible. 
Whatever may be the opportunities of private ownership of water in the future, it has not thus far in this country worked to the benefit of ditch companies. On the contrary, it is believed to be the greatest evil with which they have to contend. It has been a potent source of hostile public sentiment and the origin of both expensive litigation and retributive legislation.

There is the same need for public control over streams that there is for government control over public land. There is the same need for the State engineer's office in every arid State to direct the diversion of streams that there is for land offices to supervise filings on public lands. We cannot go on in the future as we have in the past, leaving water to be filed upon without limit, used without definite regulation, and leaving titles to its future ownership to be settled in the courts by ordinary suits at law.

The experience of every arid State has shown that trouble always results when it is left to rival users to determine the nature of their rights. Irrigation more than all other industries demands public supervision and control. Every drop of water entering a ditch, every drop escaping at the end of a canal, is a matter of public concern. The public must determine through constitutions and statutes the nature of water ownership. The public must establish means for the measurement of streams and for ascertaining how much water may be taken for each acre of land under the principle of benefi- 


\section{IRRIGATION INSTITUTIONS}

cial use. The public must see that justice is done in the distribution of water among those who have properly established their claims to it. We have thoroughly tried leaving all these to private initiative and management and along with magnificent material progress we have reaped a large crop of deplorable results. In order to have this control just and effective, it must be administered by men who have made a special study of the subject, and these men must be given exclusive jurisdiction.

Irrigation administration has thus far been hampered by the prevailing practice of leaving the final settlement of practically every question to the courts. While there are certain questions which must always be left to judicial settlement, we are leaving far too much to litigation at present. The party who files on a homestead must make his proof in a United States land office. $\mathrm{He}$ cannot go to the courts for a patent. If he could, demoralization in land matters would be prompt and certain. In the same way, to make administration of streams effective, those having charge of this administration must be given adequate authority. If parties can elect whether they will settle their rights in the courts or before an irrigation tribunal, the creation of the tribunal will be worse than useless. Suppose there are ten claims to water from a stream. If nine claimants elect to have rights settled before the irrigation tribunal and one goes into court, there will be two sets of 
rights and unending complications as a result. A double jurisdiction over streams is no more possible than is the operation of a railroad with two presidents to direct its policy.

In order to have a just determination of rights, it is necessary to have them based on a correct knowledge of physical facts. Before it can be settled how much water has been appropriated, it must be known how much water a stream carries. Before any one can decide how much water has been beneficially used, the location and extent of the land irrigated must be known and there must be an approximate determination of the duty of water. Before any rights to a stream are established, all the uses of water from it should be determined by some public authority and the results of these measurements given the widest publicity in order that all interested may know how much is being used and how much remains to be used hereafter. The need of this information is so obvious that it is difficult for those unfamiliar with the subject to credit the assertion that in all but four of the Western States this matter has been wholly neglected.

After rights are defined, they should be protected. This cannot be left to appropriators themselves. Peace and security can only be assured to the millions of irrigators, who are to fill Western valleys, by having such a system of administration as will assure each user of water that he will receive his just share of the supply, no 
matter how far from the mountain snows his farm may be situated.

Success in this administration requires that the valleys of rivers and their tributaries must be divided up into districts of convenient size, the boundaries of which shall be based on drainage lines. These districts should constitute separate independent political divisions of each arid State.

If possible, the limits of State and Federal jurisdiction should be more clearly defined. It has heretofore been assumed that the authority of each State in the disposal of the water-supply within its borders was unquestioned and supreme, and two of the States have constitutional provisions asserting absolute ownership of all water-supplies within their bounds. A recent decision of the United States circuit court holds this view to be erroneous, and in other litigation, the decisions have been of such a character as to give rise to grave uncertainty as to what is to be the ultimate settlement of this issue.

There is further need of legislation on this question because of the serious complications which have arisen from the absence of any national law or regulation concerning the division of water across State lines. There are many instances where one stream is a source of supply for irrigators in two or more States. It is beginning to happen that the perennial flow of these streams, which was first appropriated in the State along its lower course, has been utilized at a later period by 
irrigators in the State above. Neither of the States concerned possesses power to remedy the injury which results and each makes claim to all the water flowing upon its soil. Owing to each State having been left to legislate on this question independently of its neighbors, the water rights in adjacent States are in some instances as different in character as if these commonwealths were on opposite sides of the globe. The complications created by these differences aggravate the evils and render the adoption of regulations for the division of interstate supplies far more difficult. This does not mean, however, that a solution is impossible, but it does require that the means to be employed should receive early and careful study.

Thus far, rights to water in all of the Western States and Territories have been made free and perpetual, and it has been urged that the policy under which the natural flow of streams has been disposed of should be extended to the water stored in public reservoirs. Those who urge the adoption of this policy justify it on the ground that the results which will come from the cultivation of the soil thus rendered productive will more than justify the outlay. It is pointed out that the gov. ernment has constructed reservoirs at the head of the Mississippi for the benefit of navigation, and it is insisted that there are equal reasons for performing a like work on the headwaters of the Missouri for the benefit of agriculture; that since 
the first is done without charge, the other should be. There is, however, one feature in the improvement for the benefit of commerce which is lacking in the construction of irrigation works for the extension of agriculture. All who wish to navigate a river or harbor may do so, but all the owners of land along a stream cannot share in the waters of a reservoir. Hence, if the water from public works is made wholly free, the owners of arid land who are cut off from the supply will have just cause for complaint, as will those who build and maintain storage works at their own expense. The argument in favor of such liberality would have added weight if all the rights to water now recognized were attached to the land and limited to its need, but the fact that in a majority of the Western States rights to water are personal property and are being bought and sold like any other kinds of property, is not only an argument against such a policy in connection with government works but raises the question as to whether or not all the water used should not be charged for.

One of the great needs of Western irrigators today is more efficient public control of streams and better protection of existing rights, and the greatest obstacle to securing this is the difficulty of securing sufficient funds to pay for this service. It would be an immeasurable gain to the public if all the water diverted could be charged for and the money thus collected be used to pay for better administration. The collection of such 
rentals would also have an educational influence of no mean value. It would place public ownership of streams before irrigators in a form to be understood. At present, to the great body of water users, the doctrine of public ownership is a mere abstraction. Appropriations are made without regulation and streams are diverted without supervision, and those who use them believe that what they so completely control belongs to them. But if a rental were paid to the public, no matter how small, it would show that the public and not the appropriator was the owner of the stream.

The plan of charging a rental for the water furnished could also be made to work well in the operation of public reservoirs. These should not displace but supplement the use of water taken directly from the streams. When there is an abundance of water, the reservoir should not be drawn upon, but its water should be held until ditches cannot be filled from the natural flow. Under this plan an acre of land will be watered during part of the season from the stream and during the remainder from the reservoir.

No plan for doing this is so simple or promises to be so effective in promoting economy as to charge for the quantity received, making the rate for stored water higher than for the natural flow, and thus make the cost to irrigators an inducement for thrift and saving.

The time has also come for considering whether 
or not grants of water should be made perpetual. Some of the foremost irrigated countries of Europe treat these rights as franchises and limit their duration to fifty or ninety-nine years. Such franchises would serve every useful purpose of a grant in perpetuity and might save future generations from large outlays in the condemnation of vested rights, should such action be found desirable. The tendency in cities toward municipal ownership of public utilities will, it is believed, extend in time to the municipal ownership of canals and reservoirs, and the policy of cities in limiting franchises may well be extended to legislation controlling appropriations of the public waters. The liberality of the earlier years of this industry is only a reflection of the early policy of cities, where the grant of free and perpetual franchises was not looked upon with any particular disfavor. The objection to perpetual rights in streams has been well stated in the following extract from Baird Smith's "History of Irrigation in Italy":-

A grant in perpetuity of such a material as water, whose value must necessarily go on augmenting with the progress of agricultural irrigation, is an act of injustice toward the government. . . .

For there is no point better established by experience in northern Italy generally, and in Lombardy particularly, than this, that the selfishness of grantees in perpetuity of water has been one of the most serious obstacles to the development of irrigation. Acting on the principle that they had a right to do what they liked with their own, they were in the habit of suspending arbitrarily the supplies of water disposed 
of by them to other parties under subordinate grants, of increasing as they thought fit the prices to be paid, and, in a word, of pushing to its utmost limits the right of absolute property purchased by them from the State. But an agriculture founded on artificial irrigation cannot advance as it ought to do under such an arbitrary system.-(Vol. II, pp. I37 and I38.)

The holders of ancient grants in perpetuity have occasionally asserted an absolute right of property in the water thus granted to them, but the legal tribunals have invariably rejected such claims on the ground that the grants were made for the general good of the country as much as the special advantage of the grantees. - (Vol. II, p. 259.)

There is every reason to believe that far-reaching changes in the irrigation systems of the West must occur in the near future. The present conditions cannot continue. The growing demand for water for irrigation purposes, the greater needs of cities and towns for domestic uses, the growing value of water in the generation of power, are rendering it more and more desirable that there should be some simple and final method of determining and protecting rights to streams. Thus far, all these questions have been settled under State laws and by the decisions of State courts. Undoubtedly, there will be in the future a larger exercise of Federal authority in the division of streams across State lines, but this need not involve any interference with local customs and local regulations within a State. Where a stream flows from one State into another, the Federal authorities can determine how much of the water- 


\section{IRRIGATION INSTITUTIONS}

supply belongs to the lower State and may require the State officials to so regulate head-gates as to permit this volume to flow down. This can be done in such a way as to leave it to the State officials to determine which head-gates shall be closed and what rights shall be protected in the use of the water to which either the upper or lower State is entitled. It is in every way desirable that there should be no greater interference with local control than is absolutely necessary. The wide difference in local customs and local conditions renders it impossible that a general law should everywhere work equally well and makes it desirable that each State should develop along lines best suited to its environment. In most valleys the division of water among irrigators is as much a local matter as the municipal regulations of cities and towns. The people who live there understand their water-supply, the needs of the land, and the local peculiarities of soil and climate. It would be unscientific and in the highest degree unfortunate if the principle of local self-government, on which this nation is founded, and the opportunity to exercise self-reliance and self-control, which has done so much for its manhood in the past, should be taken away from the irrigators of the West by the transfer of the local regulation of streams to some centralized bureau. It is believed that Secretary Wilson of the United States Department of Agriculture in his last report outlined 
the policy which should govern future development when he said:-

Reform in irrigation laws will only be final and satisfactory when it comes through the enlightenment of the people most concerned. In a matter so vitally affecting the home as the control of the water-supply, no legislation will be effective which has not the sanction of the irrigators themselves.

As has been shown, the differences in State laws are fundamental. A national law would disturb local usages and customs to which communities are wedded and which irrigators understand. Notwithstanding the mistakes which have been made in the past, it is believed that framing irrigation laws should continue to be the work of State legislatures. Leaving it to the people of the several States to solve these issues is leaving it to those most interested in the success of this industry and hence to the highest intelligence which can be enlisted.

But the best use of Western resources requires more than a reform of water laws. Other questions besides the ownership and division of streams need the earnest and thoughtful consideration of all who are interested in the western third of this country. The speculative filings on public land should come to an end. The forests which clothe the mountain tops must be saved from destruction. Inroads by fire and axe have not only caused a wanton and needless waste of property of great value, but have lessened the available water-supply and seriously curtailed the number of acres irri- 
gated in many Western valleys. The decay of agriculture in southern Spain began with cutting the timber from the Pyrenees, and with the removal of the mountain forests of Palestine went not only the ruin of agriculture in that country, but the decadence of the nation itself. The future of the West will be largely influenced by measures taken to perpetuate the mountain forests. Only second in importance to the forests is the preservation of the scanty but nutritious grasses in the valleys. The importance of the grazing land as a factor in irrigation development ought not to be longer overlooked. Measures should be adopted which will unite the use of the grazing and irrigable lands and in this way help to extend the boundaries of the habitable area. The legislation of the last Congress should be supplemented by laws for better use of the grazing lands. The measure introduced in Congress by Senator F. E. Warren, of Wyoming, in I892, which provided for the union of land and water, for the classification of the public lands into irrigable, grazing, and forest areas through a comprehensive economic survey, and for the location of ditches according to a prearranged plan having for its object the most economical use of the water-supply would, if adopted, have saved to irrigators many water fronts which have now passed into the hands of speculators.

The West needs, as never before, to study methods of social organization and to develop 380 
plans for coöperation. The need of watering many farms from a common source, and of organizing communities for the distribution of water under fixed rules and discipline, makes irrigation a nursery of coöperation. Its influence has been manifest in the tendency of Western communities toward coöperative organizations of an industrial character, of which the fruit exchanges of California and the potato exchanges of Colorado are typical examples. That the principle of coöperation in irrigation is sound, is shown by the success of coöperative ditches, which are everywhere maintained with less friction and operated at less cost than are canals controlled by others than the owners of the irrigated land; but coöperation, in many instances, should be extended beyond the ditch to the control of the stream, and should be fostered by proper legislation. It is believed that the irrigation district acts of Colorado and Idaho furnish a safe working basis for the coöperative ownership and management of ditches, and that irrigation on many streams in these States will in time be organized in accordance with their provisions. These acts not only make new development possible, but provide a convenient means for the transfer of canals, built as corporation enterprises, to the ownership and control of the farmers who use them. The Colorado irrigation district act has been made use of in combining under one management a number of rival and conflicting appropriations from the same stream, with a 
lessening of friction between water users and greater economy in the use of water, and lessened cost in the management of ditches. The Wyoming law accepting the Carey grant makes coöperation obligatory. The canal must be owned and operated by the settlers who secure the lands below it. Every settler becomes a part owner in the canal and the water right attaches to the land, the canal being simply a carrier.

Heretofore, one of the evils of the irrigated home has been its isolation. The valleys of many streams are narrow. The broad areas which lie between are the home of cattle and sheep but not of man. The Anglo-Saxon thirst for land, and the opportunity to gratify it, has resulted in many instances in a wide separation between homes and in a loss to settlers of needed advantages in the way of schools, churches, and social life. The present tendency is in the other direction. In the older settled irrigated districts, the large estates are being broken up and land is being divided up into small holdings. This is so because irrigation is best suited to intensive farming, to the cultivation of crops which need the intelligence and personal interest of the man who is tilling his own soil and working in his own behalf.

In some parts of the West the European custom of grouping homes in farm villages, which was brought to this country by the emigrants to Utah, has grown in popular favor. Where farmers live in villages, they are able to realize a happy 382 
combination of town and country life, and to dwell under conditions which are favorable to a growth of the best forms of civilization. The realization of this is well worth the struggle which is now going on for the reform of our land and water laws - a struggle which will impose high demands upon our statesmanship and call for the exercise of an unselfish patriotism. 



\section{INDEX}

Acre-foot, measurement by, Iog, Arkansas Valley Canal Company, II8-I2I.

Adams, Frank, ix.

Adjudication of water rights, 68, 80-82, 229-233.

Colorado, I47-I59.

Kansas, 290.

Montana, 302-308.

Utah, 225-227.

Wyoming, 250-266.

Administration of streams, Colorado, $\mathbf{1}_{59-167 .}$

Agricultural Department, work of, viii.

Ahtanum Creek, Washington, 3 I6.

Alta Land Co. $v$. Hancock, I94.

Altitude, influence of, 7 .

American Fork River, Utah, division of, 233.

Anaheim, California, colony, 45.

Annual water rentals, 89-92.

Appropriation :

California law, I87-188.

Doctrine of, 60-87.

Notices of, 73-78.

Utah law, 222-224.

Arid region :

Possibilities, 2.

Topography, 4-5.

Arizona, 275-285.

Agriculture in, 15 .

Cementing materials in water, I25.

Evaporation, I27.

Laws, 276-278.

Posting notices, 68.

Storage, 283-284.

Arkansas River, I53, I76-I77, 289,

320, 335-343, 354-355.

$2 \mathrm{C}$

I77.

Baring Brothers, 344.

Bear Creek, Colorado, rights to, I5I.

Bear River, 242, 330.

Bear River Canal, Utah, 20, 56, 244-245.

Beneficial use as basis of right, 67 .

Big Horn River, 355.

Big Thompson River, Colorado, I5I, I72.

Bitter Root Valley, Montana, 298.

Black Hills, irrigation, 296.

Board of control, Wyoming, 252266.

Boggs, E. M., 75 .

Boise River, Idaho, 76, 3 Iо.

Bond, J. L., I46.

Boulder, Colo., 45.

Boulder Creek, Colo., I5I.

Bruneau River, Nevada, 312.

Cache Creek, California, litigation over rights, I98-202.

Cache la Poudre River, Colorado,

I44, I45, I49, I5I, I72, 355 .

California, 180-219.

Acquirement of land by irrigation companies, 24.

Climate, 180-182.

Early irrigation, 45 .

Future development, 217-219.

Irrigating season, $\mathbf{1 2 0}$.

Irrigation district law, 209-213.

Irrigation statistics, 183 .

Land values, $21,184$. 


\section{INDEX}

California (cont.) :

Litigation, 197-209.

Miner's inch, 108.

Posting notices, 68.

Rates for water, 214-2I6.

Records of water rights, $188-190$.

Results of irrigation, 48.

Right of appropriation, I87-188, I90, I95, 196.

Rights to underground water, I90-192.

Riparian rights, I92-I96.

Value of water, 184.

Water-right agreements, 202203.

Water-right records, 73.

Wheat farming, 185-186.

California Water and Forest Association, 218.

Calloway Canal, California, 186.

Canada :

Northwest Irrigation Act, 209, 326-327.

Perpetual licenses, 62 .

Canal organization and management, Utah, 233-239.

Carey act, 24-27, 99, 272-274, 345, 382.

Carlsbad, New Mexico, 286.

Carson River, Nevada, 312.

Catlin Canal Company, I77.

Cementing canals, 125 .

Center Creek Irrigation Company

v. Thomas, 229.

Central Canal, California, 350.

Chittenden, H. M., report on reservoirs, I37.

City Creek, Utah, value of rights, 86.

Clark $v$. Cambridge and Arapahoe Irrigation and Improvement Company, 294.

Clear Creek, Colorado, rights to, I5I.

Climate, 3-4.

Effect of irrigation, 339-34I.

Code, W. H., ix.
Colorado, 143-179.

Acquirement of land by irrigation companies, 24.

Adjudication of water rights, I46-159.

Administration of streams, 159I67.

Ancient irrigation, 4I.

Constitutional provisions, I44.

Early irrigation, I43-I 44 .

Exchange of water, 163 .

Filing claims, 68 .

Fixing rates for water, I68.

History of water laws, I44-I46.

Irrigated area, 349.

Irrigation districts, I79.

Law requiring measuring devices, II2-II3.

Laws of, 83, 144, 208-209.

Leasing State lands, 39.

Loans of appropriations, I75I79.

Records of water rights, I44.

Reservoirs, I69-I73, 356.

Results of irrigation, 48.

Sale of water rights, $173^{-1} 75$.

State engineer, II2, 159, 164-I65.

Superintendents' duties, 165.

Water commissioners, I45, I57I58, I6I-I64.

Water districts, I59-I6I.

Water divisions, I60-I6r.

Water-right contracts, I2I.

Colorado River, 46.

Columbia River, 5, 315.

Construction of irrigation works, 48-50.

Continuous flow, rights to, $8 \mathrm{r}$.

Contract water rights, 88-99.

Coöperation, need of, $3^{80-382 .}$

Coöperative canals, 44-45, 50-57, 98-99.

Corporation canals, 57-59.

Cost of water, I29-I30.

Crawford Company v. Hathaway, 294.

Crisis of 1893 , influence of, 344-345. 
Crocker-Huffman Canal, California, 186.

Cubic foot per second, measurement by, Ior, IO7-IO9, Ir8I2I.

Deseret News, 22r.

Deseret, State of, 22I.

Desert Land Law, I6-I7.

Abuses under, 21-22, 35 .

Dews, 34I.

Distribution of water :

Continuous flow, 230-23r.

Nebraska, 294.

Rotation, I33, I44-145.

Utah, 229-232.

Wyoming, 270-271.

Distribution of stored water, $35^{8-}$ 360.

Dobson, Adna, ix.

Drainage, Utah, 243.

Dry farming, Montana, 298.

Duty of water, II6-I42.

Assumed in decrees, Colorado, I53-I 54 .

Nebraska, 293.

Necessity for knowledge of, $37 \mathrm{I}$. Wyoming, 27r.

East Canyon Creek Reservoir, Utah, 243.

Elliott, Judge, 156 .

Europe, water rights attached to land, 84 .

Evaporation, loss of water by, I27, I36.

Exchange of water, Colorado, 163.

Fencing the public lands, 28-35.

Field, J. E., ix.

Fixing rates, California, 214-216.

Foote, Mary Hallock, 3 Io.

Forest preservation, need of, 379380.

Fort Collins, Colorado, 45, I44.

Fortier, S., ix.

Seepage measurements by, 125I26.
Fort Lyons Canal Company, 177.

Franchises for water, 375-377.

Future development, 344-383.

Gage Canal, California, system of distribution, I33.

Gallatin, Albert, report on public lands, $\mathbf{I} 4$.

Gallatin Valley, Montana, 298.

Gila River, Arizona, 284.

Grand River, 245, 353.

Grazing lands, vii-viii.

Conflicts over, 29-33.

Importance of, 7 .

Leasing, 33, 38-40.

Management of, 27-40.

Montana, 297.

Need of reforms, 380 .

Overstocking, 35,38 .

Greeley, Colorado, 44-45, I44, I45.

Greene, J. S., ix, 176.

Green River, 245, 353.

Gould $v$. Stafford, I94.

Government construction of irrigation works, $348-383$.

Hamilton, Alexander, land laws proposed by, I4.

Harte, Bret, 185 .

Hathmati Canal, losses from, I24.

Hemet Reservoir, California, I95.

High Line Canal, Colorado, ${ }^{8} 8$.

History of irrigation, 4I-59.

Homestead law, I4-I6.

Abuses under, 20-2I, 35-38.

Honey Lake Valley, California, claims to water, 190.

Howell $v$. Johnson, 334-335.

Humboldt River, Nevada, 312, 363.

Idaho, 309-3I2.

Development under Carey Act, 25.

Early irrigation, 45 .

Irrigated area, 349 .

Posting notices, 68.

State engineer, 3 I $\mathrm{r}$. 


\section{IN DEX}

Idado (cont.) :

Tax on sheep, 34 .

Inch, measurement by, Io2-IO7, 108, I18-121.

Indians, irrigation by, 4I.

Interior Department, work of, viii. Interstate rights, 328-343, 372-373, 377-378.

Irrigable lands :

Extent, 5-6.

Location, 362-363.

Irrigable public lands, 353 .

Irrigating season :

Diagram showing, IIg.

Length, I20.

Irrigating stream, Io9-III, 237.

Irrigation :

Effect on climate, 339-34I.

Extent and results, 46-48.

Influence on other industries, 9Io.

Irrigation districts, $345,38 \mathrm{r}-382$.

California, 209-2I3.

Colorado, 179.

Utah, 234.

Irrigation Investigations, U.S. Department of Agriculture, 8I, I21, I22, 138, 347.

Italy, Baird Smith's history of irrigation, 376-377.

Water ownership in, 62,365 .

Jackson Lake, 9.

Jamda Canal, Bombay, losses from, I24.

Johnston, C. T., ix.

Jordan River, Utah, 224-226.

Division of water, 239.

Extension of use, 24I-242.

Water rights, 226-227.

Kansas, 288-290.

Irrigation laws, 322.

Irrigation works, 336 .

Posting notices, 68.

Riparian rights, 289.

Water bailiffs, 290 .

v. Colorado, 335-343.
Kibbey, Judge, 279.

King's River, California, flow, Igo.

Lacey, J. F., bill for leasing public lands, 40.

Laguna Canal Company, I77.

Lake Tahoe, 329.

Land laws, effect on development, I5-23, 35I.

Larimer and Weld Canal, Colorado, 50 .

Laws :

Arizona, 276-278.

California, 187-188.

Character, vi.

Colorado, 83, I44, 208-209.

Kansas, 322.

Montana, 299.

Nebraska, 82, 167, 29I-292, 366.

Nevada, 3I2-3I4.

South Dakota, 326.

Utah, II2, 220-224.

Wyoming, 82, 83, 167, 209, 248$252,366-367$.

For disposal of public lands, r3- $^{-}$ 23.

Leasing public lands, 33, 39-40.

Leasing railroad lands, 40.

Leasing State lands, 39-40.

Lesser Snake River, 330.

Licenses to use water, $62,63,82$.

Litigation:

California, 197-209.

Effect on development, 346, 35035 I.

Live stock associations, 29.

Logan River, Utah, storage possi-

bilities, I39-I4I, 24r, 242.

Longmont, Colorado, 45, 144.

Los Angeles River, California:

Claims to, 75 .

Litigation over rights to, I97-I98.

Losses from seepage and evaporation, 123-127, 136.

Loup River, Nebraska, 293.

Loveland, Colorado, 45.

Lux $v$. Haggin, 193, $194,196$. 
McCune, A. J., 158.

McFadden $v$. Supervisors, 216 .

Marsh, G. P., 367.

Measurement of water, IO0-II5.

Methods of irrigating, 48-50.

Mexican land grants, 60.

Middle Creek, Montana, rights to, 304-308.

Military bounty lands, area of, I3.

Milk River, Montana, 297.

Mills, F. J., opinion on necessity for storage, 138 .

Miner's inch, value in cubic feet per second, I08.

Missouri River, 5, 46, 71, 297, 299, 30I, 353.

Mojave Desert, 2.

Montana, 297-308.

Adjudication of water rights, 302-308.

Dry farming, 298.

Early irrigation, $45-46$.

Grazing lands, 297.

Irrigated area, 298.

Irrigating season, 120.

Laws, 299.

Leasing state lands, 39 .

Nature of water rights, 300 .

Posting notices, 68.

Water-right records, 301 .

Mormons, 42-44, 55, 83, 233, 309.

Musselshell River, 3 ㅇ.

Navigation rights, 332-333.

Nebraska, 290-295.

Acquirement of water rights, 82.

Distribution of water, 294.

Laws, 82, I67, 29I-292, 366-367.

Permits for water, 68.

Water commissioners, 294.

Nesters' war, 3r.

Nettleton, E. S., ix, I21, 166.

Nevada, 3I2-3I4.

Early irrigation, 45-46.

Evaporation, I27.

Irrigation laws, 312-3I4.

Tax on sheep, 34 .
New Mexico, 285-288.

Ancient irrigation, 4I.

New South Wales, riparian rights, 328.

Norris, Frank, 185 .

North Piatte River, 7I, 33I-332, 355.

Northwest Irrigation Act, Canada, 209.

Ogden River, Utah, storage, 242.

Oregon, 3I7-3I8.

Organization and management of canal companies, Utah, 233239.

Overland Trail, irrigation along, 44, I43.

Owyhee River, $3^{\text {I } 2 .}$

Payette River, Idaho, 3 ro.

Pecos River, 8, 285-286, 357.

Perpetual rights, sale of, 93-98.

Platte River, 293, 363.

Posting notices of appropriations, 68-74.

Powell, J. W., 347.

Preëmption law, I4, I6, I8.

Preferred uses of water, 66.

Priority :

Doctrine of, 65.

Wyoming, 249.

Private property in water, 365 .

Pro-rating, 96.

Provo River, division of, 229-230.

Public construction of irrigation works, 58, 234-235.

Public control of streams, $82, \mathrm{I} 45$, 293, 369-375.

Public domain :

Area of, 13.

Disposal of, 13-23.

Fencing, 35 .

Irrigable, 353.

Pumping water for irrigation, I4I, r91-192.

Quarantine laws, 34 . 
Railroad land grants, area of, 13. Railroad lands :

Leasing, 40.

Purchase of, 24.

Rainbelt theory, 290.

Range live stock business, collapse, $35-36$.

Rates for water, 90-92.

California, 214-2I6.

Colorado, $\mathrm{r} 68$.

Records of water rights, $67-80$.

California, I88-I90.

Montana, 301.

Utah, 223.

Relation, doctrine of, 65-66.

Reservoirs :

Colorado, I69-173, 356.

Necessity for, 137, I4I.

Pecos River, New Mexico, 287.

Profits from, 243 .

Public, 358-362.

Public aid for, in New Mexico, 287.

Silting, 9.

Utah, 357 .

Value of, 357 .

Wyoming, 356.

Return, seepage, 34I.

Returns from irrigation, 49.

Rio Grande, 8, 285, 286.

Rio Grande Valley, early irrigation, 4I.

Riparian rights, 62, 319-328, 364 .

California, 192-I96.

Kansas, 289.

Nebraska, 293-294.

Washington, 3I6-3I7.

Riverside, California, colony, 45.

Rogers, Platt, I56.

Roosevelt, Theodore, 360, 367 .

Ross, D. W., ix, I30-13r, 3rI.

Ross, Erskine M., I93, 215.

Rotation, influence on duty, 133-136.

Rustling, 32.

Sacramento River, 4.

St. Vrain Creek, Colorado, rights to, $15 \mathrm{I}$.
Sale of water:

Colorado, I73-I75.

Montana, 302.

Salmon River, Nevada, 3 I2.

Salton Desert, 7.

Salt River, Arizona :

Claims to, 277.

Division of, 279-281, 284.

Practices along, 137 .

Salt River Valley, Arizona, 2.

Ancient irrigation, 4I.

Irrigated area, 349.

Pumping, I4I.

San Joaquin River, California, 74, I90.

Santa Clara Valley, California, pumping, I4I, Ig2.

Seepage :

Defined, I24.

Loss of water by, I23-126, 136 .

Methods of preventing, 125-126.

Return to streams, 34I.

Sevier River, Utah, $242,246$.

Sheep on the public lands, 29-30, 33.

Shoshone Falls, Io.

Smith, Baird, "Irrigation in Italy," 376-377.

Smythe, William E., ix, 18, 189, 274.

Snake River, 4, 9, 46, 353.

Soldiers' widows, homestead filings, 36.

Soule, Frank, 74.

South Dakota, 295-296.

Laws, 326.

Souther v. San Diego Flume Company, 2I6.

South Platte River, 7I, 88, I43, I45, I5I.

Spain, 380.

Spanish Fork River, Utah, rights to, 226 .

Spanish land grants, 24-60.

Sprague $v$. Heard, I94.

State engineer:

Colorado, II2, I59, I64-I65. 


\section{IN DEX}

State engineer (cont.):

Idaho, 3 II.

South Dakota, 296.

Utah, 239-240.

Wyoming, I12, 26I, 268.

State lands, influence on irrigation development, 23-24.

States, lands granted to, I3.

Statistics, lack of, 46-47.

Storage :

Arizona, 283-284.

Effect on flow of streams, 342 .

Necessity for, 8, 354-356.

New Mexico, 287.

Rights for, in Wyoming, 272.

Utah, 24I-245.

Surnyside Canal, Washington, 58.

Swamp land laws, area granted under, I3.

Sweetwater reservoir, California, 195 .

Taxing flocks, 34 .

Teele, R. P., ix.

Texas:

Filing claims, 68.

Land laws, 15 .

Timber culture law :

Provisions, I6.

Repeal, I8.

Truckee River, 312, 329, 363 .

True, A. C., ix.

Turlock Canal, California, 213.

Twenty-four hour inch, I33-r34.

Twin Lakes Company, I77.

Underground rivers, 6 .

Underground water:

Rights in California, I9O-I92.

Rights in Kansas, 289.

Union Colony, 44-45, 52-54, $5^{8}$.

U.S. Geological Survey, stream measurements by, 138 .

United States $v$. Rio Grande Dam and Irrigation Company, 333.
Utah, 220-246.

Adjudication of water rights, 225227.

Bear River Canal, 244-245.

Canal organization and management, 233-239.

Classification of rights, 66 .

Controversies over water rights, 232-233.

Coöperative ditches, 55-56.

Division of water, 229-232.

Drainage, 243.

Early irrigation, 42-44.

Early laws, 220-224.

Future development, 24I-246.

Grand River, 245.

Green River, 245.

Irrigation districts, 234 .

Law governing measurement of water, $\mathbf{1} 12$.

Leasing State lands, 40.

Nature of water rights, 227-232.

Posting notices, 68.

Primary rights, 228.

Reservoirs, 357.

Secondary rights, 228.

Sevier River, 246.

State engineer, 239-240, 244 .

Storage, 24I-245.

Water commissioners, 224, 240.

Water power, 226.

Utah Lake, 225, 24I.

Value of water, California, I84.

Verde River, Arizona, rights to the, 278.

Victoria, Australia, report on watersupply, 367 .

riparian rights, 328 .

Walker River, Nevada, 3 I2.

Warren, F. E., 380.

Washington, 3I4-3I6.

Posting notices, 68 .

Water, value of, 8.

Water bailiffs, Kansas, 290. 


\section{IN DEX}

Water commissioners :

Arizona, 279.

Colorado, 84 , I55, I57-I58, I6II64.

Duties of, 84 .

Nebraska, 294.

Utah, 224, 240.

Wyoming, 248, 270-27r.

Water fronts, control of, 35-37.

Water-power :

Development of, Io.

Rights for, 226-227.

Water registers, II2-I I5.

Water-right contracts, 88-99.

Arizona, 28I-282.

Colorado, I67-168.

Duty assumed in, I2I, I36, I54.

Effect on development, $35 \mathrm{I}$.

Influence on duty, I28, I3I.

Terms of, $95-98$.

Water-right records, 69-8o.

California, I88-I9o.

Montana, 301.

Utah, 223.

Water rights :

Acquirement, 60-87.

Adjudication, 68, 80-82.

Arizona, 276-284.

Attached to land, 22, 23, 25, 83,

84,89, I96, 3II, 347, 366-368.

California, 188 .

Acquirement, I88.

Agreements, 202-203.

Nature, 2I5.

Colorado :

Adjudication, I47-I59.

Loans, I75-I79.

Nature, I52.

Sale, I73-I75.

Europe, 84 .

Interstate, 328, 377-378.

Kansas, 290.

Montana, 300.

Nature of, vi-vii, 82-87, 364-369.
Water rights (cont.) :

Nebraska, 29I.

New Mexico, 288.

Sale of, 86.

Utah :

Acquirement, 220-224.

Nature, 227-232.

Value of, 86-87.

Wyoming, 82, 253, 266-269.

Weber River, Utah, 70, 242.

Wichita River, 8.

Wilson, James, 378.

Wilson, J. M., ix, 20I.

Works, John D., I94.

Wright law, California, 209-2I3, 345 .

Wyoming, 247-274.

Acquirement of water rights, 82 , 253, 266-269.

Adjudication of water rights by board of control, 253-266.

Board of control, 252-266.

Carey law, 25, 272-274.

Distribution of water, 270-27r.

Early irrigation, 45-46.

Evaporation, 247-248.

Laws, 82, 83, 167, 209, 248-252, $366-367$.

Leasing State lands, 39-40.

Priority, 249.

Reservoirs, 356.

State engineer, II2, 26I, 268.

Storage rights, 272.

Water commissioners, 248, 270$27 \mathrm{I}$.

Wyoming Development Company, 20, $5^{8}$.

Yakima River, Washington, 3I5, $3^{6} 3$.

Yellowstone Lake, 9, 299.

Yellowstone River, 4, 9, 70, 297, 30I, 353,363 .

Young, Brigham, 55. 


\section{THE CITIZEN'S LIBRARY OF ECOINOMICS, POLITICS, AND SOCIOLOGY}

UNDER THE GENERAL EDITORSHIP OF

RICHARD T. ELY, Ph.D., LL.D.

Director of the School of Economics and Political Science; Professor of Political Economy at the University of Wisconsin

12mo. Half Leather. \$1.25, net, each

Monopolies and Trusts. By Richard T. Ely, Ph.D., LL.D.

"It is admirable. It is the soundest contribution on the subject that has appeared." - Professor John R. Commons.

"By all odds the best written of Professor Ely's work." - Professor Simon N. Patten, University of Pennsylvania.

Outlines of Economics. By Richard T. Ely, Ph.D., LL.D., author of "Monopolies and Trusts," etc.

The Economics of Distribution. By JoHn A. Hobson, author of "The Evolution of Modern Capitalism," etc.

World Politics. By Paul S. Reinsch, Ph.D., LL.B., Assistant Professor of Political Science, University of Wisconsin.

Economic Crises. By EDward D. Jones, Ph.D., Instructor in Economics and Statistics, University of Wisconsin.

Government in Switzerland. By John Martin Vincent, Ph.D., Associate Professor of History, Johns Hopkins University.

Political Parties in the United States, 1846=1861. By Jesse Macy, LL.D., Professor of Political Science in Iowa College.

Essays on the Monetary History of the United States. By Charles J. Bullock, Ph.D., Assistant Professor of Economics, Williams College.

Social Control: A Survey of the Foundations of Order.

By Edward Alsworth Ross, Ph.D. 


\section{The Citizen's Library of Economics, Politics, and Sociology}

Colonial Government. By Paul S. ReInsch, Ph.D., LL.B., Assistant Professor of Political Science in the University of Wisconsin. Cloth, I 2mo. Now ready. \$1.25 net.

The main divisions of the book are as follows: I. The Extant and Component Parts of Existing Colonial Empires. 2. Motives and Methods of Colonization. 3. Forms of Colonial Government. 4. Relations between the Mother Country and the Colonies. 5. Internal Government of the Colonies. 6. The Ethical Elements in Colonial Politics. 7. The Special Colonial Problems of the United States.

Democracy and Social Ethics. By JANE AdDAMs, head of " Hull

House," Chicago; joint author of "Philanthropy and Social Progress." Cloth, 12mo. Now ready. \$1.25 net.

Miss Addams's work as head of " Hull House" is known to all persons who are interested in social amelioration, and her writings in the best periodical literature have produced the impression that they proceed from a personality equally strong and gracious. This work will show the profound insight into social conditions and the practical wisdom which we all expect from Miss Addams. As the title implies, it will be occupied with the reciprocal relations of ethical progress and the growth of democratic thought, sentiment, and institutions.

Municipal Engineering and Sanitation. By M. N. BAKer, Ph.B., Associate Editor of Engineering Nezes; Editor of A Manual of American Water Works. Cloth, 12mo. \$1.25 net.

[Now ready.]

This work will discuss in a general introduction the city and its needs, and the plan of the city, and then pass on to such practical questions as ways and means of communication, municipal supplies, collection and disposal of wastes, recreation and art, administration, finance, and public policy. Mr. Baker's work on the Engineer. ing News and the annual Manual of American Water Works has made him known as one of the leading authorities on all questions of municipal policy. He has the important advantage of combining the technical knowledge of the engineer with long familiarity with economic discussions; and it is expected that this volume will appeal to all classes in any way concerned in municipal affairs.

American Municipal Progress. By Charles Zueblin, B.D., Associate Professor of Sociology in the University of Chicago. Cloth, 12mo. Now ready. \$1.25 net.

Professor Zueblin is well known as one of the most successful University extension lecturers of the country, and his favorite theme in recent years has been municipal progress. In the preparation of this work, he has repeatedly conducted personal investigations into the social life of the leading cities of Europe, especially England. and the United States. This work combines thoroughness with a popular and pleasing style. It takes up the problem of the so-called public utilities, public schools, libraries, children's playgrounds, public baths, public gymnasiums, etc. All these questions are discussed from the standpoint of public welfare.

\section{IN PREPARATION FOR EARLY ISSUE}

Custom and Competition. By RICHARD T. ELY, LI.D., Professor of Political Economy and Director of the School of Economics and Political Science in the University of Wisconsin; author of "Monopolies and Trusts," President of the American Economic Association, etc. Cloth, r2mo.

This volume will follow naturally Professor Ely's work, "Monopolies and Trusts." Custom is first considered in its most general economic aspects. Its influence in early stages of society is described and its evolution in subsequent stages is traced. Topics treated under Custom include the Rent of Land and Custom, Interest and Custom, The Remuneration of Personal Services and Custom, Custom and Commerce. 


sre nem 


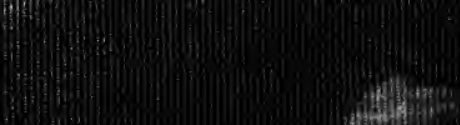
3fing

(4)

fing 